Florida International University

FIU Digital Commons

3-21-2019

\title{
National Sovereignty and the Mexicanization of the Compañía Minera de Cananea, 1971 to 1989
}

Doyle Lawrence Perdue

Florida International University, dperd010@fiu.edu

Follow this and additional works at: https://digitalcommons.fiu.edu/etd

Part of the Latin American History Commons

\section{Recommended Citation}

Perdue, Doyle Lawrence, "National Sovereignty and the Mexicanization of the Compañía Minera de Cananea, 1971 to 1989" (2019). FIU Electronic Theses and Dissertations. 4046.

https://digitalcommons.fiu.edu/etd/4046

This work is brought to you for free and open access by the University Graduate School at FIU Digital Commons. It has been accepted for inclusion in FIU Electronic Theses and Dissertations by an authorized administrator of FIU Digital Commons. For more information, please contact dcc@fiu.edu. 


\title{
FLORIDA INTERNATIONAL UNIVERSITY
}

Miami, Florida

NATIONAL SOVEREIGNTY AND THE MEXICANIZATION OF THE COMPAÑÍA MINERA DE CANANEA, 1971 TO 1989

\author{
A dissertation submitted in partial fulfillment of \\ the requirements for the degree of \\ DOCTOR OF PHILOSOPHY \\ in \\ HISTORY \\ by
}

Doyle L. Perdue

2019 
To: Dean John F. Stack, Jr.

Steven J. Green School of International and Public Affairs

This dissertation, written by Doyle L. Perdue, and entitled National Sovereignty and the Mexicanization of the Compañía Minera de Cananea, 1971 to 1989, having been approved in respect to style and intellectual content, is referred to you for judgment.

We have read this dissertation and recommend that it be approved.

$\begin{array}{r}\hline \text { Kenneth Lipartito } \\ \hline \text { Bianca Premo } \\ \hline \text { Gill Hollander } \\ \hline \text { Victor Uribe, Major Professor }\end{array}$

Date of Defense: March 21, 2019

The dissertation of Doyle L. Perdue is approved.

Dean John Stack

Green School of International and Public Affairs

Andrés G. Gil

Vice President for Research and Economic Development and Dean of the University Graduate School

Florida International University, 2019 
(C) Copyright 2019 by Doyle L. Perdue

All rights reserved. 


\section{DEDICATION}

To my wife, Liz

my father, Doyle C. Perdue

and the family of Carlos Inclán Fuentes. 


\section{ACKNOWLEDGMENTS}

Successful scholarship rests on the foundation of those who have come before. It is truly impossible to adequately thank all who have helped me along the way. First and foremost, I thank Dr. Victor Uribe whose critiques and insights have been invaluable and have helped me to be a better scholar.

I am grateful to the institutional resources provided by Florida International University, particularly the Tinker Research Grant and Dissertation Year Fellowship.

I am most indebted to Carlos Inclán Fuentes and his family. Carlos taught me how to find and navigate the various archives in Mexico City. His family provided shelter, food, and friendship, and taught me to take myself less seriously, giving me the nickname "El Imperio." With them, I learned that the histories and futures of our two countries are truly inseparable. 
ABSTRACT OF THE DISSERTATION

NATIONAL SOVEREIGNTY AND THE MEXICANIZATION OF THE COMPAÑÍA

MINERA DE CANANEA, 1971 TO 1989

by

Doyle L. Perdue

Florida International University, 2019

Miami, Florida

Professor Victor Uribe, Major Professor

This dissertation argues that the Mexicanization of the Compañía Minera de Cananea in 1971 represented the strongest assertion of national sovereignty over Mexican mineral resources after more than 400 years of foreign control. In contrast to the nationalization of oil in 1938, however, this emerged as a conservative and moderate effort. The U.S.-based Anaconda Copper Company retained $49 \%$ of the company's ownership after selling $51 \%$ of the company to a combination of public and private interests in Mexico. This strategy represented the triumph of conservative forces, whose legitimacy rested on popular appeals to the Mexican Revolution, except transforming it into an instrument to achieve the goals of the new post-revolutionary elite.

The study uses the approach of cultural history to examine the contours of economic life. As such, the concept of national sovereignty illuminates changing discourses regarding the character of work, nature, and the organization of Mexican society and politics. In its original version, national sovereignty was integral to an economic paradigm whereby the possession, control, and 
exploitation of natural resources by the Mexican nation were to benefit the Mexican people. The revolutionary Constitution of 1917 divided labor and natural resources and made it so that the working class could be controlled and deployed according to national interests defined by elites.

Originating in a major strike in 1906, the myth of Cananea created an association between the working class, the Mexican nation, and the Mexican Revolution, which later provided legitimacy to the elite project of economic nationalism. After 1938, nationalist policy no longer advanced the social and economic well-being of the Mexican people overall but rather the private interests of elites. Mexicanization reduced the foreign control of mineral resources and introduced the private sector into the industry, but its failure to improve outcomes for Cananea's mineworkers frayed the bonds of the working class and the Mexican nation. The efforts of the Carlos Salinas administration to privatize the company in August 1989, further weakened such bonds. Salinas renegotiated the meanings of national sovereignty, deconstructing the broad framework of labor, the nation, and the Mexican Revolution established in the myth of Cananea. 


\section{TABLE OF CONTENTS}

CHAPTER

PAGE

INTRODUCTION

CHAPTER I. The Myths of Cananea: Labor, Nation, and the Mexican

Revolution .26

CHAPTER II. The Mexicanization of Mining Law, 1961 59

CHAPTER III. The Mexicanization of the Compañía Minera de Cananea, 1971 104

CHAPTER IV. The Compañía Minera de Cananea, 1971-1989 143

CHAPTER V. The Privatization of the Compañía Minera de Cananea,1989 189

CONCLUSION. 233

REFERENCES 244

VITA. 273 


\section{INTRODUCTION}

This dissertation examines the Mexicanization of the Compañía Minera de Cananea in 1971. According to its promoters, this policy and its implementation represented the strongest effort in the history of Mexico to assert national sovereignty over its mineral resources. This had been an effort five hundred years in the making. Since the arrival of Spanish conquistadors, the history of Mexico has been synonymous with the exploitation of its mineral resources by foreign powers. Neither the achievement of independence in 1821 nor the Mexican Revolution in 1910 succeeded at changing this situation. It was not until President Adolfo López Mateos signed the policy of Mexicanization into law in 1961 that Mexico begun to gain control of its mineral resources.

A fair number of Mexicans celebrated the process of Mexicanization of the Compañía Minera de Cananea in 1971 as an achievement of national sovereignty and a fulfillment of the Mexican Revolution. The revolution had established an ideology that legitimized a strong interventionist role by the state in the Mexican economy, for the purpose of advancing the social well-being of the Mexican people. This aspiration had its clearest expression when President Lázaro Cárdenas nationalized the oil industry in 1938. After decades of foreign ownership, this act eliminated all foreign participation and brought the industry under the direct management and administration by the Mexican state. The Mexicanization of the mining industry differed in significant ways.

While the nationalization of the oil industry represented the apex of the Mexican Revolution, it also signaled its decline. This revolutionary act unleashed 
a conservative reaction that fundamentally altered the nature of Mexico's political culture, bringing the end of the revolution according to several observers. Nonetheless, thereafter the Revolution remained the basis for a series of institutional changes aimed at achieving political legitimacy, economic development, and social cohesion. Yet, at the same time it was being institutionalized the Mexican Revolution became increasingly superficial. Instead of a motivating force for the social development and popular aspirations of the Mexican people, the Revolution became an instrument to achieve the goals envisioned by a new post-revolutionary elite. The Mexicanization of the mining industry, then, emerges within this context of revolutionary continuity and reactionary change. No case epitomizes this paradox more than the Mexicanization of the Compañía Minera de Cananea.

The history of the Mexicanization of the Compañía Minera de Cananea provides an ideal case to examine the negotiation of revolutionary ideals and to show the reality behind them. Located in the northwestern state of Sonora, Cananea gained historical relevance after American soldiers repressed a labor strike in 1906. This event became the foundational myth that joined the labor movement to both the Mexican nation and the Mexican Revolution. Over six decades later, the Compañía Minera de Cananea underwent the process of Mexicanization when the American-owned Anaconda Copper Company sold $51 \%$ of its shares to public and private Mexican interests. This process represented a rather moderate and conservative measure, yet its promoters presented it as an achievement of total national sovereignty. 
As this dissertation will establish, this maneuver ultimately represented the triumph, after 1938, of conservative forces whose legitimacy rested on popular appeals to the Mexican Revolution. Instead of advancing the well-being of the Mexican people, state intervention had become an instrument to advance elite interests by ending the monopoliziation of mineral resources in the hands of foreign owners and permitting the capital accumulation of mineral resources. Since the nationalization of the oil industry by President Lázaro Cárdenas, the achievement of sovereignty over natural resources was presented as a popular cause of the working class. The Mexicanization of the Compañía Minera de Cananea, however, demonstrated this to be a fiction. The optimism of government officials throughout the 1970 s contrasted sharply with the enduring grievances experienced by the mineworkers who felt nothing had changed. Clearly, national sovereignty possessed different meanings and implications depending on one's social class and occupation. Cananea's mineworkers believed that national sovereignty meant their sovereignty and that it would bring them direct benefits through greater control of their financial resources and their work activities. When these expectations failed to materialize, workers' identification with the Mexican nation weakened and they began to take matters into their own hands, reversing the decades-long pact between labor and the Mexican state. 


\section{Historiography}

The Mexicanization of the mining industry has received limited attention from scholars. Works dedicated to this topic include one article, "Mexicanization, Privatization, and Large Mining Capital in Mexico" by Raúl Delgado Wise and Rubén Del Pozo Mendoza, ${ }^{1}$ and a collection of essays, Cananea: tradición y modernidad en una mina histórica, edited by Oscar F. Contreras Montellano. ${ }^{2}$ The most prolific author has been Juan Luis Sariego who has authored and coauthored the most useful works on the subject, including El estado y la minería mexicana: política, trabajo y sociedad durante el siglo xx $(1988)^{3}$ and Enclaves y minerales en el norte de México. Historia social de los mineros de Cananea y Nueva Rosita, 1900-1970 (1988). ${ }^{4}$

Overall, these works present the Mexicanization of the mining industry as an achievement of national sovereignty with respect to mineral resources. ${ }^{5}$ On the nature of this policy, Delgado Wise and Mendoza have argued that the policy

\footnotetext{
${ }^{1}$ Raúl Delgado Wise and Rubén Del Pozo Mendoza, "Mexicanization, Privatization, and Large Mining Capital in Mexico," Latin American Perspectives 32, no 4. (July 2005): 65-86.

2 Oscar F, Contreras Montellano, ed. Cananea: tradición y modernidad en una mina histórica (México, D.F.: Colegio de Sonora, 1998).

3 Juan Luis Sariego, Luis Reygadas, Miguel Ángel Gómez, and Javier Farrera, El estado y la minería mexicana: política, trabajo y sociedad durante el siglo xx (México, D.F.: Fondo de Cultura Económica, 1988).

4 Juan Luis Sariego, Enclaves y minerales en el norte de México: historia social de los mineros de Cananea y Nueva Rosita, 1900-1970 (México, D.F.: Ediciones de la Casa Chata, 1988).

${ }^{5}$ Theodore B. Borek, "Evaluating a Developing Institution: Mexicanization of Mining," Arizona Law Review 13, no. 3 (1971), 685; David S. Browning, "Historic Basis of Mining Law," InterAmerican Law Review 7, no. 1 (January - July 1965): 3-4; Francisco Arellano Rendón, El subsuelo mexicano: patrimonio nacional (México: [s.n.], 1970), 107; Sariego, El estado, 368; María Becerra González, Derecho minero de méxico y vocabulario con definición de conceptos jurídicos-mineros (México, D.F.: Editorial Limusa-Wiley, 1963), 69; Robert B. Wallace Hall, La dinámica del sector minero en México, 1877-1970 (México: El Colegio de México, 1972), 126.
} 
of Mexicanization was a "radical measure." ${ }^{6}$ Sariego and others, however, have emphasized its moderate and pragmatic character. The latter contend that Mexicanization was a nationalist policy intended to assert greater control of the industry without alienating foreign investors and governments. Together, these works focus mainly on the relationships between the state, the private sector, and foreign investors in parastate enterprises. ${ }^{7}$

Mexicanization introduced the Mexican state into the mining industry and extended its role in the governance of Mexico. According to Sariego, Mexicanization ended the "imperial economic arrangement" known as the enclave. Since the beginning of its mining operations in 1899, Cananea had been owned by American companies and was "characterized by a close and tight relationship between the mining company and labor, with the state almost completely absent." 8 After Mexicanization, the Mexican state took on a greater role in municipal and administrative functions and advanced public projects such as housing, education, infrastructure, which had formerly been the domain of the mining company. As a consequence, the state's increased role in the governance of Cananea diminished the influence of the local mining union which, for decades, had served as the "natural representative" of the workers,

\footnotetext{
${ }^{6}$ Mendoza and Delgado Wise, "Mexicanization," 69.

7 Sariego, Enclaves, 291; Sariego, El estado, 362; Oscar F. Contreras Montellano, La minería en Sonora: modernización industrial y fuerza de trabajo (México, D.F.: Área de Estudios sobre Historia y Sociedad-El Colegio de Sonora, 1986), 15, 17.

${ }^{8}$ Sariego, Enclaves, 287; Sariego, El estado, 16, 248.
} 
responsible for protecting and advancing their interests against the unilateral influence of the Cananea Consolidated Copper Company. ${ }^{9}$

While the Mexican state increased its role in the mining industry, the Mexicanization policy also introduced an entirely new group to the industry domestic private interests. Mexicanization transformed the monopoly character of the mining industry formerly dominated by foreign interests and permitted the entry of Mexican investors. ${ }^{10}$ Delgado Wise and Mendoza have argued that Mexicanization constituted a "political strategy for the formation and consolidation of large mining capital."11 This policy successfully channeled public resources into the industry, permitting expansion and modernization projects, which were then transferred to private ownership in the late 1980s. They point out that this strategy did not create a new group of the Mexican bourgeoisie but permitted the growth and consolidation of an existing group associated with industrial and financial capital. ${ }^{12}$

Mexicanization also transformed the nature of foreign participation in the mining industry. In contrast to policies of direct nationalization, Mexicanization

\footnotetext{
${ }^{9}$ Sariego, El estado, 16.

${ }^{10}$ Oscar F. Contreras and Miguel Angel Ramirez, "Cananea: el largo camino de la modernización," in Cananea: tradición y modernidad en una mina histórica, eds. Oscar F. Contreras, Alejandro Covarrubias, Miguel Angel Ramírez, and Juan Luis Sariego Rodríguez (Hermosillo: Colegio de Sonora, 1998), 58; Contreras Montellanos, Mineria en Sonora, 16; Sariego, El estado, 12, 299, 310, 363-364; Browning, "Historical Basis of Mining Law," 25; Sariego, Enclaves, 299, 310; Delgado Wise and Mendoza, "Mexicanization," 66.

11 Delgado Wise and Mendoza, 65-66.

12 Delgado Wise and Mendoza, 72-73; Sariego, Enclaves, 293, 297; Sariego, El estado, 12.
} 
preserved foreign participation and even created new forms of dependence on foreign capital. ${ }^{13}$ The predominance of a single industrial corporation directly involved in production yielded to the indirect involvement of multiple transnational financial institutions. In this way, foreign interests became even more integrated into the workings of parastate enterprises such as the Compañía Minera de Cananea while obscuring their participation. ${ }^{14}$ According to Juan Luis Sariego and Raúl Santana Paucar, "[t]his new strategy permits transnational companies to control in a more effective manner the production and commercialization of minerals without eliminating. . . the participation of social capital of Mexicanized companies." ${ }^{15}$ The theme of Mexicanization appears throughout the previous works as a transformation of social relationships among state and domestic and foreign investors, but no real change in regarding dynamics of power.

With respect to labor, the scholarly treatment of Cananea's copper mine workers provides a valuable cultural perspective. The authors of Cananea: tradición y modernidad en una mina histórica have studied the challenges Mexicanization, and later, privatization, represented for Cananea's labor movement. In these analyses, Section 65 , the local branch of the national mining union, served as an expression of union culture. This union emphasized work as a source of both individual self-realization and social identity since it defined

\footnotetext{
${ }^{13}$ Sariego, Enclaves, 299, 313-316.

${ }^{14}$ Sariego, Enclaves, 299, 287-288, 304-305, 313-316.

15 Juan Luis Sariego and Raúl Santana Paucar, "Transición tecnológica y resistencia obrera en la minería mexicana," Cuadernos Políticos 31 (January - March 1982): 23.
} 
one's place in the local community and the Mexican nation. The studies have shown how Mexicanization transformed the traditional working lives of copper miners through technological innovation and structural reorganization. Efforts to privatize the company in the late 1980 s, to be discussed in the final chapter of this dissertation, represent a continuation of this process. Juan Manuel Silva Rodríguez argues that privatization constituted an existential threat to the revolutionary worker. Others have argued that privatization was an effort to dismantle a labor tradition that had transformed workers from a source of state legitimacy into a source of opposition to the state. ${ }^{16}$

These works demonstrate that the achievement of national sovereignty in the Mexicanization of the Compañía Minera de Cananea was problematic, to say the least. On the one hand, the transformation of the company into a parastate enterprise entailed an actual change in the company's ownership, transitioning from exclusive foreign proprietorship to majority Mexican control. On the other hand, the continued participation of foreign investors and the emergence of new

\footnotetext{
${ }^{16}$ Oscar F. Contreras, Alejandro Covarrubias, Miguel Angel Ramírez, and Juan Luis Sariego Rodríguez, "Introducción general: lecciones de una tradición sindical," in Cananea: tradición y modernidad en una mina histórica, eds. Oscar F. Contreras, Alejandro Covarrubias, Miguel Angel Ramírez, and Juan Luis Sariego Rodríguez (Hermosillo: Colegio de Sonora, 1998), 22-24, 31; Miguel Angel Ramírez and Alejandro Covarrubia, "Cultura sindical y flexibilidad laboral," in Cananea: tradición y modernidad en una mina histórica, eds. Oscar F. Contreras, Alejandro Covarrubias, Miguel Angel Ramírez, and Juan Luis Sariego Rodríguez (Hermosillo: Colegio de Sonora, 1998), 167; Contreras Montellanos, Mineria en Sonora, 36, 38; Oscar F. Contreras and Miguel Angel Ramírez, "Mercado de trabajo y relaciones laborales," in Cananea: tradición y modernidad en una mina histórica, eds. Oscar F. Contreras, Alejandro Covarrubias, Miguel Angel Ramírez, and Juan Luis Sariego Rodríguez (Hermosillo: Colegio de Sonora, 1998), 164; Miguel Ángel Ramírez Sánchez, Trabajo y relaciones laborales en una transición prolongada el caso de Mexicana de Cananea, antes Compañia Minera de Cananea (Hermosillo: M. Á. Ramírez Sánchez, 1996), 15; Juan Manuel Silva Rodriguez, "Mineros y minerales en crisis: la lucha continúa. miradas al sujeto histórico en las huelgas de Cananea, Sonora, 1906-2007," (Ph.D. dissertation, Centro de Investigaciones y Estudios Superiores en Antropología Social, 2011), 16,
} 
forms of dependence, and the changes experienced by workers, indicate discrepancies in the actual achievement of national sovereignty. These works suggest that parastate enterprises such as the Compañia Minera de Cananea projected a façade of nationalist control while obscuring a more complex reality. The primary objective of this dissertation then, is to study how the narrative and perception of nationalist control and the complex reality behind them were negotiated through official and popular discourses about national sovereignty.

\section{Key Terms, Theory, Approach}

In its examination of the Mexicanization of the Compañía Minera de Cananea, this dissertation adopts an interdisciplinary approach to study the relationship between politics, economics, and culture. In the process, it encounters a number of historiographical sub-themes namely state formation, political economy, labor, nationalism, class relations, and myth. These multiple strands of analysis converge in the concept of national sovereignty.

The achievement of national sovereignty is a key process in state formation. National sovereignty refers to the authority which resides within a nation defined by the geographical and political boundaries of a state. This authority implies both a negative meaning - freedom from external domination and interference - and a positive one - the freedom of a country to determine its own goals. ${ }^{17}$ In the nineteenth century, the pursuit of national sovereignty in

\footnotetext{
${ }^{17}$ Hent Kalmo and Quentin Skinner, "Introduction," in Sovereignty in Fragments: The Past, Present and Future of a Contested Concept, eds. Hent Kalmo and Quentin Skinner (Cambridge: Cambridge University Press, 2010), 2-3; Martti Koskenniemi, "Conclusion: Vocabularies of
} 
Mexico meant the pursuit of national independence from Spanish rule. In the twentieth century, the desire for national sovereignty implied, in particular, greater control of natural resources and their use for internal economic development. According to Oscar Oslak, state formation involves imposing a mode of dominance through politics and a capitalistic mode of production. ${ }^{18}$ Efforts to achieve national sovereignty entailed both - the consolidation of state power and the accumulation of capital.

In part, I use national sovereignty to distinguish it from the related concept of nationalism. Nationalism refers broadly to an ideology or worldview that organizes perceptions and meanings around the exaltation of the idea of nation. ${ }^{19}$ Within the context of Latin American history, Alan Knight has identified five types of nationalism: "political nationalism, cultural nationalism, economic nationalism, xenophobia, and nation-building."20 Although these forms of nationalism often overlap, economic nationalism provides the greatest conceptual utility in the current study. According to Winthrop Wright, economic nationalism emerged as a rejection of foreign companies operating in Latin

\footnotetext{
Sovereignty - Powers of a Paradox," in Sovereignty in Fragments: The Past, Present and Future of a Contested Concept, eds. Hent Kalmo and Quentin Skinner (Cambridge: Cambridge University Press, 2010), 239.

18 Oscar Oszlak, "The Historical Formation of the State in Latin America: Some Theoretical and Methodological Guidelines for Its Study," Latin American Research Review 16, no. 2. (1981): 6-7

19 Don H. Doyle, "Introduction: Americanizing the Conversation on Nationalism," in Nationalism in the New World, eds. Don H. Doyle and Marco Antonio Pamplona (Athens: University of Georgia Press, 2006), 27-28.

${ }^{20}$ Alan Knight, "Peasants into Patriots: Thoughts on the Making of the Mexican Nation," Mexican Studies/Estudios Mexicanos 10, no. 1 (Winter 1994): 138.
} 
America by countries seeking economic development and political independence. ${ }^{21}$ Conceptually, economic nationalism provides the ideological basis for pursuing concrete economic objectives in the name of national sovereignty.

The form of nationalism that took hold in Mexico during the twentieth century was known as revolutionary nationalism. Initially, nationalism became a strategy used during the Mexican Revolution to mobilize armies and build a mass following among the various belligerent factions. ${ }^{22}$ Afterwards, it became the foundational ideology of the new state - a means to foster political legitimacy, economic growth, and social cohesion. ${ }^{23}$ Siginificantly, the ideology of revolutionary nationalism provided, among others, the underpinnings of a political economy that incorporated socially progressive measures and the strong intervention of the state. Their consecration in the 1917 Constitution arranged the factors of production through the protection of labor and natural resources solidly "within the framework of modern industrial capitalism." ${ }^{4}$ Carlos Salas identifies revolutionary nationalism as "a social structure of accumulation: an articulated, historically specific set of institutions that organizes the process of

\footnotetext{
${ }^{21}$ Winthrop R. Wright, British-owned Railways in Argentina: Their Effect on Economic Nationalism, 1854-1948 (Austin, University of Texas Press, 1974), 7.

${ }^{22}$ Frederick C. Turner, The Dynamic of Mexican Nationalism, (Chapel Hill: University of North Carolina Press, 1968), 311.

${ }^{23}$ Roger Bartra, Blood, Ink, and Culture: Miseries and Splendors of the Post-Mexican Condition, (Durham: Duke University Press, 2002), 2; Turner, Dynamic, 6, 163-166, 308; Alan Knight, "The Myth of the Mexican Revolution," Past and Present, no. 209 (Nov. 2010): 229.

${ }^{24}$ Doyle, "Introduction," 27-28, fn. 29.
} 
capital accumulation in different ways, in different locations and historical periods." 25 Within this social structure, the state plays a predominant role in the accumulation of capital and is legitimized by the pursuit of social well-being. Adam Morton argues that in the Mexican Revolution, "state intervention and mass mobilization were conjoined to ensure processes of primitive accumulation and the creation of modern capitalism." 26

Critical to solidifying these processes has been the control of labor by the Mexican state. Numerous scholars have pointed to the role of President Lázaro Cárdenas (1934-1940) who integrated labor into the Mexican state by reorganizing the political structure along corporatist lines in the Partido Revolucionario Mexicano, the predecessor of the Partido Revolucionario Institucional. By incorporating labor into the ruling party, this reorganization eliminated the vestiges of "a politically and organizationally independent labor movement" 27 and transformed it into "a union bureaucracy, representing the State within the labor movement." ${ }^{28}$ Government unions engaged in strikes and rewrote collective contracts with the approval of the state, which served to

\footnotetext{
${ }^{25}$ Carlos Salas, "Social Structures of Accumulation and the Condition of the Working Class in Mexico," in Contemporary Capitalism and Its Crises: Social Structure of Accumulation Theory for the 21st Century, ed. Terrence McDonough, Michal Reich, and David M. Kotz (Cambridge, Cambridge University Press, 2010), 286.

${ }^{26}$ Adam D. Morton, Revolution and State in Modern Mexico: The Political Economy of Uneven Development (Lanham, MD: Rowman and Littlefield Publishers, 2011), 24-25.

${ }^{27}$ Dan La Botz, The Crisis of Mexican Labor (New York: Praeger, 1992), xiv.

28 Juan Felipe Leal, "The Mexican State: 1915-1973, A Historical Interpretation," Latin American Perspectives 2, no. 2, (Summer, 1975), 56.
} 
appease the labor movement without upsetting industrial relations, and institutionalizing a degree of control that permitted continuous economic growth from the 1940 s to the late 1960 s known as the Mexican Miracle. ${ }^{29}$

Processes of state-formation also require a cultural element. And so, added to the institutional mechanisms mentioned above, the ideology of revolutionary nationalism functioned as the symbolic means of labor's control. Roger Bartra has described nationalism, generally, as "a body of political theory that expresses the hegemonic vocation of the ruling class in the form of a multiclass alliance." ${ }^{30}$ The popular character of revolutionary nationalism, however, effectively concealed its elite designs. Frederick Turner suggests that revolutionary nationalism imposes "one group's particular interests as the interests of the nation." ${ }^{11}$ The problem then becomes one of identifying whose interests are included and whose are excluded from being defined as national interests. According to Thomas O'Brien, the Mexican Revolution expanded the scope of nationalism, formerly the exclusive domain of elites, to include peasants and workers. ${ }^{32}$ Irene O'Malley notes, though, that nationalism served as a progressive force but gradually became a repressive one: "It increasingly

\footnotetext{
${ }^{29}$ La Botz, 1, 6; Raúl Trejo Delarbe, and Aníbal Yanez, "The Mexican Labor Movement: 19171975." Latin American Perspectives 3, no. 1, Imperialism and the Working Class in Latin America (Winter, 1976): 133.

${ }^{30}$ Roger Bartra, Blood, Ink, and Culture: Miseries and Splendors of the Post-Mexican Condition (Durham: Duke University Press, 2002), 13.

31 Turner, Dynamic, 5.

32 Thomas O'Brien, The Revolutionary Mission: American Enterprise in Latin America, 1900-1945 (Cambridge: Cambridge University Press, 1999), 5; Turner, Dynamic, 56.
} 
became a force to dull political criticism and to detain the advance of the laboring classes by disguising middle-class interests as national interests." 33 Even the most progressive of constitutional measures, Articles 27 and 123, have been shown by Alan Knight to be a means to serve "elite economic nationalism." 34 So, despite its radical and social character, the Mexican Revolution gave rise to a new elite and reestablished class relations under the banner of revolution. ${ }^{35}$

These analyses present a fundamental interrogation. How do the popular elements of revolutionary nationalism harmonize with its elite facets? How is legitimacy sustained when the ideals of an ideology diverge from its political and economic realities? The pragmatic resolution of this dilemma resides in the historical uses of myth. In Brazilian Empire: Myths and Histories, Emilia Viotti da Costa argues that sometimes social myths conceal a "real rupture with the past" following a historical event. ${ }^{36}$ In her work, though, historical continuity is more enduring than historical change. In her analysis of Brazilian history, the myth of racial democracy disguised the endurance of the patronage system and institutionalized racism. Disguising these continuities was critical to the maintenance of elite hegemonic control: while providing opportunities for the

\footnotetext{
${ }^{33}$ Irene V. O'Malley, The Myth of the Revolution: Hero Cults and the Institutionalization of the Mexican State, 1920-1940 (New York: Greenwood Press, 1986), 123, fn 20.

${ }^{34}$ Alan Knight, "Peasants into Patriots," 151.

${ }^{35}$ Morton, Revolution and State, 18; James M. Cypher, State and Capital in Mexico: Development Policy Since 1940 (Boulder, Colo.: Westview Press, 1990), 19.

${ }^{36}$ Emília Viotti da Costa, The Brazilian Empire: Myths and Histories (Chicago: University of Chicago, 1985), 235.
} 
individual advancement of black Brazilians, the myth of racial democracy inhibited collective empowerment and group identity. ${ }^{37}$

The most prevalent myths in modern times are those associated with the nation according to Eric Hobsbawm. He uses the term "invented traditions" to refer to the nation and "its associated phenomena: nationalism, the nation-state, national symbols, histories and the rest." 38 These traditions needed to be invented because there was no intrinsic relationship of a group of people to the nation-state they resided in, and so national myths became critical to establishing an organic connection between the two. In the nineteenth century, national myths were particularly useful in breaking down the identification of workers with labor and socialist movements, cultivating, instead, their attachments to a nation whose interests could be defined by powerful elites. ${ }^{39}$

In Latin America and Mexico, labor became associated with the nation as a result of struggles against foreign exploitation in the late nineteenth and early twentieth centuries. According to Norman Girvan, conflicts between foreign investors and host countries "often become identified in the eyes of the government with the issue of national sovereignty, and [this is] why policies of nationalization of foreign industries have become so widespread in the Third

\footnotetext{
${ }^{37}$ Costa, Brazilian Empire, 235, 240.

${ }^{38}$ E. J. Hobsbawm, "Introduction: Inventing Traditions," in The Invention of Tradition, ed. Eric Hobsbawm \& Terence Ranger (Cambridge: Cambridge University Press, 1983), 13.

${ }^{39}$ E.J. Hobsbawm, Nations and Nationalism Since 1780: Programme, Myth, Reality (Cambridge: Cambridge University Press, 1992), 83; Hobsbawm, "Introduction," 7.
} 
World." ${ }^{" 40}$ Charles Bergquist has argued that the most radical workers in Latin America were those employed by foreign companies in the primary sector, such as mining, and, as a result, labor struggles became associated with nationalist struggles and viceversa. ${ }^{41}$ Julie Erfani indicates that elite support for nationalist causes came to be construed as support for labor's causes. She argues that the Mexican Revolution gave rise to a myth related to national sovereignty, in which "[t]he "popular sovereignty" of the Mexican people supposedly guaranteed that the new state would and could use its presumed powers to protect the socioeconomic well-being of all Mexican citizens."42

Because of the centrality of myths to the historical process under examinationthis study engages with the theoretical approaches offered by cultural history. Typically, cultural history often brings to mind three different spheres: "general human development (intellectual, spiritual or aesthetic), particular ways of life (of a people, or period), and the works and practices of art and intellect (music, literature, painting, theatre, film and so forth)." ${ }^{43}$ In The Other Rebellion: Popular Violence, Ideology, and the Mexican Struggle for

\footnotetext{
${ }^{40}$ Norman Girvan, "Economic Nationalism," Daedalus 104, no. 4, The Oil Crisis: In Perspective (Fall, 1975): 152.

${ }^{41}$ Charles Bergquist, Labor in Latin America: Comparative Essays on Chile, Argentina, Venezuela, and Colombia (Stanford: Stanford University Press, 1986), 11.

42 Julie A. Erfani, The Paradox of the Mexican State: Rereading Sovereignty from Independence to NAFTA (Boulder, Colo.: Lynne Riener, 1995), 3.

${ }^{43}$ Ben Marsden and Peter Gabriel McCaffrey, "Histories of Cultural History," in The Cultural History Reader, eds. Peter Gabriel McCaffery and Ben Marsden (London: Routledge, 2014), xxviii.
} 
Independence, 1810-1821, Eric Van Young critiques the traditional approaches

of cultural history, which present culture as a specialized sphere of human

activity. Arguing for a more expansive approach, he defines culture as the

codes and symbols by which groups of people impute meanings to the world of humans, things, and forces around them, and by which they convey that information to each other; by which they understand, represent, reinforce, or contest relations of power and domination; and above all through which they define their own identities by the stories they tell about themselves. ${ }^{44}$

From this perspective, culture resides within all spheres of human activity. He adds,

If people really live suspended in webs of meaning, then culture must be in many places where we cannot see it, or where it does not occur to us to look, or where it might appear as background to the central social action, as well as at those social loci and in those material objects to which convention directs our gaze. ${ }^{45}$

The current study, then, focuses less on the representations of symbolic meaning often prioritized in cultural history and rather looks at the meanings embedded in the concept of national sovereignty.

I analyze national sovereignty as a cultural concept in order to examine the fundamental, often unspoken, assumptions by which Mexican workers perceived and understood the world around them, and which guided their actions, behavior, and thought, particularly in their engagement with nature and work. Workers, however, often did not return home to write about such

\footnotetext{
${ }^{44}$ Eric Van Young, The Other Rebellion: Popular Violence, Ideology, and the Mexican Struggle for Independence, 1810-1821 (Stanford: Stanford University Press, 2001), 19.

${ }^{45}$ Eric Van Young, The Other Rebellion, 20.
} 
engagements. After a long day of work, mineworkers most likely spent their time relaxing, doing household chores, raising children, drinking, or any number of other activities. Works of cultural history often presented symbolic meaning as residing within human narratives and artifacts such as novels, paintings, or music. Scholars in the field of economic sociology, however, have suggested that economic practice itself conveys symbolic meaning. ${ }^{46}$

Much of the work of economic sociology emanates from Karl Polanyi's The Great Transformation (1949). ${ }^{47}$ Polanyi argued that the success of Western industrial societies depended on the transformation of nature, work, and money into natural resources, wage labor, and capital through a process of commodification. This transformation permitted their exchange and purchase in the marketplace, allowing the aspiring entrepreneur to produce goods, services, and profits. Because they were not originally produced to be sold or exchanged, he called these creations fictional commodities. In the process, nature, labor, and money are reduced to abstractions and subordinated to the market. ${ }^{48}$ Similarly, he criticized, in its search for immutable laws, economics reduced the complexity of human societies to economic models and subordinated them to the

\footnotetext{
${ }^{46}$ Frank Cochoy, Martin Giraudeau, and Liz McFall, "Performativity, Economics and Politics," Journal of Cultural Economy 3, No. 2 (July 2010): 140.

${ }^{47}$ Christopher Holmes, "Introduction: A Post-Polanyian Political Economy for Our Times," Economy and Society 43, no. 4 (November 2014); Tony Bennett, Liz McFall, and Mike Pryke, "Editorial," Journal of Cultural Economy 1, no. 1 (March 2008).

${ }^{48}$ Karl Polanyi, The Great Transformation (Boston: Beacon Press, 1957), 44.
} 
market. In this way, the economic sphere ended up imposing itself as the main determinant of social life. ${ }^{49}$

Polanyi's work offers two valuable insights for understanding economic phenomena. First, he suggests that work and the appropriation of nature through work emerge as constants in human societies but come in a multitude of forms. Second, Polanyi argued that economies are not autonomous but interwoven with the politics, culture, and other factors within a given society." 50

Economic sociologists have shown that economic practices are conjoined with cultural practices in processes of commodification. Often isolated as an economic practice, commodification is a process that includes social, political, historical, and cultural elements. Commodification is a cultural process because it involves "changing ways of valuing, classifying, and representing earlier forms of wealth and work." ${ }^{51}$ This process takes the qualitative aspects of a good or service and reduces it "to a single standard of pecuniary value." ${ }^{2}$ As market practices have normalized over time, lost is the understanding that such practices did not arise naturally or spontaneously but required active effort and

\footnotetext{
49 Polanyi, 60.

${ }^{50}$ Polanyi, 48, 76.

51 Jeffrey Sklansky, "The Elusive Sovereign: New Intellectual and Social Histories of Capitalism," Modern Intellectual History 9, no. 1 (April 2012): 242.

52 Sklansky, "The Elusive Sovereign," 234.
} 
intervention through "social habits, cultural logics, and the conditions of systembuilding." 53

Polanyi's insights and those of economic sociology are useful when thinking about national sovereignty as a discourse that normalizes economic practices and behaviors. In this respect, national sovereignty emerges as one of the cultural codes by which humans impart meaning to the world around them. As a discourse, national sovereignty provides insight into the "ways of thinking and behaving which are formed within a particular context." ${ }^{54}$ Discourses are particularly important for understanding historical change in how they "constrain and enable the possibility for innovation." 55 Some studies, such as those pursued by Theodor Adorno and the Frankfurt School, have investigated the intersection of culture and economics but have positioned culture as an externalized product of industrial society. The current study is more interested in the meaning of economic policies and practices in themselves. While commodification expresses meanings in relation to markets, discourses related to Mexican national sovereignty problematize these constructions. I present national sovereignty as a discourse that emerges as a way of thinking about

\footnotetext{
${ }^{53}$ Michael Zakim and Gary J. Kornblith, "Introduction," in Capitalism Takes Command: The Social Transformation of Nineteenth-Century America, eds. Michael Zakim and Gary J. Kornblith Chicago: University of Chicago Press, 2012), 2.

${ }^{54}$ Sara Mills, Discourse (London: Routledge, 2004), 15.

${ }^{55}$ Mills, 13.
} 
economic practices, distinct from processes of commodification but constrained by them at the same time.

My study of national sovereignty as a discourse engages a number of fundamental questions: What is the social character of natural resources? Who owns, controls, and determines the uses of natural resources? What are the social purposes of work? Who owns, controls, and determines the products of work? How is exploitation legitimized and how is society organized?

What else does it mean for this dissertation to examine national sovereignty as a discursive ordering of nature and work in Mexican society? I study how the perception of nationalist control over natural resources (and the complex reality 'matching' it) was negotiated through official and popular discourses of national sovereignty. To understand the nuances of these competing and complementary discourses, I examine the entanglements of meaning associated with national sovereignty and how they evolved throughout the twentieth century. In the next five chapters, this dissertation examines the connotative meanings of national sovereignty as they surfaced through historical, social, and political processes; how these were engaged in the Mexicanization of the Compañía Minera de Cananea; and, how they opened up some opportunities for social action while foreclosing others.

I analyze national sovereignty along four categories of inquiry. First, I investigate the nature of Mexicanization and ask to what degree did this policy help achieve national sovereignty in Mexico? Second, I interrogate national sovereignty for insight into fundamental cultural assumptions related to nature, 
work, and the political organization of the world. Third, I consider how these perceptions are shaped by class, looking particularly at the bifurcation of national sovereignty into popular and elite forms. Finally, I examine national sovereignty as a paradigm that is, at once, opposed and complementary to the hegemony of global capitalism and the organization of the world around market culture.

\section{Sources}

This dissertation employed a wide variety of sources to examine the discourse of national sovereignty. The first chapter analyzes seventeen official histories and memoirs, published between 1936 and 1989, related to the strike of 1906 in Cananea. I demonstrate how these texts emphasize and connect those portions of Cananea's history related to myth into a coherent narrative about the labor movement, the nation, and the Mexican Revolution. Beginning in the second chapter, laws and congressional debates concerning mining, oil, and bureaucracies supply critical information. They reveal how discourses of elite and popular national sovereignty emerged in relation to the Mexicanization law in 1961, and the law's implementation in the particular case of the Compañía Minera de Cananea, in 1971.

A variety of periodical sources appear throughout this dissertation. Editorials regional and national newspapers provide diverse perspectives on national sovereignty. The source that offers the most direct perspective of copper mine workers themselves is the weekly newspaper published by the local section of the national mining union: 1906 Semanario: órgano oficial de la Sec. 
65 del S.I.T.M.M.S.R.M. Cananea, Sonora. ${ }^{56}$ This periodical began its publication in 1943 when the business elites of Mexico began reasserting their power after the nationalization of the oil industry in 1938. The Mexican government had also begun imposing tighter restrictions on labor with the beginning of Mexican involvement in the Second World War. ${ }^{57}$ This publication has an been essential source for transmitting union culture and historical memory, highlighting company violations and labor abuses, promoting worker and community solidarity, organizing and sustaining strikes, and connecting local concerns to national issues.

Archival sources related to the business history of the Compañía Minera de Cananea were also valuable. These included documents produced by Nacional Financiera, a development bank which owned the Compañía Minera de Cananea. Most abundant from 1985 to 1990, this collection includes company reports, internal correspondence, and loan agreements. I used these and other archival collections to examine the material and empirical implications of national sovereignty.

A number of important sources were inaccessible and unavailable. The presidential papers of Luis Echeverría (1970-1976) and the Archivos del Estado de Sonora in Hermosillo remained inaccessible due to disorganization and a lack

\footnotetext{
${ }^{56}$ Out of a thirty-year span from December 1960 to December 1990, seven and a half years were missing from the available collection at the Colegio de Sonora. Four years, from 1963 to 1967, were missing entirely. Three and a half years of issues were missing from mid-1985 to 1990.

${ }^{57}$ Sariego, Enclaves, 261-262.
} 
of funding. Two of the most promising collections, The Archivo Laboral de la Compañía Minera de Cananea and the Archivo Legal de la Compañía Minera de Cananea were destroyed in a fire during a labor strike in 2007.

\section{Organization}

This dissertation is divided into five, largely chronological chapters. Chapter one examines the outbreak of a strike in Cananea in 1906 and Cananea's role in the Mexican Revolution from 1910 to 1920 . It argues that the myth of Cananea created an association between the working class, the Mexican nation, and the Mexican Revolution. This fusion provided legitimacy to the elite project of economic nationalism, the rise of the Mexican state, and later to the Mexicanization of the Compañía Minera de Cananea in 1971.

The second chapter focuses on the passage of the Mexicanization of Mining Law in 1961. It argues that the nationalization of the oil industry in 1938 became the dominant expression of national sovereignty, associated with ownership and management by the Mexican state and the exclusion of foreign participation. The conservative reaction that followed forced a change in nationalist policy and a change in the meaning of national sovereignty, leading to the policy of Mexicanization. As a result, state intervention became oriented toward serving private interests.

While Mexicanization emerged as a policy that appealed to conservatives, the ownership change to the Compañía Minera de Cananea in 1971 retained popular appeal, which is the subject of chapter three. Although the process of 
Mexicanization differed from nationalization, it was presented as an equivalent form of national sovereignty. Natural resources were to be controlled by Mexican nationals for the sake of ensuring economic and social development. While preserving the participation of foreign investors, Mexicanization also implied the continued subservience of the working class to the Mexican state.

The fourth chapter examines the fate of Compañía Minera de Cananea from 1971 to 1989 and demonstrates the weaknesses of Mexicanization in terms of the self-proclaimed national sovereignty attached to it. While reducing foreign control of mineral resources and introducing the private sector into the industry, forms of dependence were preserved. The process also failed to improve social and economic outcomes for Cananea's mining workers. As Mexicanization failed to improve the well-being of workers, they increasingly questioned their ties to the Mexican nation.

Chapter five demonstrates how the experiment of Mexicanization came to an end on August 20, 1989 when the company was declared bankrupt and its facilities occupied by the Mexican army. These violent efforts toward the company's ultimate privatization were considered across the country as signaling the end of the Mexican Revolution. These events were accompanied by the efforts of the Carlos Salinas administration to renegotiate the meanings of national sovereignty, and deconstruct the broad framework of labor, the nation, and the Mexican Revolution established in the myth of Cananea. 


\section{CHAPTER I}

\section{The Myths of Cananea: Labor, the Nation, and the Mexican Revolution}

The legitimacy for the Mexicanization of the Compañía Minera de Cananea in 1971 resided in a series of events that occurred at the beginning of the twentieth century. In June 1906, mine workers in Cananea went on strike against an American company, the Cananea Consolidated Copper Company. The event turned violent and led to the intervention of American soldiers at the invitation of the Mexican government. Soon after, what had begun as an isolated labor action in a remote part of the country erupted into a national controversy as a violation of Mexican sovereignty. As a result, the labor strike became interpreted as a struggle against American imperialism and became the basis for a myth that promoted the identification of the working class with the Mexican nation. Later, this myth also became associated with the outbreak of the Mexican Revolution, and Cananea became known as "the cradle of the revolution."

With respect to myths, the precision of historical fact emerges as a secondary concern. More important is how myths function as hegemonic discourses about, for instance, alleged historical change as opposed to actual continuity. According to Emilia Viotti da Costa, historical continuity is often more enduring than historical change, so myths emerge to conceal the lack of "real rupture with the past." ${ }^{1}$ During the Mexican Revolution from 1910 to 1920, the

\footnotetext{
${ }^{1}$ Emília Viotti da Costa, The Brazilian Empire: Myths and Histories (Chicago: University of Chicago, 1985), 235, 240.
} 
continuity ultimately concealed was the enduring domination of Mexican elites both before and after the conflict. Popular struggles transformed the conflict from a political revolution into a social one that promised to bring fundamental change to Mexican society. As the conflict wore on, the middle-class nationalist faction known as the Constitutionalists managed to take control and impose their own vision on Mexican society. According to Thomas Benjamin, the myth of the Mexican Revolution "reinforce[d] elite and thus national political unity, to establish a solid historical foundation upon which to unify all revolutionary factions past and present."2 Alan Knight argued that in addition to its symbols and iconography, the myth of the Revolution included policies such as "land and labour reform, indigenismo, education, and economic nationalism" which formed the "project of the revolution." ${ }^{3}$ Such policies enhanced elite control over the process as a whole, which became a nationalist crusade. This chapter shows how elite rule endured after the revolution and became channeled into the new project of economic nationalism, legitimized by the myth of Cananea.

This chapter argues that the events of Cananea gave rise to a myth composed of three elements. The first posits Cananea as the birthplace of the modern labor movement in Mexico and ascribes the workers in 1906 with political and revolutionary motivations. The second element of myth attributes an antiimperialist and nationalist sentiment to the labor struggles in 1906. The final

\footnotetext{
2 Thomas Benjamin, La Revolución: Mexico's Great Revolution as Memory, Myth, and History (Austin: University of Texas Press, 2000), 21-22, 33.

${ }^{3}$ Alan Knight, "Myth of the Mexican Revolution," Past and Present, no. 209 (Nov. 2010): 228.
} 
element of myth identifies Cananea as "the cradle of the Mexican Revolution," connecting the strike in 1906 to the conflict that began in 1910. In the myth of Cananea, labor and the nation come together through the Mexican Revolution.

The myth of Cananea emerged to mobilize the support of labor and generate legitimacy for the post-revolutionary state. According to Eric Hobsbawm, national traditions were invented to, among others, establish a (manufactured) connection between the working class and the nation. ${ }^{4}$ In the nineteenth and early twentieth century, the working class in Mexico overall possessed no discernible relation to the Mexican nation. Also, unlike the grassroots agrarian movement, the working class possessed no organic relation to the beginnings of the Mexican Revolution. Where previously labor consisted of incoherent groups of labor affiliated to small local political groups, the myth of Cananea brought labor squarely within the domain of the nation. This maneuver advanced the successes of labor but also quite critically, became a means to control labor. In the process, the myth ascribed popular legitimacy to that part of the revolutionary project, most closely aligned with the aspirations of the elite economic nationalism.

This chapter studies the entanglement of labor, the nation, and the Mexican Revolution in official histories published between 1936 and 1990 related to the 1906 strike in Cananea. These provide essential context for

\footnotetext{
${ }^{4}$ E. J. Hobsbawm, "Introduction: Inventing Traditions," in The Invention of Tradition, ed. Eric Hobsbawm \& Terence Ranger (Cambridge: Cambridge University Press, 1983), 7, 13; E.J. Hobsbawm, Nations and Nationalism Since 1780: Programme, Myth, Reality (Cambridge: Cambridge University Press, 1992), 83.
} 
understanding the Mexicanization of the Compañía Minera de Cananea in 1971. In addition to providing background, this chapter analyzes the events of the 1906 strike, and analyzes the three elements of myth that became associated with it: the beginning of the modern labor movement in Mexico, anti-imperialist and nationalist struggles, and the cradle of the Mexican Revolution.

\section{Background}

In contrast to the long history of mining in Mexico, the emergence of Cananea as an important mining center was a late development. Jesuit missionaries had begun mining silver as early as 1760 , but these efforts were terminated when King Charles III ordered their expulsion from Spanish America in $1767 .{ }^{5}$ The development of mining in Sonora was further delayed by the wars of independence in the early nineteenth century and only began to revive in the second half of the nineteenth century after the appointment of General Ignacio Pesquiera as the state's governor. A hero of the Reforma and the wars against French intervention, Pesquiera pacified indigenous peoples in the region and soon after, he claimed titles to seven mines in Cananea, built a smelter, and began producing copper until his death in $1886 .^{6}$

\footnotetext{
5 José Luis Trueba Lara, Cananea, 1906 (Hermosillo: Gobierno del Estado de Sonora, 1989), 2, 60; Manuel J. Aguirre, Cananea: Las garras del Imperialismo en las entrañas de México (México, D.F.: Libro Mex Editores, 1958), 20; Eugenia Meyer, Cynthia Rading, Martha Rocha, and Guadalupe Villa, La Lucha obrera en Cananea, 1906 (México, D.F.: Secretaría del Trabajo y Previsión Social, 1980), 24; Manuel Arrellano Z., Huelga de Cananea, 1906 (Partido Revolucionario Institucional: Talleres de la editorial libros de México, 1976) 3, 5, 64.

${ }^{6}$ Trueba Lara, Cananea, 63.
} 
Critically, Pesquiera's intervention was accompanied by technological and political change. Advancements in electricity and the growth of modern industry in Europe and the United States created a new demand for copper, which previously had been limited to the production of tools, currency, architecture, and cultural artifacts. These global developments transformed Cananea from an isolated settlement on the Mexican frontier into an important resource for the modern world. ${ }^{7}$

Just as important as technological change were the political developments in the final quarter of the nineteenth century. Since 1820, Mexico's experience as an independent nation had been marked by political instability, economic stagnation, and territorial loss. The election of General Porfirio Díaz in 1876 initiated a period known as the Pax Porfiriana marked by stability and pacification. Upon this foundation, President Díaz initiated policies that encouraged economic and industrial development by attracting foreign investment in the form of "generous tax breaks, concessions, and favorable mining laws."

\footnotetext{
7 Juan Manuel Romero Gil, La minería en el noroeste de México: utopía y realidad, 1850-1910 (México: Universidad de Sonora, Plaza y Valdés Editores, 2001), 109, 211, 212; Ramón Eduardo Ruiz, The People of Sonora and Yankee Capitalists (Tuscon: University of Arizona Press, 1988), 38.

${ }^{8}$ Michael J. Gonzales, "United States Copper Companies, the State, and Labour Conflict in Mexico, 1900-1910," Journal of Latin American Studies 26, no. 3 (October 1994): 653; Romero Gil, 109, 165; Ruiz, People of Sonora, 2; Daniel González Cortés, Cananea (México: Compañia Minera de Cananea, 1985), 1, 11-12; Aurora Maycotte Perez, "La huelga de Cananea," in La huelga de cananea: tres monografias. Contribución de los alumnos del primer curso de civismo, Grupo "G," de la escuela secundaria num. 6, a la celebración del 1st de Mayo (México, D.F.: Talleres Gráficos de la Nación, 1936), 25-26; Manuel González Ramírez, La huelga de Cananea (México, D.F.: Fondo de Cultura Económica. Fuentas Para la Historia de la Revolución Mexicana, III, 1956), viii.
} 
the construction of railroads and the subsequent development of export agriculture, livestock, petroleum, and mining. In Cananea: Las garras del Imperialismo en las entrañas de México, Manuel J. Aguirre emphasizes that this process introduced a subtler form of imperialism. ${ }^{9}$ Mexico suffered no more territorial losses but persisted as a coveted prize to foreign investors who became the new agents of imperialism. The rise of Cananea as an important mining center in the early twentieth century represented the extension of American imperial ambitions. ${ }^{10}$

The encroachment of American imperialism into northern Mexico is attributed, in particular, to the efforts of William C. Greene. ${ }^{11}$ Early works by American historians presented Greene as a romantic personification of the American West, "the most swashbuckling figure in the history of the Mexican mining industry."12 American newspapers praised "his resourcefulness, his foresight, his great dream of opening the Mexican wilds to industry and agriculture, his energy, his success."13

\footnotetext{
${ }^{9}$ Manuel J. Aguirre, Cananea: Las garras del imperialismo en las entrañas de México (México, D.F.: Libro Mex Editores, 1958).

${ }^{10}$ Compañía Minera de Cananea, Cananea y la Revolución Mexicana (Cananea: Compañía Minera de Cananea: 1987), 9; Ruiz, People of Sonora, 32; Emily Rosenberg, Financial Missionaries: The Politics and Culture of Dollar Diplomacy, 1900-1930 (Cambridge, Mass: Harvard University Press, 1999).

${ }^{11}$ Meyer et al., Lucha obrera, 39; Ismael Valencia Ortega, Cananea (Hermosillo: INAH-SEP, Centro Regional del Noroeste, 1984), 26.

12 Marvin Bernstein, "Colonel William C. Green and the Cananea Copper Bubble," Bulletin of the Business Historical Society (December 1952): 179; Charles L. Sonnichsen, Colonel Greene and the Copper Skyrocket: The Spectacular Rise and Fall of William Cornell Greene Copper King, Cattle Baron and Promoter (Tuscon: University of Arizona, 1974), 260.

${ }^{13}$ Sonnichsen, 4.
} 
Mexican historians offered a different perspective. Juan Manuel Romero Gil described Greene as "a human archetype of the history of capitalism and of the West of the United States," a man who mixed the conduct of business with personal vice and lawlessness. ${ }^{14}$ Manuel J. Aguirre condemned the selfdescribed colonel as a criminal and a murderer who "author[ed]...the massacre of Mexicans." ${ }^{\text {15 }}$ Armando Rubio Cubillas described Greene and his American employees as "corrupt Americans, a conglomerate of human garbage, composed of criminals pursued by the laws of their country, whose apprehension offers a monetary reward, of fugitives from their prisons, of defeated Ku Klux Klan, conceited and accustomed to subjugate black slaves."16 Outcast in their own country, they took their beliefs and practices to neighboring Mexico where the lingering memory of American aggression in the mid-nineteenth century exacerbated the impression of Greene as an imperialist.

After he arrived in Cananea in the late nineteenth century, William Greene established an array of companies to mine copper and exploit the natural resources of the area. As the foundation of this enterprise, he formed an operating company based in Mexico, the Cananea Consolidated Copper Company in September 1899, and then created a holding company based in

\footnotetext{
${ }^{14}$ Romero Gil, 220; Trueba Lara, Cananea, 67.

${ }^{15}$ Aguirre, 7; Armando E. Rubio Cubillas, Huelga de obreros en Cananea. (Hermosillo, Sonora, México: Imparcolor, 1990), 22-23, 139.

${ }^{16}$ Rubio Cubillas, 139.
} 
West Virgina, the Greene Consolidated Copper Company, in February 1900. In addition, he founded a network of subsidiaries related to lumber, railroads, communications, and cattle to facilitate his mining operations. ${ }^{17}$

Greene needed people to work the mines and, toward this effort, he became responsible for creating modern day Cananea. After acquiring titles to the mines, he purchased nearly 3 million acres of land from a group of American businessmen. After Cananea became a municipality on October 13, 1901, Greene acquired 90 out of 150 "manzanas," more than half of total municipal property. ${ }^{18}$ To support a working population he then established public services, industries, markets, and infrastructure. Churches, schools, and hospitals materialized as social outgrowths of imperial investments. In this way, according to Eugenia Meyer, "the dominion of foreign capital in Cananea penetrated the daily life of the community."19 Population and economic growth quickly transformed Cananea from an isolated outpost into the most important city in the state. Before long, it became the district seat. These changes encouraged the acquiescence of Porfirian officials in Mexico City to Greene's activities in far off Sonora. The payment of salaries and bonuses to municipal officials extended the company's political control and allowed it to "influence the appointment of the

\footnotetext{
17 Trueba Lara, Cananea, 67, 91; Valencia Ortega, Cananea, 23; Aguirre, 159; Daniel González Cortés, Cananea (México: Compañia Minera de Cananea, 1985), 1, 16; Romero Gil, 227; Sonnichsen, 59; Bernstein, "William C. Green," 179-198; Meyer et al., Lucha obrera, 32-37, 42.

${ }^{18}$ Trueba Lara, Cananea, 88; Sonnichsen, 70-71.

${ }^{19}$ Meyer et al., Lucha obrera, 30.
} 
President and the other members of the city council, assuring the submission of the authorities to the interests of the company." 20

\section{6 and the heroic Mexican workers}

By 1906, Greene's entrepreneurship had transformed Cananea from an isolated frontier outpost into a booming mining town. Almost inevitably, this generated problems among the workforce, including a major strike at the beginning of the 20th century. The strike that occurred in June 1906 has been interpreted in two ways. In the secondary literature, Alan Knight and Michael Gonzales have argued that the events were largely spontaneous and motivated by the pragmatic, economistic concerns of the workers. ${ }^{21}$ The official histories of Cananea assert that the workers' actions were planned and motivated by political and revolutionary objectives. These sources impart a pro-worker and antiimperialist character to the events in Cananea.

The official histories present Cananea as the birthplace of the modern labor movement in Mexico. According to Jorge Sayeg Helú, the strike of 1906 signaled the end of workers' complacency and resignation, and the beginning of a "sporadic, naive, and natural" class consciousness among Mexican workers. ${ }^{22}$

\footnotetext{
${ }^{20}$ Meyer et al., Lucha obrera, 29.

${ }^{21}$ Alan Knight, The Mexican Revolution (Lincoln: University of Nebraska Press, 1986), 1:145; Michael J. Gonzales, “United States Copper Companies, 1900-1910,” 651.

22 Jorge Sayeg Helú, Las huelgas de Cananea y Río Blanco (México, D.F.: Patronato de Instituto Nacional de Estudios Históricos de la Revolución Mexicana, 1980), 50, 65; León Díaz Cárdenas, Cananea, primer brote del sindicalismo en México (México, D.F.: Centro de Estudios Históricos del Movimiento Obrero Mexicano, 1976), 7-8; González Ramírez, xxxvii-xxxviii; Arrellano Z., 5.
} 
Esteban Baca Calderón, one of the strike's primary leaders, noted that the struggle in Cananea contained "the germ of all future struggles of Mexican workers." 23

In these texts an important role is ascribed to the Partido Liberal Mexicano. The PLM formed at the beginning the twentieth century in response to the political, economic, and social problems caused by the Porfirian elite in Mexico City. ${ }^{24}$ The same policies which contributed to the Pax Porfiriana, political stability and economic growth, also contributed to economic disparities and social unrest. In their journal Regeneración, first published in 1900, Ricardo and Enrique Flores Magón castigated Porfirian officials for exploiting Mexicans and suppressing "all labor organization...[and] all political rights" for the enhancement of foreigners' wealth, oligarchical government, and bureaucratic patronage. ${ }^{25}$ Of the two brothers, Ricardo emerges as the most prominent historical figure in commemorations of Cananea. He has been described as "one

\footnotetext{
${ }^{23}$ Estéban Baca Calderón, Juicio sobre la guerra del Yaqui y génesis de la huelga de Cananea (México, D.F.: Centro de Estudios Históricos del Movimiento Obrero Mexicano, 1975, First Edition, 1956), 9; Soyla Gallegos Torres, "Antecedentes de la Revolución de 1910," in La huelga de cananea: tres monografias. Contribución de los alumnos del primer curso de civismo, Grupo "G," de la escuela secundaria num. 6, a la celebración del 1st de Mayo (México, D.F.: Talleres Gráficos de la Nación, 1936), 17.

${ }^{24}$ Díaz Cárdenas, 23, 30, 70; Valencia Ortega, 57; Baca Calderón, Juicio, 52; Enriqueta de Parodi, Mineros: la huelga de Cananea (México: 1960), 56; Jesús Morales Tapia, Los campos mineros de Cananea (México: Compañía Minera de Cananea, 1985), 64-67.

${ }^{25}$ Rodolfo del Castillo Moreno, "Resumen," in La huelga de cananea: tres monografias. Contribución de los alumnos del primer curso de civismo, Grupo "G," de la escuela secundaria num. 6, a la celebración del 1st de Mayo (México, D.F.: Talleres Gráficos de la Nación, 1936), 21-22; Begoña Hernández y Lazo Huelga de Cananea (México, D.F.: Instituto Nacional de Estudios Históricos de la Revolución Mexicana, 1985), 10.
} 
of the most forgotten men in the national politics of our Republic" 26 and as the real ideologue of the Mexican Revolution and the 1917 Constitution. ${ }^{27}$

Among the readership of Regeneración were the future leaders of the Cananea strike. Esteban Baca Calderón and Manuel M. Diéguez founded the Unión Liberal Humanidad on January 16, 1906. Several months later, Lázaro Gutiérrez de Lara formed the Club Liberal de Cananea. The early concerns of these clandestine groups were focused on long-term organization and preparation: "to propagate the ideas of liberty and. . to build up a solid base of support before taking dramatic direct action." ${ }^{28}$ Although formed separately, the leaders eventually sought to join the two clubs into the Unión Minera de Cananea to increase their chances of success against the company. While these efforts were being made, interactions between Mexican workers and American workers who belonged to the Western Federation of Miners prepared the ideological ground among ordinary workers by providing "the bases for the construction of a class consciousness, organization, and strategy."29 Apart from the activities of the liberal clubs, these influences shaped and helped workers articulate their demands. On May 5, 1906, a month before the strike, Baca Calderón gave a speech that called for preparation. But for the remainder of the month, "in small

\footnotetext{
${ }^{26}$ September 18, 1973.

27 Diario de los Debates de los Diputados: November 21, 1972; November 29, 1984. October 10, 1973; November 19, 1985; December 13, 1988; December 20, 1993.

${ }^{28}$ González Ramírez, 3-4.

29 Trueba Lara, Cananea, 77-78.
} 
groups and private meetings, heated commentaries. . [awoke] the impatience of all Mexicans who suffered humiliations by racial discrimination." ${ }^{30}$ The leaders had begun preparing the ground, but the workers moved on their own. ${ }^{31}$

The strike began during the early morning hours on June 1, 1906. The previous night, the management of the Oversight mine announced a change in the payment of wages, primarily affecting the lowest paid workers who received three pesos a day. The company wanted to increase productivity and output, but these changes also increased competition, intensity, and the insecurity of work. Hours after the announcement, four hundred workers walked out of the Oversight mine in a spontaneous protest. Only after the strike began were the eventual leaders woken and asked to lead the movement. Baca Calderón later wrote that he and the other leaders felt the timing was inopportune but nonetheless agreed to lead the strike. Early planning and influences provided the foundation, but it was the immediacy of outrage that prompted workers to take action. By noon, all mining operations had ceased, and the number of demonstrators exceeded two thousand workers. ${ }^{32}$

\footnotetext{
${ }^{30}$ Baca Calderón, Juicio, 82; Baca Calderón, Cananea, 21; Sayeg Helú, 56.

${ }^{31}$ González Ramírez, vii, xxiii; Baca Calderón, Juicio, 32, 57, 81; Aguirre, 55, 81; Valencia Ortega, 57; Díaz Cárdenas, 13, 23, 25-26, 31-32; Esteban Baca Calderón, Cananea (México: SEP-Conasupo, 1981), 5-6, 12, 21 (where is first instance; Francisco Medina Hoyos, Cananea: cuna de la Revolución Mexicana, en el cincuentenario de la primera gran huelga proletaria de México (México, D.F., 1956), 42, 111; Rubio Cubillas, 196; Gallegos Torres, "Antecedentes," 16; Meyer et al., Lucha obrera, 67; Sayeg Helú, 12; Hernández y Lazo, 10; Arrellano Z., 15.

32 Baca Calderón, Juicio, 56, 82; Gallegos Torres, "Antecedentes," 16; Castillo Moreno, "Resumen," 23; Díaz Cárdenas, 27, 32; Meyer et al., Lucha Obrera, 69, 70, 72-73; Baca Calderón, Cananea, 12; Arrellano Z., 21.
} 
The workers' committee presented two main grievances to the company's management. The first centered on the ethnic division of labor, "an internal regimen of work based on the discrimination between North American workers on one side and Mexican workers on the other." ${ }^{33}$ American workers monopolized positions such as foremen, engineers, and accountants, which were considered the best jobs in terms of responsibility, skill, and salary. According to José Luis Trueba Lara, the exclusion of Mexicans from such positions proceeded from an "analogous division between material and intellectual labor," in which Mexican workers were "considered. . . a simple beast of burden" who deserved an occupation and wage "equal to his race."34

The second grievance focused on the dual wage scale. In this arrangement, Mexican laborers were paid less than their American counterparts holding the same job. In general, American workers received good wages and experienced a comfortable standard of living; Mexican workers and their families, in contrast, remained in poverty. According to Romero Gil, this imparted workers "a painful and denigrating impression of inferiority, of pariahs and of strangers in their own country." ${ }^{35}$ Greene exacerbated these grievances when he tried to pass off three silver pesos as equivalent to three gold dollars. When confronted about these disparities, Greene claimed that the necessities of business

\footnotetext{
${ }^{33}$ Sayeg Helú, 49; Trueba Lara, Cananea, 84.

34 Trueba Lara, Cananea, 85; González Ramírez, xxx; Medina Hoyos, 88.

${ }^{35}$ Romero Gil, 339; Arrellano Z., 7, 9; Baca Calderón, Juicio, 25-26; Baca Calderón, Cananea, 5; Ruiz, People of Sonora, 87.
} 
determined wages. His opponents, according to the official histories of Cananea, countered that American capitalist practices were inseparable from racial discrimination. ${ }^{36}$

Workers subsequently demanded the firing of an abusive manager, a minimum wage of five pesos for eight hours of work, a minimum employment of Mexican nationals, and the opportunity for advancement. These demands for economic restitution were interwoven with demands related to racial justice, dignity, respect, fairness, and equality. ${ }^{37}$

Greene responded by arguing that the workers' grievances and demands were baseless, exaggerated, and the work of agitators. According to León Díaz Cárdenas, Greene's uncompromising posture and threats emanated from a "capitalist logic" meant to deter further demands or actions by workers. ${ }^{38}$ At the same time, Greene felt that he had bestowed a service to Mexico by providing jobs, wages, public services, and other amenities to its people. He presented himself as an imperial benefactor who paid wages so high that he was siphoning off workers from other enterprises. His magnanimity left room for no further increases. To do otherwise, he claimed, would lead to closures. Yet, while

\footnotetext{
${ }^{36}$ Maycotte Perez, "La huelga de Cananea," 30; Díaz Cárdenas, 23; Arrellano Z., 5, 7; Meyer et al., Lucha obrera, 68-69. Gallegos Torres, "Antecedentes," 15; Rubio Cubillas; González Ramírez, xxxi.

${ }^{37}$ Baca Calderón, Juicio, 61-62; Hernández y Lazo, 15; Aguirre, 113; Meyer et al., Lucha obrera, 74-76 ; Aguirre, 73; Díaz Cárdenas, 21-22, 33-34; Arrellano Z., 7-9, 11; Rubio Cubillas, 140; Parodi, 89, 96-96; Medina Hoyos, 58-59, 113, 117; Sonnichsen, 178, 182; González Ramírez, 6; Sayeg Helú, 49, 57-58; Castillo Moreno, "Resumen," 23-24.

${ }^{38}$ Díaz Cárdenas, 37, 43.
} 
mineworkers may have received some of the highest wages in Mexico, the high cost of living and the high cost of goods at the company store barely permitted survival. ${ }^{39}$ Greene's rejection angered the demonstrators who resumed their march, "silent and ordered, [a] tactic adopted to avoid all provocation that would permit the authorities, servants of capitalism, to argue with their guns." ${ }^{\text {"0 }}$

In contrast to the Mexican protestors who demonstrated peacefully, Greene prepared for violence. The night before, he had traveled to Arizona where he amassed a small arsenal, returned to Cananea the next morning, and distributed the arms to his "trusted employees." ${ }^{41}$ Before the first meeting between company managers and workers had even taken place, Greene had already raised the possibility of violence, sending Sonoran governor Rafael Izábal warnings that the peaceful crowds were becoming an imminent threat. His warnings soon became reality, not because of the actions of Mexican workers, but rather those of Greene's American employees. When the protestors arrived at the lumberyard during their march, they were met by George and William Metcalf who trained industrial firehoses on them. Surprised and unarmed, the workers retaliated by stoning the two brothers - one of whom shot into the rushing crowd, killing and wounding several Mexicans before the survivors killed

\footnotetext{
${ }^{39}$ Arrellano Z., 7,9; Díaz Cárdenas, 21-22, 37-39, 43, 45-46; Baca Calderón, Cananea, 3; González Cortés, 1, 16; Ruiz, People of Sonora, 76, 102; Castillo Moreno, "Resumen," 23; González Ramírez, xxiii; Valencia Ortega, 27; Meyer et al., Lucha obrera, 27-28.

${ }^{40}$ Díaz Cárdenas, 48; Baca Calderón, Cananea, 25.

${ }^{41}$ Cárdenas Garcia, La huelga de Cananea, 130; Meyer et al., Lucha obrera, 72.
} 
the remaining brother. They set fire to the lumberyard and fled. During their escape, they encountered Greene and his armed employees who fired on the demonstrators from rooftops, automobiles, and horseback, killing and wounding men, women, and children. ${ }^{42}$

Later that night, the night of June 1, 1906, Greene sent more telegrams, over a dozen, to Governor Izábal with the purpose of inciting alarm. He also sent exaggerated reports of violence to the American press warning of an impending race war and the annihilation of all "American men, women, and children." 43 Under pressure to quell the protests, Governor Izábal made an ill-fated decision by requesting help from the United States military. Vice President Ramón Corral tried to intervene, prohibiting the request, but his telegram arrived too late. On the morning of June 2, 1906, Colonel Thomas Rynning and almost three hundred Arizona Rangers crossed the border. When they reached Cananea, the soldiers took up positions guarding "the company store, the bank, the general office, the foundry, the new concentrator, and the wood deposit." ${ }^{44}$ Emilio Kosterlisky, commander of the Rurales, arrived in the afternoon and found everything under control. He dispersed the remaining groups of Mexican workers, who had resumed their peaceful protest, declared martial law, imposed a curfew, and persuaded Greene to send the Rangers back to the United States. The

\footnotetext{
42 Díaz Cárdenas, 31, 50; Medina Hoyos, 66, 68, 98; Aguirre, 74, 142; Arrellano Z., 11; Maycotte Perez, "La huelga de Cananea," 31; Meyer et al., Lucha obrera, 77-78.

${ }^{43}$ Arrellano Z., 13; Baca Calderón, Cananea, 27-30.

${ }^{44}$ Baca Calderón, Juicio, 104; Baca Calderón, Cananea, 32; Díaz Cárdenas, 62.
} 
American soldiers spent only twelve hours in Cananea, patrolling the streets and intimidating passersby, but otherwise perpetrated no violence. ${ }^{45}$

The next day, General Luis E. Torres and the Federal Army arrived and issued an ultimatum: Return to work or be conscripted to fight the Yaqui Indians in southern Sonora. The strike's leaders were arrested along with nearly one hundred protesters. The remainder returned to work while others migrated to the United States. By June 5th the strike was over. ${ }^{46}$

These events have given rise to Cananea's association as the birthplace of the progressive labor movement in Mexico. Yet, the workers' primary motivations for the strike were not driven by the desire for political or revolutionary change but were related to immediate bread-and-butter concerns with the conditions of work and the pragmatic needs of everyday life ${ }^{47}$ Alan Knight contends that the influence of the PLM "appears to be doubtful, and at best inconclusive." 48 Workers questioned management and operations, but never the capitalist system, foreign investment, or the prevailing political system. They sought to defend their material interests and gain dignity in their work, but

\footnotetext{
${ }^{45}$ Meyer et al., Lucha obrera, 80-82; Medina Hoyos, 85, 91; González Ramírez, xxvi; Baca Calderón, Cananea, 32; Aguirre, 74; Maycotte Perez, "La huelga de Cananea," 31-32; Ramón Eduardo Ruiz, Labor and the Ambivalent Revolutionaries: Mexico, 1911-1923 (Baltimore: Johns Hopkins University Press, 1976), 111-112.

${ }^{46}$ Hernández y Lazo, 18; Meyer et al., Lucha obrera, 82-83; González Ramírez, xxvi; Medina Hoyos, 110. Cárdenas Garcia, La huelga de Cananea, 144.

${ }^{47}$ Gonzales, “U.S. Copper Companies, 1900-1910,” 651; Knight, Mexican Revolution, 1:145.

${ }^{48}$ Rodney D. Anderson, Outcasts in Their Own Land: Mexican Industrial Workers, 1906-1911 (DeKalb: Northern Illinois University Press, 1976), 315.
} 
had no interest in an "armed revolutionary commitment."49 Violence by industrial workers, such as occurred in Cananea, did not indicate a larger revolt but an isolated event, a last resort "to correct specific abuses and settle specific scores." 50 The myths of Cananea, however, emphasized the political and radical character of labor thus manufacturing a rather artificial link between labor and the Mexican Revolution. A similar and related link was crafted concerning nationalism.

The second element of myth related to Cananea involves the joining of labor's struggles with nationalist ones. The central thesis in E. J. Hobsbawm's Nations and Nationalism Since 1780: Programme, Myth, Reality, contends that a population residing within the borders of a political state bears no intrinsic relation to this political entity, but had to be cultivated through the development of nationalism. Before a narrative posing this association surfaced, the allegiance of workers rested primarily with labor unions and socialist parties. ${ }^{51}$ The events in Cananea provided the foundation for an "invented tradition" which connected labor to the Mexican nation while imparting an anti-imperialist character to labor struggles. ${ }^{52}$

\footnotetext{
${ }^{49}$ Anderson, ix; 313-316, 320-323.

${ }^{50}$ Knight, Mexican Revolution, 1:144-145; Cárdenas Garcia, La huelga de Cananea, 118, 130.

51 E.J. Hobsbawm, Nations and Nationalism Since 1780: Programme, Myth, Reality (Cambridge: Cambridge University Press, 1992).

${ }^{52}$ E. J. Hobsbawm, "Introduction: Inventing Traditions," in The Invention of Tradition, ed. Eric Hobsbawm \& Terence Ranger (Cambridge: Cambridge University Press, 1983).
} 
By June $5^{\text {th }}$ the strike had ended, but its effects reverberated and intensified as the event became a national scandal. On June 2, the Los Angeles Times reported that American officials inside the State Department expressed their bewilderment that "a governor of a foreign state. . . ask[ed] for help to suffocate an interior movement." ${ }^{53}$ Porfirian officials had wanted "to establish order at whatever price," ${ }^{54}$ but instead of reestablishing order, Governor Izábal exacerbated problems by "wounding. . . the nationalist sentiment of our compatriots." ${ }^{25}$ The violence against the Mexican workers came at the hands of Greene's employees, but it was the entry of the Arizona Rangers into Mexico that generated outrage. According to Baca Calderón, the trespass of American soldiers achieved what no political leader could accomplish - the unification of liberals and conservatives in Mexico. Political leaders and newspapers vilified the governor and demanded Izábal's punishment for violating national sovereignty. General Torres castigated him for allowing foreign troops to enter national territory without congressional authorization. Vice President Corral tried to protect Izábal by altering the governor's reports, but the backlash eventually forced the governor before the Grand Jury of the Chamber of Deputies. The official was acquitted, though, through the intervention of Corral and President Díaz. ${ }^{56}$

\footnotetext{
53 González Ramírez, xxviii. LA Times, June 2, 1906.

${ }^{54}$ González Ramírez, xxviii, xxvi; Gallegos Torres, “Antecedentes,” 16.

55 Gonzalez Ramírez, xxvi.
} 
Although labor problems initiated the strike in Cananea, it was the violation of sovereignty that turned the event into a national issue. Without the entry of American soldiers, Cananea may easily have been forgotten. Several historians noted the silence regarding the actual violence against workers. According to Begoña Hernández y Lazo, "in no moment was the stance of the government authorities and the company against the workers on strike questioned." ${ }^{77}$ León Díaz Cárdenas stated, "[n]othing was said about the workers massacre... [nor the] bloody repressions from the authorities and the company. . . in the capital, they spoke of international codes, and of national sovereignty." ${ }^{58}$ Manuel Aguirre wrote that the elites of the country, conservative and liberal alike, had come together but "[i]t certainly was not [due to] compassion [or] noble sentiment" for the plight of the worker. ${ }^{59}$ These authors reveal that the perceived violation of national sovereignty by American troops emerged primarily as an elite concern while those of labor remained peripheral.

\footnotetext{
${ }^{56}$ Baca Calderón, Juicio, 96, 103; Baca Calderón, Cananea, 23, 25, 28, 31; James D. Cockcroft, Intellectual Precursors of the Mexican Revolution (Austin: University of Texas Press, 1968), 135136; John Hart, Revolutionary Mexico: The Coming and Process of the Mexican Revolution (Berkeley: University of California, 1987), 62, 68; Medina Hoyos, 96, 98, 116, 117; González Ramírez, xxvii, xxix, xxxv-xxxviii; Gonzales, “U.S. Copper Companies, 1900-1910," 673; Sayeg Helú, 65-66; Díaz Cárdenas, 76, 96, 116; Aguirre, 143; Hernández y Lazo, 18

${ }^{57}$ Hernández y Lazo, 18.

${ }^{58}$ Díaz Cárdenas, 68-69.

${ }^{59}$ Aguirre, 149.
} 


\section{Revolution}

So far, the elements of myth surrounding Cananea involve the alleged political and nationalist aspirations of workers during the events of 1906.

Cananea's ascription as the "cradle" of Mexican Revolution is a third component. Similar to the ones above, this has also been shown to be tenuous. Several problems followed after the strike, but they did not give rise to militancy nor radicalism among Cananea's workers. Financial difficulties in the second half of 1906 led to a takeover of Greene's companies and his removal from the board of directors in mid-February 1907. Later that year, an economic crisis in the United States led to the shutdown of operations and to a modernization project that kept mining operations closed until $1911 .{ }^{60}$ The size of the workforce and its wages were subsequently reduced, anti-unionization efforts strengthened, and a permanent army garrison built to suppress future disturbances. Overall, the period following the strike until the outbreak of the Mexican Revolution, from June 1906 to November 1910, was one of "quiescence rather than militancy." ${ }^{1}$

The concerns of workers in Cananea and workers in general remained peripheral at the beginning of the Mexican Revolution. In his book, La sucesión presidencial published two years before the revolution, Francisco I. Madero harangued Porfirian crimes in Cananea but only in reference to the violation of national sovereignty. Cananea became a tool for propaganda against the administration of Díaz rather than an expression of real concern for workers'

\footnotetext{
${ }^{60}$ Gonzales, "U.S. Copper Companies, 1900-1910," 674-677, 680; Bernstein, "William C. Greene," 195-196; Sonnichsen, 214-216, 219; Romero Gil, 241.

${ }^{61}$ Knight, Mexican Revolution, 2:149; Knight, Mexican Revolution, 1:130, 142, 149.
} 
rights. No mention was made of the strike itself nor the problems of workers. Madero's leadership also signified the eclipse of the social liberalism of the PLM, "the most radical current of the Mexican Revolution" and the working class's only identifiable advocate. ${ }^{62}$ The radicalization of the conflict was the work of the agrarian and campesino struggles led by Emiliano Zapata and Pancho Villa respectively. It was these leaders who were responsible for transforming Madero's political revolution into a social one. Their efforts were essential not only to the military outcomes of the conflict, but also to injecting agrarian and other social issues into the revolutionary project. ${ }^{63}$

Cananea's importance and main role throughout the conflict centered on its being a source of financing for the various revolutionary factions. After restructuring and installing new facilities, the Cananea Consolidated Copper Company reopened in 1911 and resumed production levels achieved before the strike. Maderista revolutionaries largely continued the policies instituted by the Díaz administration, particularly those favoring foreign investors with concessions and tax exemptions. Toward labor, their attitude was one of appeasement. But appeasement quickly transformed into repression after workers resumed their antagonistic stance and engaged in a series of strikes in November 1911,

\footnotetext{
${ }^{62}$ González Ramírez, xvii; Sayeg Helú, 14-15, 44; Meyer et al., Lucha obrera, 83; Díaz Cárdenas, 14-15.

${ }^{63}$ Francisco I. Madero, La sucesión presidencial en 1910, (Mexico: Libreria de educación de B. de la Prida, 1909). https://babel.hathitrust.org/cgi/pt?id=njp.32101007756958;view=1up;seq=9 (accessed October 20, 2017), 168-170; Knight, Mexican Revolution, 1:148; Adolfo Gilly, The Mexican Revolution, trans. Patrick Camiller (London: Verso Editions and NLB, 1983), 302; Valencia Ortega, 43.
} 
February 1912, and December 1912. Such actions, among others, revealed the limited nature of Madero's revolution. "On its labor record, the Madero regime proved more conservative than revolutionary. . The defense of traditional interests, juxtaposed with a fear of radical change, dictated a quixotic stance at odds with the aspirations of the industrial worker." ${ }^{64}$ With the antagonism between workers and the Maderistas growing, the American owners of the 4C's threatened to shut down the mines again. ${ }^{65}$

After Madero's assassination in 1913, the Constitutionalists emerged as a new revolutionary force and positioned themselves as mediators between the company and labor in the hopes of securing greater control of vital financial resources. To finance the revolution, they needed operational mines and a reliable labor force, which meant asserting authority over both Mexican workers and the American company. To assert greater control of the company, the Constitutionalists nullified the privileges and concessions acquired during the Porfiriato. The company's executives, already upset by the cancellation of contracts and double taxation by competing revolutionary factions, considered these revocations a direct attack. They wanted "a return to prerevolutionary business practices" but indicated their willingness to settle for "compensation for the lost revenues and higher taxes." ${ }^{\text {6 }}$ When it became apparent that the

\footnotetext{
${ }^{64}$ Ruiz, Labor and Ambivalent Revolutionaries, 26, 28.

65 Gonzales, "U.S. Copper Companies, 1910-1920," 506-508, 525-527; Ruiz, Labor and Ambivalent Revolutionaries, 28-29; Knight, Mexican Revolution 1: 425-426.

${ }^{66}$ Gonzales, “U.S. Copper Companies, 1910-1920," 522.
} 
Constitutionalists represented their best chances in Mexico, foreign investors followed along. Indeed, the Constitutionalists wanted the mines to remain in American hands but wanted to extract more taxes from them. When the Constitutionalists, led by Carrancista General Alvaro Obregón, secured Cananea on March 24, 1915, they secured both the recognition by the United States on October 1915 and a steady stream of revenue for the remainder of the revolution. ${ }^{67}$

While presented as the cradle of the revolution, Cananea and its workers played only a peripheral role at the beginning of the Mexican Revolution. The causal link from the 1906 strike to the outbreak of the revolution in 1910 remains weak. ${ }^{68}$ The myth ascribed to Cananea a more revolutionary pedigree than was warranted, since its workers really did not start the revolution.

\section{Revolutionary Nationalism}

So far, this chapter has examined three elements of myth associated with Cananea - its association with the modern labor movement, the nation, and the Mexican Revolution. The ideology of revolutionary nationalism linked these three components of myth, eventually consecrated in the 1917 Constitution.

The most significant participation of labor in the military aspect of the revolution consisted of the Red Battalions formed in 1915. Until this point, the

\footnotetext{
${ }^{67}$ Gonzales, "U.S. Copper Companies, 1910-1920," 516, 518, 523, 525, 527, 529; Knight, Mexican Revolution, 2:505, 507; Valencia Ortega, 48.

${ }^{68}$ Gonzales, “U.S. Copper Companies, 1900-1910,” 651; Knight, Mexican Revolution, 1:145.
} 
involvement of labor had been limited to "individual, not group or organizational decisions." 69 This changed when the Constitutionalists searched for military and political allies and found them among the urban industrial workers associated with the Casa del Obrero Mundial. In mid-February 1915, the two sides signed a pact in which "the Casa promised to recruit workers for his armies and to win over labor to the Constitutionalists" in return for legislative guarantees that favored labor. ${ }^{70}$ Excluding the more radical workers in the railroad and mining industries, the Red Battalions consisted of about five thousand urban workers from Mexico City and Veracruz sent to fight for the Constitutionalists against Villa and Zapata. The battalions comprised between nine to twelve percent of the total Constitutionalist forces and played only an auxiliary role in the fighting. ${ }^{71}$

The Constitutionalists also wanted to control the working class. The Constitutionalist leader, Venustiano Carranza, was "a landlord who distrusted all labor unions"72 and he "wanted no rivals, left-wingers or revolutionaries heading labor groups." ${ }^{73}$ His allies watched out for any attempts to create labor unions that sought any position independent from the Constitutionalists. For the most part, the Casa served as a faithful ally of the Constitutionalists, recruiting soldiers

\footnotetext{
${ }^{69}$ Ruiz, Labor and Ambivalent Revolutionaries, 49; Héctor Aguilar Camín, and Lorenzo Meyer, In the Shadow of the Mexican Revolution: Contemporary Mexican History, 1910-1989, trans. Luis Alberto Fierro (University of Texas Press, 1993), 59.

${ }^{70}$ Ruiz, Labor and Ambivalent Revolutionaries, 51.

${ }^{71}$ Ruiz, Labor and Ambivalent Revolutionaries, 47; Knight, Mexican Revolution, 2:320-321.

72 Ruiz, Labor and Ambivalent Revolutionaries, 48.

${ }^{73}$ Ruiz, Labor and Ambivalent Revolutionaries, 52.
} 
and propagating Carrancismo but in some areas such as Orizaba (Veracruz), its leaders worked to create "an independent proletarian base." ${ }^{74}$ In fall 1915, months after the pact had been signed, the Carrancistas began closing the Casa's offices, confiscating radical propaganda, and arresting its authors. The battalions were disbanded in early 1916 and strikers were increasingly met with repression. In July, Carranza renewed a law from the Reforma era, which decreed the death penalty for any act of sabotage related to property or production such as strikes or work stoppages. Unlike the agrarians who had Zapata, the campesinos who had Villa, and the middle-class who had the Constitutionalists, the dissolution of the Casa del Obrero Mundial entailed the loss of labor's singular representative in the Mexican Revolution. ${ }^{75}$

The long-term strategy of the Constitutionalists went beyond the suppression of labor organizations, however. The governments of Porfirio Díaz and Francisco Madero each had made initial moves toward a settlement with labor and each had succumbed to his prejudices and used violence against workers. Unlike the regimes before him, "Carranza and his administration had bowed to the inevitability of labor unions. . But, in the course of Carranza's revolution and that of his successor's, government won control of labor."76 This was achieved by adding workers' grievances to the agenda of revolutionary

\footnotetext{
${ }^{74}$ Knight, Mexican Revolution, 2:425.

${ }^{75}$ Ruiz, Labor and Ambivalent Revolutionaries, 47, 53-55, 68; Meyer et al., Lucha obrera, 63-64.

${ }^{76}$ Ruiz, Labor and Ambivalent Revolutionaries, 61.
} 
nationalism, addressing their short-term needs with long-term consequences. This maneuver provided an institutional connection to the revolutionary state, simultaneously securing labor's loyalty and subordination to the Mexican nation. In contrast to the supporters of Villa and Zapata, the Constitutionalists were the only belligerents who "thought of their struggles as a contention for national hegemony." ${ }^{77}$ Labor's alliance with the Constitutionalists reinforced the association of its struggles, especially those directed against foreign-owned companies, with nationalist struggles. ${ }^{78}$ However, Cananea's mineworkers were rather removed from the central stage.

The ultimate rapprochement between labor and the Constitutionalists resided in the guarantees provided by Article 123 of the 1917 Constitution. Article 123 established a maximum workday, weekly rest, minimum wage, profitsharing, guarantees to safe working conditions, and the responsibility of companies for workplace accidents, injuries, and sickness. These guarantees supported the claims later made by historians who emphasized the radical nature of the Mexican Revolution. Preceding the Russian Revolution, the 1917 Constitution emerged as the most progressive social document of its time, whose guarantees for workers no other constitution provided. Integrating workers' protections into the juridical and constitutional makeup of the Mexican nation strengthened labor's bond to the nation, which before the revolution had

\footnotetext{
${ }^{77}$ Aguilar Camín and Meyer, 57.

78 Gonzales, “U.S. Copper Companies, 1910-1920," 505, 525; Aguilar Camín and Meyer, 57-59.
} 
remained the sole domain of the elites. In the late $19^{\text {th }}$ and early $20^{\text {th }}$ centuries, "the Mexican working class was socially a very narrow group, without cohesion or consciousness of its interests."79 Its first ideological influences were from "Italian and Spanish anarcho-syndicalists, and. . . by the radical slogans of the Mexican Liberal Party and the Flores Magón brothers." ${ }^{80}$ In Cananea, before the 1906 strike, associations between Mexican workers and American workers were stronger than any patriotic or nationalist feeling toward Mexico but weakened after the promulgation of the 1917 Constitution.

Article 123 was not just a response to labor's demands, but an essential component in the political economy of revolutionary nationalism. Critically, economic nationalism was not an original revolutionary aspiration: "It did not represent the culmination of revolutionary aims, or of popular demands (for 'the people' adhered to no abstract economic nationalism and generally favored the presence of foreign business, which fostered jobs and trade)." ${ }^{11}$ Instead, it was the "response of a new elite to particular circumstances" and emerged for "strategic than for any long-term ideological reasons." ${ }^{2}$ This was the work of a small group of intellectuals and politicians who wanted "to establish an equilibrium between the bargaining power of labor and capital." 83 Article 123,

\footnotetext{
${ }^{79}$ Aguilar Camín and Meyer, 59.

${ }^{80}$ Aguilar Camín and Meyer, 59.

${ }^{81}$ Knight, Mexican Revolution, 2:506.

${ }^{82}$ Knight, Mexican Revolution, 2:506.

${ }^{83}$ Knight, Mexican Revolution, 2:67, 100, 505, 508; Ruiz, Labor and Ambivalent Revolutionaries, 68.
} 
together with article 27 , emerged as the two pillars of revolutionary economic nationalism, as a mode of equilibrium between landed and labor interests. As progressive as the 1917 Constitution may have been, "Even a total commitment to uphold Article $123 \mathrm{kept}$ intact the economic status quo. . . The implementation of labor's platform simply updated Mexican capitalism by introducing forms of capital-labor relations increasingly common in Western European countries." ${ }^{84}$ The myths of Cananea, emphasizing the role of labor, added popular legitimacy to the program of revolutionary economic nationalism, a program that emerged not from popular revolutionary demands but rather from the demands of a middle-class, formerly denied political power who now had elite aspirations. Still, the various myths continued and grew, becoming the raw material behind various commemorations.

\section{Commemorations}

The strike of Cananea has been incorporated into the narrative of Mexican history through official histories, songs, movies, and folklore. According to José Luis Trueba Lara, Cananea has become "a point of obligated reference" 85 and "the cornerstone of all literature that has been written about the working class and the Mexican Revolution." ${ }^{86}$ While commemorations of the 1906 strike

\footnotetext{
${ }^{84}$ Ruiz, Labor and Ambivalent Revolutionaries, 75.

85 José Luis Trueba Lara, Voces de la mina: seis textos sobre Cananea (Hermosillo, Sonora: Programa Cultural de las Fronteras, 1988), 5.

${ }^{86}$ José Luis Trueba Lara, Cananea, 1906 (Sonora: Gobierno del Estado de Sonora, 1989), 27.
} 
occurred in a variety of forms, the event lacked the official treatment of revolutionary heroes such as Pancho Villa, Emiliano Zapata, and Francisco Madero. ${ }^{87}$

Official commemorations sanctioned by the Partido Revolucionario Institucional began in 1956 on the fiftieth anniversary of the strike, continued regularly throughout the 1960 s and 1970 s, and declined in the $1980 s^{88}$ An attempt by the national mining union to create June $1^{\text {st }}$ into a national holiday was made in October 1957, but never came up for vote. ${ }^{89}$ More often, the strike of 1906 was commemorated indirectly. Lawmakers and government officials mentioned Cananea during remembrances of the Mexican Revolution, the Constitution of 1917 , the nationalization of the petroleum industry in 1938, and celebrations of May $1 .{ }^{90}$ The events of 1906 Cananea were also invoked in homage to historical figures including Francisco I. Madero, Pancho Villa,

\footnotetext{
${ }^{87}$ Irene V. O'Malley, The Myth of the Revolution: Hero Cults and the Institutionalization of the Mexican State, 1920-1940 (New York: Greenwood Press, 1986).

88 Diario de los Debates de la Cámara de los Diputados del Congreso de los Estados Unidos Mexicanos: May 31, 1956, May 31, 1960; May 28, 1964; May 27, 1965; Junio 10, 1965; May 25, 1967; May 23, 1968; June 12, 1969; May 25, 1971; May 29, 1972; May 23, 1973; May 16, 1975; May 26, 1976; May 25, 1977; May 24, 1978; May 30, 1980; May 28, 1982.

89 Diario de los Debates de la Cámara de los Diputados del Congreso de los Estados Unidos Mexicanos: October 22, 1957; October 29, 1957. Sindicato Nacional de Trabajadores Mineros, Metalúrgicos, Siderúrgicos y Similares de la República Mexicana.

90 Diario de los Debates de la Cámara de los Diputados del Congreso de los Estados Unidos Mexicanos: February 5, 1950; March 19, 1975; November 23, 1917; "Primero de Mayo, Símbolo de Lucha Social en Orbe: Las Gestas Obreras de México ha sido Paradigma de Nuestra Clase," El Nacional, April 30, 1984; "Desde 1912 se Festeja en México el Día del Trabajo: Una Celebración en Memoria de los Mártires de Chicago," El Nacional, May 2, 1987; "Se Refrendó la Alianza Estado-Trabajadores," El Nacional, May 2, 1988.
} 
Venustiano Carranza, , and Ricardo Flores Magón as well as common

politicians, teachers, and union leaders. ${ }^{91}$ Lawmakers also mentioned Cananea

and its associations with the Mexican Revolution to generate support for

proposed legislation. ${ }^{92}$

In Cananea, memorials took on a variety of forms. These included street

names, buildings, clubs, and baseball fields named after distinguished miners

and employees ${ }^{93}$ monuments such as the mausoleum "Martyrs of 1906", the

house of William C. Greene,${ }^{94}$ and the Cananea jail, declared a national

monument on July $14,1981 .{ }^{95}$ The union weekly, the 1906 Semanario: Organo

oficial de la Sección 65 del Sindicato Industrial Trabajadora Mineros

91 Diario de los Debates de la Cámara de los Diputados del Congreso de los Estados Unidos Mexicanos: Francisco I. Madero, October 30, 1973, November 15, 1984; Venustiano Carranza, May 23, 1973; Francisco Villa, June 6, 1974; Maestro Enrique Corona Morfín, May 19, 1975; Don Miguel Hidalgo Y Costilla, December 6, 1985; Ricardo Flores Magón y José María Pino Suárez, December 2, 1975; Aquiles Serdán, November 15, 1977; Carmen Serdán, November 12, 1985;

Adolfo López Mateos, September 28, 1976; Ricardo Flores Magón: October 10, 1973; November 19, 1985; December 13, 1988;; September 18, 1973; November 21, 1972; November 29, 1984;

Eduardo Neri, union leader: December 29, 1969; Demetrio Vallejo Martínez, union leader:

December 26, 1985.

92 Diario de los Debates de la Cámara de los Diputados del Congreso de los Estados Unidos Mexicanos: Reorganizaiton of ministries, October 24, 1932; Modifications to Expense Budgets, December 21, 1921; December 28, 1977; Reforms Social Security Law, January 25, 1949; Ley Orgánica de la Contaduría, November 8, 1978; Election reforms , August 29, 1967; Federal Labor Law, May 28, 1919, October 15, 1976, April 20, 1978, October 21, 1986; Reforms and amendments to Article 123 of 1917 Constitution December 23, 1959; February 8, 1972; Ley Reglamentaria del Artículo 27 Constitución en Materia Nuclear, November 10, 1978, November 16, 1978.

${ }^{93}$ Morales Tapia, Los campos mineros, 37, 46-49.

94 Visited during research trip to Cananea, May 2016.

95 Julio Sosa Ballesteros, Cananea: un pueblo que jamás morirá. Ciudad Centenaria - Álbum Fotográfico, 1901-2001, 15, 18, 21. 
Metalúrgicos y Siderúrgica Mexicano, has perpetuated the social memory of the strike since $1950 .{ }^{96}$

\section{Conclusion}

In the official histories, Cananea is presented as the birthplace of the modern worker's movement, and as a movement inspired by nationalist and revolutionary ideals. Together, the myth of Cananea fundamentally brought labor within the domain of the Mexican nation and the Mexican Revolution. This multifold myth, though, obscures the continuity of Mexican society that persisted after the Mexican Revolution. During the course of the Revolution, the radicalization of the conflict promised to bring not only political change but to restructure Mexican society as well in fundamental ways. Yet, as the Constitutionalists became predominant, they were increasingly able to impose their interests as though they were true national interests, and thus ultimately shaped the final outcome of the revolution. While helping to reshape Mexican society in significant ways, the ideology of revolutionary nationalism also helped reestablish class relations, permitting the dominance of a new elite legitimized by the social promises of the revolution. The popular base that gave legitimacy to the Constitutionalists, however, resided not among the agrarian and campesino forces that radicalized the revolution but within the ranks of the labor movement. Through the myth of Cananea, labor emerged as a popular base, revolutionary in

96 1906: Semanario, Órgano Oficial de la Sec. 65 del S.I.T.M.M.S.R.M.. Tomo VII, no. 652. (Cananea, Son.) June 1, 1956. Special issue: Cincuentenario de la Huelga de Cananea. 
its own right, rather than as a member of an alliance merely serving elite interests. Subsequently, this myth imparted a popular façade to that part of the revolutionary project most aligned with elite interests - economic nationalism. 


\section{CHAPTER II \\ The Mexicanization of Mining Law, 1961}

More than four decades after the revolution, and more than four centuries since the arrival of Spanish conquistadors, the Mexican government made its strongest efforts to assert sovereign control of its mineral resources. Before 1961, nationalist policies had been implemented in a number of industries, but it was the nationalization of the oil industry in 1938 which has stood out the most in the history of Mexico, and which Alan Knight called "the apotheosis of revolutionary nationalism."1 Where the myth of Cananea had tied together labor, the nation, and the Mexican Revolution, the 1938 event added another layer of cultural meaning. The dominant expression of national sovereignty became associated with nationalization as the direct ownership and management of an industry by the Mexican state, foreign participation being excluded thereafter. The conservative reaction that followed the nationalization, however, transformed how the Mexican state asserted control over its mineral resources more than two decades later.

When President Adolfo López Mateos signed the Mexicanization of Mining Law in 1961, it represented the clash of nationalist impulses and reactionary forces. Raúl Delgado Wise and Rubén del Pozo Mendoza considered the policy of Mexicanization a radical measure because, through state intervention, it successfully overturned the structure of mining property, formerly monopolized

\footnotetext{
1 "Alan Knight, "Introduction," in The Mexican Petroleum Industry in the Twentieth Century," ed. Jonathan C. Brown and Alan Knight (Austin: University of Texas, 1992), xv.
} 
by foreign ownership. ${ }^{2}$ The scholarly consensus, however, points toward the policy's moderation: Mexicanization steered a middle path between the aspiration to assert nationalist control over mineral resources and the need to accommodate private and foreign interests. It was a strategic effort, mindful of the difficulties faced after the oil nationalization in 1938, to produce change while minimizing negative effects; and, was a relatively successful venture. It was a less intense and less remarkable effort than nationalization but was strong enough to satisfy nationalistic demands without alienating a majority of the Mexican and foreign business community. ${ }^{3}$

The Mexicanization of mining has received considerably less attention from scholars than the nationalization of oil. ${ }^{4}$ One noticeable gap in the existing

\footnotetext{
${ }^{2}$ Raúl Delgado Wise and Rubén Del Pozo Mendoza, "Mexicanization, Privatization, and Large Mining Capital in Mexico," Latin American Perspectives 32, no 4. (July 2005): 69; Juan Luis Sariego, Luis Reygadas, Miguel Ángel Gómez, and Javier Farrera. El estado y la minería mexicana: política, trabajo y sociedad durante el siglo xx (México, D.F.: Fondo de Cultura Económica, 1988), 250, 362.

${ }^{3}$ David S. Browning, "Historic Basis of Mining Law," Inter-American Law Review 7, no. 1 (January-July 1965): 27; Theodore B. Borek, "Evaluating a Developing Institution: Mexicanization of Mining," Arizona Law Review 13, no. 3 (1971): 685, 689, 695; P. E. Sigmund, Multinationals in Latin America: The Politics of Nationalization (Madison: University of Wisconsin Press, 1980), 5355, 78; Taeko Hoshino, Industrialization and Private Enterprises in Mexico (Chiba: Institute of Developing Economies-Japan External Trade Organization, 2001), 92; Sariego, El estado, 362; Rafael Izquierdo, Política hacendaria del desarrollo establizador, 1958-1970 (Mexico City: Colegio de Mexico, 1995), 110, 113; Juan Luis Sariego, Enclaves y minerales en el norte de México. Historia social de los mineros de Cananea y Nueva Rosita, 1900-1970 (México, D.F.: Ediciones de la Casa Chata, 1988), 291.

${ }^{4}$ Lorenzo Meyer, Mexico and the United States in the Oil Controversy, 1917-1942 (Austin: University of Texas Press, 1977); George W. Grayson, The Politics of Mexican Oil (Pittsburgh: University of Pittsburgh Press, 1980); Jonathan C. Brown, Oil and Revolution in Mexico (Berkeley: University of California Press, 1993); Linda B. Hall, Oil, Banks, and Politics: The United States and Postrevolutionary Mexico, 1917-1924 (Austin: University of Texas Press, 1995); Myrna I. Santiago, The Ecology of Oil: Environment, Labor, and the Mexican Revolution, 19001938 (Cambridge: Cambridge University Press, 2006).
} 
literature involves the lack of clarity regarding Mexicanization as a nationalist process. While Mexican scholars on the topic provide a clear analysis of it, American contributions often present Mexicanization as equivalent to nationalization. ${ }^{5}$ Clear empirical information is critical to revealing the cultural shift that took place in the meanings of national sovereignty from nationalization to Mexicanization. Without precise information, the study of cultural meanings affirms Stephen Haber's critique of the new cultural history as "ontologically and epistemically subjective." ${ }^{\prime}$ Subsequently, this chapter offers a comparative analysis of the nationalization of Mexico's oil industry and the Mexicanization of its mining industry in order to provide a clear understanding of their differences. In this chapter, I argue that Mexicanization changed the significance of national sovereignty so that state intervention could be conceived of as acting for the benefit of private interests. This differed significantly from the discourse established by the oil nationalization, in which state intervention occurred on behalf of the public interest. The economic backlash and the conservative reaction that followed nationalization, however, changed the process by which the Mexican state asserted its control over mineral resources. When the administration of President Adolfo López Mateos began using the language of

\footnotetext{
${ }^{5}$ Sister Martin Byrne, "Cananea Consolidated Copper Company from Nationalization to Privatization: 1972-1991) International Journal of Public Administration 23, nos. 5-8, (2000): 563577; Anne Browning-Aiken, "The Transformation of Mexican Copper Miners: The Dynamics of Social Agency and Mineral Policy as Economic Development Tools," (PhD dissertation, University of Arizona, 2000), 326-327.

${ }^{6}$ Stephen Haber, "Anything Goes: Mexico's "New Cultural History,"” Hispanic American Historical Review 79, no. 2 (May 1999): 310.
} 
Mexicanization in 1960, it did so primarily to assuage the fears of private interests. The measure was presented as a nationalist maneuver that employed state intervention without being a direct form of nationalization. The Mexicanization Law signed by the president in 1961 modified the existing concessionary regime so that the ownership of mining companies had to consist of majority Mexican control. This requirement comprised the key innovation of Mexicanization and the key difference with its predecessor, which set it apart from nationalization. In contrast to direct ownership and management by the state, this policy led to the creation of parastate mining enterprises that permitted the involvement of the state, preserved the participation of foreign capital, and introduced the Mexican private sector into the mining industry.

This chapter focuses primarily on the passage of the Mexicanization Law in 1961. It begins by examining the legal basis of national sovereignty in article 27 of the 1917 Constitution and the concession theory of property. Then, the chapter looks at the application of article 27 during the nationalization of the oil industry in 1938, which became an exemplary assertion of national sovereignty. Next, the chapter examines how the conservative reaction came to influence the future process of Mexicanization. The remainder of the chapter, its final section, evaluates the causes, contexts, debates, and details of the Mexicanization Law of 1961 to ascertain how it reshaped the discourses related to national sovereignty, so that state intervention turned into a positive tool for private interests. 


\section{Article 27: Concession Theory of Property}

The 1917 Constitution was one of the most significant accomplishments of the Mexican Revolution. It contained a series of articles emblematic of the social character of the new regime and the newly asserted sovereignty of the Mexican nation. Article 27 is representative of such aspects. Although legitimized by myths related to labor's combativeness, the control of mineral resources was ultimately resolved through the state's assertion of national sovereignty over key natural resources in the new charter. Although the 1917 Constitution has been lauded for its progressive character, it also possessed a subtle conservative quality: by dealing with land and labor through two separate constitutional articles, the 1917 Constitution brought labor within the domain of the Mexican nation.

Article 27 of the 1917 Constitution provided the legal basis for asserting national sovereignty over mineral resources and embodied the "concession theory of property."' Paragraph four, for instance, established that the nation possesses "the direct dominion of all minerals or substances" residing in the subsoil. ${ }^{8}$ It further elaborated that "the direct dominion of the Nation is

\footnotetext{
${ }^{7}$ Maria Becerra González, Principios de la Constitución Mexicana de 1917: relacionados con el subsuelo, antecedents doctrinales y legislativos, principios fundamentales contenidos en la constitución en su versión original y cambios operados después de 1917 en el mismo texto constitucional (México, D.F.: Universidad Nacional Autónoma de México, 1967), 20, 56.

8 "Constitución Política de los Estados Unidos Mexicanos que Reforma la de 5 de Febrero del 1857," Diario Oficial: Organo del Gobierno Provisional de la República Mexicana, Tomo 5, no. 30, February 5, 1917, 150.
} 
inalienable and imprescriptible." ${ }^{\prime 9}$ The acquisition of mineral property for exploitation, then, occurred solely through the granting of temporary concessions by the state. These concessions were characterized by the "partial, limited, and revocable dispossession of things and rights belonging to the public domain for specific uses that are subordinated to the ends of general interest and are submitted to inspection by authorities."10 When President Cárdenas announced the nationalization of the oil industry in 1938, the measure nullified the conscessionary regime with respect to the nation's petroleum resources. The policy of Mexicanization in the 1960s represented a more accurate and direct application of article 27, preserving the concessionary regime despite significant modifications. ${ }^{11}$

\section{The Nationalization of the Oil Industry}

Early post-revolutionary governments focused their efforts on the control of Mexico's hydrocarbon resources. After two decades of failure, the nationalization of the oil industry on March 18, 1938, by President Lázaro

\footnotetext{
9 "Constitución Política de los Estados Unidos Mexicanos que Reforma la de 5 de Febrero del 1857. Diario Oficial: Organo del Gobierno Provisional de la República Mexicana, , Tomo 5, no. 30, February 5, 1917, 150.

${ }^{10}$ Becerra Gonzáles, Principios, 5, 59; María Becerra González, Derecho Minero de México y Vocabulario con Definición de Conceptos Jurídicos-Mineros (México, D.F.: Editorial LimusaWiley, 1963), 17, 47-48; Oscar Morineau, Los derechos reales y el subsuelo en Mexico. México, D.F..: Fondo de Cultura Económica, 1948); 230, 243; Francisco Arellano Rendón, El subsuelo mexicano: patrimonio nacional (México, D.F.: [s.n.], 1970), 11.

11 Secretaría de Gobernación, "Decreto que reforme los párrafos cuarto, quinto, sexto y séptimo, fracción I del artículo 27 y los artículos 42 y 43 de la Constitución Política de los Estados Unidos Mexicanos," Diario Oficial, January 20, 1960, 2.
} 
Cárdenas, became the fundamental expression of economic nationalism and the material culmination of the ideals of the Mexican Revolution and the 1917 Constitution. The nationalization was a strong unilateral state action, a political and economic maneuver to regain control of its resources that represented the end of a long struggle against colonialism and imperialism. In this context, an analysis of the process of nationalization reveals the unique contours of Mexicanization as a nationalist process.

Despite the proclamation of national sovereignty in the 1917 Constitution, early post-revolutionary governments were unable to take control of the oil industry. American and British companies began production in 1901 and controlled more than $90 \%$ of the industry until 1938 . Private Mexican capital "never accounted for more than 3 percent of the total."12 At their peak, American and British companies "pushed production to 193 million barrels annually by 1921, second only to...[production in] the United States."13 But, export-oriented production meant the benefits for Mexico were "limited exclusively to the payment of taxes, salaries, and lease rents." ${ }^{14}$ When the revolutionaries

\footnotetext{
12 Lorenzo Meyer, Mexico and the United States in the Oil Controversy, 1916-1942 (Austin: University of Texas Press, 1977), 5.

${ }^{13}$ Clayton R. Koppes, "The Good Neighbor Policy and the Nationalization of Mexican Oil: A Reinterpretation," Journal of American History 69, no. 1 (Jun., 1982): 64; Héctor Aguilar Camín and Lorenzo Meyer, In the Shadow of the Mexican Revolution: Contemporary Mexican History, 1910-1989, trans. Luis Alberto Fierro (Austin: University of Texas Press, 1993), 81.

${ }^{14}$ Meyer, Mexico and the United States, 5; Aguilar Camín and Meyer, In the Shadow of the Mexican Revolution, 150; Knight, "Introduction," in The Mexican Petroleum Industry in the Twentieth Century," eds. Jonathan C. Brown and Alan Knight, (Austin: University of Texas, 1992), ix.
} 
advanced the 1917 Constitution, article 27 provided the legal basis for nationalizing petroleum sources. In the words of a highly regarded historian, the Constitution thus became "the most important weapon used by the post-1917 administrations to challenge the hegemony of direct foreign investment."15 Nonetheless, in the next two decades Mexico remained unable to assert its own nationalist policies, and "foreign control of the oil industry. . [remained] one of the most contentious issues in foreign affairs." 16

When the Constitution was proclaimed, the inclusion of article 27 heightened the oil companies' concerns about property rights. In the years immediately after the revolution, American Senator Albert Fall extended the promise of recognition to the new Mexican regime in order to seek

guarantees against nationalization, a ban on the retroactive application of the measures established in the 1917 Constitution, recognition of the mining and oil rights acquired by U.S. citizens according to the laws of 1884,1892 , and 1909 , as well as the payment or retribution for all U.S. properties taken over after $1910 .^{17}$

President Obregón rejected the proposal, but Mexico's decline as an oil exporter after 1921 and the shift of investment to Venezuela and the Middle East, weakened the antagonism between the two countries. Consequently, the Bucareli Agreements of 1923 guaranteed the non-retroactive application of article

\footnotetext{
${ }^{15}$ Meyer, Mexico and the United States, xii-xiii, 232.

${ }^{16}$ Gilbert M. Joseph and Jürgen Buchenau, Mexico's Once and Future Revolution: Social Upheaval and the Challenge of Rule since the Late Nineteenth Century. Durham: Duke University Press, 2013), 132; Alan Knight, "The Politics of the Expropriation," in The Mexican Petroleum Industry in the Twentieth Century," ed. Jonathan C. Brown and Alan Knight (Austin: University of Texas, 1992), 90; Meyer, Mexico and the United States, 5.

${ }^{17}$ Aguilar Camín and Meyer, In the Shadow of the Mexican Revolution, 81.
} 
27 in exchange for the recognition of Obregón's government by the U.S. The Calles-Morrow agreement of 1928 solidified this guarantee, ended the pursuit of more substantial reform, and preserved the status quo of the oil companies. ${ }^{18}$

The impetus for change arrived during the presidency of Lázaro Cárdenas. After the presidency of Calles (1924-1928) and the informal continuation of his rule during the so-called Maximato (1928-1934), President Cárdenas revived the social, populist, and nationalist goals of the Mexican Revolution in December 1934. To repel political attacks from the pro-business Calles and build a base of mass support for his program of economic and social restructuring, Cárdenas advocated for broad union organization. Where the Constitutionalists had brought labor into the sphere of national politics during the 1910s, Cárdenas consolidated this effort when he incorporated labor into the structure of the revolutionary state. ${ }^{19}$

Upon coming to power, Cárdenas quickly signaled a nationalist policy with respect to oil. In his 1935 state of the union address, he indicated that national interests would prevail over foreign ones and hinted at ending "indiscriminate oil exports." ${ }^{20}$ The Cardenas government confirmed new concessions very slowly,

\footnotetext{
${ }^{18}$ Aguilar Camín and Meyer, In the Shadow of the Mexican Revolution, 82, 150; Robert F. Smith, The United States and Revolutionary Nationalism in Mexico, 1916-1932 (Chicago: University of Chicago Press, 1972), 221-222; Meyer, Mexico and the United States, 7, 232; Knight, "Introduction," Mexican Petroleum Industry, xii; Frank Brandenburg, The Making of Modern Mexico (Engelwood Cliffs: Prentice Hall, 1964), 272.

${ }^{19}$ Kevin J. Middlebrook, The Paradox of Revolution: Labor, the State, and Authoritarianism in Mexico (Baltimore: John Hopkins University Press, 1995), 87-93.

${ }^{20}$ Meyer, Mexico and the United States, 152-153.
} 
suspended tax exemptions, and the 1935 economic plan forecast an increase in domestic oil consumption. The government also began preparing a new tax law and new requirements for the active, regular production of mining properties. ${ }^{21}$ Even more alarming to foreign interests was the passage of the Expropriation Law of 1936. This law "gave the government the right to expropriate any property whatsoever for public use, compensation to be paid in accordance with its fiscal value within a maximum of ten years."22 The impetus for nationalization, however, came from another direction.

The catalyst for nationalization was a labor conflict. As part of his effort to increase worker unionization, Cárdenas had encouraged the creation of the national oil workers union, the Petroleum Workers' of the Mexican Republic (STPRM), in 1935 and its incorporation into the state-affiliated Confederation of Mexican Workers (CTM) in 1936. The following year, the STPRM initiated negotiations to establish the first collective contract between oil workers and foreign companies and requested an increase of 65 million pesos in wages and benefits. When the companies refused and tendered a counteroffer of 14 million pesos, a strike erupted. The movement quickly ended after the CTM requested the intervention of the federal labor board, the Federal Conciliation and Arbitration Board (JFCA), which sought to determine if the companies had

\footnotetext{
${ }^{21}$ Meyer, Mexico and the United States, 152, 156.

22 Meyer, United States and Mexico, 154; Aguilar Camín and Meyer, In the Shadow of the Mexican Revolution, 151; Secretaría de Gobernación, "Decreto que reforme los párrafos cuarto, quinto, sexto y séptimo, fracción I del artículo 27 y los artículos 42 y 43 de la Constitución Política de los Estados Unidos Mexicanos," Diario Oficial, January 20, 1960.
} 
resources to grant an increase. Meanwhile, a commission of cabinet members appointed by President Cárdenas levelled a general condemnation, saying that these companies had brought more harm than good to Mexico. Four months later, in December 1937, the labor board accepted the commission's recommendations and determined that the companies could afford an increase of more than 26 million pesos. ${ }^{23}$

On March 1, 1938, the Mexican Supreme Court affirmed the labor board's decision, but the companies remained intransigent. The Compañía Mexicana de Petróleo El Águila (“Mexican Eagle Oil Company”), founded and controlled by aristocratic Englishman Sir Weetman Pearson, offered 22 million pesos plus additional investment, while other companies began to close some operations and indicated their unwillingness to comply. At the same time, the national oil union threatened a national strike. On March 15, a week after the initial deadline passed, El Águila "reported that it would not comply with the decision of the labor board, which responded by suspending all contracts. With their pay suspended, and a strike deadline looming, workers began to seize loading terminals and shut down pipelines across all oil firms." 24 The possibility of industry disruptions threatened to reverberate across the whole economy. The companies' refusal to respect the laws and decisions of the courts challenged Mexican national

\footnotetext{
${ }^{23}$ Aguilar Camín and Meyer, In the Shadow of the Mexican Revolution, 151-152; Meyer, Mexico and the United States, 154-155, 158; Knight, "Introduction," Mexican Petroleum Industry, xiii.

${ }^{24}$ Author's italics. Noel Maurer, "The Empire Struck Back: Sanctions and Compensation in the Mexican Oil Expropriation of 1938," The Journal of Economic History 71, no. 3 (September 2011): 600-601.
} 
sovereignty and implied the possible collapse of Mexico's most important

industry. Facing these threats, President Cárdenas announced the

nationalization of the oil industry on March $18,1938 .{ }^{25}$

Scholars make a careful distinction between expropriation and

nationalization. Expropriation signified a takeover of a single company or group

of firms and implied a unique and limited occurrence that would have allowed for the continued economic participation of other foreign companies. United States officials considered "expropriation as analogous to eminent domain proceedings - a one-time condemnation of private property for a narrowly defined public purpose."26 Cárdenas's action more precisely followed the pattern of nationalization: "it was not individualized or directed at any particular firm; rather, it was a broad measure designed to bring about a basic change in the country's economic structure through takeover by the state."27 The nationalization of oil

\footnotetext{
${ }^{25}$ Meyer, Mexico and the United States, 152-153, 162-163, 166-167, 169; Maurer, "Empire," 600601; Aguilar Camín and Meyer, In the Shadow of the Mexican Revolution, 153; Lázaro Cárdenas, "IV Informe de Gobierno del Presidente Constitucional de los Estados Unidos Mexicanos Lázaro Cárdenas del Río $1^{\circ}$ de septiembre de 1938," in Informe del Presidente Lázaro Cárdenas (México, D.F.: Centro de Documentación, Información y Análisis, 2006), 88; "Decreto que expropia a favor del patrimonio de la Nación, los bienes muebles e inmuebles pertenecientes a las compañías petroleras que se negaron a acatar el laudo de 18 de diciembre de 1937, del Grupo Número 7 de la Junta Federal de Conciliación y Arbitraje," Diario Oficial, March 18, 1938; Manuel Martínez Sicilia, "Contestación al Sexto Informe de Gobierno del President Constitucional de los Estados Unidos Mexicanos Lázaro Cárdenas del Río, por parte del Diputado Manuel Martínez Sicilia XXXVIII Legislatura. $1^{\circ}$ de septiembre de 1940," in Informe del Presidente Lázaro Cárdenas (México, D.F.: Centro de Documentación, Información y Análisis, 2006), 141. Lázaro Cárdenas, "VI Informe de Gobierno del Presidente Constitucional de los Estados Unidos Mexicanos Lázaro Cárdenas del Río $1^{\circ}$ de septiembre de 1940," in Informe del Presidente Lázaro Cárdenas (México, D.F.: Centro de Documentación, Información y Análisis, 2006), 135.

26 Koppes, "Good Neighbor Policy," 68.

${ }^{27}$ Meyer, Mexico and the United States, 169.
} 
took over an entire resource and the administration of an entire industry, and in the process foreclosed the possibility of any foreign participation in that sector of the economy. It was this possibility that motivated the oil companies to defy Mexican courts and Mexican national sovereignty. ${ }^{28}$

Challenges on several fronts threatened the success of nationalization. Armed intervention into Latin America and Mexico by the United States had been a regular occurrence in the nineteenth and early twentieth centuries. The Good Neighbor Policy, and more importantly, the intimations of global conflict mitigated the American response. With respect to the growing conflict in Europe, President Franklin Roosevelt's main concern focused on preventing the incursion of fascism into Latin America and solidifying an inter-American alliance. Policy makers in the United States recognized the need for caution, concerned that stronger action would produce economic and political instability, potentially driving Mexico toward alliances with fascist countries and ultimately doing more harm than good for United States interests. When the Second World War erupted in 1939, the State Department brokered an agreement with the Mexican government without the participation of the oil companies, ${ }^{29}$ and yielded to "Mexican national sovereignty over the interests of American oil companies." 30

\footnotetext{
28 Koppes, "Good Neighbor Policy," 66-67; Maurer, "Empire," 601.

${ }^{29}$ Meyer, Mexico and the United States, 186, 192, 215; Aguilar Camín and Meyer, In the Shadow of the Mexican Revolution, 155; Koppes, "Good Neighbor Policy," 70; Maurer, "Empire," 605.

${ }^{30}$ Aguilar Camín and Meyer, In the Shadow of the Mexican Revolution, 155.
} 
Before the agreement had been made, the United States replaced armed intervention with various forms of economic coercion to defend its private property interests abroad. After the labor board's ruling in 1937, the American government and the oil companies began spreading propaganda, suspending sales, and withdrawing bank deposits to encourage capital flight and to aggravate an already existing economic crisis. After March 1938, the companies would have preferred the State Department's help in "the establishment of a conservative, even fascist, government through a coup d'état." ${ }^{31}$ Instead, Secretary of State Cordell Hull attacked the legitimacy of Mexican courts by measuring it against the rulings of international law, arguing that the Mexico had failed to provide "prompt, effective, and adequate indemnity." ${ }^{32}$ At the same time, the U.S. set tough conditions on economic aid while obstructing intergovernmental and private loans. The United States Department of the Treasury altered the handling of silver purchases, which had brought the Mexican government more revenue than oil, by changing contracts from longterm to short-term agreements that had to be renewed on a month-to-month basis. $^{33}$

\footnotetext{
${ }^{31}$ Meyer, Mexico and the United States, 180-181.

32 Meyer, Mexico and the United States, 191.

${ }^{33}$ Meyer, Mexico and the United States, 162-166, 187-188, 191, 194, 201-203, 207, 209; Aguilar Camín and Meyer, In the Shadow of the Mexican Revolution, 152, 154; Koppes, "Good Neighbor Policy," 66, 69.
} 
The most severe threat came from the boycott imposed by the oil companies. With the State Department's help, sales of oil were limited to Brazil, Chile, Cuba, Guatemala, Nicaragua, Uruguay, Panama, and Paraguay. For a short time, until the beginning of the Second World War, Mexico exported oil to Germany, Italy, and Japan as well. After conflict erupted in 1938, these trading arrangements unraveled. The American companies blocked imports of machinery and chemicals and hindered the operations of railroads and ocean tankers. The departure of specialized personnel also increased the burdens of a small group of Mexican technicians tasked with maintaining "the enormous industrial complex" undertaking its reorganization into a single centralized stateoperated enterprise. ${ }^{34}$

Despite American attempts to block it, the effort to nationalize the oil industry survived. Global conflict and the resolution agreed on between the Mexican government and the British Sinclair Oil Company in 1940, pushed American officials to act without the participation of the American companies. They agreed that the companies would not return to Mexico and that compensation of 40 million dollars would be made in cash and oil over several

\footnotetext{
${ }^{34}$ Meyer, Mexico and the United States, 178, 200-203, 205, 209; Aguilar Camín and Meyer, In the Shadow of the Mexican Revolution, 155; Fabio Barbosa Cano, "Technical and Economic Problems of the Newly Nationalized Industry," in The Mexican Petroleum Industry in the Twentieth Century, eds. Jonathan C. Brown and Alan Knight, (Austin: University of Texas, 1992), 190-191; Manuel Avila Camacho, "I Informe de Gobierno del President Constitucional de los Estados Unidos Mexicanos Manuel Avila Camacho $1^{\circ}$ de septiembre de 1941," in Informe del Presidente Manuel Avila Camacho (México, D.F.: Centro de Documentación, Información y Análisis, 2006), 171.
} 
years. ${ }^{35}$ In 1942, Deputy Manuel Gudiño described Cárdenas's maneuver as "the most audacious and courageous. . . since it challenged the wrath and immense strength of the most powerfully organized wing of capitalist imperialism."36 The achievement of national sovereignty represented the success of a strong state at acquiring and administering its own natural resources. Now, Cárdenas proclaimed, they were "for the [Mexican people's] defense, conservation, development, and use."37 The maneuver represented the material embodiment of revolutionary nationalism. The Cardenista period, highlighted by the nationalization of the oil industry, has been interpreted as "the most progressive phase of the Mexican Revolution." 38 The one that came next would be significantly different.

\section{The Conservative Reaction}

Paradoxically, Cardenista policies marked both the climax and end of the Mexican Revolution. The nationalization produced a conservative reaction that altered the political dynamics of post-revolutionary Mexico. Conservative groups of various types and inclinations, scattered across the country, unified around

\footnotetext{
${ }^{35}$ Maurer, "Empire," 604, 610; Meyer, Mexico and the United States, 153, 169-170, 182, 220-221; Koppes, "Good Neighbor Policy," 73.

${ }^{36}$ Manuel Gudiño, "Contestación al Segundo Informe de Gobierno del President Constitucional de los Estados Unidos Mexicanos," in Informe del Presidente Manuel Avila Camacho (México, D.F.: Centro de Documentación, Información y Análisis, 2006), 238.

${ }^{37}$ Lázaro Cárdenas, "VI Informe de Gobierno," 135.

${ }^{38}$ Joseph and Buchenau, , Mexico's Once and Future Revolution, 118.
} 
their concern over nationalization and its exclusion of the private sector. These groups threatened the survival of the revolution and prompted a reversal of Cárdenas's progressive policies, particularly the effort to incorporate labor and peasantry as distinct groups into the national fabric of the country. ${ }^{39} \mathrm{He}$ disassociated himself from socialism and halted additional nationalization plans in order to appease the private sector and regain the favor of foreign investors. Although strategic in intent, Cárdenas's retreat has been interpreted as signaling the true close of the Mexican Revolution. ${ }^{40}$

The conservative reaction formalized itself during the presidential election of 1940. Exemplifying this reactionary trend, General Juan Andreu Almazán announced his candidacy for the Partido de la Revolución Mexicana's (PRM) nomination, which threatened to destroy the political stability gradually built up in post-revolutionary Mexico. Against this threat, Cárdenas relinquished his initial choice of successor, Francisco J. Múgica, who represented the continuation of Cardenista policies but whose victory would have pushed Almazán toward open rebellion. So, Cárdenas transferred his patronage to an alternate candidate, General Manuel Avila Camacho, whom he considered "as conservative as Almazán but whom he felt he could try to commit up to a certain point to the administration's program." ${ }^{41}$ Avila Camacho was also liked by the United States,

\footnotetext{
${ }^{39}$ Meyer, Mexico and the United States, 227-228; Joseph and Buchenau, 133.

${ }^{40}$ Aguilar Camín and Meyer, In the Shadow of the Mexican Revolution, 156, 158; Meyer, Mexico and the United States, 227-228; John Sherman, The Mexican Right: The End of Revolutionary Reform (Westport, Conn.: Praeger, 1997), xii, 80, 101.

${ }^{41}$ Meyer, Mexico and the United States, 177.
} 
and regarded as more moderate than Cárdenas and Almazán, who was considered too reactionary and had associated with fascist sympathizers. Almazán eventually lost the election but never launched a rebellion. ${ }^{42}$

Despite Almazán's defeat, the election of President Manuel Avila Camacho began Mexico's pivot toward a more conservative orientation. The presidency of his successor Miguel Alemán (1946-1952), redefined the character of Mexico for the subsequent decades:

presidential absolutism, one-party monopoly on power, manipulation of mass organizations, the promotion of a nationalist unifying ideology in place of class and ideological differences, the elimination of the political Left from the official coalition, and state domination of the labor movement....[It] also signified the ascent of a conservative postrevolutionary oligarchy of financiers, businessmen, and industrialists. ${ }^{43}$

Whereas Cardenista policies focused on labor, agrarian, and nationalist reforms to serve popular interests; Alemán's policies favored the interests of private and foreign investors. Where the proponents of revolutionary nationalism argued that social justice needed to be implemented alongside economic development, Alemán's supporters regarded the creation and accumulation of economic wealth as "the better path to strengthen and consolidate national sovereignty and development." ${ }^{44}$ The state continued to intervene in the economy, but in order to

\footnotetext{
${ }^{42}$ Meyer, Mexico and the United States, 176-177; Joseph and Buchenau, Mexico's Once and Future Revolution, 138.

43 Joseph and Buchenau, Mexico's Once and Future Revolution, 148.

${ }^{44}$ Elisa Servín, "Los "enemigos del progreso:" crítica y resistencia al desarrollismo del medio siglo," in Del nacionalismo al neoliberalismo, 1940-1994, ed. Elisa Servín (México, D.F.: Fondo de Cultura Económica, 2010), 80-81.
} 
facilitate the private sector's businesses rather than to operate as a direct owner and producer on behalf of the Mexican people. Just as significant as that of Cárdenas, Alemán's presidency transformed the political, economic, and cultural dynamic in Mexico, and exemplified the growing fissures and contradictions between revolutionary nationalism and the ruling party. ${ }^{45}$

\section{The Mexicanization of the Mining Industry, 1961}

Decades since the strike in Cananea, and centuries since the advent of colonial mineral exploitation, Mexico asserted national sovereignty over its mineral resources through the policy of Mexicanization. According to Juan Luis Sariego, Mexicanization challenged the entrenched orientation toward mining export production and foreign markets, with the goal of "recover[ing] under the control of the nation the property, the administration, the exploitation and the reorientation of the mineral resources of the country." 46 President Adolfo López Mateos signed the Ley Reglamentaria del Artículo 27 Constitucional en materia de explotación y aprovechamiento de recursos minerales, or Ley de mexicanización de la minería, on February 5, 1961. This represented the

\footnotetext{
${ }^{45}$ Meyer, Mexico and the United States, 177; Servín, "Enemigos del progreso," 122; Knight, "Introduction," Mexican Petroleum Industry, xiv; Elisa Servín, "Introducción," in Del nacionalismo al neoliberalismo, 1940-1994, ed. Elisa Servín (México, D.F.: Fondo de Cultura Económica, 2010), 12; Buchenau and Joseph, Mexico's Once and Future Revolution, 155; Aguilar Camin, 162. Ramon Eduardo Ruiz, Mexico: Why a Few are Rich and the People Poor (Berkeley: University of California Press, 2010), 148; Paul Gillingham and Benjamin T. Smith, "Introduction: The Paradoxes of Revolution," in Dictablanda: Politics, Work, and Culture in Mexico, 1938-1968, eds. Paul Gillingham and Benjamin T. Smith (Durham: Duke University Press, 2014).

${ }^{46}$ Sariego et al., El estado, 15-16, 360.
} 
culmination of nationalist mineral policy, yet in contrast to the oil nationalization, it emerged as a much more moderate and conservative approach. It was also a more complex and subtle process that reflected the experiences of 1938 and the changed political culture of Mexico after the conservative reaction. Rather than a direct takeover of an entire industry, the main stipulation of Mexicanization required that a majority of a mining company rest in the hands of Mexican nationals. This led to the creation of parastate enterprises, which permitted the involvement of the state, preserved the participation of foreign capital, and introduced the Mexican private sector into the mining industry. ${ }^{47}$ The meaning of national sovereignty had changed remarkably since 1938 , so that state intervention operated on behalf of private interests rather than public ones.

Early nationalist policies in the mining industry had been limited to fiscal measures. The governments of Alvaro Obregón and Plutarco Elías Calles attempted to establish "a nationalist-style mining legislation according to the postulates of the Constitution," ${ }^{88}$ but they were hindered from implementing more substantial reform due to post-revolutionary reconstruction efforts in addition to industry and market pressures. Throughout the 1920s, the continued ownership by foreign investors and dependence on foreign markets precluded significant structural reform and, as stated before, reduced nationalist efforts to fiscal measures. ${ }^{49}$

${ }^{47}$ Sariego et al., El estado, 15-16, 147.

${ }^{48}$ Sariego et al., El estado, 68.

${ }^{49}$ Sariego et al., El estado, 25, 63, 65, 68-71, 145. 
Preceding Mexicanization, the mining industry suffered more than two decades of stagnation. According to some scholars, the industry's decline began after the oil nationalization when the loss of financing from international sources led to the absence of investment, exploration, and technological innovation in the late 1930 s. $^{50}$ The Second World War and the Korean War alleviated these trends for brief periods but failed to eliminate their long-term causes, the symptoms of which included diminished exports and reduced revenues for the government. As foreign investors pursued minerals and more dynamic economic sectors beyond Mexico and Latin America, the main problem remained "the constant absence of sufficient new investments." M1 Meanwhile, the crisis reverberated into other industries, restricting the supply of minerals essential to domestic industries that had emerged under the import-substitution policies of the 1940 s. ${ }^{52}$

Lawmakers and bureaucrats regarded the main cause of stagnation to lie in the concentration and hoarding of mining concessions. In 1960, Alfredo Valtierra, director of Mines and Petroleum, a sub-division of the Secretary of National Patrimony, claimed that $85 \%$ of the mining industry remained under the control of foreign enterprises and served foreign economies while contributing

\footnotetext{
${ }^{50}$ Robert B. Wallace Hall, La dinámica del sector minero en México, 1877-1970 (México: El Colegio de México, 1972), iii-iv.

51 Wallace Hall, La dinámica del sector minero, 107.

52 Wallace Hall, La dinámica del sector minero, 109, 111; Sariego et al., El estado, 11, 184, 186; Sariego, Enclaves, 297-299.
} 
little to the long-term development of Mexico. Concession holders were amassing mining concessions without engaging in active production, and thus, failing to provide raw materials for industrialization, currency for foreign exchange, or new sources of employment. Senator Manuel Moreno Sánchez argued that mining concessions had been granted with the expectation that concession holders would develop them. Unproductive concessions, he argued, were one of the key problems that contributed to the industry's stagnation and to related social problems. ${ }^{53}$

Legislative efforts to address problems in the mining industry began in the mid-1950s. On October 30, 1953, the First Senate Commission of Mines headed by Senator Alberto Terrones Benítez offered three solutions: fiscal reform, bureaucratic reform, and constitutional reform. ${ }^{54}$

As in the 1920s, mining legislation tended toward the most politically feasible or expedient route. Fiscal policy remained the primary pivot in the relationship between the state and mining companies and constituted the most direct form of state intervention. Supporters of fiscal reform argued that the existing tax structure had become too burdensome. Tax reductions would lower costs, increase earnings, and prompt the recovery of mining. The Cámara

\footnotetext{
${ }^{53}$ Manuel Moreno Sánchez, "Sobre el Proyecto de Ley Orgánica del Artículo 27 Constitucional en Materia de Explotación y Aprovechamiento de Recursos Minerales," Diario de los Debates de la Cámara de Senadores del Congreso de los Estados Unidos Mexicanos, Año III, Legislatura XLIV, Periodo Ordinario, Tomo III, Número 33. México, D.F.: December 21, 1960. http://infosen.senado.gob.mx/documentos/DIARIOS/1960_08_221960_12_30/1960_12_21_O.pdf (Accessed May 8, 2016), 11-12.

54 “Se Acometerá Este Año la Total Reforma de las Leyes Minera," Excélsior, November 3, 1955.
} 
Minera, a group representing the mining industry, requested reductions in taxes applied to rent, earnings, imports, exports, and production. The Ley de Impuestos y Fomento a la Minería (Law on Mining Taxes and Development 1955) eventually reduced taxes on exports and production and included the possibility of limited fiscal arrangements. It also increased subsidies to small- and medium-sized mining enterprises. Without altering the structure of the mining industry, it "represented a political compromise with powerful international mining interests." ${ }^{55}$ When the industry failed to improve, the representatives of business interests called for the elimination of all mining taxes. Persistent stagnation also renewed calls from Senator Terrones Benítez in September 1956 and June 1957 for a more substantial reform that departed from fiscal policy. ${ }^{56}$ These calls were answered by the new president.

After three conservative presidencies, the election of Adolfo López Mateos in 1958 resurrected a more nationalist stance but prompted careful negotiations among political forces on both the left and the right. When Miguel Alemán became president in 1946, he moved the country to the right by realigning the

\footnotetext{
${ }^{55}$ Wallace Hall, La dinámica del sector minero, 140; Secretaría de Hacienda y Crédito Público, "Ley de Impuestos y Fomento a la Minería," Diario Oficial, Tomo CCXIII, Num. 53, December 31, $1955,13-20$.

${ }^{56}$ Sariego et al., El estado, 14; Wallace Hall, La dinámica del sector minero, 111, 113; "En Defensa de la Industria Minera," Excélsior, November 4, 1955; "Se Acometerá Este Año la Total Reforma de las Leyes Minera," Excélsior, November 3, 1955; "Buen Resultado de la Nueva Ley de Minería," Excélsior, January, 7 1956; "La Nueva Ley de Minería Impulsa esa Actividad, Afirma el Ing. Serrano," El Nacional, January 7, 1956; "Aun Cuando la Nueva Ley Mejora la Minería, su Problema Sigue en Pie." El Universal, March 23, 1956; "La Ley Minera Requiere Simplificación Urgente," Novedades, June 8, 1957; "No se ha Obedecido Importante Acuerdo del Senado de la República," El Universal, September 6, 1956; "Nadie se Ocupa ya del Dominio del Subsuelo," Excélsior, September 6, 1956.
} 
state with pro-business factions, and by reducing the power of the left and of labor as independent political forces. In a speech to the CTM, Alemán stated:

Private enterprise should have complete freedom and be able to count on support from the state, so long as it acts on behalf of the general interest. Property ownership should preferably be in the hands of Mexican citizens. .. but foreign capital that comes to unite its destiny with that of Mexico will be able to freely enjoy its legitimate profits. ${ }^{57}$

Moving away from the pro-state position of Cárdenas, Alemán opened the door to private and foreign interests as viable partners in the alleged pursuit of Mexican nationalism.

New business partners required the evisceration of the left and the labor movement which had been empowered by Cárdenas, an effort aided by the political climate of the Cold War. The Partido Revolucionario Institucional (PRI) denounced communism as an imperialist doctrine: "Anti-communism thus became identified with anti-imperialism and, at bottom, with the affirmation of Mexican nationalism." ${ }^{58}$ While accepted by pro-government unions, this stance was opposed by "unions in the public sector, especially in nationalized industries, whose workers tended to identify national sovereignty with an anti-imperialist opposition to foreign investment." ${ }^{\text {59 }}$

The control of labor was resolved through an event known as the charrazo. During a railway workers strike that began in 1948, the government

\footnotetext{
${ }^{57}$ Peter H. Smith, "Mexico since 1946: Dynamics of an Authoritarian Regime," in Mexico since Independence, ed. Leslie Bethell (Cambridge: Cambridge University Press, 1991), 339.

58 Smith, "Mexico since 1946," 342.

59 Smith, "Mexico since 1946," 343.
} 
supported Jesús Díaz de León over a dissident leader, Luis Gomez Z. who had created a separate union federation, the Unitary Confederation of Workers (CUT) in opposition to the state-affiliated CTM. Of the two leaders, Díaz de León was more amenable to resolving the conflict and signed a contract permitting the firing of over 2,000 railroad employees. His became the model for controlling labor: "docile labor leadership would sell out the interests of its members and receive, in return, political backing (and financial benefits) from the state and/or management." 60 This strategy effectively ended the existence of independent unions and consolidated labor's support for the ruling party. ${ }^{61}$ This behavior became manifest in 1960 when the leader of the national mining union, Napoleón Gómez Sada, acquiesced to the government's position on Mexicanization rather than taking a more radical stance.

The state's realignment toward business, and the decline of both the autonomy of the left and the labor movement weakened the legitimacy of the PRI. President López Mateos attempted to restore the revolutionary legitimacy of the PRI by emphasizing his nationalist principles. On July 1, 1959, he proclaimed himself at "the extreme left within the limits set by the Constitution." 62 He also asserted Mexico's diplomatic independence during the Cold War by maintaining the anti-communist position adopted by Alemán while expressing

\footnotetext{
60 Smith, "Mexico since 1946," 343.

${ }^{61}$ Middlebrook, 135-147.

62 Joseph and Buchenau, Mexico's Once and Future Revolution, 158-159.
} 
support for the Cuban Revolution in solidarity with the Mexican Revolution. ${ }^{63}$ When Mexicanization appeared on the horizon in 1960, however, its primary audience was not the left nor the working class but rather the pro-business forces on the right. After the conservative reaction to nationalization in 1938, the Mexican state eventually adopted a different tactic.

Conservative forces, weakened and dispersed since the revolution, had coalesced in opposition to Cárdenas. Indication of this shift became apparent with the creation of the right-leaning Partido de Acción Nacional (PAN) and the strengthening of business interest groups including the Employers Confederation of the Mexican Republic (COPARMEX), the Confederation of Industrial Chambers (CONCAMIN), and the National Confederation of Chambers of Commerce (CONCANACO). ${ }^{64}$ Business and the private sector had been shut out from the reorganizations of the ruling party by Cárdenas and by Alemán, but their exclusion from the corporate structure of the state belied their growing power and influence through informal means. Jorge Legorreta, for example, chairman of the Banco Nacional de México also sat on the boards of Nacional Financiera, and the Compañía Minera de Cananea (see chapter 4). As government policies contributed to the rising strength of the private sector, the private sector increasingly used its growing power to oppose the government

\footnotetext{
63 Smith, "Mexico since 1946," 355.

${ }^{64}$ Sherman, Mexican Right, 109-110; Ricardo Tirado, "Semblanza de las organizaciones empresariales mexicanas," in Grupos económicos y organizaciones empresariales en México, ed. Julio Labastida (México, D.F.: Biblioteca Iberoamericana, 1986), 163-164.
} 
when it acted against their interests. After President Adolfo Ruíz Cortines (19521958) lowered the price of food staples in the early 1950 s, the private sector responded by reducing investment and engaging in capital flight. ${ }^{65}$ So when López Mateos announced that he was on the extreme left of the Constitution, "[c]onservative entrepreneurs and journalists reacted. . . with indifference, knowing full well that the PRI machine would keep the nation on its pure path of state-sponsored capitalist development." 66 The greatest challenge to substantive mining reform was the potential threat posed by the private sector.

The institutional alignment of the state and private interests materialized in the Secretary of National Patrimony (SEPANAL), created less than a month after the new president's inauguration. ${ }^{67}$ The new ministry combined the duties of two previous departments - the Secretary of Commerce and Industry, originally granted oversight of the mining industry in March $31,1917,{ }^{68}$ and the Secretary of National Properties and Administrative Inspection, created on December 7 , 1946, which provided for the conservation and protection of national properties. ${ }^{69}$ SEPANAL was charged with executing and realizing the principles of article 27 of

\footnotetext{
65 Smith, "Mexico since 1946," 348.

${ }^{66}$ Joseph and Buchenau, Mexico's Once and Future Revolution, 159.

67 Joseph and Buchenau, 159; Meyer, Mexico and the United States, 263; Sariego et al., El estado, 186-187, 250-251; Teodoro Hernández, "Hacia un Régimen de Positiva Recuperación Nacional," El Nacional, May 29, 1960.

68 "La Nueva Ley de Secretarías," Diario Oficial, December 31, 1917.

69 Secretaría de Gobernación, "Ley de Secretarías y Departamentos de Estado," Diario Oficial, December 21, 1946.
} 
the 1917 Constitution. ${ }^{70}$ President López Mateos argued that its duties were to "to regulate the use of natural resources and of private property, as well as establishing the modalities that dictate the public interest." ${ }^{71}$ SEPANAL also received the authority to "reclaim national property," ${ }^{12}$ to achieve its stated goal, according to López Mateos, "to promote, supply, develop, and strengthen the efforts of private initiative."73

When the Secretary of National Patrimony advanced its proposal to reform the mining industry, it did so through a policy that came to be known as Mexicanization. The origins of the term remain unclear, but it seemingly made its first public appearance in the 1946 book La historia de la mexicanización de los ferrocarriles nacionales de México (The History of the Mexicanization of the National Railways of Mexico) by Servando A. Alzatí. During the Porfiriato, foreign investment became central to the government's economic policy. The success at attracting foreign involvement in the railroad industry, increasing the total rail mileage from 416 miles in 1876 to 7,681 miles by 1898 , prompted fears of imperialist encroachement by American companies and motivated government

\footnotetext{
70 "Dictamen de las Comisiones Unidas Primera y Segunda de Gobernación y, Primera de Puntos Constitucionales y Primera Sección de Estudios Legislativos, que se refiere a la iniciativa de Ley de Secretarías y Departamentos de Estado, enviada por el C. Presidente de la República," Diario de los Debates de la Cámara de Senadores del Congreo de los Estados Unidos Mexianos, Año I, Legislatura XLIV, Periodio Ordinario, Tomo I, Núm. 30, p. 4

71 "Dictamen de las Comisiones Unidas Primera," Diario de los Debates, 41.

72 Secretaría de Gobernación, "Ley de Secretarías y Departamentos de Estado," Diario Oficial, Tomo CCXXXI, núm. 44, December 24, 1958, 4.

73 "Dictamen de las Comisiones Unidas Primera," Diario de los Debates, 41.
} 
officials to reduce the role of foreign capital and increase Mexican control. In 1898, finance minister José Yves Limantour (1893-1911), initiated the policy that Alzati would later call, in 1935, Mexicanization. Limantour did not refer to his own policy as Mexicanization but its major characteristics - majority control of the new National Railways of Mexico, the institutionalized use of Spanish in the industry, and the replacement of foreign workers with Mexicans - became the hallmark features of future nationalist efforts that would fall under that name. ${ }^{74}$

With respect to its legislative precedents, Mexicanization had its origins in Article 27 of the 1917 Constitution. According to the law, "Only Mexicans by birth or by naturalization and Mexican corporations," could acquire concessions to exploit natural resources. ${ }^{75}$ Foreign entities could receive concessions by permission from the Secretary of Foreign Relations and would be considered Mexican nationals for such purposes and restricted from seeking any recourse to their home governments. These requirements were modified in 1944 to regulate the movement of foreign capital in Mexico during the Second World War. To prevent the potential disruption caused by the inflows and outflows of capital, the law required $51 \%$ of a company's total ownership to be in the hands of Mexican

\footnotetext{
${ }^{74}$ Robert W. Randall, "Mexico's Pre-Revolutionary Reckoning with Railroads," The Americas 42, no. 1 (July 1985), 20, 25-27; Gerald Theisen, "La mexicanización de la industria en la época de Porfirio Díaz," Foro Internacional 12, no. 4 (April-June 1972): 503.

75 "Constitución Política de los Estados Unidos Mexicanos que Reforma la de 5 de Febrero del 1857," Diario Oficial: Organo del Gobierno Provisional de la República Mexicana, Tomo V, no. 30, February 5, 1917, 151.
} 
owners. ${ }^{76}$ According to John Sherman, the law was never enforced but used to solidify an alliance between Mexican and United States business interests. ${ }^{77}$

The process of drafting, revising, and debating the Mexicanization Law of 1961 consisted of nationalist efforts to permit state intervention in the mining industry while assuaging the concerns of the conservative, pro-business sector. The first legislative step toward the Mexicanization law of 1961 was the revision of the Constitution's Article 27. ${ }^{78}$ Previously, Senator Alberto Terrones Benítez had expressed that mining reform needed to include constitutional reform. Persistent stagnation proved the failure of fiscal measures alone and confirmed the need for more substantial reform. ${ }^{79} \mathrm{He}$ argued that Article 27 permitted a more active participation of the state in the mining industry. Senator Terrones initially proposed a strong role for the state, allowing it to make direct use of minerals in an industrial or commercial capacity. ${ }^{80}$ The constitutional reform signed into law on January 20, 1960 was more subtle. The original version of Article 27 stated that concessions could be granted to "individuals, or civil or

\footnotetext{
${ }^{76}$ Secretaría de Relaciones Exteriores, "Decreto que establece la necesidad transitorio de obtener permiso para adquirir bienes, a extranjeros y sociedades mexicanas que tengan o tuvieren socios extranjeros," Diario Oficial, Tomo CXLV, núm. 6, July 7, 1944, 2-3.

77 John W. Sherman, "The Mexican "Miracle" and Its Collapse," in The Oxford History of Mexico, eds. Michael C. Meyer and William H. Beezley (Oxford: Oxford University Press, 2000), 582.

${ }^{78}$ Wallace Hall, La dinámica del sector minero, 139.

79 “La Ley Minera Requiere Simplificación Urgente," Novedades, June 8, 1957.

80 "Insistirán en la Reforma, al Art. 27," Novedades, November 3, 1955; "La Ley Minera Requiere Simplificación Urgente," Novedades, June 8, 1957; "Nadie se Ocupa ya del Dominio del Subsuelo," Excélsior, September 6, 1956; "Se Acometará Este Año la Total Reforma de las Leyes Mineras," Excélsior, November 3, 1955.
} 
commercial corporations constituted in accordance with Mexican law. ${ }^{81}$ The 1960 revision changed this to "individuals or corporations constituted in accordance with Mexican law." ${ }^{22}$ This apparently minor revision actually broadened the spectrum of mining enterprises, making room for state participation in the mining industry. ${ }^{83}$

Shortly after the January reform, SEPANAL began drafting the Mexicanization law. At the end of September 1960, Secretary Eduardo Bustamente began campaigning on its behalf, initiating a period of debate and revision. A group of senators introduced the draft on December 1, 1960 and turned over the project to the United Commissions of Legislative Studies, Second of Mines, and of Properties and National Resources. ${ }^{84}$ From December 7 to December 10, 1960, the commissions hosted a series of public forums, or, audiencias, during which a total of eighteen representatives from various organizations presented their arguments for and against the Mexicanization law.

\footnotetext{
81 "Constitución Política de los Estados Unidos Mexicanos que Reforma la de 5 de Febrero del 1857," Diario Oficial: Organo del Gobierno Provisional de la República Mexicana, Tomo 5, no. 30, February 5, 1917, 151.

82 Secretaría de Gobernación, "Decreto que reforme los párrafos cuarto, quinto, sexto y séptimo, fracción I del artículo 27 y los artículos 42 y 43 de la Constitución Política de los Estados Unidos Mexicanos," Diario Oficial, January 20, 1960, 2.

${ }^{83}$ Constitución Política de los Estados Unidos Mexicanos que Reforma la de 5 de Febrero del 1857." Diario Oficial: Organo del Gobierno Provisional de la República Mexicana, Tomo 5, no. 30, February 5, 1917, 151; Secretaría de Gobernación, "Decreto que reforme los párrafos cuarto, quinto, sexto y séptimo, fracción I del artículo 27 y los artículos 42 y 43 de la Constitución Política de los Estados Unidos Mexicanos," Diario Oficial, January 20, 1960, 2.

${ }^{84}$ Mexican Senate, "Lectura," Diario de Senadores, December 1, 1960, 5; "Primer Paso Para que la Riqueza Minera del País Pertanezca del Todo a México," Excélsior, December 2, 1960.
} 
Opponents of Mexicanization leveled numerous arguments against state intervention. Engineer Máximo Muñoz argued that the state was too inadequate to "encompass and administer. . . an industrial organization so complex as mining in its diverse phases of exploration, production and commerce." 85 Senator Hilario Medina Goana argued that the proposed law was unconstitutional, because it would lead to the creation of what he called a "Mining State." ${ }^{86}$ New restrictions on concessions were not provided for in the 1917 Constitution and would restrict the availability of mineral resources to companies. He acknowledged that the Mexican state had the constitutional right to grant concessions but not to act as an "entrepreneur" or participate in the "direct exploitation of mines." 87

Many opponents argued that the law would fail to realize its objectives, largely by inhibiting the participation of domestic and foreign capital in the mining industry. Deputy Enrique Sámano Salgado claimed that the high capital requirements of larger mining enterprises, even at $51 \%$, would prohibit the creation of new companies. Ownership requirements and the obligations of concession holders were also considered too burdensome for Mexican investors who possessed fewer capital resources and less access to technology than their

\footnotetext{
85 Ing. Máximo Muñoz, “La Nueva Ley Minera,” Excélsior, December 26, 1960.

86 "Opiniones en pro y en Contra de la Ley Minera Escucháronse Ayer en el Senado," Excélsior, December 10, 1960.

${ }^{87}$ Hilario Medina Goana, "Sobre el Proyecto de Ley Orgánica," Diario de Senadores, 5-7, 9, 10; "El Senado Aprobó en lo General, la Ley de Recursos Minerales," El Nacional, December 22, 1960.
} 
foreign counterparts. Senior Engineer Alfonzo Martínez Berges argued that the most experienced and knowledgeable group of people in the industry, mining entrepreneurs, would be alienated. Foreign investors were inhibited from Mexicanizing existing companies or entering into new mining ventures in which they would have minority participation. Eduardo Prieto López argued that the new obligations proposed in the law would discourage sources of private investment and require stronger intervention by the state. The subsequent nationalization would alienate private investors and strain the national budget, ultimately leading to the collapse of the mining industry as well as the Mexican state. ${ }^{88}$ Some argued that Mexicanization would be unachievable without incentives. Sámano Salgado observed that the law contained no "specific means

\footnotetext{
88 "Cuatro Oradores en la Audiencia Pública Minera," Excélsior, December 11, 1960; "Mexicanizar las Minas: Firme Tesis del Senado," Excélsior, December 14, 1960; "El Senado Sigue las Audiencias Sobre la Minería," El Nacional, December 10, 1960; "El Capital Extranjero Sólo Como Auxiliar en la Minería," Excélsior, December 10, 1960. Raimundo Guzman Rojas, "Debatido Proyecto" Novedades, December 27, 1960; Secretaría de Industria, Comercio y Trabajo, August 7, 1930. Diario Oficial, "Ley Minera de los Estados Unidos Mexicanos"; Enrique Samano Salgado, "Segunda lectura el dictamen en que se consulta la aprobación del proyecto de decreto de Ley Reglamentaria del artículo 27 constitucional en materia de explotación y aprovechamiento de recursos minerales, ya aprobado por la Cámara de Senadores. Se discute en los general y se aprueba en ese sentido. En lo particular se discutieron los artículo 45 y 46 el C. diputado Enrique Salgado Sámano y en pro hablaron los CC. diputados José de Jesús Ortega Calderón y Rafael Espinosa Flores, respectivamente. Se aprueban los artículos impugnados y los no objetados. Pasa el proyecto al Ejecutivo Federal para efectos constitucionales," Diario de los Debates de la Cámara de Diputados del Congreso de los Estados Unidos Mexicanos. Año III, Legislatura XLIV, Periódo Ordinario, Tomo I, Número 42. December 29, 1960. México D.F. http://cronica.diputados.gob.mx (Accessed May 8, 2016). 37-38; "Se Considera Mortalmente Amenazada a la Minería," El Universal, December 20, 1960; Ing. Máximo Muñoz, "La Nueva Ley Minera," Excélsior, December 26, 1960; "De la Ley Minera, en las Audiencias, Sólo se Aplaude un Aspect: la Mexicanización," Excélsior, December 8, 1960; "Puntos de Vista Industriales Sobre Mexicanización Minera, " El Nacional, December 8, 1960; Editorial, "Críticas Negativas al Nuevo Proyecto de Ley Minera," El Popular, December 9, 1960.
} 
to reorganize the mining industry technically and economically" to increase production and produce national effects. ${ }^{89}$

Some lawmakers and professionals made overtures toward nationalization but quickly yielded to more moderate stances. Senator Natalio Vázquez Pallares, for instance, asserted that the only definitive solution to the country's problems would be the complete nationalization of the mining industry. ${ }^{90}$ Yet, he quickly pointed out his recognition of the need for prudence, and acknowledged that the nationalization of oil had occurred during a specific historical context that aided its success. Ernesto Lobato, chair of economics at the National Autonomous University of Mexico (UNAM), supported the law because it was simultaneously nationalist and pragmatic. He supported the gradual restructuring of the mining industry "through an evolution compatible with the necessities and possibilities of the country, within the framework of the historical reality that we are living." ${ }^{91}$ While not as direct or totalizing in scope, Mexicanization represented a significant step toward a future in which Mexico reclaimed "the

\footnotetext{
89 "Primera lectura a dos dictámenes sobre las iniciativas enviadas por el C. Presidente de la República para reformar la Ley Reformatoria del Artículo 27 Constitucional, en materia de explotación y aprovechamiento de recursos minerales, y de reforma al artículo 56 de la Ley de Impuesto y Fomento a la Minería," Diario de los Debates de la Cámara de Diputados del Congreso de los Estados Unidos Mexicanos. Año III, Legislatura XLIV, Periódo Ordinario, Tomo I, Número 41. December 28, 1960. México D.F. http://cronica.diputados.gob.mx (Accessed May 8, 2016), 37.

${ }^{90}$ Natalio Vázquez Pallares, "Ley Reglamentaria del Artículo 27 Constitucional en Materia de Exportación y Aprovechamiento de Recursos Minerales." Diario de los Debates de la Cámara de Senadores del Congreso de los Estados Unidos Mexicanos. Año III, Legislatura XLIV, Periodo Ordinario, Tomo III, Número 34. México, D.F.: December 22, 1960.

91 "Opiniones en pro y en Contra de la Ley Minera Escucháronse Ayer en el Senado," Excélsior, December 10, 1960.
} 
complete patrimony of the nation."92 Alfredo Valtierra, director of Mines and Oil, a sub-division of SEPANAL, described the policies of Mexicanization as a "healthy nationalism that does not intend to trample over acquired rights nor exclude foreign capital." 93

Supporters advanced numerous defenses of state intervention. Against critiques that the nationalist aspects of the law opposed liberal economic policies, supporters of intervention argued that all countries had adopted "forms of economic policy incompatible with classical liberalism" and saw in this philosophy the "right of the strong to extend its power freely, and a barrier for the weak who yearned to free themselves." ${ }^{94}$ Against arguments of the law's unconstitutionality, Senator Ramón Ruiz Vasconcelos argued that the Constitution provided for the exploitation of mineral resources by individuals and corporations, the latter of which included the possibility of entities created by the state. In addition to the mining enterprises themselves, the task of mineral exploitation would be facilitated through the creation or reorganization of the state's "own specialized organisms" such as the Mining Agencies, the Council of Non-Renewable Resources, and the Mining Development Commission. ${ }^{95}$

\footnotetext{
92 Natalio Vazques Pallares, "Ley Reglamentaria del Artículo 27," Diario de los Senadores, December 22, 1960, 45.

93 “El Capital Extranjero Sólo Como Auxiliar en la Minería," Excélsior, December 10, 1960.

${ }^{94}$ Editorial, "El Espíritu de la Ley Minera," El Universal, December 23, 1960.

95 "El Senado Aprobó en lo General, la Ley de Recursos Minerales," El Nacional, December 22, 1960; Ramón Ruiz Vasconcelos, "Sobre el Proyecto de Ley Orgánica," Diario de Senadores, 8; Secretaría de Gobernación, "Ley Reglamentaria del Artículo 27 Constitucional en materia de explotación y aprovechamiento de recursos minerales," Diario Oficial, February 6, 1961, 94-103.
} 
Against fears that Mexicanization would impose a mining state, Senator Manuel Moreno Sánchez argued that the Mexican people could not wait while the mining industry remained idle in the hands of foreign private investors who were unwilling to revive production and make new investments. ${ }^{96}$

To strengthen the legitimacy of Mexicanization, its proponents touted its connection to colonial mining policy. Senator Ramón Ruiz Vasconcelos argued that the mining project was "congruent with the historic tradition of our country" in which the subsoil's property is the inalienable patrimony of the sovereign with the state charged to develop it according to the general will. ${ }^{97}$ The transfer of sovereignty from the Spanish king to the Mexican nation kept these policies intact, but were disrupted when Porfirian mining laws broke this tradition. The laws of 1882, 1890, and 1909 were considered the most liberal mining laws in Mexican history: They ceded control of mineral resources to foreign investors, "repudiating. . . [the] patrimonial rights of the State over the subsoil sustaining, instead, that they were the exclusive property of the owner of the surface."98 Article 27 restored colonial mining policy but on behalf of the sovereign Mexican nation. If successful, Mexicanization would join other legislative milestones - the 1857 Constitution, 1917 Constitution, and the 1938 oil nationalization - as

\footnotetext{
96 Manuel Moreno Sánchez, "Sobre el Proyecto de Ley Orgánica," Diario de Senadores, 13; "EI Senado Aprobó en lo General, la Ley de Recursos Minerales," El Nacional, December 22, 1960.

${ }^{97}$ Ramón Ruiz Vasconcelos, “Sobre el Proyecto de Ley Orgánica," Diario de Senadores, 7.

98 "Continuaron las Audiencias Mineras," Excélsior, December 9, 1960.
} 
another step toward the consolidation of national sovereignty and begin a "new and transcendental stage in the history of our mining."99

Supporters of the Mexicanization law acknowledged that the state desired greater participation and control of the industry but emphasized repeatedly that it did not seek direct ownership or management. They conceded that the exploitation of mineral resources was too large and complex for the state to administer alone. They desired the participation of the private sector and conceived a relationship in which the private sector and the Mexican state worked in coordination. The government also desired the participation of foreign investment, as an essential component of Mexico's economic development. Ernesto Lobato claimed that the law was nationalist but "without ... prejudicing the rights previously acquired by foreigners."100 And, though it may have preserved too many rights of foreigners for some, the moderate policy of Mexicanization sought to preserve the connection to "global markets and the system of association," needed for the export of products manufactured domestically. ${ }^{101}$ Senator Agustín Olivo Monsiváis maintained that the state would respect the private sector but affirmed that it "will intervene in everything that is the work of superior coordination, future planning, and general inventory of

\footnotetext{
99 "Escucháronse Ayer en el Senado," Excélsior, December 10, 1960; Sariego et al., El estado, 361-362; Ramón Ruiz Vasconcelos, "Sobre el proyecto de la Nueva Ley," Diario de Senadores, December 13, 1960, 7-8; "Continuaron las Audiencias Mineras," Excélsior, December 9, 1960.

100 "Opiniones en pro y en Contra de la Ley Minera Escucháronse Ayer en el Senado," Excélsior, December 10, 1960; Wallace Hall, iii.

101 "La Cámara Minera Está en Favor de la Mexicanización de la Industria," Excélsior, December 10, 1960.
} 
resources, in short, in all those tasks that correspond to it because of its public nature and its historical responsibility." ${ }^{102}$

When Secretary Bustamente began campaigning for the law in September 1960, his main goal was to clarify the differences between Mexicanization and nationalization. He admitted that Mexicanization was similar to the oil nationalization since it entailed state intervention in the economy. But in contrast to nationalization, Mexicanization would not involve a takeover of mining properties nor create a centralized state-owned and operated enterprise like Petroleos Mexicanos (PEMEX) to administer them. To pacify fears of nationalization, Bustamente claimed that such a maneuver was impossible because the nation's mines had always been the property of the Mexican nation. The purpose of state intervention, then, was to rescue the industry from its decades-long stagnation, and ultimately, to transfer mining property to private Mexican owners. ${ }^{103}$

\footnotetext{
${ }^{102}$ Agustín Olivo Monsiváis, Mexican Senate, "Lectura," Diario de Senadores, December 1, 1960, 6; Ramón Ruiz Vasconcelos, "Sobre el proyecto de la Nueva Ley," Diario de Senadores, 7-8; "Continuaron las Audiencias Mineras," Excélsior, December 9, 1960; "85 por Ciento de la Minería Nacional es de Extranjeros, Dice Patrimonio," Excélsior, December 9, 1960; Comisiones Unidas de Estudios Legislativos, Segunda de Minas, y de Bienes y Recursos Nacionales, "Sobre el proyecto de la Nueva Ley," Diario de Senadores, 6.

${ }^{103}$ Editorial, "Mexicanización de la Minería," Excélsior, September 30, 1960; Ing. Máximo Muñoz, "La Nueva Ley Minera," Excélsior, December 26, 1960; Editorial, "Mexicanización de la Minería," Excélsior, December 15, 1960; "Lo que se Hará en el Caso de Nuestro Minería," El Nacional, October 1, 1960; Julian Carlos y Jiménez, "Los Minerales de México Dejarán de ser Sólo Reservas de Extranjeros," Excélsior, October 1, 1960; Editorial, "Una Nueva Ley Minera," El Popular, October 3, 1960. José Manuel Jurado, "Prepárese una ley que Permitirá Mexicanizar Nuestra Minería," Excélsior, September 29, 1960. Editorial, "Mexicanización de la Minería," Excélsior, December 15, 1960.
} 
After hearing these and other arguments, the United Commissions revised the draft accordingly. The bulwark of support came from government agencies and state-affiliated organizations such as the national mining union. Opposition came primarily from professional and business interest groups such as the Association of Mining Engineers, Metalworkers, and Geologists, the Mexican Mining Chamber, and the Mining and Commercial Credit company. ${ }^{104}$ The bill drafted by the SEPANAL eventually led to the Mexicanization of Mining Law (Ley Reglamentaria de Artículo 27 Constitucional en materia de

${ }^{104}$ Armando Fischer S. "Nueva Ley que Apoya la Minería y la Metalurgía," Novedades September 19, 1960. Mexican Senate, "Lectura," Diario de Senadores, December 1, 1960, 3-5; Points I, II, III, IV, VI, VII, VIIIX, XI, XII, XIII, XIV; "Primer Paso Para que la Riqueza Minera del País Pertanezca del Todo a México," Excélsior, December 2, 1960; Mexican Senate, "Lectura," Diario de Senadores, December 1, 1960, 3; Enrique Dupré Ceniceros, Alfredo de Lara Isaacs, Mauricio Magadaleno Cardona y Agustín Olivo Monsiváis; "Sobre el proyecto de la nueva Ley de Minas," Diario de los Debates de la Cámara de Senadores del Congreso de los Estados Unidos Mexicanos, Año III, Legislatura XLIV, Periodo Ordinario, Tomo III, Número 28. México, D.F.: December 13, 1960, http://infosen.senado.gob.mx/documentos/DIARIOS/1960_08_221960_12_30/1960_12_13_O.pdf (Accessed May 8, 2016), 5.

Director of Economic Studies of SHCP: Rafael Urrutía Millán

Sec. Industria y Comercio: sub-secretary Plácido García Reynoso

Departamento de Investigaciones Industriales del Banco de Mexico: Emilio Alanis Patiño

Sub-Secretary of Non-Renewable Resources: Salvador Peña

Minas y Petroleos, subgroup of SEPANAL: Alfredo Baltierra

Gerente del Consejo de Recursos Naturales no Renovables: Salvador Cortés Obregón

President of Comisión de Fomento Minero: Oswaldo Gurría Urgel

President of Comisión Nacional de Energía Nuclear José María Ortiz Tirado

Interest and Trade groups

Asociación de Ingenieros Mineros, Metalúrgicos y Geólogos: Luis Villaseñor, Enrique Casas

Alatriste, C.P.T, José E. Villalobos Ruíz.

Federación Nacional de Asociaciones de Mineros en Pequeño: Enrique Casas Alatriste

El Crédito Minero y Mercantil S.A.: Jose A. Garcia, Luis Latapi

La Cámara Minera: José Campillo Saenz, Gustavo P. Serrano

Ernesto Lobato López: Economics chair at UNAM)

National Mining Union: Napoleó Gómez Sada

Representative of various individual miners:: Eduardo López Prieto

Mexican Senate, "Sobre el proyecto de la Nueva Ley," Diario de Senadores, December 13, 1960, 6. 
explotación y aprovechamiento de recursos minerales, or Ley de Mexicanización de Minería). At its broadest, the law was intended to normalize "the principle of national sovereignty over mineral resources and their exploitation consecrated in the constitutional article 27."105 It focused on six main problems: the creation of government organizations inside the mining industry, the performance of fiscal policy, the structure of parastate companies, the regulation and arbitration of labor, and the management of working conditions. ${ }^{106}$

While tackling such problems, Mexicanization pursued three long-term objectives. First, the movement of the mining industry away from the foreigndominated, export-oriented model of production. Second, the integration of the industry toward domestic needs and the process of national industrialization. Third, the promotion of the domestic processing of raw mineral resources. In so doing, it sought to stimulate new industries, increase diversification, improve the nation's technical capacity, add new sources of employment, and provide cheap inputs for national industries. ${ }^{107}$

Mexicanization proposed to achieve these objectives by increasing state intervention. The main tactic involved the restructuring of mining property by transforming the concessionary regime so that concessions could only be

\footnotetext{
105 Sariego, Enclaves, 291.

106 Sariego et al., El estado, 13.

107 "Se Orientará la Producción Minera Hacia la Satisfacción de las Demandas del País: Exposición de las Bases de la Nueva Ley," El Nacional, September 29, 1960; "Con su Nueva Legislación se Dará un Sentido Mexicanista a la Minería," El Nacional, December 28, 1960; Manuel Moreno Sanchez, "Sobre el Proyecto de Ley Orgánica," Diario de Senadores, 11.
} 
granted to those enterprises with a majority of Mexican ownership. This requirement permitted the inclusion of both the state and the private sector into the mining industry while preserving foreign investment. ${ }^{108}$

The streamlining of bureaucratic procedure occurred through the aforementioned creation of the Secretary of National Patrimony. As granted in the Law of Secretaries and Departments of the State of 1958 and then in the Mexicanization Law of 1961, SEPANAL made the final decisions on the rights and obligations of concession holders; possessed the right to intervene in the organization, direction, administration, and finances of parastate enterprises; and, oversaw subordinate dependencies tasked with the day-to-day execution of the law. ${ }^{109}$

President López Mateos signed the law on February 5, 1961. The new law imposed several nationalist requirements that pertained to the Mexicanization of the Compañía Minera de Cananea. The fourteenth article of the law stated, "Only Mexicans and corporations constituted in agreement with Mexican laws and that have the majority of capital underwritten by Mexicans, have the right to obtain the concessions." ${ }^{110}$ This requirement comprised the key

108 Sariego et al., El estado 35, 248; Moreno Sánchez, "Sobre el Proyecto de Ley Orgánica," Diario de Senadores, 10; Sariego, Enclaves, 287-288, 292-293, 295.

109 Secretaría de Gobernación, "Ley Reglamentaria del Artículo 27 Constitucional en materia de explotación y aprovechamiento de recursos minerales," Diario Oficial, Tomo, CCXLIV, núm 31, February 6, 1961, 5, 12, 14.

110 Secretaría de Gobernación. "Ley Reglamentaria del Artículo 27 Constitucional en materia de explotación y aprovechamiento de recursos minerales," Diario Oficial, February 6, 1961, article 14; Mexican Senate, "Lectura," Diario de Senadores, December 1, 1960, article 9, p. 7. 
innovation and mechanism of Mexicanization. Significantly, this did not comprise a nationalization of the industry. While increasing the possibility of state intervention, the law also permitted the inclusion of private enterprise and preserved foreign participation in the mining industry while reducing its control. ${ }^{111}$ As a result, new types of mining enterprises with various combinations of the state, national and foreign investors became possible. ${ }^{112}$

For existing mining companies with foreign ownership, like the Compañía Minera de Cananea, the law contained no schedule or requirement for compliance with it, permitting companies to act at their own discretion. Stronger efforts to restructure property were out of the question: the restrictions to be imposed by Mexicanization were considered so demanding that incentives and security for investments were needed to encourage compliance. Domestic investors needed them because Mexicanization dissuaded the participation of foreign capital in the mining industry. Foreign investors also benefited from this arrangement because incentives, rather than retroactive measures, became the primary means of achieving Mexicanization. Incentives were not included in the Mexicanization Law but in amendments to the 1955 Law on Mining Taxes and Development. Articles 52 and 56 provided a series of graduated tax exemptions

\footnotetext{
111 "Mexicanizar las Minas: Firme Tesis del Senado" Excélsior, December 14, 1960; Secretaría del Patrimonio Nacional, "Reglamento de la Ley Reglamentaría del Artículo 27 Constitucional en Materia de Explotación y Aprovechamiento de Recursos Minerales," (February 28, 1961), article 250.

112 Secretaría de Gobernación. "Ley Reglamentaria del Artículo 27 Constitucional en materia de explotación y aprovechamiento de recursos minerales," Diario Oficial, February 6, 1961, article 2; Mexican Senate, "Lectura," Diario de Senadores, December 1, 1960, articles 1, 4, 5, p. 7.
} 
to new mining operations or mining operations that had been defunct for more than ten years. The reforms in December 1960 extended these incentives to those companies which complied with the capital structure requirement in the Mexicanization Law. ${ }^{113}$

In contrast to the decades-long emphasis on fiscal policy, Mexicanization did emphasize more direct forms of state intervention. In order to fulfill the social and economic aspirations of the 1917 Constitution, supporters of the law wanted to confirm the dominion of the nation over its mineral wealth and use the state "to protect, support, and develop that wealth."114 State intervention would benefit the Mexican nation through industrialization and employment, strengthen industry, secure economic independence, and consolidate national sovereignty. ${ }^{115}$ The ultimate argument for state intervention rested upon the claim that its final goal was the transfer of "mining property and mining concessions into the hands of private Mexican companies."116 After its

\footnotetext{
${ }^{113}$ Wallace Hall, La dinámica del sector minero, 140; "De la Ley Minera, en las Audiencias, Sólo se Aplaude un Aspecto: la Mexicanización," Excélsior, December 8, 1960; "La Ley que Estudia el Senado Solo Destruría la Minera Mexicana," Excélsior, December 8, 1960; Gustavo P. Serrano, "Puntos de Vista Industriales Sobre Mexicanización Minera," El Nacional, December 8, 1960; "La Cámara Minera Está en Favor de la Mexicanización de la Industria," Excélsior, December 10, 1960; Enrique Sámano Salgado, "Segunda lectura," Diario de los Diputados, 37-38; "Primera lectura," Diario de los Diputados, 37-38.

${ }^{114}$ Editorial, “El Debate Sobre la Nueva Ley Minera," El Popular, December 14, 1960.

115 Editorial, "Una Minería Mexicana," Novedades, December 14, 1960; Teodoro Hernández, "El Proyecto de Ley Minera Responde a una Necesidad Nacional," December 18, 1960; "La Nueva Ley Minera Lesiona Intereses de Quienes Progresaron con la Anterior," Novedades, December 28, 1960; "Con su Nueva Legislación se Dará un Sentido Mexicanista a la Minería," El Nacional, December 28, 1960; Sariego et al., El estado, 14; Manuel Moreno Sanchez, "Sobre el Proyecto de Ley Orgánica," Diario de Senadores, 12-13.
}

${ }^{116}$ Editorial, "Mexicanización de la Minería," Excélsior, September 30, 1960; Ing. Máximo Muñoz, "La Nueva Ley Minera," Excélsior, December 26, 1960; Editorial, "Mexicanización de la Minería," 
Mexicanization in 1971, the Compañía Minera de Cananea became a parastate enterprise - a corporation with state, domestic, and foreign participation - when Anaconda sold $51 \%$ of its shares to a combination of public and private investors in Mexico. ${ }^{117}$

\section{Conclusion}

Beginning in 1961, the Mexicanization of the mining industry emerged as the strongest assertion of national sovereignty over the nation's mineral resources. Yet, in contrast to the nationalization of the oil sector in 1938, Mexicanization represented a more moderate and conservative approach. Instead of taking complete ownership and administration of the mines by the state, the primary goal of state intervention became the transfer of mining property to the domestic private sector. This change in policy largely resulted from the conservative reaction that followed the oil nationalization and was thus designed primarily to appeal to pro-business factions. Since 1938, however,

\footnotetext{
Excélsior, December 15, 1960; "Lo que se Hará en el Caso de Nuestro Minería," El Nacional, October 1, 1960; Julian Carlos y Jiménez, "Los Minerales de México Dejarán de ser Sólo Reservas de Extranjeros," Excélsior, October 1, 1960; Editorial, "Una Nueva Ley Minera," El Popular, October 3, 1960; José Manuel Jurado, "Prepárese una ley que Permitirá Mexicanizar Nuestra Minería," Excélsior, September 29, 1960; Editorial, "EI Debate Sobre la Nueva Ley Minera," El Popular, December 14, 1960; Editorial, "Mexicanización de la Minería," Excélsior, December 15, 1960; Sariego et al., El estado, 35, 69, 248, 252; Gerardo Corneja Murrieta, Ed. Historia General de Sonora V: Historia Contemporánea de Sonora, 1929-1984. Vol. 3. (Hermosillo: Gobierno del Estado de Sonora, 1985), 239.

117 Secretaría de Gobernación. "Ley Reglamentaria del Artículo 27 Constitucional en materia de explotación y aprovechamiento de recursos minerales," Diario Oficial, February 6, 1961, article 5; Secretaría del Patrimonio Nacional, "Reglamento de la Ley Reglamentaría del Artículo 27 Constitucional en Materia de Explotación y Aprovechamiento de Recursos Minerales," Diario Oficial, February 28, 1962, article 250.
} 
state intervention had created such a strong association with nationalization that the proponents of Mexicanization remained always on the defensive during the debates on the law in late 1960. Editorials and debates revealed that the two nationalist processes were often considered equivalent, and the burden to distinguish them rested on government officials. Thus, the debates on Mexicanization and their substantive innovations, the capital majority requirement, reveal an actual change directed toward elite concerns. How these changes were negotiated with respect to popular concerns of national sovereignty is the subject of the next chapter. 


\section{CHAPTER III \\ The Mexicanization of Compañía Minera de Cananea, 1971}

A decade after the passage of the Mexicanization Law in 1961, the Compañía Minera de Cananea $(\mathrm{CMC})$ became the final large mining enterprise to undergo the process. This concluded a long struggle that began in 1906, sustained itself over generations, and culminated in President Luis Echeverría's announcement on August 27, 1971. The Mexicanization of the CMC completed Mexico's strongest effort to assert national sovereignty over its mineral resources. Ostensibly, it represented the peak of nationalism in the mineral industry and the recovery of the nation's mineral resources. To be sure, scholars have regarded the nationalization of the oil industry as the apotheosis of the Mexican Revolution and the consummation of revolutionary nationalism. ${ }^{1}$ In contrast, the Mexicanization of mining revealed a conception of national sovereignty representative of the institutionalized Mexican Revolution and a "corrupted" form of revolutionary nationalism that emerged with President Miguel Alemán.

As a result, the approach taken to mining represented the victory of elites over the revolution. While the Mexican Revolution initiated genuine change in Mexico, it obscured the continuation of pre-revolutionary tendencies such as authoritarianism, marginalization, oppression, and the perpetuation of elite rule. Adam Morton has aptly described the Mexican Revolution as a passive

\footnotetext{
1 "Alan Knight, "Introduction," in The Mexican Petroleum Industry in the Twentieth Century," eds. Jonathan C. Brown and Alan Knight (Austin: University of Texas, 1992), xv.
} 
revolution, arguing that "both state intervention and mass mobilization were conjoined to ensure processes of primitive accumulation and the creation of modern capitalism." ${ }^{2}$ Mass mobilization legitimized limited social change, but its more enduring effects brought change in favor of a new elite, in which new power was consolidated, the progressive aspects of the revolution eroded, and class rule restored. ${ }^{3}$

As discussed in the previous chapter, the legislative phase of Mexicanization confronted the discourse established by the nationalization of the oil industry under Cárdenas. His action had established a narrative in which state intervention became associated with the complete takeover and management of strategic natural resources by the state, foreclosing the participation of the private sector and foreign investors. The social myth of revolutionary nationalism defined legitimate power strictly within the context of the nation-state, and empowered the state to act on behalf of the nation and serve as an intermediary for labor. With Mexicanization, government officials offered a counter discourse for elite consumption, promoting the idea that state intervention and the national control of resources would serve private interests. The restoration of class rule is particularly significant in the post-Cardenista period, during which the ideals of the Mexican Revolution increasingly diverged from its reality. The Mexicanization of the Compañía Minera de Cananea, three

\footnotetext{
${ }^{2}$ Adam D. Morton, Revolution and State in Modern Mexico: The Political Economy of Uneven Development (Lanham, MD: Rowman and Littlefield Publishers, 2011), 24-25.

${ }^{3}$ Morton, Revolution and State, 4, 38.
} 
decades after the end of Cardenas's presidency (1934-1940), resides at the edge of revolution and reaction.

The Mexicanization of the CMC emerged as one of the last gasps of the Mexican Revolution and revolutionary nationalism in the second half of the twentieth century. Still, it was at the same time a byproduct of conservative efforts to assuage foreign capital, whose vociferous reaction after the oil nationalization had generated multiple crises in the country. As Mexican politics became less revolutionary and more conservative, the ideology of revolutionary nationalism remained an essential basis for the legitimacy of the Mexican state and the governing party. But, increasingly, it served the narrower interests of the elite and offered fewer direct benefits for workers. Despite the differences between nationalization and Mexicanization, government officials maintained the rhetoric of revolutionary nationalism while advancing a more moderate policy to assert "sovereign" control of mineral resources. Nonetheless, the Mexicanization of Compañía Minera de Cananea was promoted as both a total assertion of national sovereignty, equivalent to nationalization, and a fulfillment of the Mexican Revolution.

This chapter demonstrates how the Mexicanization of the Compañía Minera de Cananea appealed to notions of popular national sovereignty. While Mexicanization had to appeal to elites, it also had to appeal to ordinary Mexicans, particularly workers. So, it preserved the popular discourse established by Cárdenas: that the achievement of national sovereignty and control of natural resources would be used to advance the social well-being of the Mexican people; 
that the Mexican state embodied the general interest of the nation; and, that workers were to play a role subordinate to national interests. The critical change from nationalization to Mexicanization, mentioned in the previous chapter, involved the latter's opening to the participation of foreign investors in the mining industry. This inclusion threatened the legitimacy of Mexicanization as a true nationalist policy. As a result, government officials worked to demonstrate that national sovereignty would be strengthened by foreign participation rather than weakened by it. In the end, Mexicanization demonstrated the achievement of a distinctly national sovereignty that subordinated the working class to the Mexican nation's needs.

This chapter focuses on the Mexicanization of the Compañía Minera de Cananea in 1971. Much of its organization and many of its themes parallel those encountered in the previous chapter. With respect to the nationalization of the oil industry, this chapter focuses less on its political, economic, and geopolitical aspects and examines more closely the relationship between the Mexican nation and the oil workers. Where the previous chapter focused on the legislative aspects of Mexicanization, this chapter examines its implementation from 1961 to 1971, concluding with the Mexicanization of the Compañía Minera de Cananea.

\section{Article 27: Social Function of Property}

The previous chapter, examined the concession theory of property in article 27, this section considers its social function. Article 27 of the 1917 Constitution presents national patrimony as a form of property distinct from 
modern conceptions of private property. In western legal tradition, private property emerged as a natural inalienable right of the individual. Martín Díaz y Díaz criticized this absolute notion of property for "rarely recognizing that its dispositions may be in tension with the social dynamic." He rejected the ideas of "private property. . . as a unique institution and [that] its consolidation implies the elimination of original patrimonial rights," that is other possible competing quasiproperty rights. ${ }^{4}$ In contrast, article 27 proffered a different type of property. Compared to its western version, private property in Mexico, in particular that over the subsoil, did not emanate from natural right, nor was it sacred or absolute; instead, it was granted by concession and never released from the state's sovereign ownership. ${ }^{5}$ Thus, private property could be regulated, appropriated, and redistributed or conserved according to national and public need. ${ }^{6}$

\section{Nationalization of the Oil Industry: Cultural Facets}

Where the previous chapter focused on the legal, political, and economic, aspects of the oil nationalization, this chapter examines the foundational cultural discourses related to national sovereignty in Mexico. These discourses communicate the nature of relationships among the various factors of production

\footnotetext{
${ }^{4}$ Martín Díaz y Díaz, "El Régimen Jurídico Ambiental del Subsuelo en México," in PEMEX: Ambiente y Energía: Los retos del futuro (México: Instituto de Investigaciones Jurídicas, Universidad Nacional Autónoma de México, Petróleos Mexicanos, 1995), 35.

${ }^{5}$ Díaz y Díaz, “El Régimen Jurídico...”, 37-38, 41; Francisco Arellano Rendón, El subsuelo mexicano: patrimonio nacional (México: [s.n.], 1970), 47-48.

${ }^{6}$ Arellano Rendón, El subsuelo mexicano, 20, 59. Díaz y Díaz, 38, 41.
} 
- labor, natural resources, and the organization of society. First, nationalization, defined by state administration of resources and the exclusion of foreign participation, became the means to achieve national sovereignty after centuries of foreign domination. Second, state control and management of natural resources became associated with economic and social development for the Mexican people. Third, the Mexican state embodied the general interest of the Mexican nation. Fourth and last, workers were to inhabit a passive role in Mexican society, subordinate to the Mexican nation and state.

When President Cárdenas announced the nationalization of oil deposits on March 18, 1938, he was met with broad popular enthusiasm including the support of industrialists, labor, and the middle class. Spontaneous popular mobilizations in support of the government's actions occurred on March 22 and 23. Private citizens and neighborhoods collected funds to finance the costs of the nationalization, leading to the creation of the Mexican Committee for Economic Liberation (CUMPLE) to administer the funds. Though meager in proportion to the total cost of compensation, the symbolic weight of this gesture was substantial as ordinary, working Mexicans paid the debt of nationalization to express their patriotic support against decades of foreign control. ${ }^{7}$

\footnotetext{
${ }^{7}$ Díaz y Díaz, 37-38, 41; Arellano Rendón, El subsuelo mexicano, 47-48; Hector Aguilar Camín, and Lorenzo Meyer, In the Shadow of the Mexican Revolution: Contemporary Mexican History, 1910-1989, trans. Luis Alberto Fierro (Austin: University of Texas Press, 1993), 154; Manuel Martínez Sicilia, "Contestación del Dip. Manuel Martínez Sicilia, Presidente del Congreso," Informe del Presidente Lázaro Cárdenas, September 1, 1940 (http://www.biblioteca.tv/artman2/uploads/1940.pdf), 141; Lázaro Cárdenas, "El Gral. Lázaro Cárdenas, al abrir el Congreso sus sesiones ordinarias, el $1^{\circ}$ de septiembre de 1938," Informe del Presidente Lázaro Cárdenas, September 1, 1938 (http://www.biblioteca.tv/artman2/uploads/1938.pdf), 88.
} 
During the revolution, a pragmatic desire by revolutionaries to control the oil industry became incorporated into the program of revolutionary economic nationalism and consecrated in the 1917 Constitution. A pragmatic decision with a lasting cultural influence, revolutionary nationalism helped to unite warring factions of Mexicans against a common enemy - foreign investors who dominated the nation's economic interests. And nationalization, legitimized in article 27 , became the most effective means to exercise national sovereignty against the continued dominance of foreign interests and end the neo-colonial structure of foreign ownership and export-orientation of a strategic industry. This represented the height of the nationalist revolution. ${ }^{8}$ This concluded the struggle of the Mexican people to affirm the national patrimony of oil resources and further "solidify the sovereignty of the Nation on solid bases that guarantee its effective independence." 9

The achievement of economic independence promised popular social benefits. Deputy Manuel Gudiño believed that the greatest triumph of

\footnotetext{
${ }^{8}$ Lorenzo Meyer, Mexico and the United States in the Oil Controversy, 1916-1942 (Austin: University of Texas Press, 1977), xii-xiii, 170, 173, 229-230; César Martino, "Contestación del Dip. César Martino, Presidente del Congreso," Informe del Presidente Lázaro Cárdenas, September 1, 1939 (http://www.biblioteca.tv/artman2/uploads/1939.pdf), 116; Lázaro Cárdenas, "El Gral. Lázaro Cárdenas, al abrir el Congreso sus sesiones ordinarias, el $1^{\circ}$ de septiembre de 1938," Informe del Presidente Lázaro Cárdenas, September 1, 1938.

(http://www.biblioteca.tv/artman2/uploads/1938.pdf), 89; Manuel Martínez Sicilia, "Contestación del Dip. Manuel Martínez Sicilia, Presidente del Congreso," Informe del Presidente Lázaro Cárdenas, September 1, 1940 (http://www.biblioteca.tv/artman2/uploads/1940.pdf), 138; Manuel Gudiño, "Contestación del Dip. Manuel Gudiño, Presidente del Congreso," Informe del Presidente Manuel Avila Camacho, September 1, 1942 (http://www.biblioteca.tv/artman2/uploads/1942.pdf), 239.

${ }^{9}$ Lázaro Cárdenas, "El Gral. Lázaro Cárdenas, al abrir el Congreso sus sesiones ordinarias, el $1^{\circ}$ de septiembre de 1938," Informe del Presidente Lázaro Cárdenas, September 1, 1938 (http://www.biblioteca.tv/artman2/uploads/1938.pdf), 82.
} 
nationalization was the achievement of the "economic and moral salvation of the Mexican people."10 He regarded the exercise of national sovereignty as the foundation for economic independence, which in turn provided the basis for political liberty: "Without economic liberty, political liberty will always end up being a hollow term." ${ }^{11}$ Nationalization implied not only better wages but also better treatment for workers and their elevation in the eyes of Mexican society. The social implications of nationalization also constituted a more humanistic regard for workers as indispensable and deserving of "the protection of life, health and the material and moral patrimony." ${ }^{12}$ Improved facilities and stronger rights to "educational services, doctors, and social welfare" were direct improvements for oil workers, which provided indirect positive effects for the well-being of the economy and allowed workers "to lend an effective service to the collectivity and increase. . the patrimony of the nation."13

\footnotetext{
${ }^{10}$ Rodolfo Delgado, "Contestación del Dip. Rodolfo Delgado, Presidente del Congreso," Informe del Presidente Lázaro Cárdenas, September 1, 1938 (http://www.biblioteca.tv/artman2/uploads/1938.pdf), 100; Manuel Gudiño, "Contestación del Dip. Manuel Gudiño, Presidente del Congreso," Informe del Presidente Manuel Avila Camacho, September 1, 1942 (http://www.biblioteca.tv/artman2/uploads/1942.pdf), 239.

11 Manuel Gudiño, "Contestación del Dip. Manuel Gudiño, Presidente del Congreso," Informe del Presidente Manuel Avila Camacho, September 1, 1942 (http://www.biblioteca.tv/artman2/uploads/1942.pdf), 236.

12 Manuel Avila Camacho, "El Gral. Manuel Avila Camacho, al abrir el Congreso sus sesiones ordinarias, el $1^{\circ}$ de septiembre de 1941," Informe del Presidente Manuel Avila Camacho, September 1, 1941 (http://www.biblioteca.tv/artman2/uploads/1941.pdf), 173.

${ }^{13}$ Manuel Avila Camacho, "El Gral. Manuel Avila Camacho, al abrir el Congreso sus sesiones ordinarias, el $1^{\circ}$ de septiembre de 1941," Informe del Presidente Manuel Avila Camacho. September 1, 1941 (http://www.biblioteca.tv/artman2/uploads/1941.pdf), 172.
} 
With national control of natural resources, economic development would shift away from exclusive market-centered policies, proceeding according to national needs rather than foreign ones. After centuries of unrestrained exploitation, lawmakers desired rational control over resource production. Rational control, they argued, would make production more efficient while granting more consideration to social purposes. Together, some of those lawmakers considered the economic and social orientation of production as measures in defense of national patrimony. Beyond the sphere of petroleum, Cárdenas called more generally for moderation in the pursuit of profits, and toward the creation of an economy that benefited the majority rather than the interests of a few. In his 1942 presidential address, Avila Camacho exclaimed that Mexico followed a unique and alternative path to national development, one that demanded "a humanization of the systems of commerce and...an effective recognition of the rights of each nation" by which "sovereignty may be respected." ${ }^{14}$ Social and economic goals converged in PEMEX. Direct material outcomes included the provision of lower-grade gasoline at lower prices to domestic consumers, the subsidization of fuel prices for transportation infrastructure needs, and "a level of employment that took account of social and political needs in addition to efficient production standards." ${ }^{15}$

\footnotetext{
${ }^{14}$ Manuel Avila Camacho, "El Gral. Manuel Avila Camacho, al abrir el Congreso sus sesiones ordinarias, el $1^{\circ}$ de septiembre de 1942," Informe del Presidente Manuel Avila Camacho, September 1, 1942 (http://www.biblioteca.tv/artman2/uploads/1942.pdf), 235.

${ }^{15}$ Clayton R. Koppes. "The Good Neighbor Policy and the Nationalization of Mexican Oil: A Reinterpretation," Journal of American History 69, no. 1 (Jun., 1982): 66-67; César Martino, "Contestación del Dip. César Martino, Presidente del Congreso," Informe del Presidente Lázaro
} 
Because of President Lázaro Cárdenas, the Mexican state came to embody the general interest or will of the Mexican people. The nationalization of the oil industry solidified the place of Lázaro Cárdenas as one of the most revered presidents in Mexican history, remembered alongside the revolutionary heroes Pancho Villa and Emiliano Zapata. He instituted changes related to "land, labor, the ruling party... popular measures [which] formed the cornerstone of his presidency and integrated campesinos, workers, and intellectuals into the revolutionary state."16 Through these measures, Cárdenas succeeded in consolidating the state and providing the foundation for future economic success. In the process, he remarked, "the state alone embodies the general interest, and for this reason the state has a vision of the whole. The state must continually broaden, increase, and deepen interventions."17

As a byproduct of nationalization, the Mexican state became the exclusive authority in the country, and ultimately, reduced the participatory role of labor. Some workers believed that nationalization would lead to their direct participation in the management of the industry's everyday operations. In August 1937, a workers' commission proposed the takeover and transformation of the Poza Rica

Cárdenas, September 1, 1939 (http://www.biblioteca.tv/artman2/uploads/1939.pdf), 141; Lázaro Cárdenas, "El Gral. Lázaro Cárdenas, al abrir el Congreso sus sesiones ordinarias, el $1^{\circ}$ de septiembre de 1939," Informe del Presidente Lázaro Cárdenas, September 1, 1939 (http://www.biblioteca.tv/artman2/uploads/1939.pdf), 101.

${ }^{16}$ Gilbert M. Joseph and Jürgen Buchenau, Mexico's Once and Future Revolution: Social Upheaval and the Challenge of Rule since the Late Nineteenth Century (Durham: Duke University Press, 2013), 126-127, 131; Meyer, Mexico and the United States, 151.

17 James M. Cypher, State and Capital in Mexico: Development Policy Since 1940 (Boulder, Colo.: Westview Press, 1990), 10-11. 
oil fields into a cooperative managed by workers. This "represented the first attempt by workers to modify the existing structure and property relations of the industry," but it was rejected by Cárdenas. ${ }^{18}$ It would have given workers complete control of production. Workers began taking steps in this direction in early 1938, prompting Cárdenas to move forward with nationalization. "Workers exercised de facto control of the mines," replacing managers and controlling production until July when Cárdenas eventually decreed the creation of Petroleos Mexicanos and the Distribuidora de Petroleos Mexicanos, thus professionalizing and centralizing the industry. ${ }^{19}$ Cárdenas also granted a local and limited role in administration to the national mining union, a "minority membership on the board of directors, ${ }^{20}$ as a means to appease labor and foster cooperation between unions, workers, and the state, without inhibiting "state administration at a national level."21

The Mexican state, however, did not merely seek labor's cooperation as an equal partner but sought to impose its dominance over the working class.

\footnotetext{
${ }^{18}$ Ruth Adler, "Worker Participation in the Administration of the Petroleum Industry, 1938-1940," in The Mexican Petroleum Industry in the Twentieth Century, eds. Jonathan C. Brown and Alan Knight (Austin: University of Texas, 1992), 131.

${ }^{19}$ Jonathan C. Brown, "Acting for Themselves: Workers and the Mexican Oil Nationalization," in Workers' Control in Latin America, 1930-1979, ed. Jonathan C. Brown (Chapel Hill: University of North Carolina Press, 1997), 45-46.

${ }^{20}$ Brown, "Acting for Themselves," 67.

${ }^{21}$ Adler, "Worker Participation," 129-132-133, 148; Brown, "Acting for Themselves," 45-46; Meyer, Mexico and the United States, 178; Secretaria de Hacienda y Crédito Público, "Decreto que crea la institución "Petróleos Mexicanos," Diario Oficial, July 20, 1938, 2-3; Secretaria de Hacienda y Crédito Público, "Decreto que crea la institución "Distribuidora de Petróleos Mexicanos," Diario Oficial, July 20, 1938, 3-4.
} 
After the nationalization, the leaders of the oil workers union demanded the wages and benefits increases that had been awarded in December 1937, an impossible demand in the context of an ongoing economic crisis and boycott, creating a tense relationship between workers and government officials. Eventually, the government imposed itself against the intransigent workers until they "had to conform to the imperatives of national policy."22 Appeals to the working class constituted an essential component of state legitimacy. At the same time, the state demanded labor's subservience to the needs of the nation. Except for the addition of 10,000 jobs, the "oil workers. . . gained little from the nationalization. . Wages rose and the work week fell from 44 to 40 hours, but management refused to grant the rest of the original labor award."23 The nationalization of oil thus recovered the industry from foreign companies while preempting its control by Mexican workers. A critical step in the consolidation of the Mexican state, nationalization defined the parameters of legitimate workers' actions within the context of state interests. ${ }^{24}$

Through nationalization, the Mexican state subordinated the interests of oil workers to those of the nation. After a change in its strategy, union leadership served less as an advocate for workers and more as one for private capital and

\footnotetext{
${ }^{22}$ Alan Knight, "Introduction," in The Mexican Petroleum Industry in the Twentieth Century, eds. John Brown and Alan Knight (Austin: University of Texas Press), xiii.

${ }^{23}$ Noel Maurer, "The Empire Struck Back: Sanctions and Compensation in the Mexican Oil Expropriation of 1938," Journal of Economic History 71, no. 3 (September 2011): 61.

${ }^{24}$ Meyer, Mexico and the United States, 178-179; Maurer, "Empire Struck Back," 612.
} 
the Mexican state, by discouraging independent labor activities and keeping wages low for domestic industry. These union leaders, under pressure by the government to reduce costs, neglected workers' aspirations to controlling industrial relations, and reformed union policy in 1939, seeking a collective contract that defined conditions and protected wages under the aegis of the state. While oil workers were elevated in the public eye, they were also encouraged to surrender their interests to those of the nation, "as guardians and custodians of this great national patrimony, conscious as they are of the responsibility they have acquired." 25 To the workers, the replacement of foreign control by Mexican control signified their increased power over work processes, conditions, and security. But for Cárdenas, sovereign control of mineral resources rested in the Mexican nation - to the exclusion of workers. ${ }^{26}$

The nationalist reforms implemented by President Cárdenas were critical to achieving economic independence and national sovereignty. From the economic foundation of the nation's oil industry, Deputy Rodolfo Delgado claimed that Mexico would construct "a new system of economic production" based on the ideals of the Mexican Revolution and revolutionary nationalism. ${ }^{27}$ Within this

\footnotetext{
${ }^{25}$ Adolfo Ruiz Cortines, "El Sr. Adolfo Ruiz Cortines, al abrir el Congreso sus sesiones ordinarias, el $1^{\circ}$ de septiembre de 1957," Informe del Presidente Adolfo Ruiz Cortines. September 1, 1957 (http://www.biblioteca.tv/artman2/uploads/1957.pdf), 647.

${ }^{26}$ Joseph and Buchenau, Mexico's Once and Future Revolution, 118, 143, 148-149; John Sherman, The Mexican Right: The End of Revolutionary Reform (Westport, Conn.: Praeger, 1997), 128; Brown, "Acting for Themselves," 67.

${ }^{27}$ Rodolfo Delgado, “Contestación del Dip. Rodolfo Delgado, Presidente del Congreso," Informe del Presidente Lázaro Cárdenas, September 1, 1938 (http://www.biblioteca.tv/artman2/uploads/1938.pdf), 100.
} 
system, Mexican workers labored on behalf of the Mexican nation, rather than for themselves. Ongoing labor problems after the nationalization provoked the Mexican state to impose its will and force workers to adhere to nationalist policy. Thus, dominance by foreign investors relented to the more subtle domination of the nation-state. Material improvements such as the increase in employment and higher wages strengthened the myth that a strong and sovereign Mexican state acted on behalf of the working class.

\section{Conservative Reaction}

As examined previously, the conservative reaction prompted a turn by Cárdenas and successive administrations toward more reactionary positions politically and economically. The cultural impact of the oil nationalization and the nationalist rhetoric of Cárdenas held fast. But after Cárdenas, the rhetoric of revolutionary nationalism increasingly diverged from reality and became more and more superficial. Successive presidents and political leaders espoused their connection to and respect for the Mexican Revolution and its principles. ${ }^{28}$ But while the social and economic rhetoric of revolutionary nationalism remained consistent, its execution increasingly served as a tool of capital accumulation for the benefit of the elite. As Mexico became more authoritarian, the social aims of revolutionary nationalism became increasingly superficial and transformed themselves merely into a means of legitimizing elite rule. ${ }^{29}$ The nationalist

\footnotetext{
${ }^{28}$ Camín Aguilar and Meyer, In the Shadow of the Mexican Revolution, 159.

29 Joseph and Buchenau, Mexico's Once and Future Revolution, 142, 147, 153.
} 
rhetoric of Cárdenas held. Except, it now took the form of Mexicanization, a seemingly attractive notion suggesting a new push for independence from foreign interests but devoid of the radical meaning and substance nationalization had originally conveyed.

When Mexicanization was pushed by President López Mateos and Eduardo Bustamante in 1960, the primary goal became to convince business groups in Mexico that state intervention would be used to advance their interests. With the participation of foreign investors in the picture, government officials needed to present Mexicanization as a legitimate nationalist policy to the Mexican people. So, they preserved the popular discourse of national sovereignty associated with the oil nationalization, that it would promote social well-being of the Mexican people, that the Mexican state embodied the general interest of the nation, and that workers were to play a passive role subordinate to national interests. Government officials argued that the inclusion of foreign investors would strengthen national sovereignty, and in the process, promote social and popular interests.

\section{Mexicanization of the Compañía Minera de Cananea, 1971}

Ten years after the passage of the Mexicanization of mining law, President Luis Echeverría declared the Mexicanization of the Compañía Minera de Cananea on August 27, 1971. Where the Mexicanization of mining in 1961 
represented the "culmination of nationalist policy," 30 the Mexicanization of the company in Cananea represented the culmination of Mexicanization policy itself. Since the signing of the law, production had increased, internal markets had expanded, and dependence on foreign markets had declined. President López Mateos lauded the modification and restructuring of mining property on behalf of national interests. State intervention had increased the availability of public funds, sources of employment, the viability of mining operations, and the desirability of private investors to participate in the industry. The state also provided opportunities for the private sector by permitting Mexican companies to take over majority ownership through the purchase of shares. ${ }^{31}$ Clarifying the new policy, Robert Wallace Hall stated, "the "greater nationalism" of Mexicanization aims to strengthen Mexican capitalism without harming the basic interests of foreign investors." 32

The first decade of Mexicanization was its most transformative and nearly all major mining companies were Mexicanized. According to Sariego, the peak year for the Mexicanization of mining process was 1963. In that year, hundreds

\footnotetext{
${ }^{30}$ Robert B. Wallace Hall, La dinámica del sector minero en México, 1877-1970 (México: El Colegio de México, 1972), 126.

31 "El Lic. Adolfo López Mateos, al abrir el Congreso sus sesiones ordinarias, el $1^{\circ}$ de septiembre de 1961," Informe del Presidente Adolfo López Mateos September 1, 1961

(http://www.biblioteca.tv/artman2/uploads/1961.pdf), 792; Wallace Hall, 138; Adolfo López Mateo, "El Lic. Adolfo López Mateos, al abrir el Congreso sus sesiones ordinarias, el $1^{\circ}$ de septiembre de 1964," Informe del Presidente Adolfo López Mateos, September 1, 1964, (http://www.biblioteca.tv/artman2/uploads/1964a.pdf), 851; Editorial, "La Empresa Minera de Cananea, Mexicanizada," El Nacional, August 30, 1971.

32 Wallace Hall, 207.
} 
of new companies were established and 150 existing companies, including three large mining companies, complied with the new policy. ASARCO, for instance, the largest copper company in operation besides Cananea, Mexicanized itself in 1966. According to Wallace Hall, mining production by Mexicanized companies reached $90 \%$ in $1969 .{ }^{33}$ At the end of the decade, the Compañía Minera de Cananea remained the last large mining enterprise still under foreign control.

Mineworkers in Cananea expected national control of mineral resources to bring them benefits, but early steps toward the Mexicanization of the $\mathrm{CMC}$ were nominal. On December 31, 1960, the company changed its name to the Compañía Minera de Cananea. ${ }^{34}$ This included an increase in the company's total capital stock, but neither the ownership nor management of the company changed. ${ }^{35}$ The name change was immediately met with suspicion from workers and regarded as a way to conceal the lack of substantive transformation within the company. ${ }^{36}$ Nonetheless, in its early years workers in Cananea expected positive changes to come from the policy of Mexicanization, particularly better job security and a higher standard of living. They had witnessed the benefits of

\footnotetext{
${ }^{33}$ Sariego, et al., El estado, 253.

${ }^{34}$ Letter from C.P. Donohoe, President of Board of Directors, Folder: MS 1032, Series II, Folder 70, "Company History." Arizona Historical Society, Tuscon, Arizona, Univ. of Arizona; MS 1032, Cananea Consolidated Copper Co. Records, 1898-1969; Box 4 of 5; Folders 57-80; Untitled note, Folder: MS 1032, Series V, Folder 86, "Company Notices, 1911-1961." Box: MS 1032; Cananea Consolidated Copper Co. Records; Box 5 of 5; Folders 81-98.

${ }^{35}$ Letter from C.P. Donohoe, President of Board of Directors, Folder: MS 1032, Series II, Folder 70, "Company History." Arizona Historical Society, Tuscon, Arizona, Univ. of Arizona; MS 1032, Cananea Consolidated Copper Co. Records, 1898-1969; Box 4 of 5; Folders 57-80.
}

36 "Cambio de Nombre," 1906, December 31, 1960. 
Mexicanization for workers at Peñoles, the first company to be Mexicanized, who had received a wage increase of $13 \%$, compared to the $5 \%$ received by workers at Cananea. ${ }^{37}$

Delays instilled disillusion with the process of Mexicanization early on. The union newspaper, the 1906: Semanario órgano oficial de la Sec. $65 \mathrm{del}$ S.I.T.M.M.S.R.M., documented the workers' dissatisfaction. When the law went into effect in April 1961, one writer, skeptical about Anaconda's willingness to comply with the new law, remarked that nothing had changed, and no change was expected in the future ${ }^{38}$ Later that year, on the anniversary of national independence, an editorialist remarked, "we see with bitter desperation as our awaited economic independence still has not come to this country." ${ }^{39}$ The continued presence of the foreign companies propagated an entrenched "colonial slave economy," that would inevitably "annihilate our resources and our wealth, annihilating also the most precious and valuable for our country, the health and strength of its children." 40 In November 1962, the companies continued to profit "at the cost of hunger and misery of a people...[who] have committed no crime more than working intensely for the good will and good living of our neighbors." 41

\footnotetext{
37 "Son Peritos Pero Inútiles," 1906, May 6, 1961; "Se Necesita mexicanizar el cobre," 1906, May 27, 1961; O.B.M., "Urge la Total Mexicanización de la Minería," 1906, June 3, 1961.

38 “En Este Mese Entró en Vigor la Nueva Ley Minera," 1906, April 29, 1961.

39 "No Tendremos Industria Propia Sin Nacionalización," 1906, September 16, 1961.

40 "No Tendremos Industria Propia Sin Nacionalización," 1906, September 16, 1961.

41 "La Revolución y el Avance de Nuestro Mineral," 1906, November 17, 1962.
} 
While Mexicanization was delayed, workers experienced worsening working conditions and new challenges after 1961. The American-owned Compañía Minera de Cananea made changes to increase productivity, introducing new heavy machinery and automating work processes. For workers, these innovations changed the nature of work, shortened vacations, and most importantly, threatened long-term employment. These innovations also challenged and circumvented existing labor guarantees indirectly by "increas[ing] responsibilities and the work of the operators." ${ }^{42}$ Labor abuses continued and were encouraged by the hiring of personnel from out of town "who have no other mission than that of despotic jailers, a vivid image of those Nazi guards of the concentration camps." ${ }^{43}$ One writer expressed the sentiment of many, that Anaconda was increasing its productivity to extract all the nation's minerals too quickly. ${ }^{44}$ "Like the horsemen of the Apocalypse, where the horde of Yankee Imperialism passes through, only misery, destruction, lament, death. . . [and] grief remain." 45 Taking national control of the copper mines from its foreign owners became a fight "for the survival" of the people of Cananea, "which does

\footnotetext{
42 "Los Jinetes del Apocalipsis," 1906, June 1, 1965; "Lucha por la Supervivencia de Este Pueblo," 1906, June 1, 1965; "Por el Tajo a Cielo Abierto," 1906, October 9, 1971.

43 "Los Jinetes del Apocalipsis," 1906, June 1, 1965; “Demagogia o Mexicanización,” 1906, Abril $17,1971$.

44 “"No Estamos Solos," 1906, January 2, 1965.

45 “Los Jinetes del Apocalipsis," 1906, June 1, 1965.
} 
not want to die and for the conquest of bread, independence, and national sovereignty." 46

For workers, national control of the mines became the key to improving their working lives. As the delay for Mexicanization lengthened, some workers began to call for the full and direct nationalization of the country's mines. In 1962, one editorialist in 1906 called for the nationalization of the entire mining industry in order to finally end imperialism, to break up large unproductive mining concessions, and to eradicate the discrimination of Mexicans in their own country. Nationalization was also seen as a restraint against unlimited increases to productivity and the exhaustion of Mexican resources, and a means to employ resources rationally at the service of the Mexican people. ${ }^{47}$ Francisco Javier López argued that Mexicanization would fail to harness national resources effectively, because it preserved the diffusion of the industry across hundreds of mining companies instead of creating a single nationalized agency to manage the entire industry. To be efficient, produce to capacity, and provide the greatest national benefits, he argued, the companies needed to be "driven as a whole, and not as a sum of companies that compete amongst themselves." ${ }^{28}$ He also

\footnotetext{
46 "Lucha por la Supervivencia de Este Pueblo," 1906, June 1, 1965. On every front page since the passage of the Mexicanization Law until August 21, 1971.

47 "La expropiación de la Ind. Minera," 1906, December 15, 1962; "No Estamos Solos," 1906, January 2, 1965; "No Tendremos Industria Propia Sin Nacionalización," 1906, September 6, 1961; "Decisión y Responsabilidad," 1906, September 9, 1961; "Llegaremos Hasta el Fin," 1906, July 3, 1965; "Lucha por la Supervivencia de Este Pueblo," 1906, June 1, 1965.

48 “ilntegrar el sector nacionalizado!" Solidaridad, Mayo 1, 1975.
} 
argued that Mexicanization concealed and sustained the dominance of private and foreign investors. ${ }^{49}$

When Luis Echeverría became president in 1970, he sought to revive the use of state intervention for direct social improvements. There was a clear economic crisis and social tension prevailed among many sectors of Mexican society left out of the Mexican Miracle. At this point, the state had essentially lost the popular base established by Cárdenas and had devolved to the interests of domestic and foreign capital that had grown powerful during the presidencies of Miguel Alemán (1946-1952) and Adolfo Ruiz Cortines (1952-1958). To restore the autonomy of the state, President Echeverría tried to create a new "sociopolitical base" by resurrecting the Cardenista tactic of mobilizing workers, peasants, and middle classes, which eventually led to the creation of the Popular Alliance, a multiclass political coalition intended to secure governance.$^{50} \ln$ reaction, "business and political groups. . were joined by official unions and major landowners in a campaign to resist Echeverría and to sabotage the economy." 51 Similar to Cárdenas, he was opposed from many sides and forced to mitigate his stances. So, when Echeverría announced the Mexicanization of

\footnotetext{
${ }^{49}$ Francisco Javier López, "Por la Creación de la Corporación Nacional Minero-Metalúrgica," Solidaridad, October 31, 1971.

50 Jorge Basurto, "The Late Populism of Luis Echeverría," in Latin American Populism in Comparative Perspective, ed. Michael L. Conniff (Albuquerque: University of New Mexico Press, 1982), 105.

${ }^{51}$ Basurto, "The Late Populism," 107.
} 
the $\mathrm{CMC}$, his effort represented one of the last gasps of revolutionary

nationalism. ${ }^{52}$

The Mexicanization of the Compañía Minera de Cananea was announced on August 27, 1971 in a ceremony presided over by President Luis Echeverría, Secretary of National Patrimony Horacio Flores de la Peña, and Anaconda president and CEO John B.M. Place. A formality more than anything else, the assembly declared Anaconda's intent to sell $51 \%$ of shares to domestic investors which included five groups: the Comisión de Fomento Minero (13\%), Nacional Financiera (13\%), Cobre de México (9.81\%), Banco Nacional de México (9.81\%), and the workers and employees of the CMC (5.38\%). Anaconda would own the remaining $49 \%$, the maximum allowed by the law. ${ }^{53}$

Mexicanization was presented as an improved form of nationalism, described by Secretary Flores de la Peña as "a healthy and balanced nationalism." ${ }^{54}$ Through the new capital requirement, Mexicanization transferred

\footnotetext{
52 Basurto, "The Late Populism," 96-97, 107-108.

53 "Oficialmente Informan a sus Trabajadores y Empleados la Mexicanización de Cía Minera de Cananea, S.A. de C.V." El Heraldo de Cananea, August 27, 1971; September 4, 1971; José Manuel Jurado, "La Compañía Minera de Cananea Controlada por Mexicanos," Ultimas Noticias, August 27, 1971; "El Gobierno Adquiere las Acciones Mayoritarias de Cananea," El Heraldo de México, August 28, 1971; Leopoldo Mendívil, "Con la Nacionalización del Cobre, México es Dueño de los Productos Esenciales del Subsuelo," El Heraldo de México, November 16, 1971; J.R. Gámez Terán, "Control Total del Cobre al ser Mexicanizada "Cananea,"' Novedades, August 28, 1971; "A Propósito de la Mexicanizacíon de la Empresa Minera Local," El Heraldo de Cananea, September 1, 1971; Gabriel Perales, "México busca consolidar una economía más independiente," Avance, August 28, 1971; Luis Echeverría A., "Primer Informe de Gobierno," September 1, 1971. Seis Informes de Gobierno. Estados Unidos Mexicanos: Secretaría de la Presidencia, Direccíon General de Documentación e Informe Presidencial, 1971, September 1, 1971 (http://www.biblioteca.tv/artman2/uploads/1971.pdf), 23; Jesús Morales Tapia, Los Campos Mineros de Cananea (México: Compañía Minera de Cananea, 1985), 88, fn. 3.
}

54 "Prosperidad Minera," El Nacional, August 26, 1970. 
the majority of the company to Mexican ownership without subjecting the economy to any major disruptions like those experienced after the nationalization of the oil industry. Also central to this "healthy and balanced nationalism," was the participation of foreign capital. Flores de la Peña argued that the presence of foreign investors in a minority position was a convenient relationship that maintained access to international markets, good credit standing, and access to imports of technology and machinery. The takeover of mines through a gradual process also increased the credibility of Mexico as a workable business partner while strengthening the nation's economic independence. ${ }^{55}$ One editorialist claimed that efforts to advance the common good demanded better efforts by private and state initiative to become "complementary rather than contradictory forces." 56

Mexicanization was a nationalist policy that sought to preserve good will and good relationships with foreign capital. In the second half of the 1960s, Mexican officials increasingly desired the Mexicanization of the $\mathrm{CMC}$ in order to complete the integration of the nation's copper industry. Instead of using threats

\footnotetext{
55 "México Rescata el Cobre Como Producto Básico Para su Desarrollo," El Nacional, August 28, 1971; "Hacia un Nuevo Auge Minero," El Nacional, August 11, 1971; "Aprobó LE el Plan Para Mexicanizar la Compañía Minera de Cananea, la más Importante Productora de Cobre del País," El Nacional, August 28, 1971; Alberto Cañas G.,"Consumó LEA la Total Mexicanización de la Minería," Ovaciones, August 28, 1971; Gabriel Perales, "México busca consolidar una economía mas indendiente," Avance, August 28, 1971; José Manuel Jurado, "La Compañía Minera de Cananea Controlada por Mexicanos," Ultimas Noticias, August 27, 1971; "Se Formalizó la Mexicanización de la Compañía Minera de Cananea," El Universal, November 16, 1971; "La Empresa Minera de Cananea, Mexicanizada," El Nacional, August 30, 1971; Editorial, "Mexicanización de la Mineriá," El Sol de México, August 29, 1971.

${ }^{56}$ Editorial, "Mexicanización de la Mineriá," El Sol de México, August 29, 1971.
} 
to spur Anaconda's compliance, the government offered more incentives. In 1968, the government specifically targeted Anaconda when it extended a "special automatic subsidy of $50 \%$ to producers." ${ }^{57}$ Yet, the final decision to Mexicanize came from the executives of Anaconda themselves. On December 31, 1969, the company released a study on the benefits of Mexicanization and included a plan for carrying it out. The Wall Street Journal indicated that Anaconda's executives were actively moving forward with the plan on May 20, 1971. Anaconda's President and CEO John B. M. Place himself professed that Mexicanization was not a coerced, but a voluntary decision. ${ }^{58}$ This contrasted with the company's recent experience.

Anaconda's greatest concerns at the time involved its properties in Chile, which far surpassed Cananea in production and value. In the early 1900s, the Kennecott Copper Company and the Anaconda Copper Mining Company began operations at three mines - El Teniente, Chuquicamata, and Potrerillos. Copper soon replaced nitrates to become the foundation of the Chilean economy and a critical source of government revenue by the 1950 s. ${ }^{59}$

\footnotetext{
57 Sariego, 1986, 418.

58 "Datos Generales Sobre la Compañía Minera de Cananea, Información de Prensa," Folder: MS 1032, Series II, Folder 70, "Company History; " Arizona Historical Society, Tucson Arizona, Univ. of Arizona; MS 1032; Cananea Consolidated Copper Co. Records; 1898-1969; Box 4 of 5; Folders 57-80, 5; "Anaconda Co. Meeting Centers on Operations Outside South America," Wall Street Journal, May 20, 1971; Gene Smith, "Parkinson to Quit as Chairman of Anaconda Company Oct. 28," New York Times, October, 1971; "Critica la Política Minera de México," El Informador, March 4, 1961.

59 Simon Collier and William R. Sater, A History of Chile, 1808-1994 (Cambridge: Cambridge University Press, 1996), 160-161, 203, 268-269, 281.
} 
To gain control of its copper resources and increase government revenue, the administration of President Eduardo Frei adopted the policy of Chileanization. Kennecott agreed with the plan right away, in December 1964, but Anaconda waited for another five years. In 1969, Anaconda sold $51 \%$ of the shares in each of its two affiliates: Chile Exploration and Andes Mining. The remaining 49\% was to be sold at the end of 1972; compensation payments would be completed by 1982. Frei lauded the moderate character of this nationalist process: "[t]he country has not suffered, nor will it have to suffer upheavals nor violence, neither has it compromised its international credit." ${ }^{60}$ Chileanization preserved a cooperative relationship with Anaconda, which "committed to maintain the rhythm of planned investments, and. . provide due technical assistance." ${ }^{61}$ The next president quickly upended this approach. ${ }^{62}$

On December 21, 1970, President Salvador Allende presented a constitutional amendment, which permitted the nationalization of Chile's copper mines. Chilean leaders criticized Anaconda and other multinational corporations for exploiting natural resources without bringing lasting national development. Repossessing the mines, it was claimed, would bring economic improvement, shield national enterprises from international markets, and steer production

\footnotetext{
60 “Hecha la Nacionalización del Cobre, Anuncia Frei," Novedades, June 27, 1969.

61 "Chile Tomó el Control de su Cobre," Novedades, July 1, 1969.

62 Collier and Sater, History of Chile, 308, 315, "Lo Celebró con la Anaconda Copper Co.," El Nacional, June 27, 1969; "Chile Tomó el Control de su Cobre," Novedades, July 1, 1969;

Editorial, "El Cobre Chileno, Nacionalizado," El Nacional, n.d.
} 
toward national interests. ${ }^{63}$ Anaconda had already agreed to nationalization in 1969, so the major effect of the pronouncement involved the amount of compensation owed. Allende determined that "instead of being entitled to compensation, Anaconda and Kennecott should pay the state US\$78 million and US\$310 million respectively." 64 On July 11,1971 , the Chilean congress approved the constitutional amendment sent by President Allende to nationalize the mines, and as a result, the date became celebrated as the Day of National Dignity. ${ }^{65}$ For Anaconda, the loss portended the company's decline. ${ }^{66}$ In contrast to direct nationalizations such as the Chilean one, the Mexicanization of mining succeeded as a nationalist policy intended to preserve the goodwill and support of foreign investors. What had previously "seemed an extreme measure," ${ }^{67}$ began to appear moderate and beneficial for foreign investors. R. H. MacWilliam, president of San Francisco Mines of Mexico

\footnotetext{
63 "Presentarán al Congreso de Chile una Reforma Constitucional para Nacionalizar el Cobre," El Nacional, December 1, 1970; "El Cobre, de Chile," Excélsior, December 22, 1970; "Chile Controla ya las 5 Principales Minas de Cobre," Excélsior, July 14, 1971; Mariano Mora, "Chile y su Cobre," El Nacional, June 30, 1969; "Chile Nacionaliza al Cobre y Proclama la Dignidad Nacional," El Universal, July 12, 1971; R. Torres Barrón, "Sin Independencia Económica, la Política es un Disfraz: Hugo Vigorena," Excélsior, July 15, 1971.

${ }^{64}$ Collier and Sater, History of Chile, 334-335; "El Cobre, de Chile," Excélsior, December 22, 1970.

65 "Chile Nacionaliza al Cobre y Proclama la Dignidad Nacional," El Universal, July 12, 1971; Editorial, "Chile: la Batalla del Cobre," Excélsior, October 11, 1972; "El Cobre de Chile," El Universal, July 13, 1971.

66 "El Cobre de Chile," El Universal, July 13, 1971; "el "Dia de la Dignidad Nacional." July 11, 1971; "Chile Nacionaliza al Cobre y Proclama la Dignidad Nacional," El Universal, July 12, 1971; "Apoyo a los Chilenos," Excélsior, October 12, 1972.

${ }^{67}$ Alan Riding, “Mexicanization Process Ends," New York Times, September 19, 1971.
} 
defended Mexicanization as a reasonable nationalist policy, without incurring the expense of local and foreign investors. Lucien Sermon, president of the Belgian delegation to the XIX Congress of the Chamber of International Commerce, affirmed Mexico's amenability to investment, owing to its political and financial stability and its adherence to the "rule of law, even in the case of expropriations." 68 Contrary to the fears of its early opponents, the policy of Mexicanization yielded no impediments to foreign financing. In the New York Times, Alan Riding affirmed that after decades of stagnation, Mexicanization had "stimulated an upsurge in investment, much of it from abroad."69 Gradually, even foreign investors saw Mexicanization as a guarantee against expropriations and nationalizations that preserved their access to mineral resources while benefiting from access to state resources. ${ }^{70}$

In contrast to its experience in Chile, Anaconda's executives welcomed Mexicanization as a practical business decision. Largely due to the loss of its Chilean properties, the Mexicanization of the CMC coincided with Anaconda's decline and its transformation into "a smaller, leaner Anaconda Company." Complying with the Mexicanization law entitled the company to receive

\footnotetext{
68 "La Política de Mexicanización, Garantía al Capital Extranjero," El Nacional, April 29, 1963.

${ }^{69}$ Alan Riding, "Mexicanization Process Ends," New York Times, September 19, 1971.

70 "Gran Visión del Gobierno al Mexicanizar la Minería," 1906, August 27, 1963, quote from Banco Nacional de México report; "Rápida Definición de Minerales y Areas que Puedan Industrializarse," El Nacional, November 12, 1962; Alan Riding, "Mexicanization Process Ends," New York Times, September 19, 1971.

${ }^{71}$ Eugene C. Tidball, "What Ever Happened to the Anaconda Company?" Montana 47, no. 2 (1997): 62.
} 
incentives, largely in the form of tax reductions. ${ }^{72}$ Company president John

Place commended the hybrid nature of Mexicanization as a policy that

encouraged Mexican development by not alienating foreign investors who feared

the nationalization of their properties in Latin America. According to Alan Riding,

in the New York Times, "foreign interests recognized the difference between this

policy of "institutionalized nationalism" and the waves of nationalism sweeping

parts of South America." ${ }^{73}$ When asked to compare Mexicanization with the

nationalization of Anaconda's properties in Chile, Place responded that they were

like "night and day." 74

Anaconda pledged to cooperate with the newly-Mexicanized company.

Anaconda's Vice-president Paul S. Bilgore announced his desire "to keep

\footnotetext{
72 J. Rubén Velasco, "A Digest of Mining in Mexico," Folder: MS 1033, Series II, Folder 18, "Cananea Consolidated Copper Company, 1920-1969," Arizona Historical Society, Tuscon, Arizona, Univ. of Arizona; MS 1033; Robert F. Torrance Papers, 1898-1985; Box 2 of 4; f.12-f.27 (December 9, 1964), 5.

"Incentives granted to Mexicanized companies:

1. 50 to $100 \%$ ( $50 \%$ is automatic) reduction of federal production and export taxes.

2. Reduction of income tax Schedules II and VII up to $40 \%$ on new operations or the renewal of operations on properties that have not been worked for ten years or more.

3. Reduction up to $10 \%$ on Income Tax, Schedules II and VII, on long range prospecting and exploration programs.

4. Accelerated depreciations schedules on new investments in machinery and equipment.

5. Exemption of production, export and import taxes, and of income and mercantile revenue taxes for five years, and more in cases of new concssions that benefitiate necessary non-metallic products."

${ }^{73}$ Alan Riding, "Mexicanization Process Ends," New York Times, September, 19, 1971.

${ }^{74}$ Alan Riding, "Government inspired expansion underway," Financial Times, September 2, 1971; Cesar Silva Rojas, "Magnifica es la fórmula para la mexicanización," La Prensa, August 28, 1971."Mexicanizada, la Industria Minera de Cananea," El Sol de México, August 28, 1971;

"Dimensión de Nuestra Lucha," 1906, April 1, 1961; José Manuel Jurado, "Anaconda no fue obligada a Mexicanizase, lo Hizo Espontáneamente, dijo su presidente in Nueva York," Excélsior, August 28, 1971.
} 
cooperating in its [Mexico's] economic development, associated with local interests." ${ }^{75}$ In contrast to the oil nationalization, investments continued and facilities expanded. Secretary Horacio Flores de la Peña (SEPANAL) projected an investment of 24 million pesos between 1972 and 1974 to increase production to 65,000 tons per year. Anaconda stated its desire to continue with plans for a two-stage expansion of the company's facilities. The first saw an investment of 300 to 400 million pesos to double copper production in five years; the second included an investment of 2,000 million pesos to double production to nearly 140,000 tons of copper annually. ${ }^{76}$ The preservation of foreign investment in the mining industry thus, possessed a significant role in the achievement of national sovereignty.

Upon hearing the news of Mexicanization, the workers and townspeople of Cananea celebrated "the end of seventy years of economic submission to a foreign company." ${ }^{" 77}$ This concluded a struggle sustained over generations by the "descendants of the martyrs of Cananea" and the "heroic miners who ignited the

\footnotetext{
${ }^{75}$ Cesar Silva Rojas, "México posee el 51 por ciento de las acciones," La Prensa, August 28, 1971.

${ }^{76}$ Michael C. Jensen, "Anaconda to Sell Mexico 51\% of Its Cananea Mine," New York Times, August 28, 1971; Alan Riding, "Mexicanization Process Ends," New York Times, September 19, 1971; Alberto Cañas G., "Consumó LEA la Total Mexicanización de la Minería," Ovaciones, August 28, 1971; "Fue Mexicanizada la Empresa Minera de Cananaea; Se Nombró Nuevo Consejo," Ovaciones, November 16, 1971; Alan Riding, "Government inspired expansion underway," Financial Times, September 2, 1971; "Aprobó LE el Plan Para Mexicanizar la Compañía Minera de Cananea, la más Importante Productora de Cobre del País. El Nacional, August 28, 1971; "La Empresa Minera de Cananea, Mexicanizada," El Nacional, August 30, 1971; "Dimensión de Nuestra Lucha," 1906, April 1, 1961.

77 Agustín Perez M., "Explosión de Júbilo Hubo en Cananea," El Nuevo Sonorense, August 28, 1971.
} 
flame of the Mexican Revolution"78 They also celebrated the final recovery of their national patrimony with the expectation that it would benefit "the miner, his family and the population in general." ${ }^{" 9}$ Municipal president Roberto Elzy Torres hinted, "now that its principal source of work will be operated from a Mexican and nationalist point of view," Cananea's future prosperity would be achieved. ${ }^{80}$

Despite the preservation of foreign interests, workers and state officials alike presented the Mexicanization of Cananea's mines as an achievement of national sovereignty and economic independence. They considered the change a national victory, the joyous culmination of a struggle against foreign exploitation that began with the arrival of the Spanish conquistadors. The leader of the national mining union, Napoleón Gómez Sada, for instance, stated that the Mexicanization of the CMC had been a "trial of the concerns of all Mexicans to conquer the full economic independence of our country." ${ }^{\text {11 }}$ Secretary Flores de la Peña confirmed this sentiment, declaring that Mexicanization combined "the necessitities of economic development and popular aspirations and corresponded to the permanent desire of the current government to affirm our

\footnotetext{
78 "Agradeciemiento de Sonorenses a LE por la Mexicaniczación en Cananea," Excélsior, August 28, 1971.

79 "Aplauden Pueblo y Gobierno de Sonora la Mexicanización de la Minera de Cananea," El Heraldo de México, August 28, 1971.

${ }^{80}$ Agustín Perez M., "Explosión de Júbilo Hubo en Cananea," El Nuevo Sonorense, August 28, 1971.

81 Sindicato Industrial de Trabajadores Mineros, Metalúrgicos y Siderúrgicos de la Republica Mexicana, Letter to Luis Echeverría Alvarez, El Nacional, August 29, 1971.
} 
economic independence." 82 The main working class newspaper in Cananea, regarded the Mexicanization of the $\mathrm{CMC}$ as representing "an alternative for our economic development," an alternative that involved not foreign control but national control, and not mere economic exploitation and productivity but the implementation of social goals as well. ${ }^{83}$

In contrast to the oil nationalization, the aspiration of national control through Mexicanization did not entail isolation from foreign investors or markets. Mexicanization steered mineral resources toward domestic industries and emphasized their rational exploitation, but participation in international markets and cooperation with foreign investors remained essential to internal development. Exports comprised a key facet of development, critical to securing and strengthening the country's economic independence. No longer, however, would these exports consist of raw mineral resources, but would consist of manufactured goods with added value. The revenue from exports would reinforce the benefits of Mexicanization through increased employment, wages, and long-term economic stability. Thus, the nationalist orientation of Mexicanization included a definitive, outward orientation, and represented a key factor in nurturing resiliency against international market forces and foreign investors. Mexicans wanted the "equitable cooperation with foreign capital as complementary to that of Mexican [capital]." ${ }^{84}$ According to these views, national

\footnotetext{
82 J.R. Gámez Terán, "Control Total del Cobre al ser Mexicanizada "Cananea," Novedades, August 28, 1971.

83 “Burocratización," 1906, August 12, 1972.
} 
sovereignty would be achieved and strengthened by maintaining ties to foreign investors and working within the international system.

Despite the participation of foreign investors, government officials presented Mexicanization as a step toward economic independence that would promote national interests. After the Mexicanization of the CMC, President Echeverría proclaimed, "mining development is subordinated to the general interest of the nation." ${ }^{85}$ With sovereign control of resources, Mexico would no longer be at the mercy of foreign suppliers. The President claimed that the outward and irreversible flow of resources and profits would be halted and redirected for the Mexican economy. ${ }^{86}$ Director of Nacional Financiera, Guillermo Martinez Domíngez defended state intervention by citing the "imperative of national sovereignty" to transform the company's purpose toward domestic industries, the creation of jobs, and the preservation of the social order. $^{87}$ Thus, parastate enterprises embodied national sovereignty and guaranteed that the conservation and exploitation of mineral resources would benefit the Mexican people. Economic development would not just increase

\footnotetext{
84 “La Empresa Minera de Cananea, Mexicanizada," El Nacional, August 30, 1971.

${ }^{85}$ Luis Echeverría A., "Segundo Informe de Gobierno," September 1, 1972. Seis Informes de Gobierno. Estados Unidos Mexicanos: Secretaría de la Presidencia, Direccíon General de Documentación e Informe Presidencial, 1972, September 1, 1972, (http://www.biblioteca.tv/artman2/uploads/1972.pdf), 48.

${ }^{86}$ Luis Echeverría A., "Primer Informe de Gobierno," September 1, 1971. Seis Informes de Gobierno. Estados Unidos Mexicanos: Secretaría de la Presidencia, Direccíon General de Documentación e Informe Presidencial, 1971, September 1, 1971 (http://www.biblioteca.tv/artman2/uploads/1971.pdf), 23.

87 "El Porqué de las Empresas Estatales," Heraldo de México, November 19, 1971.
} 
GDP and wealth but extend to all aspects of Mexican society for "the adequate redistribution of national income." 88

The recovery of mineral resources was more than the accumulation of wealth: it also represented the recovery of national patrimony and pride. Luis de la Peña Porth, undersecretary of SEPANAL, claimed that control of the Compañía Minera de Cananea was the final step in regaining Mexico's mineral wealth. Once completed, the mining industry can begin to progress "with the support of the entire people, owner of our resources, we expect to increase our patrimony." ${ }^{89}$ Sovereign control over natural resources became a source of national pride, a nationalist purification that began to erase the ignominy and humiliation of Porfirismo, and provide the foundation for Mexico to affirm its own destiny and establish political independence, according to Senator Enrique Olivares Santana..$^{90}$ For the political leaders of the country, sovereign control of resources conveyed associations beyond the purely economic realm and included notions of justice, sovereignty, dignity, autonomy, individual and national self-realization. President López Mateos appealed to the exploitation of copper as the cultivation of the nation's patrimony: "Our prosperity must support the

\footnotetext{
${ }^{88}$ Alberto Cañas G., "Consumó LEA la Total Mexicanización de la Minería," Ovaciones, August 28, 1971.

89 "Opiniones Respecto al Primer Informe," El Informador, September 2, 1971.

90 Augusto Focil Díaz, "15 mil Pesos Costó Cananea," El Sol de México, August 29, 1971;

"Solidaridad de la Gran Comisión del Senado con la Vigorosa Acción Nacionalista del Presidente Régimen," El Nacional, August 29, 1971; Gabriel Perales, "México busca consolidar una economía mas independiente," Avance, August 28, 1971; "Mexicanizada, la Industria Minera de Cananea: El Subsuelo Totalmente en Manos Nacionales," El Sol de México, August 28, 1971;

Editorial, "Mexicanización de la Mineriá," El Sol de México, August 29, 1971.
} 
harmonic employment of our natural, human, technical, and financial resources, to create an abundance that strengthens and integrates a healthy economy, elevates human life, and assures the independent and sovereignty existence of the nation."11

Although Mexicanization affirmed national control, the role to be played by workers would be passive and indirect. There would be no decision-making or control of the workplace by workers. The social ends of the policy would be accomplished by providing employment. Mexicanization would strengthen and secure employment by implementing policies focused on production. Mexicanization also gave workers the opportunity to purchase shares and own part of the company. Workers could make payments through regular paycheck deductions over a period of "five years without interest and with rights to the dividends."92 Public opinion viewed employment as a means for private investors to contribute to national well-being and allow workers "to participate in the common patrimony." ${ }^{93}$ Pedro Reyes Zuñiga, the local Secretary of Labor within Section 65 , criticized the effort because the number of shares purchaseable by

\footnotetext{
${ }^{91}$ Adolfo López Mateos, "El Lic. Adolfo López Mateos, al abrir el Congreso sus sesiones ordinarias, el $1^{\circ}$ de septiembre de 1960," Informe del Presidente Adolfo López Mateos. September 1, 1960 (http://www.biblioteca.tv/artman2/uploads/1960.pdf), 737.

92 Sotero R. Garciasreyes, "El Control de la Minera de Cananea en Manos Mexicanas," El Heraldo de México, November 16, 1971; E. T. Q., "Armando Hopkins, Consejero de La Compañía Minera de Cananea." El Sonorense, November 17, 1971; "Oficialmente Informan a sus Trabajadores y Empleados la Mexicanización de Cía Minera de Cananea, S.A. de C.V."El Heraldo de Cananea, September 4, 1971.

93 "La Industria Minera no Está en Decadencia: José Campillo Sáinz," El Heraldo de México, November, 191971.
} 
workers (between $3 \%$ and $5.88 \%$ ), represented no harm to the companies and were a small portion compared to the majority position held by other shareholders. Workers primarily became interested in the possibility of ownership as a way to preserve employment. ${ }^{94}$ Despite their indirect and passive role, editorialist Cesar Silva Rojas claimed otherwise, arguing that mine workers were now "owners of their own advancement" and servants of the nation since they would work "now to triple their production in the interest of Mexico."95 After the Mexicanization of the CMC, President Echeverría appealed to workers to subordinate their interests to those of the nation. He implored them "to keep working with the intensity and patriotism as you have done until now" for the purpose of reinforcing and strengthening "the economy of Mexico." ${ }^{\text {" }}$ The union leaders of Cananea accepted the challenge, and proclaimed, "we will keep

\footnotetext{
94 "La Industria Minera no Está en Decadencia: José Campillo Sáinz," Heraldo de México, November 19, 1971; "Aprobó LE el Plan Para Mexicanizar la Compañía Minera de Cananea, la más Importante Productora de Cobre del País," El Nacional, August 28, 1971; "México Rescata el Cobre Como Producto Básico Para su Desarrollo," El Nacional, August, 28, 1971; "Mexicanizada, la Industria Minera de Cananea," El Sol de México, August 28, 1971; "Aplauden Pueblo y Gobierno de Sonora la Mexicanización de la Minera de Cananea," El Heraldo de México, August 28, 1971; "Por el Tajo a Cielo Abierto," 1906, October 9, 1971; "Total Apoyo de Sonorenses a LE por Mexicanizar las Minas de Cananea, "La Prensa, August 28, 1971; "Agradecimiento de Sonorenses a LE por la Mexicanización en Cananea," Excélsior, August 28, 1971; "Oficialmente Informan a sus Trabajadores y Empleados la Mexicanización de Cía Minera de Cananea, S.A. de C.V.". El Heraldo de Cananea, September 4, 1971; Pedro Reyes Zuñiga, Sría. General de Trabajo, "Comunicación del Comité Ejecutivo General a la Sría. Loc. del Trabajo.” 1906, November 20, 1971.

${ }^{95}$ Cesar Silva Rojas, "México pose el el 51 por ciento de las acciones," La Prensa, August 28, 1971; Editorial, "Mexicanización de Cananea," Novedades, November 17, 1971; "La Empresa Minera de Cananea, Mexicanizada," El Nacional, August 30, 1971.

96 José Manuel Jurado, "La Compañía Minera de Cananea Controlada por Mexicanos," Ultimas Noticias, August 27, 1971; "La Mineria en Manos Mexicanas," Ovaciones, August 27, 1971; "Mexicanizada, la Industria Minera de Cananea" "El Subsuelo Totalmente en Manos Nacionales" El Sol de México, August 28, 1971.
} 
working with patriotism in production. . . without sacrificing the workers." ${ }^{\text {97 }}$ Thus, temporarily at least, Mexicanization mitigated labor radicalism and precluded further calls for nationalization. According to President Echeverría, "The labor movement has contributed vigorously to the growth of the economy, to the nationalization of our natural resources, and to the achievements reached toward social justice. Without their combative action the contemporary institutions of Mexico would be incomprehensible." ${ }^{98}$ Workers had previously played a direct and participatory role in advancing the goal of national sovereignty. With national sovereignty achieved, government officials expected workers to contribute as a mere factor of production, subservient to national interests. ${ }^{99}$

For many, the Mexicanization of the CMC in 1971 was a moment that signified the closure of a long historical process. The national mining union published a full page letter in national newspapers praising President Echeverría for having "accelerated the nationalist process that began, precisely in Cananea, in the year 1906."100 J. R. Gámez Terán wrote that that Echeverría's

\footnotetext{
${ }^{97}$ Sindicato Industrial de Trabajadores Mineros, Metalúrgicos y Siderúrgicos de la Republica Mexicana, Letter to Luis Echeverría Alvarez, El Nacional, August 29, 1971.

${ }^{98}$ Luis Echeverría A., "Tercer Informe de Gobierno," September 1, 1973. Seis Informes de Gobierno. Estados Unidos Mexicanos: Secretaría de la Presidencia, Direccíon General de Documentación e Informe Presidencial, 1973, September 1, 1973 (http://www.biblioteca.tv/artman2/uploads/1973.pdf), 75.

${ }^{99}$ Faustino Félix Serna, Governor of Sonora, "C. Lic. Don Luis Echeverría Alvarez, Presidente Constitucional de los Estados Unidos Mexicanos, Palacio Nacional," Ovaciones, August 27, 1971, Special Bulletin/Letter; "Júbilo en Sonora por el Acuerdo del Presidente," Ovaciones, August 28, 1971; "En Este Mese Entró en Vigor la Nueva Ley Minera," 1906, April 29, 1961; "Piden sea Nacionalizada la Minera de Cananea," El Informador, September 9, 1961.

100 Sindicato Industrial de Trabajadores Mineros, Metalúrgicos y Siderúrgicos de la Republica Mexicana, Letter to Luis Echeverría Alvarez, El Nacional, August 29, 1971.
} 
administration "settled a debt yesterday with both the initiators of the Revolution and organized syndicalism in Mexico."101 The Mexicanization of Cananea cast Echeverría in a more revolutionary light, and garnered comparisons with Lázaro Cárdenas. The writers of 1906 described him as the leader of "a Revolutionary government [who] signed in peace what those visionaries began with their blood." 102 Mexicanization signified "the recovery of the dignity of a people, finally liberating them from foreign tutelage, [and] initiating a new era for Cananea."103

Government officials such as Horacio de la Peña described the Mexicanization of the $\mathrm{CMC}$ as the achievement of total control of the mining industry. ${ }^{104}$ During the legislative phase of Mexicanization, many editorials and newspapers carefully distinguished Mexicanization from nationalization, but with respect to Cananea in 1971, the differences were more often conflated. Mexicanization was inaccurately referred to as nationalization, although it more accurately corresponded to a termination of majority foreign ownership rather

\footnotetext{
101 J.R. Gámez Terán, "Control Total del Cobre al ser Mexicanizada “Cananea,"” Novedades, August 28, 1971.

102 "Primer Aniversario de la Mexicanización de la Cía. Minera de Cananea," 1906, August 26, 1972; "Los Mártires de 1906, La Libertad de Imprenta y ¡RET!” 1906, June 3, 1972; Editorial, "Los Ideales Revolucionarios," El Heraldo de México, August 31, 1971.

103 "Nueva Era Para Cananea," El Nuevo Sonorense, August 28, 1971; Rafael H. Fuentes, "Echeverria el Mejor Reflejo de Cárdenas," El Sonorense, November 17, 1971.

104 Sindicato Industrial de Trabajadores Mineros, Metalúrgicos y Siderúrgicos de la Republica Mexicana, Letter to Luis Echeverría Alvarez, El Nacional, August 29, 1971; "La Mineria en Manos Mexicanas" "Mexicanizada, la Industria Minera de Cananea" "El Subsuelo Totalmente en Manos Nacionales," Ovaciones. August 27, 1971; J.R. Gámez Terán, "Control Total del Cobre al ser Mexicanizada "Cananea," Novedades, August 28, 1971; "La Mineria en Manos Mexicanas," Ovaciones, August 27, 1971; Cesar Silva Rojas, "México posee el 51 por ciento de las acciones," La Prensa, August 28, 1971.
} 
than the total exclusion of foreign participation. ${ }^{105}$ The national mining union expressed its satisfaction that Mexicanization had achieved "the full economic independence of our country."106 For President Echeverría the control of the Compañía Minera de Cananea could be added to the list of historical accomplishments achieved by the Mexican nation - independence, the Reforma, the revolution, and the oil nationalization. ${ }^{107}$ One editorialist asserted that the country's mines were "now almost totally ours." 108 Yet the subtle distinction remains: the completion of Mexicanization truly meant that the mining industry had come under the majority control of Mexican capital, nothing less, nothing more. ${ }^{109}$ Foreign companies, like Anaconda, still retained $49 \%$ of the ownership in the Compañía Minera de Cananea and in other mining ventures too.

\footnotetext{
105 "El Gobierno Adquiere las Acciones Mayoritarias de Cananea," El Heraldo de México, August 28, 1971; Leopoldo Mendívil, "Con la Nacionalización del Cobre, México es Dueño de los Productos Esenciales del Subsuelo," El Heraldo de México, November 16, 1971; Sotero R. Garciasreyes "El Control de la Minera de Cananea en Manos Mexicanas," El Heraldo de México, October 30, 1963; "Se solicita la Mexicanización de la Minería" El Nacional, October 30, 1963; "Consejo de Administración Para Cananea," Avance, November 16, 1971; "El Gobierno Adquiere las Acciones Mayoritarias de Cananea," El Heraldo de México, August 28, 1971; Leopoldo Mendívil, "El Gobierno Nacionalizó la Minera de Cananea," El Informador, August 28, 1971; Rubén Parodi, "Terminó el Dominio Extranjero de 72 Años en el Mineral de Cananea," El Nuevo Sonorense, August 28, 1971.

${ }^{106}$ Sindicato Industrial de Trabajadores Mineros, Metalúrgicos y Siderúrgicos de la Republica Mexicana, Letter to Luis Echeverría Alvarez, El Nacional, August 29, 1971.

107 Luis Echeverría A., "Primer Informe de Gobierno," September 1, 1971. Seis Informes de Gobierno. Estados Unidos Mexicanos: Secretaría de la Presidencia, Direccíon General de Documentación e Informe Presidencial, 1971, September 1, 1971

(http://www.biblioteca.tv/artman2/uploads/1971.pdf), 31.

108 "Hacia un Nuevo Auge Minero," El Nacional, August 11, 1971.

${ }^{109}$ Alan Riding, "Mexicanization Process Ends," New York Times, September 19, 1971.
} 


\section{Conclusion}

The Mexicanization of Compañía Minera de Cananea in 1971 granted Mexico full sovereign control of its mineral resources after nearly 500 years of foreign exploitation. As with the oil industry and then with mining, the securing of these resources by the state rested upon the activism of the working class, which became inscribed in Mexican history as a nationalist, anti-imperialist force. Government officials presented workers' struggles as part of a larger nationalist struggle, but workers' aspirations were rather different. For oil workers in 1938, and copper miners in both Chile and Cananea, sovereign control of resources emerged as "a way to guarantee their own political and economic sovereignty."110 With the Mexicanization of mining, it became clear that it was the securing of the nation's sovereignty that had been achieved. Despite its contributions, the Mexican working class was no longer to participate in direct political action but to contribute indirectly by working for the benefit of the nation. Cárdenas had established a narrative whereby the Mexican state embodied the general will and national sovereignty over natural resources would be used to advance the social well-being of the Mexican people. Labor willingly became subservient to the Mexican state as it imposed control over the working class. While the takeover of the Compañía Minera de Cananea represented a nationalist victory, it represented the victory of conservative forces, against the social ideals of the Mexican Revolution and of revolutionary nationalism.

\footnotetext{
110 Joanna Swanger, "Defending the Nation's Interest: Chilean Miners and the Copper Nationalization," in Workers' Control in Latin America, 1930-1979, ed. Jonathan C. Brown (Chapel Hill: University of North Carolina Press, 1997), 271.
} 


\section{CHAPTER IV \\ The Compañía Minera de Cananea, 1971-1989}

President Luis Echeverría and others claimed that the Mexicanization of the Compañía Minera de Cananea (CMC) meant the achievement of Mexico's national sovereignty over its mineral resources. It represented the culmination of a struggle that began in the 1906 strike, continued through the Mexican Revolution, and persisted until 1971. The Mexicanization of the CMC was heralded as the total control of Mexico's mineral resources by the Mexican state and its achievement of "full economic independence." 1 A review of the company after its Mexicanization reveals a more complicated situation. In contrast to the nationalization of the oil industry, Mexicanization maintained the participation of foreign investors in the mining industry. Therefore, claims that it was equivalent to full sovereignty were but mere (and hyperbolic!) cultural constructs.

The literature on the Mexicanization of the CMC largely focuses on the relationship between domestic private capitalists, foreign investors, and the Mexican state. Juan Luis Sariego, the most prolific scholar on the topic, argued that Mexicanization altered the monopoly character of the mining industry and introduced two new actors: the state and the private sector. Mexicanization also extended the participation of the Mexican state into the broader governance of Mexico, dismantling the "socio-economic imperial arrangement" of the enclave, in

\footnotetext{
1 "Primer Aniversario de la Mexicanización de la Cía. Minera de Cananea," 1906, August 26, 1972.
} 
which labor and the company had been the main components. ${ }^{2}$ In the process, the state increasingly became the mediator of labor's interests, weakening the latter's strength and legitimacy. Finally, one segment of the literature alternatively suggests that foreign investors benefited more than they suffered from Mexicanization and were able to use it to their own advantage, extending new forms of control and dependence that were more effective than direct methods of exploitation. The nationalist rhetoric of Mexicanization thus obscured the complex interactions between national and foreign entities. ${ }^{3}$

This chapter continues this study's focus on discourses and culture. But to provide a grounded material foundation for this cultural approach, I examine some of the issues and concerns of business history. This field has focused on the "historical evolution of business systems, entrepreneurs, and firms, as well as their interaction with their political, economic, and social environment." ${ }^{4}$

\footnotetext{
2 Juan Luis Sariego, Enclaves y minerales en el norte de México. Historia social de los mineros de Cananea y Nueva Rosita, 1900-1970 (México, D.F.: Ediciones de la Casa Chata, 1988), 287.

${ }^{3}$ Óscar F. Contreras and Miguel Ángel Ramírez, "Cananea: el largo camino," in Cananea: tradición y modernidad en una mina histórica, eds. Óscar F. Contreras, Alejandro Covarrubias, Miguel Ángel Ramírez, and Juan Luis Sariego Rodríguez (México, D.F.: Colegio de Sonora, 1998), 57-58; Óscar F. Contreras, La minería en Sonora: modernización industrial y fuerza de trabajo (México, D.F.: Área de Estudios sobre Historia y Sociedad - El Colegio de Sonora, 1986), 15-16; Juan Luis Sariego, Luis Reygadas, Miguel Ángel Gómez, and Javier Farrera. El estado y la minería mexicana: política, trabajo y sociedad durante el siglo xx (México, D.F.: Fondo de Cultura Económica, 1988), 11-12, 184, 186, 15-16, 360, 364; Robert B. Wallace Hall, La dinámica del sector minero en México, 1877-1970 (México, D.F.: El Colegio de México, 1972), 109, 111; Raúl Delgado Wise and Rubén Del Pozo Mendoza, "Mexicanization, Privatization, and Large Mining Capital in Mexico," Latin American Perspectives 32, no 4. (July 2005): 72; Juan Luis Sariego and Raúl Santana Paucar, "Transición tecnológica y resistencia obrera en la minería mexicana," Cuadernos Políticos 31 (January - March 1982): 22-23; Sariego, Enclaves, 292-293, 295, 299, 304-305, 313, 372-373, 287-288.
}

${ }^{4}$ Geoffrey G. Jones and Jonathan Zeitlin, "Introduction," in The Oxford Handbook of Business History, eds. Geoffrey G. Jones and Jonathan Zeitlin (Oxford: Oxford University Press, 2010), 1. 
Historians of business in Latin America have examined the social organization and relationships among business elites and, those dealing with Mexico, have examined the role of the Mexican state as an industrial entrepreneur. ${ }^{5}$ All of these inquires acquire a special character when considering foreign enterprises as agents of imperialism and foreign investment as its primary means. ${ }^{6}$

Sources related to the business history of the CMC between 1971 and 1989 were limited by a number of factors. The Archivo Legal de la CMC and the Archivo Laboral de la CMC were both destroyed in a fire in 2007 . The papers of president Luis Echeverría (1970-1976), whom argued that the Mexicanization of the $\mathrm{CMC}$ represented the achievement of national sovereignty and "full economic independence" with respect to mineral resources, remain disordered and disorganized at the Archivo General de la Nación due to lack of funding.

The evaluation of Mexicanization as a successful venture requires analyzing the consequences in terms of both elite and popular national interests. Mexicanization succeeded in turning over decades of full foreign control and

\footnotetext{
5 Jeffrey Kentor, "The Growth of Transnational Corporate Networks: 1962-1998," Journal of World-Systems Research, Special Issue: Globalizations from 'Above' and 'Below' - The Future of World Society (December 2005): xi; James P. Baughman, "Recent Trends in the Business History of Latin America." The Business History Review 39, no. 4, Special Latin American Issue (Winter, 1965): 429; Mathieu Arès and Félix G. Mostajo, "El estado empresario: Nacional Financiera durante la industrialización por sustitución deimportaciones (1934-1994)," Foro Internacional 47, no. 2 (Apr. - Jun., 2007): 201-244; Douglas Bennett and Kenneth Sharpe, "The State as Banker and Entrepreneur: The Last-Resort Character of the Mexican State's Economic Intervention, 1917-76," Comparative Politics 12, no. 2 (Jan., 1980): 165-189; Meindert Fennema and William K. Carroll, "Is There a Transnational Business Community?" International Sociology 17, no. 3 (September 2002): 393-419; Problems in the Study of the Transnational Business Community," International Sociology 19, no. 3 (September 2004): 369-378.

${ }^{6}$ Maria Innes Barbero, "Business History in Latin America: A Historiographical Perspective," Business History Review 82, no. 3 (2008): 555; Baughman, 435.
} 
permitted the entry of Mexican capitalists into the mining industry by transferring majority ownership to Mexican shareholders. Yet, the majority capital requirement offered more of an image of nationalist control while in actuality the company retained multiple connections with foreign investors that cultivated more effective forms of dependence. No longer, however, did foreign participation in the Mexican economy necessarily signify a failure to achieve national sovereignty neither did it cause immediate economic stress. It actually prevented problems associated with the nationalization of the oil industry in 1938. In addition, the Mexicanization of the CMC provided an infusion of state resources, while expansion and modernization programs improved production and promoted the integration of the mining industry.

Meanwhile, workers in Cananea expected the national control of resources to increase their well-being, through greater control of their economic and working lives. Instead of increased financial security and participation in work processes, workers continued to endure harsh working conditions, negligent managers, and job discrimination. Government discourses justified these realities in a number of ways. First, they wove an alternative narrative of success by focusing on economic indicators such as the improvements to productivity and efficiency as a result of expansion and modernization projects. Second, government officials encouraged employees by making appeals to the Mexican nation. By making appeals to the national interest, workers were expected to sacrifice and defer their own interests and well-being on behalf of the Mexican nation. Through workers' perseverance and hard work, the 
improvements to the company and to the national economy would eventually reach down to the workers. As the expectations of state sovereignty in mining diverged from workers' experience, the identification of labor and the Mexican nation, cultivated by the myth of Cananea, began to break down. This chapter demonstrates the breakdown of the social dimensions of economic norms and practices. This occurred because of the pursuit of new understandings of national sovereignty and revolutionary nationalism whereby naked economic (profit) criteria ruled supreme.

This chapter examines the achievement of national sovereignty embodied in the company in Cananea and examines the meaning of national sovereignty as it concerned workers. The first section examines questions related to the business aspect of the CMC. It examines the changes in the company's ownership as a result of Mexicanization. The second half of the chapter traces the experience of Cananea's mine workers from 1971 to 1989 . This section demonstrates the continuity of labor relations as ownership changed from foreign to Mexican ownership. It examines the expectations and the results of Mexicanization with respect to funding, modernization, changes in the nature of work, and the growing disillusion with Mexicanization as a fulfillment of the Mexican Revolution.

\section{Compañía Minera de Cananea: Ownership Structure}

When Mexicanization altered the ownership structure of the CMC, the company adopted the form of a parastate enterprise. The new parastate 
enterprise emerged as the material embodiment of national sovereignty.

Preceded by fiscal, legal, and constitutional reforms, parastate enterprises

constituted the final strategy to recover control over the nation's mineral

resources. Whereas nationalized industries such as the oil industry were wholly

owned and administered by the state, mining companies that had undergone

Mexicanization often retained foreign participation. According to Dag MacLeod, parastate enterprises lacked a formal definition, but have been generally understood as a type of enterprise "that cooperate[s] with the state without forming part of its administration. ${ }^{17}$ In contrast to the public sector, which includes "administrative managerial government services at the level of municipalities, states, and federal government," the parastate sector focused on industry including petroleum, mining, manufacturing, communications, banks, airlines, and railroads, among others. ${ }^{8}$ By 1970 , the largest and most economically significant enterprises had been integrated into the parastate sector with the exception of the CMC. ${ }^{9}$ The presidency of Luis Echeverría witnessed a dramatic increase of this sector, numbering 87 in 1970 and increasing to 493 in

\footnotetext{
${ }^{7}$ Dag MacLeod, Downsizing the State: Privatization and the Limits of Neoliberal Reform in Mexico (University Park: Pennsylvania State University Press, 2004), 33, fn1.

${ }^{8}$ Cypher, State and Capital, 128.

${ }^{9}$ Luis Echeverría A., "Tercer Informe de Gobierno," September 1, 1975. Seis Informes de Gobierno. Estados Unidos Mexicanos: Secretaría de la Presidencia, Direccíon General de Documentación e Informe Presidencial, 1975, September 1, 1975

(http://www.biblioteca.tv/artman2/uploads/1975.pdf), 145; Mark Eric Williams, Market Reforms in Mexico: Coalitions, Institutions, and the Politics of Policy Change (Lanham, Md: Rowman \& Littlefield Publishers, 2001), 61; Sariego et al., El estado, 362; James M. Cypher, State and Capital in Mexico: Development Policy Since 1940 (Boulder, Colo.: Westview Press, 1990), 97.
} 
1975. In 1981, a few years after he left office, the number of parastate enterprises reached a peak of 1,155 firms. As for mining specifically, by 1980 , the state-owned equity in 48 mining companies, 29 in which it held a majority stake. In 19 others, including Cananea, the state was in a minority position. ${ }^{10}$

The development of parastate enterprises had to negotiate three main challenges. The first challenge focused on social and popular needs. A large portion of parastate enterprises originated as foreign companies whose insolvency threatened jobs and social stability. The involvement of the state increased the viability of these companies, increased employment, and improved the control of labor by introducing the state as a mediator of labor's struggles. The second challenge involved domestic capitalists. A historically weak sector, parastate enterprises encouraged the participation of the private sector in industries that required large amounts of capital for risky, long-term endeavors, and which provided cheaper inputs for domestic industry. The third challenge focused on preserving the relationship with foreign investors, ties to the global market and access to financing and technology. ${ }^{11}$

Parastate enterprises also emerged in contrast to multinational and transnational corporations, which increasingly became a concern in the 1960s

\footnotetext{
${ }^{10}$ Homero Urías, “¿Quien Controla la Minería Mexicana?” Comercio Exterior 30, no. 9 (September 1980): 957.

${ }^{11}$ Cypher, State and Capital, 98; Nora Hamilton, The Limits of State Autonomy: PostRevolutionary Mexico (Princeton: Princeton University, 1982), 95-96; Alejandro Carrillo Castro and Sergio García Ramírez, Las Empresas Públicas en México (México: Miguel Ángel Porrúa, 1983), xi; Homero Urías, “¿Quien Controla la Minería Mexicana?” Comercio Exterior 30, no. 9 (September 1980): 957.
} 
and 1970 s as a new form of imperialism. These large corporations commanded such economic resources that they were permitted to act as virtual states with their own autonomy and sovereignty. The denomination "multinational" implied the existence of entities without territorial attachment, allowing them to evade responsibility for their conduct of business. Yet, multinationals remained closely affiliated to their countries of origin and often expressed the interests of their home countries. Their size and power meant they were able to pressure and influence developing countries, whose economic needs made them vulnerable to political manipulation. Thus, multinational corporations emerged as a new imperialist threat to the sovereignty of Mexico and other Latin American nations. ${ }^{12}$ In contrast, parastate enterprises became the embodiment of national sovereignty during this period. Yet, their nationalist veneer concealed the encroachment of foreign capital, a source of dependence and control, in subtler ways.

The Mexicanization of the CMC altered the foreign ownership of the company, nearly unchanged since its founding. As examined in the first chapter, William C. Greene had established an operating company based in Mexico on

\footnotetext{
12 "Las transnacionales frente a la soberanía estatal," El Día, July 20, 1977; Leopoldo Regalado A., "Las Transnacionales Constituyen un "Superestado,"” El Nacional, February 24, 1974; Salvador Reyes Nevares, "Corrupción Transnacional," El Nacional, May 17, 1975; José Rosso, "Multinacionales vs. Transnacionales," El Nacional, August 5, 1974; "Las trasnacionales y los países en desarrollo," El Día, March 8, 1974; Vicente Alverde, "Más de las trasnacionales," El Día, February 23, 1974; "Las empresas transnacionales," El Día, March 22, 1973; Lic. Enrique M. Loaeza Tovar, "Nacionalismo Vs. Empresas Transnacionales," El Nacional, November 6, 1972; "Las Transnacionales,"Elite de Gobernantes,"” El Universal, October 11, 1974; "Las empresas transnacionales," El Día, March 22, 1973; "Poder Transnacional," El Universal, October 20, 1975; Triunfo A Elizalde, "Severa Crítica a Transnacionales Hizo el Economista Miguel Wionzeck," Novedades, October 11, 1974; "Las empresas transnacionales," El Día, March 22, 1973.
} 
September 30, 1899, the Cananea Consolidated Copper Company, and a holding company, the Greene Consolidated Copper Company, on Feb. 10, 1900, based in West Virginia. After the 1906 strike, Greene partnered with Thomas F. Cole and John D. Ryan, associated with the Amalgamated Copper Company, with whom he formed the Greene Cananea Copper Company. The takeover of Greene's companies by Amalgamated Copper was completed in February 1907 after Greene was voted off the board of directors. In 1917, the Amalgamated Copper Company was dissolved and its subsidiary the Anaconda Copper Company, came into possession of Greene's former companies. The Cananea Consolidated Copper Company changed its name to the Compañía Minera de Cananea in 1961 but remained under the control of the Greene Cananea Copper Company as a subsidiary of Anaconda until $1971 .^{13}$

When President Adolfo López Mateos signed the Mexicanization of mining into law in 1961, the Mexican state began to loosen the monopolization of the industry by foreign investors since the beginning of the century. Mexicanization transformed the $\mathrm{CMC}$ into a hybrid entity that preserved foreign enterprise while

\footnotetext{
13 "A Brief History of Cananea," n.a., 1968, Arizona Historical Society, Manuscripts Department, MS 1032, Cananea Consolidated Copper Co. Records, 1898-1969, Box 4, Series II, Folder 70, "Company History," p. 1; Eugenia Meyer, Cynthia Radding, Martha Rocha, and Guadalupe Villa, La Lucha obrera en Cananea, 1906 (México, D.F.: Secretaría del Trabajo y Previsión Social, 1980), 32, 37, 40; Mira Wilkins, The Emergence of Multinational Enterprise: American Business Abroad from the Colonial Era to 1914 (Cambridge, Mass., Harvard University Press, 1970), 8081, 116; Marvin Bernstein "Colonel William C. Green and the Cananea Copper Bubble." Bulletin of the Business Historical Society (December 1952): 195-196; Michael J. Gonzales, "United States Copper Companies, the State, and Labour Conflict in Mexico, 1900-1910," Journal of Latin American Studies 26, no. 3 (October 1994): 675; Charles L. Sonnichsen, Colonel Greene and the Copper Skyrocket : The Spectacular Rise and Fall of William Cornell Greene Copper King, Cattle Baron and Promoter (Arcadia Publishing, 1974), 215-216, 219; Mira Wilkins, The Maturing of Multinational Enterprise: American Business Abroad from 1914 to 1970 (Cambridge, Mass., Harvard University Press, 1974), 11n.
} 
introducing the Mexican state and private capital. Anaconda sold $51 \%$ of its owning shares to Mexican buyers, and retained $49 \%$ through its subsidiary, the Greene Cananea Copper Company. At the time of its announcement, the Mexican ownership of the CMC was divided among two government entities the Comisión de Fomento Minero (13\%) and Nacional Financiera (13\%) - and two private entities - Cobre de México (5\%) and Banco Nacional de México (5\%). Twelve percent of the company went on sale to private shareholders. The remaining three percent was placed in a trust managed by the Banco Nacional de México for sale to employees and workers of the CMC. ${ }^{14}$

Established in 1934, the Comisión de Fomento Minero (CFM), that as indicated above possessed $13 \%$ of Cananea's equity shares, was tasked with providing technical assistance and financing for small- and medium-sized mining

${ }^{14}$ El Heraldo de Cananea, August 28, 1971; "Oficialmente Informan a sus Trabajadores y Empleados la Mexicanización de Cía Minera de Cananea, S.A. de C.V.," El Heraldo de Cananea, August 27, 1971; September 4, 1971; José Manuel Jurado, "La Compañía Minera de Cananea Controlada por Mexicanos," Ultimas Noticias, August 27, 1971; "El Gobierno Adquiere las Acciones Mayoritarias de Cananea," El Heraldo de México, August 28, 1971; Leopoldo Mendívil, "Con la Nacionalización del Cobre, México es Dueño de los Productos Esenciales del Subsuelo," El Heraldo de México, November 16, 1971; J.R. Gámez Terán, "Control Total del Cobre al ser Mexicanizada "Cananea,"' Novedades, August 28, 1971; "A Propósito de la Mexicaniczacíon de la Empresa Minera Local," El Heraldo de Cananea, September 1, 1971; Gabriel Perales, "México busca consolidar una economía mas indendiente," Avance, August 28, 1971; Luis Echeverría A., "Primer Informe de Gobierno," September 1, 1971. Seis Informes de Gobierno. Estados Unidos Mexicanos: Secretaría de la Presidencia, Direccíon General de Documentación e Informe Presidencial, 1971, September 1, 1971 (http://www.biblioteca.tv/artman2/uploads/1971.pdf), 23; Jesús Morales Tapia, Los Campos Mineros de Cananea (México: Compañía Minera de Cananea, 1985), 88, fn. 3; Information Memorandum, "Compañía Minera de Cananea, S.A.: U.S. $\$ 150,000,000$, Medium Term Loan, October 8, 1979, Archivo General de la Nacion, Archivo Histórico de Nacional Financiera, Operaciones Bancarias Internacionales, Box 610, p. 6-7; "Sección Nacional, Sector Minero, Mexicanización de Compañía Minera de Cananea," Revista Comericioi Exterior, 773. 
enterprises. In 1976, The CFM owned equity shares in 32 companies related to mining. ${ }^{15}$

The Cobre de México, S.A. was established in 1943 for the purpose of refining blister copper and became the first refinery with the capacity for electrolytic processing. This constituted the first major step toward the integration of the copper industry and the satisfaction of domestic industrial needs. This effort toward integration initially failed because the two major producers of copper, including the Cananea Consolidated Copper Company, sent blister copper for refining to the United States. This changed after Anaconda bought a $25 \%$ stake in Cobre de México. Thereafter, Cananea redirected all of its production there for refining and sale..$^{16}$

The main private owner of the CMC was the Banco Nacional de México. Although it only owned $5 \%$ of the company's shares, it wielded a disproportional amount of influence. The oldest private bank in Mexico, Banamex was one of the main institutions that comprised the financial oligarchy based in Mexico City. In the 1970s, it owned shares in more than one hundred companies. Only in twenty of these did it have majority ownership, but its executives wielded vast influence

\footnotetext{
${ }^{15}$ Information Memorandum, "Compañía Minera de Cananea, S.A.: U.S. $\$ 150,000,000$, Medium Term Loan, October 8, 1979, Archivo General de la Nacion, Archivo Histórico de Nacional Financiera, Operaciones Bancarias Internacionales, Box 610, p. 7; "Sección Nacional," Revista Comercio Exterior, February 1976, 154.

${ }^{16}$ Sariego et al., El estado, 177-178; Sariego, Enclaves, 312; Information Memorandum, "Compañía Minera de Cananea, S.A.: U.S. \$150,000,000, Medium Term Loan, October 8, 1979, Archivo General de la Nacion, Archivo Histórico de Nacional Financiera, Operaciones Bancarias Internacionales, Box 610, p. 7, 85; Archivo General de la Nacion, Archivo Histórico de Nacional Financiera, Gerencia de Control de Empresas Filiales, Box 393, Cobre de México, "Cobre de México, S.A. de C.V.: Dividendos al 31 de diciembre de 1986," n.p.
} 
through their membership on the boards of dozens of these companies. ${ }^{17}$ Due to its financial resources and participation in the administration of large industrial, commercial, and service enterprises, Banamex "occupied a hegemonic position in the economic structure as a whole." ${ }^{18}$ It was able to influence both the direction of financial and economic policy, and the appointments to public institutions including the Bank of Mexico and Nacional Financiera. ${ }^{19}$ One outstanding feature of the Banco Nacional de México, is the "strong majority participation of North American transnational enterprises in its capital, its direction, and its financing." 20 The interests of Banamex often aligned with the interests of foreign investors and both shaped the Mexican economy through the efforts of the bank's chairman of the Board of Directors, Agustin F. Legorreta, who also served on the board of directors of the Banco de México and the $\mathrm{CMC}^{21}$

Among Cananea's various owners, Nacional Financiera (NAFINSA) emerged as the most important government institution. It was initially formed in 1934 as part of an effort to construct viable government institutions for the longterm promotion of the country's political stability and economic recovery after the Mexican Revolution and Great Depression. Initially formed as an agrarian bank,

\footnotetext{
${ }^{17}$ Concheiro, El poder de la gran burgesía, 205 207, 218.

${ }^{18}$ Concheiro, El poder de la gran burgesía, 205.

${ }^{19}$ Concheiro, El poder de la gran burgesía, 206-219.

${ }^{20}$ Concheiro, El poder de la gran burgesía, 207.

${ }^{21}$ Concheiro, El poder de la gran burgesía, 229-230.
} 
it was restructured in 1940 to become the primary institution for the financing of industrialization. NAFINSA became the primary intermediary in the negotiation and acquisition of international loans for public and private enterprises in Mexico. ${ }^{22}$ It fostered the development of economic activities with "linkage effects," promoting new and existing firms for the purpose of integrating the industrial process within Mexico. ${ }^{23}$ The acquisition of the CMC more closely integrated the company with properties in which NAFINSA also had possession. In this way, NAFINSA participated in every process associated with copper mining. The $\mathrm{CMC}$ became more closely integrated with Cobre de México, which refined electrolytic copper and sold blister copper to two major manufacturers of copper products, Industrias Nacobre, S.A. and Condumex, S.A. ${ }^{24}$

The board of directors of Nacional Financiera consisted of seven members. Three of these positions were populated by the heads of the Secretaries of the Treasury, National Patrimony, and Industry and Commerce. NAFINSA's president and general manager was a board member of the Bank of Mexico and other corporations in which NAFINSA possessed majority and

\footnotetext{
${ }^{22}$ Morton, 75-76, 81. Sariego, Enclaves, 210-213, 223; Robert T. Aubey, Nacional Financiera and Mexican Industry: A Study of the Financial Relationship Between the Government and the Private Sector of Mexico (Los Angeles: University of California, Los Angeles, 1966), 1, 23; Brian R. Hamnett, A Concise History of Mexico, 2nd ed. (Cambridge: Cambridge University Press, 2006), 233; Calvin Blair, "Nacional Financiera: Entrepreneurship in a Mixed Economy," in Public Policy and Private Enterprise in Mexico, ed. Raymond Vernon (Cambridge, MA: Harvard University Press, 1964), 193-194, 196, 201.

23 Sariego, Enclaves, 226.

24 "Condumex Culminó Su Proceso de Mexicanización," El Informador, July 8, 1974; Information Memorandum, "Compañía Minera de Cananea, S.A.: U.S. \$150,000,000, Medium Term Loan, October 8, 1979, Archivo General de la Nacion, Archivo Histórico de Nacional Financiera, Operaciones Bancarias Internacionales, Box 610, p. 74-75, 79.
} 
minority equity shares in industries related to "finance, manufacturing, mining, petroleum, and public utilities." 25 Ownership by NAFINSA often provided membership to the company's board of directors. In this way, NAFINSA became "a means for protecting a significant creditor or minority-ownership position, or a means for voicing the official interest of the federal government."26 In 1970, Nafinsa possessed equity in 113 companies. ${ }^{27}$ Nafinsa's participation in the economic development in Mexico, made it more influential than any private sector group.

Mexicanization drastically reduced Anaconda's ownership of the CMC, but the change in ownership belied the extent of Anaconda's influence in Mexico. Anaconda retained $49 \%$ of the enterprise through its subsidiary, the Greene Cananea Copper Company, making Anaconda the single largest possessor of equity shares in contrast to the dispersed nature of Mexican holdings. For Anaconda's executives, compliance with the Mexicanization Law emerged as a practical business strategy, promising tax reductions of 50 to $100 \%$ on production, export, import, revenue, and surveying for five years. ${ }^{28}$ Anaconda also possessed significant holdings in complementary firms including Cobre de

\footnotetext{
${ }^{25}$ Blair, “Nacional Financiera," 197-198.

${ }^{26}$ Blair, "Nacional Financiera," 197-198.

${ }^{27}$ Information Memorandum, "Compañía Minera de Cananea, S.A.: U.S. $\$ 150,000,000$, Medium Term Loan, October 8, 1979, Archivo General de la Nacion, Archivo Histórico de Nacional Financiera, Operaciones Bancarias Internacionales, Box 610, p. 67.

28 Incentives for Mexicanization, "A Digest of Mining in Mexico" Arizona Historical Society, n.a., 1968, Arizona Historical Society, Manuscripts Department, MS 1032, Cananea Consolidated Copper Co. Records, 1898-1969, Box 4, Series II, Folder 70, "Company History," p. 1.
} 
México, Industrias Nacobre S.A. (40\%), and Condumex S.A. (23.2\%). By retaining ownership in the $\mathrm{CMC}$ and these associated companies, Anaconda possessed equity in all aspects of copper production in Mexico - extraction, refining, fabrication, and sales. ${ }^{29}$ With Mexicanization, companies like Anaconda persisted as a significant force in the Mexican economy despite losing majority ownership in its many enterprises.

In 1960, Eduardo Bustamente claimed that Mexicanization would integrate mining into the industrialization and economic development of Mexico. After the company's new shareholders received formal control on November 15, 1971, they installed a new board of directors to begin this process. ${ }^{30}$ A number of American managers were demoted and reassigned to new positions. Robert C. Weed, the executive president and general manager of the CMC, became president of the Primary Metals Division of the Anaconda Company. William A. Humphrey, executive vice president and general manager of the $\mathrm{CMC}$, was put in charge of mining and metalurgical operations. ${ }^{31}$ Americans continued to hold director positions. In turn, Mexican officials populated the board of directors of the company. Eduardo López Prieto was elected the company’s first chairman and director general and charged with the responsibilities of executive

\footnotetext{
29 “Condumex Culminó Su Proceso de Mexicanización," El Informador, July 8, 1974; Sariego, Enclaves, 318.

30 "Cananea Tiene Reservas de Cobre Para 200 Años más," El Sol de México, November 16, 1971; "Consejo de Administración Para Cananea," Avance, November 16, 1971; "Formal Mexicanización de la Compañía Minera," El Sonorense, November 16, 1971.

31 J. Rubén Velazco, "Atenta Comunicación, A Nuestro Secretario General, Sr. Héctor Lavander," 1906, October 16, 1971.
} 
president. ${ }^{32}$ In 1960, López Prieto had been the most strident opponent of the Mexicanization law as a defender of foreign interests. Ten years later, he took on the duty "to carry out the integral Mexicanization of the company."33 While serving as the CMC's chairman, López Prieto also held leadership positions on the board of directors of other companies including Condumex, S.A. ${ }^{34}$

Parastate enterprises emerged to assert state control over the industry. Typically, the control and oversight of parastate enterprises extended to three government ministries: the Treasury, the Presidency, and the Secretary of Energy, Mines and Parastate Industry (SEMIP). The CMC should have fallen under the jurisdiction of SEMIP. Instead, Cananea reported its finances to Nacional Financiera in quarterly meetings; operations and management remained independent. Mark Eric Williams writes, "management consistently tried to avoid the attention of central authorities. It chose not to establish a public relations department, rarely issued news briefs, and seldom accepted calls from bureaucrats in Mexico City." 35 And so, the CMC emerged as the most

\footnotetext{
32 J. Rubén Velazco, "Atenta Comunicación, A Nuestro Secretario General, Sr. Héctor Lavander," 1906, October 16, 1971; Pedro Rosales C., "La Mexicanización de la Minera de Cananea ya Quedó Confirmada," Novedades, November 16, 1971; "Malos Mexicanos Apoyan a Empresas Extranjeras," 1906, January 7, 1961.

33 "Formal Mexicanización de la Compañía Minera," El Sonorense, November 16, 1971; Sotero R. Garciasreyes, "El Control de la Minera de Cananea en Manos Mexicanas," El Heraldo de México, November 16, 1971.

34 “Condumex Culminó Su Proceso de Mexicanización," El Informador, July 8, 1974.

${ }^{35}$ Williams, Market Reforms in Mexico, 74.
} 
autonomous of parastate enterprises and operated more like a private enterprise than a publicly-owned one. ${ }^{36}$

After decades of stagnation, Mexicanization brought an infusion of funds into the mining industry. From 1973 to 1988 , the Compañía Minera de Cananea underwent three major expansion and modernization efforts. The first, from 1973 to 1976 , included an investment of 1,800 million pesos in concentration, foundry, and pits to elevate annual production to 70,000 tons of blister copper, at a reported cost of $\$ 118$ million. The second expansion, the "Basic Work Program," lasted from 1977 to 1980 . During this project, expenditures on capital improvements, the repayment of debt, and improvements of machinery sought to increase production to 100,000 tons a year. Total costs eventually reached $\$ 494.1$ million (1,000 million pesos). ${ }^{37}$ At a billion dollars, the third and final expansion project, from 1982 to 1988, became the "largest most expensive public investment program" of the decade. ${ }^{38}$

Still, Mexicanization imposed significant costs on the company, and placed it in debt to several international banks. Taking sovereign control of the company itself, first required the purchase of Anaconda's holdings at a cost of $\$ 24,000,000$, with an additional "liquidating dividend" of $\$ 30,000,000$, which

\footnotetext{
${ }^{36}$ MacLeod, Downsizing the State, 60-61; Williams, Market Reforms in Mexico, 75-76.

37 "Por Primera vez, en los Ultimos 35 Años, se Hizo una Vital Ampliación en Cananea," 1906, October 21, 1976; Sariego, Enclaves, 313. Information Memorandum, "Compañía Minera de Cananea, S.A.: U.S. $\$ 150,000,000$, Medium Term Loan, October 8, 1979, Archivo General de la Nacion, Archivo Histórico de Nacional Financiera, Operaciones Bancarias Internacionales, Box 610, p. 21.

${ }^{38}$ Williams, 76.
} 
forced the company to take a loan from Chase Manhattan Bank and First

National City Bank. After the first expansion, the CMC possessed credit and

loans from Citibank, Chase Manhattan Bank, Bank of America, International

Mexican Bank, Arizona Bank, Chemical Bank International of Chicago, Nacional

Financiera, and Banamex. The second expansion was funded by the American

Express Bank, Dresdner Bank, A.G., Bank of Montreal, Citicorp International

Group, and Continental Illinois Limited. ${ }^{39}$ Funding for the third expansion was

mediated by the Secretary of Treasury and NAFINSA for financing and

machinery. By 1987, the CMC held loans with at least fourteen foreign banks

and three domestic banks. ${ }^{40}$

\footnotetext{
39 Information Memorandum, "Compañía Minera de Cananea, S.A.: U.S. $\$ 150,000,000$, Medium Term Loan, October 8, 1979, Archivo General de la Nacion, Archivo Histórico de Nacional Financiera, Operaciones Bancarias Internacionales, Box 610, p. 1, 3, 4, 6, 127.

${ }^{40}$ Morton, 82-83; Archivo General de la Nación, Fondo: Secretaria de Hacienda y Crédito Público, Direccion General de Credito, Alfabético, N, NAFINSA, Box 205, Exp. 2 (September 23, 1981), September 23, 1981; Archivo General de la Nación, Fondo: Secretaria de Hacienda y Crédito Público, Direccion General de Credito, Alfabético, N, NAFINSA, Box 205, Exp. 2 (September 23, 1981), December 31, 1981; Archivo General de la Nación, Fondo: Secretaria de Hacienda y Crédito Público, Direccion General de Credito, Alfabético, N, NAFINSA, Box 206, Exp. 1 (January 29, 1982), January 29, 1982; Archivo General de la Nación, Fondo: Secretaria de Hacienda y Crédito Público, Direccion General de Credito, Alfabético, N, NAFINSA, Box 206, Exp. 62 (May 4, 1982), May 4, 1982; Archivo General de la Nación, Fondo: Secretaria de Hacienda y Crédito Público, Direccion General de Credito, Alfabético, N, NAFINSA, Box 206, Exp. 62 (May 4, 1982), May 17, 1982; Archivo General de la Nación, Fondo: Secretaria de Hacienda y Crédito Público, Direccion General de Credito, Alfabético, N, NAFINSA, Box 208, Exp. 4 (December 7, 1982), December 7, 1982; Archivo General de la Nación, Fondo: Secretaria de Hacienda y Crédito Público, Direccion General de Credito, Alfabético, N, NAFINSA, Box 206, Exp. 62. (May 4, 1982) May 10, 1982; Archivo General de la Nación, Fondo: Secretaria de Hacienda y Crédito Público, Direccion General de Credito, Alfabético, N, NAFINSA, Box 207, Exp. 72 (September 29, 1982), September 20, 1982; Compañía Minera de Cananea, "Junto Consejo de Administración," November 16, 1987, Archivo General de la Nacion, Archivo Histórico de Nacional Financiera, Dirección General, Box 1, n.p; Compañía Minera de Cananea, "Comentarios previos a la sesión de Consejo de Administración que se celebrará el día 26 de agosto de 1987," Archivo General de la Nacion, Archivo Histórico de Nacional Financiera, Dirección General;Compañía Minera de Cananea, "Junto Consejo de Administración," November 16, 1987, Archivo General de la Nacion, Archivo Histórico de Nacional Financiera, Dirección General, Box 1, n.p.
} 
Mexicanization represented, at least in theory, the strongest assertion of national sovereignty over the nation's mineral resources. José Campillo Saínz, sub-secretary of Industry and Commerce, claimed that the policy of Mexicanization had increased the participation of Mexican capital in the mining industry. ${ }^{41}$ The establishment of majority control by Mexican nationals, however, did not forbid the involvement of foreign capital. Mexico relied heavily on external sources of funding, technology, and sales. So, although foreign investors seemed to have lost control of the company after the change in ownership, they continued to exert control over the mining industry, creating new forms of dependency that were more effective and subtler. ${ }^{42}$ Mexicanization thus provided more the rhetoric of nationalist control more than its reality.

\section{Workers' Experience}

After the Mexicanization of the Compañía Minera de Cananea, workers expected national control of resources to bring greater control of their economic and working lives. As these promises gave way to a harsher reality, government discourses justified these realities in a number of ways. First, the success of Mexicanization was measured by economic indicators, such as productivity and efficiency rather than the well-being of workers. Second, the complaints of workers were met by appeals to the national interest, and told to sacrifice

\footnotetext{
41 “Tesis de México Sobre Inversiones Extranjeras," El Nacional, October 15, 1972.

42 Sareigo, Enclaves, 305.
} 
themselves for the national interest, for deferred gains. For the economic wellbeing of the nation, workers were to inhabit a passive and subservient role within the Mexican economy. The health of the company and the national economy increasingly stood in for the social well-being of the workers.

The acquisition of the $\mathrm{CMC}$ allegedly completed the recovery of the country's national sovereignty, and expectations for the mining industry and for copper mining soared. The infusion of state support in material and financial terms generated enthusiasm and optimism among many sectors of Mexican society. State intervention became critical in the revival of the mining industry, channeling funds into the mining industry and fueling multiple expansion projects. The infusion of funding helped to revive defunct companies, provide employment, and strengthen industrial stability, which in turn increased investments. The state promoted the rational use of natural resources and controlled prices for the benefit of domestic producers. In turn, these investments strengthened the mining industry making it a sounder proposal for investments from private sources. The Mexicanization of Cananea also eliminated a key obstacle to industrial development by providing a steady supply of copper to the electrical and metalworking industries, two of the nation's most productive industries since their formation in the 1940s. ${ }^{43}$

\footnotetext{
43 "No más "Manos Muertas" en la Minería," El Nacional, October 4, 1975; Luis Echeverría A., "Tercer Informe de Gobierno," September 1, 1975, Seis Informes de Gobierno. Estados Unidos Mexicanos: Secretaría de la Presidencia, Direccíon General de Documentación e Informe Presidencial, 1975, September 1, 1975 (http://www.biblioteca.tv/artman2/uploads/1975.pdf), 145.
} 
National control of the mining industry promised economic gain. On the eve of Cananea's Mexicanization, Echeverría announced a total of 58 million tons of copper in reserve. Annual production by it sat at 42,000 tons annually, and the company produced $60 \%$ of the nation's copper supply. In 1972, President Echeverría announced an investment of 8 billion pesos to fund fourteen projects with the goal of doubling the total production of the mining industry. Cananea received nearly a tenth of this amount. Its first expansion began with an initial investment of 93 million pesos and eventually reached a total of 750 million pesos. In its first year as a Mexicanized company, Cananea achieved records in production, sales, and revenue. Horacio Flores de la Peña, Secretary of National Patrimony, announced "sales of 635 millones de pesos, representing an income $36 \%$ above the previous year, generating a net profit. . of 91 millon 500 thousand pesos $(91,500,000) .{ }^{44}$ Governor Alejandro Carrillo Marcor announced that Sonora was poised to become the primary mining state in the country and transform Mexico into "one of the largest producers of copper in the world." ${ }^{45}$ At the conclusion of Cananea's first expansion in 1976, President Echeverría claimed that copper reserves reached 1,600 million tons and would guarantee a supply of the metal for more than a hundred years. Annual

\footnotetext{
44 "Nivel Record de Ingresos y Ventas en la Mina Cananea, Según Informó la ANACONDA," El Nacional, March 28, 1973; "Ha Florecido la Minera de Cananea, hoy Mexicanizada," El Informador, February 23, 1973; Luis Echeverría A., "Segundo Informe de Gobierno," September 1, 1972. Seis Informes de Gobierno. Estados Unidos Mexicanos: Secretaría de la Presidencia, Direccíon General de Documentación e Informe Presidencial, 1972, September 1, 1972, (http://www.biblioteca.tv/artman2/uploads/1972.pdf), 38.

45 "México Pudiera Llegar a Gran Productor de Cobre," El Informador, January 3, 1977; "Reservas de Cobre Aseguradas Para los Próximos 200 años," El Informador, October 21, 1976.
} 
production increased to 75,000 tons a year, representing $80 \%$ of the nation's copper output. ${ }^{46}$

Supporters of Mexicanization claimed that participation with foreign capital strengthened national sovereignty. Workers recognized that Anaconda and other firms associated with the Compañía Minera de Cananea derived numerous advantages from Mexicanization. ${ }^{47}$ These included easier access to financing, tax reductions, access to "a captive market, access to technology, and easy repatriation of its capital, in addition to the use of cheap inputs." ${ }^{38}$ This differed sharply from the nationalization of the oil industry by Cárdenas, which had entirely excluded foreign participation in that sector, leading to a boycott, and causing significant economic and political crises. With respect to Mexicanization, claims of sovereign control of mineral resources rested solely on the basis of majority ownership in mining firms. With the $\mathrm{CMC}$, one foreign company owned

\footnotetext{
46 "Sección Nacional, Sector Minero," Revista Comericioi Exterior (September 1971), 773; "Texto de 2do. Informe-Echeverría Sobre la Mexicanización Minera," 1906, September 30, 1972; Luis Echeverría A., "Segundo Informe de Gobierno," September 1, 1972. Seis Informes de Gobierno. Estados Unidos Mexicanos: Secretaría de la Presidencia, Direccíon General de Documentación e Informe Presidencial, 1972, September 1, 1972, (http://www.biblioteca.tv/artman2/uploads/1972.pdf), 48; "Inversiones por Ocho mil Millones de Pesos Para Lograr la Expansión de la Minería Mexicanziada," El Nacional, June 28, 1973; Octavio Raziel, "Promisorio Futuro Para Sonora con el Descubrimiento de Ricas Vetas de Cobre," El Nacional, December 16, 1976; "Actividades Primarias, Los Problemas de la Minería," Revista Comercio Exterior (May 1973): 416; "Reservas de Cobre Aseguradas Para los Próximos 200 años," El Informador, October 21, 1976; "En Cananea, la Extracción de Cobre Aumentó en 75 mil Toneladas al Año," El Nacional, October 21, 1976 ; Luis Echeverría A., "Primer Informe de Gobierno," September 1, 1971. Seis Informes de Gobierno. Estados Unidos Mexicanos:

Secretaría de la Presidencia, Direccíon General de Documentación e Informe Presidencial, 1971, September 1, 1971 (http://www.biblioteca.tv/artman2/uploads/1971.pdf), 22.

47 “Un Marco de Referencia Necesario," 1906, September 24, 1983.

48 "Se Requiere Importar Minerales que la Producción no Proporciona" "Minería, Alternativa Para la Crisis," El Nacional, August 3, 1983.
} 
nearly half of the company; over four different entities comprised the Mexican portion. Claims of national control thus appeared weak.

Mexicanization achieved economic independence through the participation of foreign investors but on terms beneficial to Mexico. As in the colonial and Porfirian eras, foreign investment was seen as critical to the economic development of Mexico. Juan Guillermo Becker Arreloa, a sub-director of the Secretary of Industry and Commerce, argued that true economic independence required foreign participation, but not in its traditional role as an imperialist. With Mexicanization, the CMC was "no longer a company serving transnationals."49 Instead, foreign investors were expected to work in cooperation with Mexican firms in order to advance Mexican interests. According to an article in El Nacional, success had already been achieved:

The association of national and foreign capital has produced better knowledge and mutual respect and has permitted to combine the techniques of the companies coming from the exterior with the knowledge of the market, of the laws, the uses, the customs and traditions of the Mexican people. ${ }^{50}$

The earning of profits remained a legitimate pursuit, but foreign investors were expected to associate with Mexican companies on a minority basis, promote the

\footnotetext{
49 "Se Duplicó en el Sexenio de Echeverría la Producción Minera de Nuestra País," El Nacional, October 21, 1976.

50 “Tesis de México Sobre Inversiones Extranjeras," El Nacional, October 15, 1972.
} 
hiring and training of Mexican nationals, and comply with the laws that protected national sovereignty. ${ }^{51}$

President Echeverría presented foreign investment as a complement to revolutionary nationalism. His efforts were praised for advancing the national interest and implementing durable policies meant to bring lasting change. And for this, he was celebrated as one of the country's most revolutionary presidents, following Lázaro Cárdenas and Adolfo López Mateos. ${ }^{52}$ One writer in El Nacional argued that Cananea demonstrated Echeverría's political shrewdness and pragmatism, by preserving foreign investments while expanding national sovereignty. These policies, he contended, "are complementary and represented a common expression: revolutionary nationalism." ${ }^{\text {33 }}$

The nationalization of Lázaro Cárdenas fundamentally linked national sovereignty to a combined economic and social development. This economic philosophy faded during the presidency of Miguel Alemán but reemerged with Luis Echeverría. According to the President of the Congress of Labor and Senator Carlos Jonguitud Barrios, the emphasis on economic growth as a prerequisite to social justice always deferred the latter into the unreachable future and preempted the social promises of the Mexican Revolution. This was not just

\footnotetext{
51 "La Inversión Nacional, la Inversión Extranjera y la Independencia Económica," El Nacional, February 11, 1973; "Tesis de México Sobre Inversiones Extranjeras," El Nacional, October 15, 1972; Luis Cordova, "Defensa de Nuestra Independencia," El Nacional, January 6, 1973.

52 "10 Millones de Trabajadores Rendirán Homenaje a Echeverría, el $1^{\circ}$ de Mayo," El Nacional, April, 19, 1976; "Más de 5 Millones de Trabajadores Hicieron un Reconocimiento a la Labor de Echevrría," El Nacional, November 28, 1976.

53 "Palabra Cumplida (Cananea)," El Nacional, October 21, 1976.
} 
an idealistic matter, but also a practical one. Wealth without equitable distribution, he contended, created the "germ of violence." ${ }^{54}$ State intervention, as many recognized, had been essential to the growth and success of the private sector in the industry. While President Echeverría expressed the need for a strong entrepreneurial class, he insisted it be tempered by social considerations: "We need a business class, but modern, nationalist, without a colonial mentality, one that feels it must be truly creative, in the construction of a country." ${ }^{\prime 5} \mathrm{~A}$ company's success, he argued, had to be measured not only by its financial success but also by its social ones..$^{56}$

For workers, the achievement of national sovereignty and economic independence offered promises of improved financial security. Workers thought that Cananea's historical legacy and its economic significance would bring them and their city prosperity and greater control over their lives: "We thought. . . it would be our city that would benefit the most, but we see with sadness that, unfortunately, this is not the case." ${ }^{27}$ Five years since the change in ownership,

\footnotetext{
54 "Más de 5 Millones de Trabajadores Hicieron un Reconocimiento a la Labor de Echeverría," El Nacional, November 28, 1976.

${ }^{55}$ Luis Echeverría A., "Segundo Informe de Gobierno," September 1, 1972. Seis Informes de Gobierno. Estados Unidos Mexicanos: Secretaría de la Presidencia, Direccíon General de Documentación e Informe Presidencial, 1972, September 1, 1972, (http://www.biblioteca.tv/artman2/uploads/1972.pdf), 67.

${ }^{56}$ Luis Echeverría A., "Tercer Informe de Gobierno," September 1, 1975. Seis Informes de Gobierno. Estados Unidos Mexicanos: Secretaría de la Presidencia, Direccíon General de Documentación e Informe Presidencial, 1975, September 1, 1975 (http://www.biblioteca.tv/artman2/uploads/1975.pdf), 145.

57 “Graves Problemas que Debe Acelerar Cía Minera," 1906, March 5, 1983.
} 
Luis Bojórquez pointed out that there had been no improvements for workers who continued to endure the same burdens and mistreatment they had experienced under foreign ownership. ${ }^{58}$ The most optimistic assessment claimed that the company's managers and administrators were negligent. ${ }^{59}$ More often, poor treatment and labor abuses were considered deliberate and purposeful: "their mentality was and keeps being in the majority of cases, a systematic behavior against the worker." ${ }^{\circ 0}$ The company's transition from foreign ownership to majority Mexican ownership failed to manifest goodwill toward Mexican workers. ${ }^{61}$

The sale of ownership shares in the company promised worker participation in the company. In August 1972, national and regional newspapers announced the sale of 180,000 shares, or $3 \%$ of the company's total shares, at 100 pesos each. Eduardo Prieto López, the company's director, indicated that workers would be able to purchase shares worth up to three months' salary, payable over five years in monthly installments. These transactions were to be conducted on the basis of individual contracts maintained by a trust managed by Banco Nacional de México. These efforts toward "the democratization of capital.

\footnotetext{
${ }^{58}$ Luis Bojórquez, “¿Cómo Actuar?,” 1906, March 5, 1977.

59 “Graves Problemas que Debe Acelerar Cía Minera," 1906, March 5, 1983.

${ }^{60}$ Luis Bojórquez, “¿Cómo Actuar?,” 1906, March 5, 1977.

61 M.M., "La Sección 65 en Justa Lucha Contra Cía Minera," 1906, January 3, 1981; Reglamento Interior y Reglamento de Seguridad e Higiene Industrial; e incluso marullerias para querer controlar el Sindicato y seguir oprimiendo al trabajador;" "Cía. Minera se Vista de Piel de Oveja," 1906, December 13, 1980.
} 
. . exclusively among Mexican investors" were celebrated as a remarkable achievement. ${ }^{62}$ Workers were esteemed as participants in the company's ownership, control, management, and benefits equivalent to those of the company's private and public owners. ${ }^{63}$ The rhetoric of ownership and participation, however, failed to match its reality.

The possibility of owning the company ultimately generated more skepticism among workers than confidence. Writers in the union weekly pointed out discrepancies in the number of shares for purchase: In a 1971 article President Echeverría had indicated that $5.88 \%$ of the total shares would be available to workers, while former executive president and general manager Robert C. Weed claimed that this figure stood closer to $3 \% .{ }^{64}$ Further confusing the situation, Echeverría claimed that this total reached as high as $8 \%$ in $1976 .{ }^{65}$ In all cases, the number of shares available to workers comprised a small

62 "Venta de Acciones Sólo a Inversionistas Mexicanos," El Informador, August 9, 1972; "A Disposición de los Inversionistas Mexicanos 720 mil Acciones de la Cía. Minera de Cananea," El Nacional, August 9, 1972; Young Coral, "A Disposición de los Inversionistas Mexicanos 720 mil Acciones de la Cía. Minera de Cananea," El Nacional, August 9, 1972.

${ }^{63}$ Eduardo Prieto López, "Carta Circular, A: Los Empleados y Trabajadores Mexicanos de la Compañía Minera de Cananea S.A., De: La Dirección General, Re: VENTA DE ACCIONES," 1906, December 18, 1971; Eduardo Prieto López, "Carta Circular, A: Los Empleados y Trabajadores Mexicanos de la Compañía Minera de Cananea S.A., De: La Dirección General, Re: VENTA DE ACCIONES," 1906, December 25, 1971; "\$200.00 Diarios Ganan los Mineros en Cananea," El Informador, June 28, 1973; Compañía Minera de Cananea, "Obras de Ampliación, 1973-1976," 1976, 2; "Por Primera vez, en los Ultimos 35 Años, se Hizo una Vital Ampliación en Cananea," 1906, October 21, 1976.

64 "Cananea es una Explotación Minera que está Ligada Intimamente a la Historia de la Revolución Mexican y el Movimiento Obrero del País," 1906, October 2, 1971; Pedro Reyes Zuñiga, Srio. General de Trabajo, letter, "Comunicación del Comité Ejecutivo General a la Sría. Loc. del Trabajo," 1906, November 20, 1971.

65 "Se Duplicó en el Sexenio de Echeverría la Producción Minera de Nuestra País," El Nacional, October 21, 1976. 
fraction of the company's ownership, vastly outmatched by the preponderance of government and private capital, nullifying any power the workers might gain through their participation. ${ }^{66}$ The possibility of ownership masqueraded as participation, yet real participation was negated by the small proportion of shares made available to workers and the limited financial resources of workers to buy them. Pedro Reyes Zuñiga, Secretary General de Trabajo from the national mining union, suggested that the sale of shares obscured the reality of management failures and worsening labor conditions. ${ }^{67}$

The most promising economic benefit afforded by Mexicanization was employee profit sharing. Yet, almost as soon as it began, the company ended the program in 1975 and it quickly became a source of recurring grievance. Company managers and executives justified the change as necessary to recover the costs of depreciating machinery used by workers. At first, the government seemed willing to intervene on behalf of the workers. In November 1975, the Finance Minister determined that the company had underreported its earnings and failed to pay 8 million pesos out of a total 39 million pesos and determined that $\$ 5000$ pesos should be distributed to each worker. Two years later this ruling was reversed, and the company received an official deferral in $1980 .{ }^{68}$

\footnotetext{
${ }^{66}$ Pedro Reyes Zuñiga, Srio. General de Trabajo, letter, "Comunicación del Comité Ejecutivo General a la Sría. Loc. del Trabajo," 1906, November 20, 1971.

${ }^{67}$ Pedro Reyes Zuñiga, Srio. General de Trabajo, letter, "Comunicación del Comité Ejecutivo General a la Sría. Loc. del Trabajo,” 1906, November 20, 1971.

68 "Como 8 Millones de Pesos, Utilidades del Año 74 Pagarán a los Obreros," 1906. April 23, 1977; "Los Mineros Reclaman el Reparto de Utilidades," 1906, March 12, 1977; "La Maquinación de "Cerebros de la Empresa,"” 1906, March 19, 1977.
} 
Less than ten years after the acquisition of Cananea, employee profit sharing had "become a myth."69

Workers expected national sovereignty to improve financial security, but instead, they suffered from indirect forms of exploitation. Wages were reduced through inflation, taxes, and the high cost of living. Workers complained of an unjustified increase in 1978 in the cost of essential goods which registered an increase between $30 \%$ to $40 \%{ }^{70}$ Five years later, prices jumped by $300 \%$, reducing real wages and producing economic hardship and a strike in $1983 .{ }^{71}$ Wages were further reduced through excessive taxation. When tax withholdings should have been closer to "200 or 300 pesos for the year," the companies had levied ten times the amount. ${ }^{72}$ These cuts were not a loss of luxury goods, but constituted an existential harm perpetrated on workers and the well-being of their families. Contrary to claims that workers were greedy, the workers were concerned about survival. "We ask to live," pleaded one writer. ${ }^{73}$ Jorge Acedo Samaniego, leader of Section 65, described the threat posed by taxes as a

\footnotetext{
69 "Un Mito el Reparto de Utilidades; Las Empresas Defraudan a Obreros y Fisco," 1906, July 28, 1979.

70 "30\% Aumentaron los Precios en Cananea sin Justificación," 1906, March 4, 1978.

71 "Estalló el Movimiento de Huelga en Contra de Cía. Minera," 1906, September 24, 1983; Informe, Secretaria de Gobernación, Dirección General de Investigaciones Políticas y Sociales, "Estalla la Huelga en la Compañía Minera de Cananea," Archivo General de la Nación, Secretaria de Gobernación, Dirección General de Investigaciones Políticas y Sociales, Box 1661A, Exp. 4, September 5-20, 1983. September 5, 1983.

72 "Impuestos, Fraude y Otras Cosas," 1906, February 2, 1980; "El Abuso de Impuestos Federales nos Arruina," 1906, December 6, 1980.

73 “¡Alto a los Impuestos! ¡Dejenos Vivir!,” 1906, January 26, 1980.
} 
"genocide that is being committed against our economy."74 The national sovereignty won by Mexicanization was that of national interests defined by the government bureaucracy and private capital. Rather than advancing its own interests, labor remained subservient to those of the nation.

Workers expected national control of resources to give them greater control of work processes. President Echeverría claimed, "[t]he patrimony of man and society is work." 75 Work as national patrimony, then, became something inalienable and intrinsic, suggesting that it had more than pecurinary value for the worker. Many expressed gratitude that nature had provided subsistence to generations of workers and were proud to work the mines they considered their heritage ${ }^{76}$ They regarded the mines as an economic resource that needed to be developed and exploited for the benefit of the community. ${ }^{77}$ One editorialist contested the notion of productivity as a purely accumulative concept. He defined productivity "as a means to reconcile the requirements of growth with those of social development, and it is evident that the latter is an indispensable condition for obtaining a significant increase simultaneously with the achievement of greater social welfare."78 Efficency was defined as the use of

\footnotetext{
74 “Discurso por el Co. Jorge Acedo-Srio. General Loc.," 1906, June 3, 1978.

${ }^{75}$ Luis Echeverría A., "Tercer Informe de Gobierno," September 1, 1975. Seis Informes de Gobierno. Estados Unidos Mexicanos: Secretaría de la Presidencia, Direccíon General de Documentación e Informe Presidencial, 1973, September 1, 1975 (http://www.biblioteca.tv/artman2/uploads/1975.pdf), 132.

76 “Cananea Cuna de la Revolución Mexicana," 1906, January 19, 1980.

77 “Cananea Cuna de la Revolución Mexicana," 1906, January 19, 1980.

78 “Definición de Productividad," 1906, April 15, 1978.
} 
"available resources to produce social wealth."79 The purpose of economic development was not the accumulation of goods but the human capacity to improve "the existence and development of man in all its manifestations of civilization and culture and affection for the ends of a society balanced in justice, freedom, and law." 80 The exploitation of natural resources conveyed meanings beyond purely economic purposes.

The mine workers in Cananea regarded themselves as having more knowledge about their work than the experts employed by the company. Managers and engineers were known as "cerebros" or "sabios" and considered unparalleled in their knowledge and unchallengeable in their authority. ${ }^{81}$ Yet, according to one writer in 1906, workers were the true experts of Cananea's mining operations. He argued that Mexicanization was supposed to have led to greater control of work and the workplace, allowing skilled and knowledgeable workers to actualize their know-how and experience. Such workers often found ways to improve productivity and safety in ways that education could not provide. One article relates how the death of a driller in the 1950s had resulted in new regulations and rules limiting work on slopes after heavy rains. After Mexicanization, the single-minded focus on productivity and production led to the

\footnotetext{
79 “Definición de Productividad," 1906, April 15, 1978.

80 "Más de 5 Millones de Trabajadores Hicieron un Reconocimiento a la Labor de Echeverría," El Nacional, November 28, 1976.

81 “La Maquinación de "Cerebros de la Empresa,"” 1906, March 19, 1977.
} 
quick replacement of workers, eliminating the voices of experience, leading to circumstances in which the machines and the bodies of men were pushed beyond repair. Although workers received most of the blame for the company's problems, the malfeasance of managers was often the true source of the company's problems. ${ }^{82}$

Veteran mine workers blamed the managers and employees hired by the company as incompetent. The writers of 1906 mocked the expertise of engineers and technicians who asserted their authority but lacked experience and learned knowledge. They blamed them for the breakdown of machinery that generated losses in the millions of pesos and often wrongfully attributed to workers. In 1981, ten years after the Mexicanization of the CMC, the only measurable accomplishment of those experts had been the "gradual indebtedness" of the company. In 1985, administrators and managers were characterized as provocateurs who enjoyed exacerbating labor relations. Cases of mistreatment and labor abuses against confidential employees, engineers, and managers rarely led to punishment. The penalties they suffered were light and sometimes led to reassignment but never resulted in firing. Instead, blame was often attributed to workers for the faults of their superiors. ${ }^{83}$

\footnotetext{
82 "Por el Tajo a Cielo Abierto," 1906, October 9, 1971; “De Mal en Peor la Concentradora," 1906, January 30, 1982.

83 "La Sección 65 Una Vez Más Frente a Cía. Minera de Cananea," 1906, January 17, 1981; "¿Obligación de Quién?" 1906, September 3, 1983; "Lucharemos por la Supervivencia de Cananea," 1906, December 3, 1977; “¿Qué Está Sucediendo en Compañía Minera?” 1906, February 13, 1982. "Cía. Minera se Vista de Piel de Oveja," 1906, December 13, 1980; "La Realidad de la Adminstración de Cía. Minera," 1906, March 20, 1982; "Mala Administración en Perjuicio de los Obreros," 1906, March 2, 1985; "Graves Problemas que Debe Acelerar Cía Minera," 1906, March 5, 1983.
} 
Instead of a participatory role, Mexicanization ascribed to mine workers an indirect and passive one. Echeverría celebrated labor's accomplishments in his annual address of 1973: "The workers movement has contributed vigorously to the growth of the economy, to the nationalization of our natural resources and to the achievements in social justice. Without their combative action the contemporary institutions of Mexico would be inexplicable." 84 Workers were still to participate in the economic development of the country but now they would participate indirectly "through their parastate enterprises." 85 Workers would contribute to the economic development of Mexico through their employment and productivity. State control of mineral resources increased funding for expansion and modernization projects but also helped to stabilize wages and increase employment. By expanding employment, more Mexicans would contribute "to the accelerated development of the country." ${ }^{\prime 86}$ In this way, workers affirmed their patriotism in the task of realizing the promises of Mexicanization and consummating the Mexican Revolution. ${ }^{87}$

\footnotetext{
${ }^{84}$ Luis Echeverría A., "Tercer Informe de Gobierno," September 1, 1973. Seis Informes de Gobierno. Estados Unidos Mexicanos: Secretaría de la Presidencia, Direccíon General de Documentación e Informe Presidencial, 1973, September 1, 1973 (http://www.biblioteca.tv/artman2/uploads/1973.pdf), 75.

${ }^{85}$ Luis Echeverría A., "Primer Informe de Gobierno," September 1, 1971. Seis Informes de Gobierno. Estados Unidos Mexicanos: Secretaría de la Presidencia, Direccíon General de Documentación e Informe Presidencial, 1971, September 1, 1971 (http://www.biblioteca.tv/artman2/uploads/1971.pdf), 23.

${ }^{86}$ Luis E. Cárdenas, "Se han hecho Inversiones en Varias Ramas, Contra el Desempleo: Flores de la Peña," El Nacional, November 16, 1971.

87 "La Minería es la más Propicia Actividad Contra el Desempleo," El Nacional, June 28, 1973; Guillermo Pacheco, "El Programa de Mexicanización de la Minería se Halla en su Fase Final, Dijo Francisco Javier Alejo," El Nacional, March 12, 1975; "Voz Que Desentona," 1906,
} 
Mine workers from Cananea, in particular, were relegated to a subordinate position within the company. This became apparent in the use of confidential employees. These non-unionized employees provided a flexible portion of the work force and were often used to bypass and weaken the collective contract. Some confidential employees started out in menial jobs and justified their hiring by arguing that their employment did not reduce opportunities available to unionized workers. But in some cases, they demanded the company pay them according to the wage and promotion scale of the unionized workers. Others took positions for which they were unqualified and were promoted despite their low experience or ability. In doing so, they usurped "The right of seniority and promtion [that] are the exclusive property of workers." ${ }^{88}$ These employees failed to appreciate the contributions of labor to their own livelihood and harmed the prospects of the entire workforce by eschewing union representation. ${ }^{89}$ In several cases, confidential employees emerged as the direct antagonists of unionized workers. Some were accused of undermining morale by acting as spies and spreading rumors about mine closures, personnel, and hour reductions. Many were hired outside of Cananea and Mexico; from Chile, Argentina, Spain, and were placed in positions of authority and management, like

September 23, 1972; "Primer Aniversario de la Mexicanización de la Cía. Minera de Cananea," 1906, August 26, 1972.

88 "The right to seniority and promotion that is the workers' exclusive property." See "Con Látigo en Mano Regresa Gaucho' Gallegos a Cia. Minera," 1906, October 14, 1978.

89 “¿Porqué Razón Cía. Minera, no Hace Caso?," 1906, December 8, 1979; "Por los Departamentos Fundición: Pésima Organización," 1906, August 20, 1983; "Con Látigo en Mano Regresa Gaucho' Gallegos a Cia. Minera," 1906, October 14, 1978. 
Juan Gallegos F. from Argentina who was accused of treating workers like slaves. It was claimed that workers hired outside of Cananea were more likely to treat workers harshly. Meanwhile, workers from Cananea were denied the opportunity to reach management positions and were "condemned to serve. . . only as day laborers." ${ }^{90}$ The administration routinely cited fiscal problems to deny promotions and benefits. Meanwhile, outsiders were hired for jobs for which they were unqualified and paid exorbitantly; managers were seen driving new cars and taking vacations. Company administrators also sought to divide workers and prevent their unification against company interests. In one instance, the company refused to disburse housing loans of 110-million-pesos a year provided for by the collective contract. Instead, the company constructed houses and gave them to confidential workers in an effort that gained the support of the state governor and Cananea's municipal president but undermined the union's strength and authority as a representative and advocate for workers. ${ }^{91}$

The success of Mexicanization was increasingly determined not by its ability to advance the well-being of the company's workers but on its economic production. The details of the first expansion were published in "Obras de Ampliación, 1973-1976," a document produced by company management. This pamphlet emphasized and celebrated the positive contributions of the expansión

\footnotetext{
90 “Cía. Minera: ¿Paraestatal?, Si..” 1906, May 23, 1981.

91 "Queremos Realidades Positivas, no Demagogia," 1906, August 28, 1982; “¿Porqué Tiene Que Venir Gente de Fuera?" 1906, August 15, 1981; "Con Látigo en Mano Regresa Gaucho' Gallegos a Cia. Minera," 1906, October 14, 1978; "Cía. Minera: ¿Paraestatal?, Si.." 1906, May 23, 1981; "Por el Tajo a Cielo Abierto," 1906, October 9, 1971; "Primero Somos Nosotros, Señores de la Minera," 1906, February 11, 1984.
} 
project, stressing the integration of the company. Expansion would also strengthen Cananea's integration into the domestic economy, by increasing the availability of copper supplies for complementary industries. It would double mining production by exploiting existing copper reserves, newly discovered veins, and undiscovered sources of copper. The pamphlet detailed the improvements made to facilities, processes, and infrastructure, and they improved the rational use of mineral resources. ${ }^{92}$ The document described the changes as "a collective effort of technicians, workers and officials," ${ }^{\text {"93 }}$ which produced "a multiplying effect on jobs, goods, and services."94 It claimed as well that Mexicanization "had substantially improved the salaries and benefits of its workers" who enjoyed a higher standard of living indicated by rising ownership of homes, automobiles, and household goods such as refrigerators and freezers. ${ }^{95}$ Finally, the pamphlet emphasized the general improvements made to the Compañía Minera de Cananea, while white-washing the long, contentious history of the mines.

The government heralded the increases of productivity and production, but these had different implications for workers. First of all, apparently there truly was no accompanying increase in workers' livelihoods. Articles in the union

\footnotetext{
${ }^{92}$ Compañía Minera de Cananea, “Obras de Ampliación, 1973-1976," 1976, 2-3, 5, 7, 14.

93 Compañía Minera de Cananea, “Obras de Ampliación, 1973-1976," 1976, 1.

${ }_{94}$ Compañía Minera de Cananea, “Obras de Ampliación, 1973-1976,” 1976, 3.

95 Compañía Minera de Cananea, “Obras de Ampliación, 1973-1976,” 1976, 2, 16.
} 
weekly demonstrated that workers possessed their own meanings about the nature of Mexicanization. They argued that Mexicanization was not equivalent to the increase of productivity if it meant the intensification of work at the cost of workers' health. ${ }^{96}$ Workers had previously expressed their willingness to work hard, out of a sense of patriotism and desire to advance the national interests of Mexico. But this did not mean slavish compliance nor the sacrifice of their lives and health, and they insisted on being treated with respect and dignity. Workers scoffed at the campaign initiated by the company which distributed brochures on the recent expansion and modernization efforts. While the pamphlet described the changes as beneficial to the company, miners themselves argued that "for the benefit of the worker there will be nothing." ${ }^{\prime 7}$

New machinery increased worker productivity but it also changed the nature of work. The introduction of new machinery and updated technology transformed workers from skilled, autonomous laborers into unskilled, passive, and interchangeable workers. As technicians, workers felt they were losing control of their work as management failed to recognize them as human beings rather than as interchangeable cogs. Managers were more concerned about production, ignoring requests for maintenance and repairs which led to the degradation of machinery and the deterioration of workers' health, causing

\footnotetext{
96 "Por el Tajo a Cielo Abierto," 1906, October 9, 1971.

97 "Comentarios de Aquí y de de Allá," 1906, March 12, 1977.
} 
injuries and death, with repercussions beyond the individual, putting the livelihoods of entire families in jeopardy. ${ }^{98}$

Before 1971, workers had viewed Mexicanization as a potential solution to the problems created by the automation of mining processes. Instead, consequences such as the loss of employment persisted as government officials touted the increase of production for domestic industry. Workers remained wary that new technology and machinery would create unemployment. ${ }^{99}$ The changes that improved production were good for the company, national development, and domestic industrialization efforts, but harmful to individual workers. Workers rejected such progress if it came at the cost of "hunger and desolation." 100

Mexicanization also failed to decrease the occurrence of illness and death. Despite millions invested in modernization, the company had failed to modernize hygiene and safety measures and reduce the presence of incompetent doctors. Company doctors were often the final arbiter in determining indemnities for workers who had been injured or suffered death. Workers continued to suffer from silicosis and other lung ailments which effectively eliminated any wage increase and all manner of job security. The companies were unable to

\footnotetext{
98 "Lucharemos por la Supervivencia de Cananea," 1906, December 3, 1977; "Por el Tajo a Cielo Abierto," 1906, October 9, 1971; "Co. Minera de Cananea, S. A...Poco Aprecio a la Vida de Trabajadores," 1906, April 2, 1977; "Cuadruplicar la Producción," 1906, August 5, 1978.

99 "Cananea es una Explotación Minera que está Ligada Intimamente a la Historia de la Revolución Mexican y el Movimiento Obrero del País," 1906, October 2, 1971; "Mexicanizaicón más Egoísmo - Desocupación," 1906, July 10, 1971; "Por el Tajo a Cielo Abierto," 1906, October 9, 1971.

100 “Mexicanizaicón - más Egoísmo - Desocupación," 1906, July 10, 1971.
} 
recognize its workers as human beings, lacked concern for their health, and pushed them to the point of sickness and death. Against the hesitation and failures of the company to pay indemnities for disability or death, workers demanded immediate restitution and considered its denial "inhumane" since it not only effected the worker but also his family. ${ }^{101}$ Expansion and increased productivity might be good for the nation, but they could be physically harmful to workers. Genuine and lasting increases in production would mean a safe work space with the necessary equipment available to protect workers. ${ }^{102}$

Unfavorable working conditions were answered by appeals to make sacrifices and hard work. More than a lack of effort, however, the problems faced by workers were those created by managers. In some instances, workers died from "the negligence to take safety measures that truly fulfill the function of minimizing the occupational risks of workers." ${ }^{103}$ Contract violations were the fault of "complacency" by the company's directors, including Emilio Ocampo Arenal, who failed to assume "the minimum responsibility" in the company's

101 “Protesta Contra Cía. Minera por Violar el Contrato," 1906, May 21, 1983.

102 "Falso-Desacierto de un Vocero de Cía. Minera," 1906, June 27, 1981; "Cía. Minera se Vista de Piel de Oveja," 1906, December 13, 1980; "Un Marco de Referencia Necesario," 1906, September 24, 1983; "Cuadruplicar la Producción," 1906, August 5, 1978; "Seres Perfectos Pide la Compañía Minera Local," 1906, April 4, 1981; "Queremos Soluciones No Pretextos," 1906, May 17, 1986.

103 "Cía. Minera se Vista de Piel de Oveja," 1906, December 13, 1980; "Continúan las Pérdidas de Cía. Minera," 1906, August 29, 1981. 
operations. ${ }^{104}$ Workers were expected to keep toiling, even while equipment remained unrepaired. ${ }^{105}$

Instead of gaining control, workers increasingly lost control of working conditions, and they increasingly lost the means to fight back. Mexicanization increased the power of the national mining union but weakened the autonomy of the local chapter in Cananea. After President López Mateos signed Mexicanization into law, the national mining union made efforts to centralize and consolidate its power, becoming more closely aligned with the state. As labor decisions moved from the local to the national level, Section 65 lost much of its autonomy. At the same time, the state increasingly acted as an intermediary for labor because of its new involvement in the mining industry and its new role in the administration of public services. As the company appeared to lose its foreign character, union mobilization diminished. The presence of the state helped suppress, in particular, protest arising from nationalist inspired grievances. The mixed nature of the company's ownership made it difficult to locate a distinct antagonist for workers to protest against. ${ }^{106}$

As Mexicanization failed to realize its promises, workers' allegiance to the Mexican nation began to weaken. As problems persisted, the leaders of Section 65 emphasized Cananea's historical association with the larger narrative of

\footnotetext{
104 "C. Pdte. de la República Lic. Miguel de la Madrid, C Srio. del Trabajo Lic. Farrell Cubillas," 1906, October 27, 1984.

105 "Grave Crisis en Compañía Minera," 1906, August 14, 1982.

${ }^{106}$ Sariego, Enclaves, 372-373, 388, 391-392 (in 1961).
} 
Mexican history. Referring to one of the myths addressed in Chapter One, Secretary General of Section 65, Jorge Acedo Samaniego, described the strike of 1906 as a uniquely Mexican event. In his words, it was "pure as the snow on the peaks, there was no demagogue, there were no foreign doctrines," the absence of which had lent a unique shape to the Mexican Revolution. ${ }^{107}$ The strike of 1906 was often described as an eschatology, conjoining labor struggles with nationalist ones: "the history of Cananea. . . is that of the revolution, that of labor, that of redemption." 108 This historical association meant that the workers of Cananea were dedicated "to the best national vanguard causes." 109 But, while workers realized the need for industrialization and affirmed their patriotism, they would not serve national interests unconditionally: they wanted just and equal treatment, and demanded reciprocity from management and administrators, particularly from the company's Director General, Eduardo Prieto López."110 In 1906, Rafael Sánchez Velázquez warned that workers had limits and would be compelled to resume more direct forms of struggle if abuses persisted. ${ }^{111}$ During

107 “Discurso por el Co. Jorge Acedo-Srio. General Loc.," 1906, June 3, 1978.

${ }^{108}$ Rafael Sanchez Velazquez, "El Comportamiento del Movimiento Obrero ha Sido Decisivo Para Elevar la Producción," El Nacional, June 2, 1980.

109 Sergio Antonio Canale, "El Movimiento Obrero Como Puntal del Estado Mexicano," El Nacional, June 23, 1980.

110 "Primer Aniversario de la Mexicanización de la Cía. Minera de Cananea," 1906, August 26, 1972.

111 Rafael Sánchez Velázquez, "El Comportamiento del Movimiento Obrero ha Sido Decisivo Para Elevar la Producción," El Nacional, June 2, 1980; "Lucharemos por la Supervivencia de Cananea," 1906, December 3, 1977; Secretaria de Gobernación - Dirección General de Investigaciones Políticas y Sociales (DGIPS); "Mala Administración en Perjuicio de los Obreros," 1906, March 2, 1985. 
a meeting about workers' bonuses, one manager exhorted workers to work hard for the sake of work itself rather than for a pecuniary reward, declaring "We all are the Company." An editorialist responded with derision, claiming that workers would work hard when they were paid adequately and no longer had trouble feeding their families. ${ }^{112}$

Workers and citizens increasingly became disillusioned with the Mexican government and the Compañía Minera de Cananea. Critics faulted the government for appointing and tolerating administrators and managers who continued to violate the collective contract. The high cost of goods and the rationing of food in the wake of the debt crisis in 1982 eroded the legitimacy of both the company and the municipality from the perspective of Cananea's workers and townspeople. Enthusiastic patriotism relented to calls for greater vigilance and militancy. Secretary General Alberto Salcedo de Alto, of Section 65 , reminded union members of their predecessors in 1906 and urged them to protect the rights that had been won earlier, and to fight for future ones. The state had failed to redeem Cananea's historical legacy in its opposition to the repressive policies of Porfirio Díaz and the imperialist ambitions of the United States. ${ }^{113}$ Seventy-four years after the Mexican Revolution, what remained was

112 “Discriminación Económica,” 1906, February 4, 1978.

113 "Mala Administración en Perjuicio de los Obreros," 1906, March 2, 1985; "En Pie de Lucha," 1906, March 2, 1985; "Tortillas Racionadas y Bien Caras, Aquí no hay Control ni Autoridad," 1906, October 20, 1984; "Discurso Pronunciado por el Co. Alberto Salcido Del Alto, Secretario General de la Secc. 65," 1906, June 5, 1982; "Secciones Mineras Visitan y Apoyan la Sección 65," 1906, June 5, 1982; “¡Alto a los Impuestos! ¡Dejenos Vivir!” 1906, January 26, 1980. 
a constitution and a government that could only claim "revolutionary pretensions," defunct for the majority of the population but successful in advancing the goals of the elite..$^{114}$

As disillusionment grew, the bonds of the nation grew weaker among the workers in Cananea. Several writers emphasized the distance of Cananea "from the Mexican social, cultural, and economic structure," bridged only by "an increasingly weak historical link," which had been damaged more and more by persistent attacks on labor rights. ${ }^{115}$ One author described the 1917 Constitution as a defunct law that perpetuates a historical fiction that there ever existed a coherent Mexican nation served by a revolutionary state. ${ }^{116}$ Another writer condemned the failures of decision-makers who resided far from Cananea, in Mexico City, "where they devise thousands and thousands of solutions for the equitable distribution of the riches of our vast land."117 The concerns of Mexico City were not the same as those in Cananea. Workers' loyalty went neither to the company, the state, the Mexican Revolution, nor the ideology of revolutionary nationalism, but increasingly focused on the identity of the union itself, with an emphasis on the local rather than national leadership. ${ }^{118}$

\footnotetext{
114 “Revolución Mexicana o a La Mexicana," 1906, November 24, 1984.

115 “Un Marco de Referencia Necesario," 1906, September 24, 1983.

${ }^{116}$ Beatriz Eugenia Montijo H., "La Mentira," 1906, October 21, 1978.

117 “Qué es México?” 1906, November 24, 1979.

118 “Los Mismos Problemas, Cuando se Aproxima el Contrato," 1906, June 6, 1981.
} 
As the promises of Mexicanization diverged from its reality, workers also expressed their disillusion with the Mexican Revolution. Less than a decade after the company's change in ownership, the writers in 1906 lamented that "no so-called "revolutionary" has taken the country out of poverty, no "plan of the revolution" feeds us, nor does any revolutionary lead us, quite the opposite."119 Despite Cananea's mythical contributions to the revolution, the revolution had provided no reciprocal benefits for Cananea. In 1981, there existed "no guarantee of the right to health, medical assistance, nor the protection of the means of subsistence for a large part of the population."120 The murals and monuments celebrating Mexico's revolutionary past had "degenerated into marketing." ${ }^{21}$ The corruption of revolutionary ideals and proclamations of revolutionary achievements encouraged workers to view the Mexican Revolution as myth instead of reality. One author, in 1984 , argued that it was best to dispense with the myth of the Mexican Revolution, that the state would work on behalf of revolutionary principles, and that the achievement of national sovereignty had meant greater well-being for Mexicans. Preserving faith in a mythical revolution created a dependency that hindered active struggle. Only once ending that myth, could the struggle begin for the "justice and social wellbeing for all Mexicans."122

\footnotetext{
119 “Nuestra Solución es la Justicia, no la Producción ni Leyes," 1906, December 20, 1980.

120 "Un Pueblo Que no Quiere Morir," 1906, November 17, 1981.

121 ¿Qué es México?” 1906, November 24, 1979.

122 “Revolución Mexicana o a La Mexicana," 1906, November 24, 1984.
} 


\section{Conclusion}

From 1971 to 1989 , the Compañía Minera de Cananea embodied national sovereignty in the form of a parastate enterprise. The change in the company's ownership was as an assertion of total control of the mining industry, but the concrete gains were limited to those made by elites. Mexicanization succeeded in changing the monopoly character of mining and permitted the entry of the Mexican private sector into the mining industry. Government discourse asserted that foreign participation would strengthen national sovereignty. Instead, it established new forms of dependence. The fear that multinational corporations propagated imperialism in more covert ways belied the subtler penetration of foreign capital within parastate enterprises. By late 1980, Homero Urías argued that Mexicanization had succeeded in reorienting the mining industry toward domestic needs but had truly failed to gain control of mineral resources and remained subject to the vicissitudes of the global market. ${ }^{123}$

Mexicanization promised the achievement of national sovereignty, and the control of natural resources for the well-being of the Mexican people. With national control of resources, workers expected greater control of their economic and working lives. Instead, they experienced much the same conditions as before. The success of Mexicanization revealed itself in modernization projects and measured by production increases. Workers were told to sacrifice their

\footnotetext{
123 Urías, “¿Quién controla la minería mexicana?” 962.
} 
interests for national interests. What was good for the nation was good for them. As the expectations of Mexicanization diverged from workers' experience, the identification of labor and the Mexican nation, which had long been nurtured by the myth of Cananea, began to break down. After a long period of labor dormancy, the first strike in twenty years occurred in 1979, followed by strikes in 1981, 1983, and 1984. Any convergence between the workers of Cananea and the revolutionary state had disappeared by the mid-1980s, and the bonds of the nation weakened as workers returned to struggle. ${ }^{124}$

\footnotetext{
124 "Mejora la Compañía Minera de Cananea," El Nacional, June 21, 1980; "Minería en el Estado," 1906, November 27, 1982; "En Pie de Lucha," 1906, March 2, 1985; Informe, "Estalló a las 11:45 Horas La Huelga en la Cía. Minera de Cananea," Archivo General de la Nación, Secretaria de Gobernación, Dirección General de Investigaciones Políticas y Sociales, Box 1930B, Exp. 2, Folio 74/11342, January 18, 1981; Informe, "El Día de hoy, se reiniciaron las labores en la Compañía Minera de Cananea," Archivo General de la Nación, Secretaria de Gobernación, Dirección General de Investigaciones Políticas y Sociales, Box 1930-B, Exp. 2, Folio 74/11342, January 24, 1981.
} 


\section{CHAPTER V The Privatization of Compañía Minera de Cananea, 1989}

After centuries of foreign exploitation, the policy of Mexicanization meant sovereign control of mineral resources in Cananea. But less than two decades later, the Compañía Minera de Cananea was privatized by the administration of Carlos Salinas (1988-1994) during his first year of office. In the early morning hours of August 20,1989, the company was declared bankrupt and thousands of federal soldiers occupied its installations. For the next three months, the mines remained closed but on a daily basis generated national controversy and protest, largely as a result of Cananea's historical symbolism. At the same time, the controversies that erupted in Cananea were emblematic of larger structural changes in the country resulting from neoliberalism and privatization policies introduced at the beginning of the decade. The events brought about an abrupt end to a company more closely associated in the collective imaginary than any other with the Mexican Revolution.

With the exception of Petroleos Mexicanos, President Carlos Salinas had targeted the most historically symbolic parastate enterprise in the country through aggressive means. His ultimate success required the renegotiation of cultural myths associated with Cananea. The previous chapters of this dissertation have examined how the myth of Cananea fundamentally shaped the discourse of Mexican national sovereignty by establishing a connection between labor and the Mexican nation, providing legitimacy to the new revolutionary state, and by including labor into the corporatist structure of the ruling party. While the 
relationship between the Mexican state and labor had been cultivated for decades, the Salinas administration sought to destroy it.

The administration of Carlos Salinas sought to reorganize Mexican society, by eliminating the traditional connection between the working class and the nation. Where revolutionary nationalism emerged as the backbone of the predominant mode of accumulation throughout the twentieth century, it was replaced by neoliberalism toward the century's end. The main impediment to change, however, resided in labor, which had become an intrinsic part of the state's legitimacy since the Mexican Revolution, forged, in part, by the myth of Cananea. As revolutionary ideals increasingly diverged from reality in the second half of the twentieth century, the role of labor became less a means of legitimacy and more a source of contestation. So, when the privatization of the Compañía Minera de Cananea became a possibility in the late 1980s, labor protested the move as a threat to national sovereignty and the Mexican Revolution itself. The key challenge of privatization, then, involved the elimination of labor's larger association with the Mexican nation. ${ }^{1}$ Neoliberalism

\footnotetext{
${ }^{1}$ Claudio Lomnitz, Deep Mexico, Silent Mexico: An Anthropology of Nationalism (Minneapolis: University of Minnesota Press, 2002), 121; Alan Knight, "The Myth of the Mexican Revolution," Past and Present, no. 209 (Nov. 2010): 267-68; Kathy Powell, "Neoliberalism and Nationalism," in Dismantling the Mexican State? eds. Rob Aitken, Nikki Craske, Gareth A. Jones, and David E. Stansfield (Hampshire, U.K.: Macmillan Press, 1996), 50-51; Elvira Concheira Bórquez, El Gran Acuerdo: Gobierno y empresarios en la modernización salinista (México, D.F.: Ediciones Era, 1996), 71; Roger Bartra, Blood, Ink, and Culture: Miseries and Splendors of the Post-Mexican Condition (Durham: Duke University Press, 2002), 6; Rob Aitken, "Neoliberalism and Identity: Redefining State and Society in Mexico," in Dismantling the Mexican State? eds. Rob Aitken, Nikki Craske, Gareth A. Jones, and David E. Stansfield (Hampshire, U.K.: Macmillan Press, 1996), 24-27.
} 
and privatization eroded the key elements of revolutionary nationalism in Mexico and thus represented, "the first major hegemonic shift since the Revolution. . . perceived as an attempt to dismantle the Revolution, displacing its political symbolism."2 Central to this shift was the displacement of labor within the Mexican nation.

In this chapter, the privatization of the Compañía Minera de Cananea represents the fruition of a long-term effort to eliminate the social goals of the Mexican Revolution. This proceeded by dismantling the connection between labor and the Mexican nation. Some in Mexico, in particular segments of the ruling elite, considered the multiple efforts by the state to impose control over natural resources throughout the twentieth century to be proof of socialist or communist influences. But if one goes back in time, from the beginning, a more radical measure such as the takeover of the oil industry, for instance, was rather a move that rather than undermining it strengthened capitalism. The policy of Mexicanization, in turn, more clearly prioritized market forces over social issues, but even then, labor retained institutional representation and a key role in stateand nation-building. The goal of Salinas, then, was to eliminate all social considerations from economic policies and remove all forms of institutional representation of workers. Salinas redefined national sovereignty so that the social well-being of workers was no longer an issue. Only financial health and sound business practice would matter.

\footnotetext{
2 Powell, "Neoliberalism and Nationalism," 40.
} 
This chapter focuses on the association of Cananea with the working class, the nation, and the Mexican Revolution, and the attempts by the administration of Carlos Salinas (1982-1987) to deconstruct this association. It briefly examines the events that began on August 20,1989, the declaration of bankruptcy and the military occupation, collectively referred to as the big Sunday or "domingazo." The bulk of the chapter examines debates on the causes of bankruptcy and popular concerns of the bankruptcy's implications with respect to labor, national sovereignty, and the Mexican Revolution. These debates were collected from a number of, specially, regional, and national and regional newspapers, emphasizing the voices of journalists and politicians. Many of the newspapers published articles by intellectuals across the ideological spectrum. Newspapers that leaned left and were in the favor of Cananea's workers included El Sonorense, La Jornada, Unomásuno; centrist newspapers included El Universal and Excélsior; those reliably conservative included El Nacional and El Economista. 1906, the weekly union newspaper published by Section 65, remained out of print during this period. This chapter concludes by examining the attachment of new meanings to both national sovereignty and modernization.

\section{Background}

Social and economic problems had been simmering for a long time in Mexico but the debt crisis in 1982 provided the impetus toward national transformation. Economic decline and recession in the early 1970s reversed in a 
few years, after the discovery of new petroleum deposits, which reached a total of 45.8 billion barrels by late 1979. President José López Portillo used exports of oil to increase public borrowing to finance social and economic development projects. But after the price of oil collapsed in 1981, Mexico announced it might not be able to pay its debts thus triggering a wave of capital flight by the private sector. Out of desperation, López Portillo made one last use of direct state intervention in the economy when he nationalized the banking industry in September 1982, which further broke the already damaged relationship between the private sector and the state. This state of affairs changed immediately after the inauguration of President Miguel de la Madrid in December 1982 who renegotiated the debt and initiated Mexico's new stance toward neoliberalism. ${ }^{3}$

From the beginning, privatization was always a politically sensitive issue because of its potential effects on employment, the state's role in economic development, and national sovereignty over natural resources. The de la Madrid administration (1982-1988) indicated its clearest support for neoliberalism on May 6, 1983, when the Secretary of Energy, Mines, and Parastate Industry (SEMIP) announced its "intention to sell or liquidate 255 industrial parastate firms." ${ }^{4}$ The National Development Plan outlined the objectives of privatization,

\footnotetext{
${ }^{3}$ Peter H. Smith, "Mexico since 1946: Dynamics of an Authoritarian Regime," in Mexico since Independence, ed. Leslie Bethell (Cambridge: Cambridge University Press, 1991): 377-385; Miguel Angel Centeno, Democracy with Reason: Technocratic Revolution in Mexico (University Park: Pennsylvania State University Press, 1994), 71.

4 James M. Cypher, State and Capital in Mexico: Development Policy Since 1940 (Boulder, Colo.: Westview Press, 1990), 144.
} 
later implemented through the constitutional reforms of Articles 25, 26, 28 in 1983 and the Law of Federal and Parastate Entities in 1986. As a result, "desincorporación" became the official euphemistic term over "privatization," a more politically loaded one the government likely wished to avoid. Before the wave of privatizations reached Cananea in August 1989, 725 companies had undergone liquidations, mergers, transfers, and sales. ${ }^{5}$

While Mexico became engulfed in the debt crisis, a parallel crisis consumed the copper industry and the CMC. As the company began its final expansion project in 1982, the price of copper declined from $\$ 1$ per pound in 1980 to $\$ 0.65$ per pound by 1986 . This harmed the ability of Nacional Financiera (NAFINSA) to pay its loans and prompted it to look toward privatization as a way to reduce debts that reached nearly $\$ 700$ million dollars. Years before, NAFINSA had become the sole responsible agent for the CMC when the Atlantic Richfield Company sold its shares to NAFINSA in 1982, and when the shares of Banco Nacional de México were transferred to NAFINSA because of the bank nationalization. As a result, the Mexican government owned $99.8 \%$ of Cananea's stock by 1988. NAFINSA controlled three quarters (75.1\%), while the remaining portion went to the Mining Development Commission (24.7\%), with private investors owning just $0.2 \%{ }^{6}$

\footnotetext{
${ }^{5}$ Miguel D. Ramírez, "Privatization and the Role of the State in Post-ISI Mexico," in Privatization in Latin America: New Roles for the Public and Private Sectors, 1994, 27-28.

${ }^{6}$ Mark Eric Williams, Market Reforms in Mexico: Coalitions, Institutions, and the Politics of Policy Change (Lanham, Md: Rowman \& Littlefield Publishers, 2001), 76-77, 103, fn 72.
} 
Nacional Financiera made its first formal announcement for bids in January 1988. Cananea was originally to be sold to Grupo Protexa of Monterrey for 910 million dollars $(2,068,430,000$ pesos $)$ but the sale was canceled by Gustavo Petricioli, Secretary of Treasury and Director of NAFINSA on June 22, 1988. ${ }^{7}$ With the specter of privatization temporarily halted, Cananea subsided into a period of relative calm. After the initial bid collapsed, NAFINSA sought to lower labor costs discreetly in order to make the $\mathrm{CMC}$ more attractive to potential buyers. Management regarded the high wages and benefits for workers as a necessity, so NAFINSA replaced the director general in February 1989 with one more amenable to privatization. ${ }^{8}$ On June 21 , Section 65 , Cananea's local chapter of the national mining union, petitioned to go on strike before the renegotiation of their labor contract.

The situation exploded two months later, when the company declared bankruptcy and almost 3,000 soldiers of the Mexican Federal Army occupied the mine facilities during the early morning hours on Sunday, August 20, 1989. The mine workers, surprised at the state's forceful action, condemned the bankruptcy during an assembly later that day. The next day, Monday, August, 21, Luis Alberto Pérez Aceves, the acting director of the $\mathrm{CMC}$, announced the beginning of workforce liquidation while offering assurances that a majority of the workers

\footnotetext{
${ }^{7}$ Ricardo Vázquez, "Incertidumbre Financiera Sobre la Venta de Minera Cananea," El Día, May 17, 1988; J. Antonio Zuñiga M., "No se venderá la Minera Cananea al grupo Protexa, manifestó Gustavo Petricioli," Unomásuno, June 23, 1988.

${ }^{8}$ Williams, Market Reforms in Mexico, 77-78.
} 
would be rehired. The army withdrew from the mines on August 24th, and Financiera Nacional Azucarera, S.A. (FINASA) led by Salvador Trueba Rodríguez, took custody of the mines and operations of the CMC in bankruptcy. ${ }^{9}$ The domingazo - the bankruptcy and military occupation together unleashed widespread popular protest throughout the country. For the next three months, the events captured the attention of Mexicans, dominating the front pages and editorials of newspapers. Students, town councils, unions, political parties, and the Catholic Church published letters in the newspapers announcing their support for the miners and condemning the domingazo. The Workers' Union of the National Autonomous University of Mexico created a fund to sustain the Cananea Strike Committee. The miners of La Siderúrgica Lázaro CárdenasLas Truchas, in Michoacán, took the most dramatic action, when they announced their solidarity with Section 65 , and launched their own strike, certainly related to their own industrial grievances, on August 22. ${ }^{10}$

\footnotetext{
${ }^{9}$ H. Aranda y F. Santacruz, "Declaran en quiebra a la Compañía Minera de Cananea," Excélsior, August 21, 1989; Porfirio Muñoz Ledo, "Seguimiento hemerográfico sobre la quiebra de la Compañía Minera de Cananea, S.A. de S.V.," Centro de Informática Legislativa del Senado de la República, Dirección de Información y Analysis, August 29, 1989. Archivo Porfirio Muñoz Ledo, Actividad Legislativa, Cámara de Senadores, Hemerografía, Archivo General de la Nación, 2-3.

${ }^{10}$ Raúl Peralta Torúa, "Cananea, avance del conflicto," El Sonorense, September 4, 1989; Hermanos de Cananea del Ayuntamiento de Caborca, Letter, El Sonorense, August 24, 1989; La Unidad de los Trabajadores Fraternalmente, "Cananea: Un Golpe a la Constitución, a la Historia y al Pueblo," La Jornada, August 22, 1989; Reyes Fuentes Garcia Militante del PARM, "Deberán sanearse las paraestatales y no venderse; que se indentifique bien a los compradores," El Universal, September 6, 1989; "Sonora con Cananea," El Sonorense, August 24, 1989; Sección IX y XI BDD del SNTE, SAT, SUNTU, STUNAM, STUACH, SUTIN, UGOCP, SUTCIEAIPN, Coord. de Trab. del IMSS, STAUACH, SITUAM, SITRAJOR, COTRASE, Letter, "Acto en Defensa de Cananea: Cuna de la Revolución," La Jornada, September 1, 1989; Sindicato de Trabajadores de la Universidad Nacional Autónoma de México, Letter, Unomásuno, September 2, 1989; "A Nuestras Secciones Hermanas del Sindicato Minero a los Trabajadores del País, a la Opinión Pública," La Jornada, September 2, 1989.
} 
During the first week of the mine's closure, Cananea became host to numerous national politicians. Luis Donaldo Colosio, president of the PRI, represented the moderate face of the ruling party. The PRI had been facing a crisis of legitimacy since the presidential election of 1988, so his position was intended to express his support for workers and bolster the image of the PRI. In front of 3200 workers, Colosio supported a change in company-worker relations, but not through the means employed by Salinas. Declaring that the bankruptcy was not the fault of the workers, he asked for the immediate reopening of the $\mathrm{CMC}$ and the respect of the existing collective contract. ${ }^{11}$ His opposition was a tactical one and preceded the most anticipated visitor, Cuauhtémoc Cárdenas, who arrived a few days later. The son of President Lázaro Cárdenas, he represented the strongest oppositional voice against the bankruptcy and military occupation. He had created the Party of the Democratic Revolution in 1986 as an offshoot of the ruling PRI, to preserve revolutionary nationalism and the Mexican Revolution against the encroachment of neoliberalism. In Cananea, in front of a crowd of workers, he advocated for the preservation of labor rights and national sovereignty, a call that resulted in the creation of the National Patriotic Front a few weeks later. ${ }^{12}$

\footnotetext{
11 José Luis Durán King, “Cananea: 1989: la conmoción," El Nacional, August 31, 1989; A. Sepúlveda y F. Santacruz, "Reabrir Cananea de Inmediato y Respetar Derechos, Pide Colosio," Excélsior.

12 Manuel Sanchez Vite, "La Revolución, proceso perdurable," El Universal, September 3, 1989; Rosa Albina Garavito E., "De Fundidora a Cananea," La Jornada, September 1, 1989; Marco Antonio Vázquez Espinosa, "Modernización o contrarevolución," El Universal, August 29, 1989; Alberto Siles, "Se retiró completamente el Ejército de Minera Cananea," Unomásuno, August 26, 1989.
} 
Cananea's historical symbolism and its evocations of the 1906 strike were a common theme throughout the controversy and often intensified reactions. Raul Trejo Delarbe, an editorialist for La Jornada, wrote that Cananea persisted throughout the twentieth century as an important symbol of state legitimacy, combining "the revolutionary tradition, the worker spirit, the anti-imperialist epic."133 For many observers, such as Valentín Campa, the events of 1989 evoked memories of 1906, and seemed to represent the advent of an age of "neoporfirismo."14 Like Porfirio Díaz before him, President Salinas pursued a policy of modernization through force and violence that concealed the reactionary nature of his administration. The Popular Socialist Party accused Salinas and his twentieth century científicos of promoting the interests of foreign investors over the interests of the Mexican people, by handing over the national patrimony of the mines to foreign investors. Because of its resemblance to events in 1906 , August 20 became known as Green Sunday or Domingo Verde, recalling Cananea's original imperialist, William Greene. ${ }^{15}$

\footnotetext{
${ }^{13}$ Raúl Trejo Delarbe, “Cananea, memoria y presencia," La Jornada, August 30, 1989.

${ }^{14}$ Valentin Campa, "Es mentira porfiriana del presidencialismo lo de la quiebra de Cananea," Excélsior, October 2, 1989.

${ }^{15}$ La Unidad de los Trabajadores Fraternalmente, "Cananea: un golpe a la constitución, a la historia y al pueblo," La Jornada, August 22, 1989; Sindicato Nacional de Trabajadores Mineros, Metalúrgicos y Similares de la República Mexicana, Seccíon 65, "Al Presidente de la República Carlos Salinas de Gortari Al Pueblo de México," La Jornada, September 8, 1989; Partido Popular Socialista, "Manifiesto: A la Clase Obera, a las Fuerzas Patrióticas, Democráticas y Progresistas al Pueblo de México," El Imparcial, August 25, 1989; Lucinda Nava Alegria, "Científicos y modernizadores," El Universal, September 3, 1989; Margarita Otis, La ratonera: comentarios sobre Compañía Minera de la Cananea, 1971-1989 (Cananea, México: Paula Publishers, 1990), 4.
} 
The response to the domingazo also reflected negative attitudes toward the larger structural changes that had been taking place in Mexico throughout the 1980s. Previously, the politically sensitive nature of neoliberalism meant that the government had conducted privatization discreetly and obfuscated it with terminology such as "desincorporación."16 In part, Salinas and his administration justified this obfuscation by casting it as an economic issue rather than a political or social one. At the center of this debate was the economic development model, which had centered around a strong interventionist role of the Mexican state. ${ }^{17}$ The reexamination of the state's role, however, brought into play a much broader survey of the economic, political, and cultural structures in place since the Mexican Revolution. Cananea thus became emblematic of the larger changes taking place in the country. It is no wonder that an economic analyst remarked, "Cananea is a living and extraordinary example of the structural change that is taking place in our country in terms of the political and economic relations between the factors of production." 18

The problems in Cananea resurrected debates on the end of the Mexican Revolution, argued prominently during the 1950 s by Daniel Cosio Villegas. In his

\footnotetext{
${ }^{16}$ Raúl Díaz Ontiveros, “El costo social de una bancarotta,” El Nacional, August 24, 1989.

17 "La propiedad social, opción válida," El Día, August 26, 1989; Samuel Palma, "Cananea en la transformación," Unomásuno, September 2, 1989; Jorge Luis Ibarra, José Luis Moreno, and Leopoldo Santos, "Cananea: resistencias regionales a la política de modernización," in Cananea: tradición y modernidad en una mina histórica, eds. Oscar F. Contreras, Alejandro Covarrubias, Miguel Angel Ramírez, and Juan Luis Sariego Rodríguez (Hermosillo: Colegio de Sonora, 1998), 105.

${ }^{18}$ Rodolfo A. Menéndez, "Cananea: Dilema Económico Social," El Financiero, August 30, 1989.
} 
Historia moderna de México, Cosio Villegas claimed that the revolution had ended with President Lázaro Cárdenas and the nationalization of the oil industry. Similar proclamations, that the "Revolution" was dead or dying, intensified with the decline of economic growth and the student massacre at Tlatelolco in the late 1960s. The divergence between the ideals and the reality of the Mexican Revolution had become a apparent feature. Revolutionary nationalism remained a central component of the country's political culture and the legitimacy of the ruling party even into the 1980s, but its social character had been stripped of content . The events of 1989 in Cananea, however, represented a most significant strike against the Mexican Revolution. ${ }^{19}$ Echoing the myths of Cananea, Secretary General of Section 65, Octavio Bustamente Maldonado remarked, "here [in Cananea] the Revolution was born and. . . here it could die."20

The immediate concerns of Cananea's mine workers were more mundane, though. They feared that the mine's closure would lead to the permanent loss of jobs. But they were also aware that their livelihoods could be directly effected by a privatization that suggested a broader attack on labor rights, institutionalized labor protections, the country's independence, and its revolutionary past. In fact, President Carlos Salinas, his administration, and his

\footnotetext{
${ }^{19}$ Daniel Cosio Villegas, Historia moderna de México (México: Editorial Hermes, 1955); Carlos Ramírez, "¿Dónde se quebró la Revolución Mexicana? De movimiento a bandera; de historia a mito," El Financiero, July 1, 1988; León Garcia Soler, "A la mitad del foro," Excélsior, August 27, 1989.

${ }^{20}$ Manuel Sánchez Vite, “La Revolución, proceso perdurable,” El Universal, September 3, 1989.
} 
proponents were trying to implement their own revolution by renegotiating the meanings of national sovereignty, revolutionary nationalism, and the Mexican Revolution itself.

\section{Criticizing Labor}

The Salinas administration and its proponents criticized the political role of labor and the economic intervention of the state as contrary to sound business practice. The popular voices - students, unions, workers - against the bankruptcy claimed that the decision had been a political one, intended to weaken the union's strength and legitimacy, and to destroy the labor contract. But, the supporters of the bankruptcy argued that it had been a purely financial decision. By 1989, the debts of the CMC totaled $\$ 652$ million dollars, which included debts of 20 billion pesos to the national treasury, 25 billion pesos to various lenders, $\$ 67$ million dollars to American Express, and $\$ 578$ million dollars to Nacional Financiera. The government and its supporters presented calls for privatizing the company as pragmatic rather than motivated by any political considerations. In contrast, they considered workers' fears that the closure would lead to a permanent loss of jobs irrational and ideologically based. One editorialist reassured workers that the $\mathrm{CMC}$ remained an essential component of Mexican industry, that it was too important to be closed permanently, and so they had a good chance of being rehired. ${ }^{21}$

\footnotetext{
${ }^{21}$ Compañía Minera de Cananea, "A los Trabajadores de Cananea, al Pueblo de Cananea, a la Opinión Pública," El Dia, August 21, 1989; La Jornada, August 27, 1989; José Yuste, "Cananea: no repartir lo que no se produce," El Nacional, August 24, 1989; "Cananea vivirá," El Nacional, August 23, 1989.
} 
Several mainstream commentators, favorable to neoliberal solutions, argued that the company's problems had originated in 1971 with the company's Mexicanization, that is, when the state became involved. As per a local observer from Cananea, before the state's involvement, the CMC had been an exemplary enterprise when the company had been owned by Anaconda: "Neither the centralist "dedazo" nor the "polaca" in its worst forms, nor the irrational demagoguery of the union's unlimited conquests, existed then."22 Polaca was a pejorative expression to designate politics, and dedazo the method whereby candidates to political office, even the country's presidency, were not selected on merit but on the basis of being finger-pointed by political bosses. This and other observers thus blamed political interference and favoritism for the poor shape of the company.

Although political interference possessed a long history, the supporters of neoliberalism regarded it as endemic to socialism. Columnist Luis Pazos pointed out that the company's Mexicanization had occurred during the resurgence of the left under president Luis Echeverría, who allegedly had been convinced by Horacio Flores de la Peña, Secretary of National Patrimony, "to adopt the policies of state socialism."23 For the advocates of neoliberalism, the policies of the CMC were driven by politics and ideology, "demagoguery and populism,"

\footnotetext{
22 "Opiniones de un cananense," El Imparcial, September 9, 1989.

${ }^{23}$ Luis Pazos, "Estatismo y Cananea," Novedades, September 2, 1989.
} 
rather than rational and pragmatic decision-making for nearly twenty years. ${ }^{24}$ According to Pazos, the company's insolvency had revealed the true character of socialists, including Emilio Ocampo Arenal, the company's director from 1982 to 1988, who "condemn[ed] the profit of private capitalists" while using public and national companies to become rich. ${ }^{25}$

During his presidency Lázaro Cárdenas made synonymous the achievement of national sovereignty with state owned and managed enterprises. Over four decades later, this association had weakened in the minds of some Mexicans, and now it was widely believed that the participation of the Mexican state would destroy sound business practices. Alfredo Farrugía Reed, an editorialist in El Imparcial, a newspaper based in Hermosillo, the capital of Sonora, argued that "the government cannot be a good businessman, and therefore, it is impossible that it can administer a company with efficacy." ${ }^{26}$ Too often bureaucrats applied political logic to economic problems. Economic analysts faulted Echeverría's policies for having "provoked a false and ephemeral distribution of wealth based not on the noble concept of work, but on classic cronyism, [and] nepotism."27 The desire for steady growth promoted wasteful spending, the creation of unnecessary jobs, and the loss of profitability. ${ }^{28}$ Instead

\footnotetext{
24 "Cananea signo desastre," El Heraldo de México, August 22, 1989.

${ }^{25}$ Luis Pazos, “De Aeroméxico a Cananea," El Financiero, September 1, 1989.

${ }^{26}$ Alfredo Farrugía Reed, “Cananea, el desastre económico," El Imparcial, September 5, 1989.

${ }^{27}$ Lic. Juan Martínez Aldaz, “Cananea: una lección para todos," El Imparcial, September 5, 1989.

${ }^{28}$ Agustin Rodríguez Trejo, "Caras de la modernidad," Excélsior, August 24, 1989.
} 
of productivity, the company's operating model relied on subsidy. Economic analyst Luis Rubio condemned a business model, dependent on "the continuous flow of subsidies from the federal government. In this manner the company is preserved, [while] impoverishing the country." 29

For other critics, the real fault lied with the company's administrators who they blamed for corruption and the abuse of power. They also faulted the administration for having failed to anticipate labor costs and to control the company's finances by granting wage and benefits increases as short-term solutions to long-term labor problems, embraced without considering the company's long-term viability. As a potential confirmation of mismanagement in the hands of government administrators, a week after domingo verde, Emilio Ocampo Arenal, the company's director from March 1982 to March 1989, was arrested on charges of fraud. ${ }^{30}$

The events in Cananea demonstrated that the relationship between the labor and the state had fundamentally changed. Since the Mexican Revolution and the presidency of Lázaro Cárdenas, labor had become an institutionalized part of the Mexican state and essential to the legitimacy of the ruling party. By the 1980s, the state had become the antagonist of labor. Officials from the Secretary of Energy, Mines, and Parastate Industry (SEMIP) blamed the

\footnotetext{
${ }^{29}$ Luis Rubio, “Cananea y la bomba atómica," La Jornada, August 27, 1989.

30 "Iniciar la modernización en Cananea," El Universal, September 3, 1989; Hector Villegas Camman, "A todos conmueve," El Heraldo de México, September 9, 1989; Lourdes Galaz and Mario Peralta, "Preso, Ocampo A., ex Director de Cananea, por Fraude," Excélsior, August 30, 1989; Raúl Moreno Wonchee, "Relámpagos de Agosto," Excélsior, August 30, 1989.
} 
bankruptcy on the corruption of union leadership, but also blamed labor more generally as the source of the company's insolvency. ${ }^{31}$ Some critics distinguished between leaders and rank-and-file union members and argued that the former worked for their own self-interest while neglecting the needs of the latter. Director General of Financiera Nacional Azucarera, Salvador Trueba Rodríguez "admitted that the workers. . had nothing to do with the poor management and bankruptcy of the parastate." 32 In some cases, observers presented ordinary mine workers as victims of corruption and abuse of power rather than its perpetrators. They blamed the leadership of national unions for maintaining "corporate privileges" while disregarding the needs of the Mexican nation more generally. ${ }^{33}$

While some made a careful distinction between union leaders and its rankand-file members, many critics blamed labor in a more general sense. The management of the CMC argued that the decline of the company began with the signing of the union's first collective contract in 1932, which had normalized "inefficiency and lack of competitiveness." 34 They stated that mineworkers in Cananea received the highest wages in Mexico, 3.5 times more than other

\footnotetext{
${ }^{31}$ Adrian Lajous, "La quiebra de Cananea," El Informador, September 7, 1989; "Nacionalismo y resistencia sindical," Unomásuno, September 1, 1989.

32 “Iniciar la modernización en Cananea," El Universal, September 3, 1989.

${ }^{33}$ Nicolás Loza Otero, "Cananea: de privilegios corporativos y concertación," El Nacional, August 24, 1989.

${ }^{34}$ Compañía Minera de Cananea, "A los Trabajadores de Cananea, al Pueblo de Cananea, a la Opinión Pública," El Dia, August 21, 1989.
} 
workers in the country, and had transformed the sacrifices of their predecessors into a contract that protected a privileged sector of Mexican society. In addition, the company maintained a workforce double the necessary size, permitted workers "to miss three and a half months with pay," 35 and even "suspend[ed] operations in the middle of the day, on Sundays and holidays."36 These factors reduced the productivity of the company and resulted in higher costs of copper, increasing the costs of domestic manufacturing and reducing the competitiveness of exports. In 1989, Cananea was producing copper $33 \%$ more expensive than its global competitors. ${ }^{37}$

Those amenable to the new changes, expected workers and their unions to remain subservient to the Mexican nation, and to sacrifice their own needs for the needs of the company. Observers blamed unions and their members for demanding increases in wages and benefits year after year, making it difficult to control the company's finances and undermining the company's viability. It was the prerogative of unions to fight on behalf of its members, but many commentators encouraged them to moderate their demands in times of economic crisis. ${ }^{38}$ It seems workers had something else in mind.

\footnotetext{
${ }^{35}$ Luis Pazos, "De Aeroméxico a Cananea," El Financiero, September 11, 1989.

36 "Cananea signo desastre," El Heraldo de México, August 22, 1989.

${ }^{37}$ Compañía Minera de Cananea, "A los Trabajadores de Cananea, al Pueblo de Cananea, a la Opinión Pública," El Dia, August 21, 1989; Filiberto Alfaro Cazares, "Patrimonio histórico de México," El Dia, August 26, 1989; Olga Moreno Sofia, "Cananea: Historia de una Lucha," El Heraldo de México, August 23, 1989.

${ }^{38}$ Compañía Minera de Cananea, "A los Trabajadores de Cananea, al Pueblo de Cananea, a la Opinión Pública," El Dia, August 21, 1989.
} 
In June 1989, the union had asked for a $330 \%$ increase in salaries and benefits, which included additional paid vacation days, excusable absences, household expenses, celebrations, and school supplies. Advocates of the workers justified the demands by arguing that these were reasonable requests given inflation, the high cost of living in Cananea's geographical isolation, and the economic sacrifices already made by the working class such as that indicated by the Pact of Stability and Economic Growth signed in December 1988. The company's administration, in turn, claimed that such demands forced it into bankruptcy by exacerbating an already precarious financial situation and consuming liquidated funds needed for reinvestment and modernization. ${ }^{39}$

Even more sympathetic observers tended to ultimately agree with the goal of the domingazo. Several editorialists noted labor's historical contributions to the development of modern Mexico. They denounced the handling of the situation by Salinas, but they agreed with the end result of the bankruptcy as a necessary measure..$^{40}$ Journalist Raúl Delarbe Trejo, for instance, argued that labor had failed to take into account "new economic situations and new social facts," 41

\footnotetext{
39 "Iniciar la modernización en Cananea," El Universal, September 3, 1989; Compañía Minera de Cananea, "A los Trabajadores de Cananea, al Pueblo de Cananea, a la Opinión Pública," El Dia, August 21, 1989; "Editorial obrero," 1906, August 19, 1989; Mario Cappi Jarillo, "Definitivo, Jorge Larrea es el nuevo dueño de Minera Cananea," El Economista, August 23, 1990; "Cananea signo desastre," El Heraldo de México, August 22, 1989; Compañía Minera de Cananea, "A los Trabajadores de Cananea, al Pueblo de Cananea, a la Opinión Pública," El Dia; August 21, 1989.

40 Filiberto Alfaro Cazares, "Patrimonio histórico de México," El Día, August 26, 1989; "A manera de editorial obrero," 1906, November 19, 1988; Oscar Romo Salazar, "Buena medida...mal ejectudada," El Imparcial, August 24,1989.

${ }^{41}$ Raúl Trejo Delarbe, “Cananea, memoria y presencia,” La Jornada, August 30, 1989.
} 
which had their origins in the global crisis in the 1970s and the debt crisis of 1982. The new political and economic situation imposed "the exigencies of an increasingly acute international competitiveness that demands. . . higher levels of productivity." ${ }^{42}$ In the face of this situation, the union's demands were unreasonable. As per President Salinas, labor needed to adapt and the failure to do so would bring greater risks to Mexico. ${ }^{43}$ Even academics such as Eliezer Morales, director of the Economics department at UNAM, warned that if unions persisted in such demands there would be more cases like Cananea ${ }^{44}$

Privatization became a means of overhauling the traditional aspects of the economy that many observers in Mexico increasingly regarded as harmful to national interests. Editorialist Sara Lovera argued that Mexican unionism had resulted from a particular historical context in the first half of the twentieth century - the revolution, economic underdevelopment, and the central role of the state. While unionism had once served as "an effective instrument that permitted the state to promote industrial development," traditional unions had become an obstacle to generating creative and "imaginative" solutions to new problems. ${ }^{45}$ The continuation of populist policies and union patronage were harmful to the

\footnotetext{
42 "Una nueva Cananea," El Nacional, August 22, 1989; "Quiebra de Cananea," Novedades, August 22, 1989.

${ }^{43}$ Carlos Salinas de Gortari, "Segundo Informe de Gobierno," Revista Comercio Exterior (November 1990): 1113.

44 "Una nueva Cananea," El Nacional, August 22, 1989.

45 Sara Lovera, "Termina el sindicalismo que surgió de la Revolución," La Jornada, October 8 , 1989.
} 
wider interests of the nation and eliminating them was a need. ${ }^{46}$ Privatization would foster "a new Mexican Revolution" that would transform the nature of work and transform workers into efficient producers, capable of producing to match the products of globally competitive enterprises. ${ }^{47}$ In the business newspaper, El Financiero, Enrique Moreno Cueto argued that previous approaches to work rested on the foundation of cronyism and patronage rather than production: the blunt conclusion was that workers of Cananea claimed "the highest wages and standard of living and labor rights without having earned them." 48

\section{Defending Labor}

Contrary to the official position, the pro-worker public reaction argued that the bankruptcy was "a political decision, illegal and arbitrary."49 Many saw it as a pretense to privatize the company. If the sale of Cananea was premised on reducing the public debt, then the government had made a poor business decision:

In the previous seven years, the government, through NAFINSA, had made substantial investments in the mining company to expand its production, modernize its facilities and provide it with an export platform. Precisely when these improvements were concluded, and the CMC

\footnotetext{
46 "La quiebra de Cananea, fruto de un sindicalismo nefasto," El Sonorense, August 23, 1989; Carlos Galguera Ruiz, "Cananea, otro eslabón en la cadena," Unomásuno, September 7, 1989.

${ }^{47}$ Fernando Herrera Fernández, "La otra revolución," El Imparcial, August 29,1989.

${ }^{48}$ Enrique Moreno Cueto, "Cananea: nueva relación oberos-estado," El Financiero, August 31, 1989.

49 "Cananea: ofensiva antiobrera," La Jornada, August 26, 1989.
} 
became one of the most profitable export companies, the government decided to sell it. ${ }^{50}$

The supporters of the CMC also pointed to the historical legacy of the company. In a joint letter signed by multiple unions, the authors argued that the bankruptcy violated the 1917 Constitution because it "violently transgresses the historical rights of the Mexican working class, conquered in the revolutionary feat of 1910 that had its cradle precisely in Cananea." 51 The bankruptcy violated the right to strike but procedural irregularities and the abruptness and haste of judicial proceedings aroused suspicions when the paperwork for bankruptcy was filed in Mexico City, although the CMC's headquarters were in Cananea.

Through overwhelming force, the Mexican government ended the possibility of any successful intervention by the local union after bankruptcy was declared. The use of the military to occupy and shut down mining installations, violated Article 129 of the 1917 Constitution, which prohibited the use of the army in extra-military functions during peace time. ${ }^{52}$ Government officials claimed that the military was sent in to protect the mining installations from sabotage. In La Jornada, Enrique Calderón Alzati questioned their unsubstantiated claims, "To

\footnotetext{
${ }^{50}$ Oscar F. Contreras, Alejandro Covarrubias, Miguel Angel Ramirez, Juan Luis Sareigo Rodriguez, "Introducción general: lecciones de una tradición sindicalismo," in Cananea: tradición y modernidad en una mina histórica, eds. Oscar F. Contreras, Alejandro Covarrubias, Miguel Angel Ramírez, and Juan Luis Sariego Rodríguez (Hermosillo: Colegio de Sonora, 1998), 19.

${ }^{51}$ Sección IX y XI BDD del SNTE, SAT, SUNTU, STUNAM, STUACH, SUTIN, UGOCP, SUTCIEAIPN, Coord. de Trab. del IMSS, STAUACH, SITUAM, SITRAJOR, COTRASE, Letter, "Acto en Defensa de Cananea: Cuna de la Revolución," La Jornada, September 1, 1989.

52 Sección IX y XI BDD del SNTE, SAT, SUNTU, STUNAM, STUACH, SUTIN, UGOCP, SUTCIEAIPN, Coord. de Trab. del IMSS, STAUACH, SITUAM, SITRAJOR, COTRASE, Letter, "Acto en Defensa de Cananea: Cuna de la Revolución," La Jornada, September 1, 1989.
} 
protect them from what, or who? Perhaps there was danger of a foreign invasion? Or do there exist new armed guerrillas and we are not informed so as not to create uncertainty?"53 Despite the lack of casualties, the Partido Popular Socialista described the army's action as "moral and physical violence," intended to intimidate workers from striking. ${ }^{54}$ Journalist Oscar Romo Salazar wrote that such actions "correspond more to a repressive police state, rather than one in the process of modernization and democratization. ${ }^{55}$

More than any other parastate enterprise, Cananea possessed a long contentious history that symbolized labor's achievements and the endurance of labor militancy in the history of modern Mexico. Before August 1989, the policy of desincorporación had resulted in the privatization of 725 companies. None of these, however, shared the historical weight and symbolic resonance as the Compañía Minera de Cananea. Many commentators noted that the company's Mexicanization, less than two decades old, represented the achievement of Mexico's national sovereignty, the endurance of Mexico's revolutionary legitimacy, and a material expression of the revolution and of labor struggles. The company not only represented the historical achievement of national and popular sovereignty, but also was a source of employment and national

\footnotetext{
${ }^{53}$ Enrique Calderón Alzati, "Cananea: los sismos del 85 y los nazis," La Jornada, October 2, 1989; Heberto Castillo, "Cananea como en 1906," El Universal, August 23, 1989.

${ }^{54}$ Partido Popular Socialista, "Manifiesto: A la Clase Obera, a las Fuerzas Patrióticas, Democraticas y Progresistas al Pueblo de México," El Imparcial, August 25, 1989.

${ }^{55}$ Oscar Romo Salazar, "Buena medida...mal ejectudad," El Imparcial, August 24, 1989.
} 
economic development by which workers participated in the ongoing realization of the Mexican Revolution. ${ }^{56}$

The historical memory of Cananea had discouraged previous attempts to privatize the company and the government was well aware of this. ${ }^{57}$ So, fearful of the popular reaction, the Salinas government used the bankruptcy to maneuver around the symbolic blockade posed by Cananea's memory and to legitimize the company's sale. The bankruptcy became the means to eliminate the labor contract, weaken the union, and dismantle workers' rights, with the goal of transforming the workforce into one that was "docile and flexible." 58 The attack on Cananea was thus meant to destroy the primary symbol of the labor movement and its association with the revolutionary state. These changes would make the company more attractive to potential buyers, who set the termination of traditional labor relations as a precondition to purchase. ${ }^{59}$ The approach taken

\footnotetext{
${ }^{56}$ Edmundo Jardón Arzate, “¿Para eso votamos?” El Día, August 25, 1989. Leopoldo Santos Ramírez, "Cananea: encrucijada de México (I)," El Sonorense, September 4, 1989; Ignacio Castillo Mena, "Cananea, una política equivocada," El Economista, October 2, 1989; Mario Ezcurdia, "¿Se le pasó la mano al dogma privatizador?" El Día, August 27, 1989; Compañía Minera de Cananea, "A los Trabajadores de Cananea, al Pueblo de Cananea, a la Opinión Pública," El Día, August 21, 1989.

${ }^{57}$ Roberto Rodríguez Baños, "La mina desierta: símbolo y cicatriz," El Nacional, August 25, 1989.

${ }^{58}$ Frente Patriótica Nacional, "El país enfrenta un proceso contrarrevolucionario," La Jornada, September 6, 1989. "Nacionalismo y resistencia sindical," Unomásuno, September 1, 1989; Sección IX y XI BDD del SNTE, SAT, SUNTU, STUNAM, STUACH, SUTIN, UGOCP, SUTCIEAIPN, Coord. de Trab. del IMSS, STAUACH, SITUAM, SITRAJOR, COTRASE, Letter, "Acto en Defensa de Cananea: Cuna de la Revolución," La Jornada, September 1, 1989; Guadalupe Hernandez Garcia, Partido Popular Socialista, "Políticas porfirianas causan grave retroceso al desarrollo nacional," El Universal, September 6, 1989; Raúl Díaz Ontiveros, "El costo social de una bancarotta," El Nacional, August 24, 1989.

59 Edmundo Jardón Arzate, "¿Para eso votamos?" El Día, August 25, 1989; "Cananea: ¿Modernización patriótica?," El Sonorense, September 8, 1989; Adolfo Gilly, "Cananea," La Jornada, August 26, 1989; "La liquidación de Cananea es anticonstitucional," La Jornada, September 9, 1989; Gilberto Herrera Medina, "Cananea y la desgracia del trabajadore del cobre,"
} 
by Salinas "was welcomed. . . by investors and by the specialized press that treated it as being a further proof of the resolve of Salinas's government to modernize the Mexican economy." ${ }^{60}$ Destroying the most powerful symbol of labor would make probably future privatizations easier.

For the majority of Mexicans, however, an attack on state enterprises constituted an attack on the revolution. Historian Adolfo Gilly called neoliberalism "a Mexican counterrevolution." ${ }^{61}$ While some members of the Salinas administration observed in privatization a new stage of the revolution, others considered it a resurgence of political reaction, which appeared recurrentlly throughout the twentieth century. In El Financiero, Carlos Ramírez asserted,

to each revolutionary milestone corresponds a reactionary force in the opposite direction. . . the Callista pact corrected the course of the 1917 Constitution, the Alemanista pact halted the advance of Cardenismo, and the pact of the Delamadrista-Salinista seeks to stop the nationalizations of Echeverría and López Portillo. ${ }^{62}$

The assault on labor in Cananea, then, represented the next step in this reactionary tendency. Guadalupe Hernández Garcia of the Partido Popular Socialista considered Salinista measures a regression through a "counterrevolutionary economic policy that leads us to the loss of national

\footnotetext{
El Universal, August 22, 1989; Leopoldo Santos Ramírez, "Cananea: encrucijada de México (III)," El Sonorense, September 6, 1989.

60 Dolia Estévez, “Cananea: privatización,” El Financiero, September 1, 1989.

${ }^{61}$ Adolfo Gilly, “Cananea," La Jornada, August 26, 1989.

62 Carlos Ramírez, “¿Dónde se quebró la Revolución Mexicana? De movimiento a bandera; de historia a mito," El Financiero, July 1, 1988.
} 
independence and sovereignty." ${ }^{63}$ In other words, for her, to privatize the CMC was to destroy the Mexican Revolution. Workers sympathized.

Workers rejected the privatization of Cananea as an attack on national sovereignty. ${ }^{64}$ According to analyst Heberto Castillo, the privatization of nationalized industries represented a greater threat to sovereignty than any military aggression encountered in Mexico's history and was "even more dangerous because that aggression came from within." ${ }^{" 65}$ The National Patriotic Front of Cuauhtémoc Cárdenas protested that on behalf of modernization, the Salinas administration transformed Mexico into "[the] exclusive patrimony of an oligarchy and unarmed tributary of transnational companies." ${ }^{66}$ The policies of the Salinas administration, according to the Popular Socialist Party, "led to the cancellation of popular aspirations, to deprive the people of their sovereignty and the loss of national independence." ${ }^{67}$ National sovereignty implied the government's responsibility to advance the well-being of the Mexican people. Privatization meant the reverse, "the abandonment of the social responsibilities

\footnotetext{
${ }^{63}$ Guadalupe Hernández Garcia, Partido Popular Socialista, "Políticas porfirianas causan grave retroceso al desarrollo nacional," El Universal, September 6, 1989.

64 "La Unidad de los Trabajadores Fraternalmente, "Cananea: Un Golpe a la Constitución, a la Historia y al Pueblo," La Jornada, August 22, 1989.

${ }^{65}$ Heberto Castillo, "Nuestra independencia," El Universal, September 4, 1989.

${ }^{66}$ Frente Patriótica Nacional, "El país enfrenta un proceso contrarrevolucionario," La Jornada, September 6, 1989.

${ }^{67}$ Partido Popular Socialista, "Manifiesto: A la Clase Obera, a las Fuerzas Patrióticas, Democráticas y Progresistas al Pueblo de México," El Imparcial, August 25, 1989.
} 
of the State, the cession of sovereignty, contempt for the interests and values of the people, and the deliberate obstruction of a democratic perspective." 68

Many disapproving columnists pointed out that the neoliberal policies of the Salinas administration were not Mexican but the product of a foreign ideology that originated in American universities and institutions. ${ }^{69}$ Commentators such as Lucinda Nava Alegria pointed to the spread of neoliberal ideas through institutions such as the Heritage Foundation, the World Bank, and the International Monetary Fund, whose proposals sought modernization at the expense of "economic sovereignty, and at the expense of the elemental rights of Mexican workers."70 In El Sonorense, editorialist Miguel Angel Vázquez Ruiz suggested that Mexico's neoliberal policies were an extension of those previously imposed in South America, particularly Chile, which had been inspired by Milton Friedman and the Chicago School of Economics. ${ }^{71}$

In contrast, the ideology of revolutionary nationalism was praised as an autochthonous product of the Mexican Revolution, free of ideology and foreign influence. Commentators were quick to point out that the Mexican economy was capitalist, but a unique Mexican form of capitalism. Acquiescence to neoliberal

\footnotetext{
${ }^{68}$ Frente Patriótica Nacional, "El país enfrenta un proceso contrarrevolucionario," La Jornada, September 6, 1989.

${ }^{69}$ Mario Ezcurdia, “¿Se le pasó la mano al dogma privatizador?” El Día, August 27, 1989; Heberto Castillo, “¿México, S. A. de C. V.?,” El Universal, September 9, 1989.

${ }^{70}$ Lucinda Nava Alegria, "Científicos y modernizadores," El Universal, September 3, 1989; "La propiedad social, opción válida," El Día, August 26, 1989.

${ }^{71}$ Miguel Angel Vázquez Ruiz, "Cananea: Los alcances de la modernización," El Sonorense, September 5, 1989.
} 
institutions such as the International Monetary Fund would only relinquish Mexican national sovereignty. Critics argued that such measures would not actually alleviate the burden of public debt but promote social control through a new cycle of debt. Austerity measures and fiscal discipline became the key to establishing good credit in order to finance the payment of debt, but this strategy preserved the power of certain groups while delegitimizing others. ${ }^{72}$

Privatization was often presented as a novel cure for Mexico's troubles. Its supporters often presented private property in almost reverential terms, as "superior to the state and the social, it is a guarantee of efficiency and it is the guarantee of liberty and democracy." ${ }^{13}$ Supporters of the revolutionary state, in contrast, decried these associations:

Private property is not synonymous with efficiency, but with voracity; it can be, but not always, efficient, yet at the same time it is a source of antidemocracy in its management and in its objectives, and deeply unfair in the way of distribution. The maximum profit is the sole purpose of the capitalists, not the solution of social problems. ${ }^{74}$

Critics also pointed out that private property had always existed in Mexico. Even during the period of heightened state involvement in the economy in the 1970s, private property had been present alongside state and parastate enterprises.

The new emphasis on the merits of private property neglected its failures and

\footnotetext{
72 Guadalupe Hernández Garcia, Partido Popular Socialista, "Políticas porfirianas causan grave retroceso al desarrollo nacional," El Universal, September 6, 1989; Lucinda Nava Alegria,

"Científicos y modernizadores," El Universal, September 3, 1989.

73 "Cananea: ofensiva antiobrera," La Jornada, August 26, 1989.

${ }^{74}$ Eduardo Montes, "Modernizar es privatizar," La Jornada, September 2, 1989.
} 
shortcomings, and denied the positive role of the state in the growth of private business groups. ${ }^{75}$

One editorial declared that privatization was an unconstitutional maneuver. Article 27 detailed the state's responsibility to advance the "material and spiritual development of the Mexican people founded in social justice."76 The bankruptcy, the closure of the mines, and privatization itself were in opposition to the constitution since they threatened the social function of the CMC by creating unemployment and endangering the economic, political, and social stability of Cananea. Moreover, privatization would give private foreign capital, rather than any domestic authority, the power to determine national economic development. ${ }^{77}$

While neoliberals blamed many problems as intrinsic failures of the state, many in Mexico defended its economic role and laid the blame elsewhere. For Héctor Reyes Tirado, a pro-intervention writer, the failures of the CMC resulted from improper conduct and corruption by specific individuals. ${ }^{78}$ Editorialist Eduardo Montes somewhat agreed, claiming that individual bureaucrats and politicians were to blame: "the failure of such companies is because they have been handled precisely as the private property of the ruling political group,

\footnotetext{
${ }^{75}$ Eduardo Montes, "Modernizar es privatizar," La Jornada, September 2, 1989.

76 “Reprivatización y desnacionalización," Unomásuno, September 9, 1989.

77 “Reprivatización y desnacionalización,” Unomásuno, September 29, 1989.

${ }^{78}$ Héctor Reyes Tirado, “Las empresas estatales para los trabajadores," El Día, August 31,1989.
} 
without any democratic control, with bureaucratic methods and contaminated by the dominant corruption in public administration." ${ }^{" 79}$ In the end, many agreed that Cananea's unique problems failed to justify the total elimination of the state in economic development. ${ }^{80}$ The success of any enterprise under any type of socio-economic arrangement depended on "transparent finances and honest management; preconditions that operate for any type of industry." ${ }^{11}$ To further debunk the neoliberal arguments against state economic intervention, Petroleos Mexicanos (PEMEX) and the Federal Commission of Electricity were cited as examples of successful state intervention, and the complementarity of public and private ownership.

Many supporters of the $\mathrm{CMC}$ emphasized that state intervention had been essential in the development of private enterprise. Reyes Fuentes Garcia, a member of the left-leaning Party of the Authentic Mexican Revolution, noted that Cardenista policies were formative in the development of "the capitalist Mexican state" through expropriations often mistakenly labeled as socialist measures. ${ }^{82}$ His policies "permitted the pacification of the country, the control of the workers, the consolidation of the party in power and the subsequent development of a

\footnotetext{
${ }^{79}$ Eduardo Montes, "Modernizar es privatizar," La Jornada, September 2, 1989.

${ }^{80}$ Raúl Díaz Ontiveros, "El costo social de una bancarotta," El Nacional, August 24, 1989.

81 "Cananea y la rectoría económica," El Universal, August 24, 1989.

${ }^{82}$ Lic. Reyes Fuentes Garcia, "Deberán sanearse las paraestatales y no venderse; que se indentifique bien a los compradores," El Universal, September 6, 1989.
} 
national bourgeoisie." 83 The traditional weaknesses of the private sector and the need for economic development often demanded some form of sustained state intervention. Rather than a socialist policy, Mexicanization had been a policy that rescued bankrupt private enterprises, transferred them from foreign to Mexican control and rehabilitated them, largely in favor of domestic capitalists. ${ }^{84}$ In the process, the state established "a permanent source of subsidy to private capital" through enterprises such as oil, railroads, electricity, and telephones. ${ }^{85}$ Countering the myth of the protestant work-ethic, José Luis H. Ayala, member of the Party of the Revolutionary Worker, asserted that the success of the private sector was not the exclusive result of "its creativity and intelligence," but was tied to the availability of public investments granted through parastate enterprises. ${ }^{86}$

\section{Eliminating labor from nation}

The institutionalization of labor presented the greatest obstacle to neoliberalism. Where revolutionary nationalism provided a semblance of

\footnotetext{
83 Jose Luis H. Ayala, Miembro de la Comisión Sindical Nacional del PRT, "Urge que los obreros defiendan las paraestatales, producto de sacrificios de varias generaciones," El Universal, September 6, 1989.

84 Jorge Mendez, "Cananea 1906-1989," Excélsior, August 25, 1989; Guillermo Fabela Quiñones, "Reprivatizar no es modernizar," El Universal, September 9, 1989; Leopoldo Santos Ramírez, "Cananea no cree en lágrimas," El Sonorense, October 3, 1989.

${ }^{85}$ Eduardo Montes, "Modernizar es privatizar," La Jornada, September 2, 1989; Jose Luis H. Ayala, "Urge que los obreros defiendan las paraestatales, producto de sacrificios de varias generaciones," El Universal, September 6, 1989.

${ }^{86}$ Jose Luis H. Ayala, Miembro de la Comisión Sindical Nacional del PRT, "Urge que los obreros defiendan las paraestatales, producto de sacrificios de varias generaciones," El Universal, September 6, 1989.
} 
workers' participation in the state, "[t]he ideology of neoliberalism demand[ed] passivity from workers" and their subservience to the needs of the market. ${ }^{87}$ The persistence of revolutionary nationalism in the country's political culture demanded a redefinition of Mexican nationalism rather than its total replacement. So, in part, Salinas propounded a new ideology, social liberalism, an alleged "synthesis of the Reforma and the Revolution." ${ }^{88}$ This new nationalism consisted of "respect for freedom of belief, the need to give more participation to civil society, [and] the reaffirmation of the commitment to reverse poverty in popular neighborhoods and injustice in the countryside." ${ }^{\circ 9}$ On this basis, modernization through privatization became "a continuation of the progressive impulse of our libertarian struggles," modifying rather than forsaking the revolution..$^{90}$

Neoliberalism signified a drastic revision of state economic intervention. President Lázaro Cárdenas had created one paradigm of state participation in 1938 when the Mexican state fulfilled national sovereignty through the creation of fully state-owned enterprises. Mexicanization in 1961 combined state intervention with the participation of domestic and foreign investors. When neoliberalism became the fashionable strategy in the 1980s, privatization

\footnotetext{
${ }^{87}$ Rob Aitken, Nikki Craske, Gareth A. Jones, and David E. Stansfield. Dismantling the Mexican State? (Hampshire, U.K.: Macmillan Press, 1996), 27.

${ }^{88}$ Carlos Salinas de Gortari, "Cuarto Informe de Gobierno," (November 1, 1989), http://www.biblioteca.tv/artman2/uploads/4informe.pdf (accessed October 31, 2017 ), 29.

${ }^{89}$ Carlos Salinas de Gortari, "Cuarto Informe de Gobierno," (November 1, 1989), http://www.biblioteca.tv/artman2/uploads/4informe.pdf (accessed October 31, 2017), 30.

${ }^{90}$ Armando Cruz, "Será nacionalista y popular la modernización: Salinas," El Día, September 9 , 1989.
} 
entailed the complete elimination of the state from active economic participation. Eliminating the state, through bankruptcy in the case of Cananea, became an advantageous transfer of public financial resources to private capital by decreasing labor rights and selling the company at a lower cost. This probably contradicted one of the primary tenets of neoliberalism, an ideology against the interventionist role of the state. Instead of weakening, the character of state intervention simply changed, except this time to facilitate private interests. ${ }^{91}$ Weakening labor was another objective.

Although some regarded the bankruptcy as a purely financial matter, the same group of people failed to consider the possibility it could cause political instability and social unrest. Some commentators regarded the lack of such considerations a demonstrable weakness of neoliberal theory, which threatened to undermine the economic recovery and growth promised by privatization. By dismantling "the established framework for regulating the relations between the factors of production," ${ }^{92}$ Salinas-style modernization represented an attack on the corporatist model of governance, which had been in place since the creation of the PRM in 1938. Challenging the political role of labor threatened the legitimacy of state power and threatened as well to undermine the state's control of labor

\footnotetext{
${ }^{91}$ Aurora Berdejo A., "Frentes políticos," Excélsior, August 21, 1989; Alberto Barranco Chavarría, "Cananea en la encrucijada," La Jornada, August 11, 1989; Sección IX y XI BDD del SNTE, SAT, SUNTU, STUNAM, STUACH, SUTIN, UGOCP, SUTCIEAIPN, Coord. de Trab. del IMSS, STAUACH, SITUAM, SITRAJOR, COTRASE, Letter, "Acto en Defensa de Cananea: Cuna de la Revolución," La Jornada, September 1, 1989; Nora Hamilton, The Limits of State Autonomy: Post-Revolutionary Mexico (Princeton: Princeton University, 1982), 54.

92 Leopoldo Santos Ramirez, "Cananea: encrucijada de México (II)," El Sonorense, September 5, 1989.
} 
and, in consequence, the stability of the governing party more generally. The alienation of labor threatened to widen internal divisions in the PRI and push labor toward an alliance with the oppositional PRD, making it a stronger force against the current government and against social stability. ${ }^{93}$

For workers, their most immediate concern were their jobs. National sovereignty had been seen as a way to guarantee those jobs and preserve the labor protections established in the 1917 Constitution. They feared that privatization would eliminate their jobs, overturn the labor contract, destroy labor rights more generally, and create a neoliberal "paradise" for investment. ${ }^{94}$ Referring to neoliberal policymakers, historian Adolfo Gilly commented,

They want a country of defenseless and disorganized workers, without social protection, without contractual regulation of the rhythms and conditions of work, without safety standards in companies, a country without industrial unions. ${ }^{95}$

For the workers and people of Cananea, privatization, as an attack on labor rights and national sovereignty, threatened "to extinguish our historic roots." 96 The alliance between labor and the state had been replaced by "an alliance

\footnotetext{
${ }^{93}$ Raúl Díaz Ontiveros, "Cananea: modernidad a espaldas de los trabajadores," El Día, August 26, 1989; "La quiebra de Cananea en el conflicto social," El Día, August 23, 1989; Ricardo Pascoe Pierce, "Crisis del pacto social priísta," September 4, 1989; Marcos Shemaria Zlotorynski, "Cananea y lo laboral," El Informador, August 29, 1989; Mario Rivera Guzmán, "Del agreste Michoacán a Cananea proletaria," El Día, September 4, 1989; Alfredo Farrugía Reed, "Cananea, el desastre económico," El Imparcial, September 5, 1989.

${ }^{94}$ Heberto Castillo, "Solidaridad con los mineros," El Universal, August 25, 1989.

${ }^{95}$ Adolfo Gilly, "Cananea," La Jornada, August 26, 1989.

${ }^{96}$ Luis Gonzalez Souza, “Nuestra propia historia, en peligro,” El Día, September 4, 1989.
} 
between the State and the national and foreign private capitals." 97 This new alliance only magnified the growing uncertainty about jobs.

Salinas and his supporters sought to deconstruct the association of labor from the Mexican nation. Editorialist Edgard Mason argued that the association of Mexican national sovereignty with the interventionist role of the state had been invented through the nationalization of the oil industry and propagated through "textbooks," "the official history's political discourse," and "government propaganda." 98 He argued that state ownership nor bureaucratic oversight increase national sovereignty or guarantee positive outcomes for Mexico. On the contrary, Mason concluded "state companies often put into play the country's sovereignty and well-being when their inefficiencies, their corruption and others pushed them to exaggerate debt." ${ }^{99}$ Rodrigo Morales M. argued that the conflation of national sovereignty with state enterprises restricted the forms by which government officials could pursue structural changes even if they benefited the nation. ${ }^{100}$ President Salinas added that a nation incapable of competing in the global economy weakened its national sovereignty. ${ }^{101}$ Labor wanted to be a

\footnotetext{
${ }^{97}$ Raúl Díaz Ontiveros, "Cananea: modernidad a espaldas de los trabajadores," El Día, August 26, 1989.

${ }^{98}$ Edgard Mason V., "Estatismo y soberanía," El Informador, December 6, 1989.

${ }^{99}$ Edgard Mason V., "Estatismo y soberanía," El Informador, December 6, 1989.

${ }^{100}$ Rodrigo Morales M., "Nacionalismo en quiebra," La Jornada, September 6, 1989.

101 Carlos Salinas de Gortari, "Segudo Informe de Gobierno," Revista Comercio Exterior (November 1990): 1099.
} 
part of the nation, but neoliberalism sought to eliminate its existence as a distinctive bloc that needed institutional protection.

\section{Sound business practice}

Salinas and his supporters redefined the meaning of national sovereignty, so that it could not be achieved by direct economic production or management by the state but through the development of private industry and sound business practices. Rather than standards of living or wages, benefits to workers and the Mexican nation were to be measured in terms of the company's financial wellbeing. In a public letter, the company stated that its greatest challenges were the need for greater efficiency, productivity, and competitiveness. Many commentators agreed, the elimination or weakening of the union's participatory role in company affairs and in the political sphere would reduce interference and wastefulness from business operations. President Salinas claimed that the perceived harms of privatization would actually reduce the existing debt, lower the burden of public financing, and promote self-sufficiency. ${ }^{102}$ These changes would make the company more viable, increase its financial soundness, and bring long-term benefits for workers.

Sound business practices required engagement with foreign participation and global markets rather than isolation. Of course, for its entire duration as a

102 Compañía Minera de Cananea, "A los Trabajadores de Cananea, al Pueblo de Cananea, a la Opinión Pública," El Dia, August 21, 1989; "Cananea signo desaster,"El Heraldo de México, August 22, 1989; Carlos Salinas de Gortari, "Primer Informe de Gobierno," (November 1, 1989), http://www.biblioteca.tv/artman2/uploads/salinas1informe.pdf (accessed October 31, 2017), 44. 
parastate enterprise, the $\mathrm{CMC}$ had never excluded foreign participation; its connections to foreign technology, markets, and capital always remained intact. From the perspective of the Salinas administration, however, all forms of state economic participation suggested an anti-business approach. So, President Salinas asserted, "Sovereignty never meant [national] self-sufficiency or autarky." ${ }^{103}$ Interdependence did not contradict national sovereignty but strengthened it though engagement with other "sovereign nations." 104 Progovernment analysts argued that privatization and modernization were the key to saving and preserving their jobs, not the harbingers of their extinction. These programs would fulfill the Mexican Revolution, according to Salinas, by making the company globally competitive and financially viable. The modernization of the CMC would guarantee a source of employment and, in this way, would be nationalist and popular. ${ }^{105}$ Editorialists and columnists thus considered workers who protested after the domingazo to have renounced "a better future for all."106

The privatization of the $\mathrm{CMC}$ was legitimized by claiming that it would achieve the original goals of the revolution. Neoliberalism and the project of

\footnotetext{
${ }^{103}$ Carlos Salinas de Gortari, "Segudo Informe de Gobierno," Revista Comercio Exterior (November 1990): 1100.

${ }^{104}$ Carlos Salinas de Gortari, "Cuarto Informe de Gobierno," (November 1, 1989), http://www.biblioteca.tv/artman2/uploads/4informe.pdf (accessed October 31, 2017), 30, 59.

105 Samuel Palma, "Cananea en la transformación," Unomásuno, September 2, 1989; "Cananea: tradición y modernidad," El Nacional, October 6, 1989; "Viejos y nuevos puestos de trabajo," El Nacional, August 21, 1989; Carlos Salinas de Gortari, "Tercer Informe de Gobierno," Revista Comercio Exterior (November 1, 1991): 1069.
}

106 "Viejos y nuevos puestos de trabajol," El Nacional, August 21, 1989. 
privatization undertaken by Salinas comprised "the current stage of the Mexican Revolution." ${ }^{107}$ Modernization was not meant to be a replacement of national sovereignty but a new means toward its achievement. It was a strategy to improve global competitiveness, financial responsibility, institutional organization, and access to technology. Salinas claimed that such aspirations did not "contradict the autonomy of the country or social justice."108 He claimed that change would not destroy the Mexican Revolution but preserve it, secure its principles, and contribute to their advancement. ${ }^{109}$ In another speech, he remarked, "a country with a healthy and prosperous free enterprise economy can be and in fact is. . much more independent. . True sovereignty is not in the hands of a bureaucratic and arrogant elite, but in the hands of a prosperous people with an efficient and vigilant government."110

Many agreed that the model of economic development, originating from the Mexican Revolution, in which the state played a major economic role, had become defunct. Modernization was thus generally accepted but workers rejected the elite definition of it offered by Salinas. Modernization was a malleable notion. At the same time, it could be used to harness almost any program of change, often carrying a politically determined meaning. The

\footnotetext{
107 Carlos Salomon, “El camino modernizador de México," El Día, September 2, 1989.

${ }^{108}$ Carlos Salinas de Gortari, “Tercer Informe de Gobierno," Revista Comercio Exterior (November 1991): 1071.

${ }^{109}$ Carlos Salinas de Gortari, "Cuarto Informe de Gobierno," (November 1, 1989), http://www.biblioteca.tv/artman2/uploads/4informe.pdf (accessed October 31, 2017), 30.

${ }^{110}$ Edgard Mason V., "Estatismo y soberanía," El Informador, December 6, 1989.
} 
component of modernization most rejected by workers were its implications with labor relations, in which modernizers employed the euphemistic term "flexibility" to designate employers' freedom to hire, fire, and change the terms of employment, even lowering workers' salaries and benefits. ${ }^{111}$

Despite its alleged association with progress, in the hands of Salinas modernization became regressive in terms of labor protections. Modernizing the company implied the removal of social protections and the dismantling of the corporate relationship between labor and the state. Such changes would eliminate the labor contract, bring wage cuts, intensify work, reduce employment, and degrade workers' standard of living. ${ }^{112}$ According to its critics, Salinista modernization would "accentuate the enormous social inequalities and favor, even more, small groups and privileged sectors."113

Salinista modernization was also rejected because it was considered antidemocratic. In his campaign, Salinas had argued for greater democracy and political openness, in the way Mikhail Gorbachev called for perestroika and glasnost in the Soviet Union. ${ }^{114}$ Yet, observers argued that his economic policies

\footnotetext{
111 Luis Gonzalez Souza, "Nuestra propia historia, en peligro," El Día, September 4, 1989; Antonio Ponce M., "Comentarios," in Modernización y legislación laboral en el noroeste de México, eds. Felipe Mora and Victor Manuel Reynoso, Hermosillo: Colegio de Sonora, 1990), 291.

112 Adolfo Gilly, "Cananea," La Jornada, August 26, 1989; "A Manera de Editorial Obrero," 1906, November 19, 1988; Hector Barragan Valencia, "Modernizar, ¿Para qué?” Excélsior, September 8, 1989; Raúl Diaz Ontiveros, "Sindicalismo obrero en la encrucijada," El Día, September 4, 1989.

${ }^{113}$ Frente Patriótica Nacional, "El país enfrenta un proceso contrarrevolucionario," La Jornada, September 6, 1989.

114 Peter H. Smith, "Mexico since 1946: Dynamics of an Authoritarian Regime," in Mexico since Independence, ed. Leslie Bethell (Cambridge: Cambridge University Press, 1991): 396.
} 
and those of his predecessor had not been open to discussion and were being imposed by a small group of individuals. ${ }^{115}$ According to editorialist Enrique Quintana, the bankruptcy became a maneuver to eliminate discussion. He asked, "Was it impossible to negotiate with the union a collective bargaining agreement that would allow for the reorganization and efficiency of the company? Or, would it imply having to jointly agree and define the precise meaning of modernization in the company?"116 The events of Cananea revealed the possibility of imposing "economic modernization as a process exclusive of political modernization."117 Salinista modernization, like the Porfiriato, was aggressive, and threatened more violence as the attack on labor came to be seen as an attack on the prevailing social corporate structure of Mexico. The imposition of modernization through anti-democratic, forceful means ultimately threatened the success of any such program. ${ }^{118}$

Many rejected Salinas's elite modernization in favor of a popular one. Workers also rejected the notion that the company's privatization was the only possible solution to its problems. The workers of Cananea did not reject

\footnotetext{
115 Heberto Castillo, “¿México, S. A. de C. V.?” El Universal, September 9, 1989; Ramón Tirado Jiménez, "De la quiebra a la desincorporación," El Día, September 2, 1989.

${ }^{116}$ Enrique Quintana, “Cananea: ¿un estilo de concertar," El Financiero, August 28, 1989.

117 Enrique Moreno Cueto, "Cananea: Nueva Relación Oberos-Estado," El Financiero, August 31, 1989.

118 Dr. Clemente Avila Godoy, "Cananea: entre el mito y la realidad," El Sonorense, October 3, 1989; Raul Moreno Wonchee, "Relámpagos de Agosto," Excélsior, August 30, 1989; Hector Barragan Valencia, “Modernizar, ¿Para qué?” Excélsior, September 8, 1989.
} 
modernization but wanted to participate in defining its qualities. Instead of a modernization that invalidated the Revolution they wanted one in line with its principles. ${ }^{119}$ Workers wanted a modernization that was not associated with neoliberalism but one that "responds to the great objectives of the national project and whose orientation be nationalist, popular, and democratic." ${ }^{120}$ The National Patriotic Front of Cuauhtémoc Cárdenas announced: "On the contrary, we affirm that Mexicans are capable of promoting modernization in accordance with our sovereign principles and our social priorities, and that the technology or resources required from other countries must be managed through the control of workers and all Mexicans." 121 Many argued that it was possible to increase productivity and transform the CMC into a competitive company without ending protections for workers. The Mexican Revolution had already provided an alternative model that permitted a more ethical and socially-conscious capitalism. ${ }^{122}$ As one of the workers' supporters put it, Cananea's future owners "will not be able to operate even a single day, without having a few hundred workers. The machines do not work alone and the ovens do not turn on by

\footnotetext{
${ }^{119}$ Ariel González Jiménez, "Cananea: un debate crucial," El Nacional, August 24, 1989; José Martínez,"Cananea Sucumbe Ante los Proyectos de la Modernización; esa Area Quedará sin Vida," El Financiero, August 22, 1989.

120 "La semana pasada: verdadero debate político entre las fuerzas sociales," El Día, August 28, 1989.

${ }^{121}$ Frente Patriótica Nacional, "El país enfrenta un proceso contrarrevolucionario," La Jornada, September 6, 1989.

122 Lucinda Nava Alegria, "Científicos y modernizadores," El Universal, September 3, 1989.
} 
themselves." ${ }^{123}$ With President Salinas, the Mexican Revolution and the Compañía Minera de Cananea may have survived, but labor's position suffered irreparable damage. Salinista modernization had effectively removed the human and social touch from the state's relations towards the working class.

\section{Conclusion}

Almost three months after it occurred, the mine's closure brought economic ruin to Cananea. Without any other means of employment and subsistence, workers were compelled to give up their protest and renegotiate the labor contract in disadvantageous ways. The new contract modified retirement pensions and placed limitations on work rules, but Section 65 continued to exist as a representative of workers' needs. What had been fundamentally and irreparably damaged was the working relationship between labor and the company, which had been in place for decades. The company reopened in November 1989, but its actual privatization took almost an additional year, sold to Grupo Mexico, owned by Jorge Larrea, on September 28, 1990. Two years later, the new mining law eliminated the majority capital requirement, and permitted

\footnotetext{
123 Gilberto Herrera Medina, "Cananea y la desgracia del trabajadores del cobre," El Universal, August 22, 1989.
} 
any company of any origin to hold concessions as long as they abided by Mexican law. ${ }^{124}$

Where the myth of Cananea brought the working class within the domain of the nation in Mexico, the assault on Cananea by Salinas eighty-three years later was a fundamental attempt to destroy that association. Throughout the 1980s, the greatest impediment to structural change was a political myth in which labor functioned as a central element of state legitimacy. The myth of Cananea had tied the Mexican working class to the nation through the Mexican Revolution. President Cárdenas added another discursive element, so that national sovereignty became primarily expressed as the placement of valuable resources under the control of a state owned and operated enterprise. Mexicanization modified the meaning of national sovereignty in favor of the private sector, but even then, the institutional representation of labor remained intact, making it difficult to impose an agenda akin to the future neoliberal one.

Reducing the power of the working class required eliminating the positive association of labor with the Mexican nation in the myth of Cananea. Salinas revised the national character of the working class by removing it as an identifiable portion of the nation. After denigrating labor and the state, Salinas and his supporters offered a new ideal of national sovereignty to be achieved through sound business practices. Labor's worth was reduced to their abstract

\footnotetext{
124 Jose Garcia Segura, "Demandan sectores de la población inmediata reapertura de la mina," El Dia, September 5, 1989; Javier Velazques, "Tomó posesión Larrea de la cuprífera de Cananea," El Universal, September 27, 1990; Adrian Trejo Garcia, "Cananea comienza a reabrir sus puertas hoy: Humberto Mosconi," El Economista, November 7, 1989; "Ley Minera," Diario Oficial de la Federación, June 26, 1992. see article 11.
} 
market values. Whereas before foreign investors were the most likely violators of national sovereignty, it later became inefficient and unproductive workers who presented a greater threat to national sovereignty. By attacking Cananea, Salinas had taken one element of corporate society organized by Cárdenas and dissolved it, throwing it into the greater mass of the now undifferentiated Mexican people. 


\section{Conclusion}

In its examination of the "institutionalized" revolution, this dissertation looked at the myth of Cananea, the emergence of Mexicanization as a policy, its implementation in the $\mathrm{CMC}$, the short experience of the $\mathrm{CMC}$ as a Mexicanized company, and, then, its privatization. The study opened with four major questions. First, to what degree did the Mexicanization of the mining industry help achieve national sovereignty in Mexico? Second, how does the concept of national sovereignty provide insight into fundamental cultural assumptions related to natural resources, work, and the political organization of the world? Third, how does national sovereignty communicate perceptions of class, particularly the bifurcation of national sovereignty into popular and elite forms? Finally, how does national sovereignty emerge as a paradigm of economic norms that is, at once, opposed and complementary to, the hegemony of global capitalism and the organization of the world around the market?

Chapter one examined how the myth of Cananea established a relationship between labor and the nation. Before the 1906 strike, there had been no connection between the two entities. The loyalties of Mexican workers in Cananea resided with other workers, even Americans, more so than with any abstract nation. The rapprochement of labor by the Constitutionalists during the Mexican Revolution brought the working class within the boundaries of the nation, creating a foundation for the legitimacy of the new Mexican state, institutionalizing and incorporating the working class into the Mexican state. 
Through myth, workers came to be transformed from an undifferentiated mass into a distinguishable and coherent group - the nation's working class.

The second chapter dealt with elite concerns. The nationalization of oil created a set of discourses in which the dominant expression of national sovereignty became associated with direct state intervention in the economy, achieved through the state's exclusive ownership and management of a critical resource and the exclusion of both foreign participation and private involvement. The Mexicanization of mining altered this dynamic by changing state intervention so that it worked on behalf of private interests. Nationalist mining policy then emerges as a much more moderate and conservative expression of national sovereignty. In this process, the interests of the Mexican nation became more narrowly defined as the interests of the business sector in Mexico.

In chapter three, a strong interventionist role of the state in the economy emerged to promote the economic and social well-being of the Mexican people. As a result, the Mexican state became the embodiment of the nation's general interest or will. As such, workers occupied a distinctly subservient position. Their role transformed from active, with direct engagement in labor actions, to passive, one whereby Mexicans employed by Cananea and similar firms were supposed to work and sacrifice their own interests on behalf of the Mexican nation. Mexicanization of the CMC preserved the popular discourse of national sovereignty mentioned above and presented itself as the achievement of full national sovereignty despite the participation of foreign enterprise. 
In chapter four, the divergence between elite and popular notions of national sovereignty materialize outwardly. Economic indicators were the sole measure of elite national sovereignty by the 1970s. The praises of President Luis Echeverría and the company's modernization efforts suggest an image of success and financial well-being that differed drastically from the experience of Cananea's mineworkers. Workers expected Mexican control of the CMC to bring results for them through work security and control of their work. Instead, they were plagued by the same problems as those prevailing under the control of Anaconda. Except, now workers were asked to sacrifice themselves on behalf of the Mexican nation. Ultimately, the lack of reciprocity threatened the bond between the miners of Cananea and the Mexican nation.

In chapter five, President Carlos Salinas attacked, more frontally than any other leader ever did, the long-standing relationship between labor and the Mexican nation. His efforts vastly undermined the premises of revolutionary nationalism by transforming the interventionist role of the state in the economy. He also redefined the meaning of national sovereignty, eliminating the social well-being of workers as a component of it, and implementing economic measures that largely conformed to neoliberal impulses of the time. Although it became an ongoing process, Salinas began to take measures against the institutional representation of workers, eliminated their privileged position in Mexican society, and transformed them into an undifferentiated mass. 
In 1906, with the large protest it witnessed in favor of social protection for workers, Cananea became the alleged cradle of the Mexican Revolution; in 1989 , as part of a larger neo-liberal wave of reforms, Salinas made an effort to put it in its grave by declaring its bankruptcy, ordering its occupation by the military, and eventually privatizing the company, all of which represented the end of a close relationship between the state and labor. In between these extremes, there was a critical development - namely, Mexicanization. The Mexicanization of the Compañía Minera de Cananea, in 1971, represented a unique moment in the history of Mexico.

Mexicanization emerged as a hybrid policy, one that straddled the popular appeals of the Mexican Revolution and the elite shift toward neoliberalism. At the same time, the Mexicanization of mining ultimately demonstrates the victory of conservative forces in Mexico, which sought to dismantle the social promises of the Mexican Revolution, represented particularly by the radical nationalization of oil three decades before, in 1938. In the early 1970s, the Compañía Minera de Cananea found itself at a crossroads of the country's history - namely, the decline of the Mexican Miracle (and its multiple ramifications). This was a fairly unremarkable period if compared to the events at the beginning and end of the twentieth century.

At its outset, this study sought to assess the achievement of national sovereignty in mineral resources through the policy of Mexicanization. After decades of foreign ownership beginning in 1899 , the mines experienced a significant change in ownership in 1971 . That year, $51 \%$ of the company was 
sold out, bought by public and private Mexican interests. The policy differed significantly from the oil nationalization: it did not create state-owned or managed enterprises (except in special circumstances) and included the participation of private and foreign interests. The regime touted this change as a healthy nationalism, moderate and somewhat conservative. In contrast to the action taken by Cárdenas in 1938, the Mexicanization of mining in the last third of the twentieth century would seem to be a failure or, at least, a merely partial achievement of national sovereignty.

Still, the claim of the Mexican government was that national sovereignty was being achieved through majority capital control. While constituting a historical transition from complete foreign ownership, under Mexicanization foreign investors like Anaconda continued to own nearly half of the Compañía Minera de Cananea. The participation of foreign investors in Mexicanized industries seems to contradict the achievement of national sovereignty with respect to mineral resources. At the same time, the weakness of the Mexican ownership led to the division of the company's holdings among four or five different entities. This demonstrated that, at least on an individual basis, national control over the mining assets was substantially weaker. While Anaconda retained $49 \%$ of the company, the $51 \%$ of Mexican stockholders in the CMC was dispersed among different organizations: Nacional Financiera, Comisión de Fomento Minero, Banco Nacional de México, and Cobre de México. The holdings of each of the Mexican owners represented a fraction of Anaconda's total. So, while some authors emphasize the radical nature of Mexicanization, as 
per this study its moderate or weak character seems undeniable. Anaconda just complied with the minimum acceptable level of ownership according to the Mexicanization law.

The peaceful transition of Cananea's ownership thus opens up questions about the meaning of national sovereignty itself. Lázaro Cárdenas set the standard for achieving national sovereignty when he nationalized the oil industry in the late 1930s. At the same time, the oil nationalization was an extreme, totalizing assertion of national sovereignty that led to diplomatic disputes and economic boycotts. The Mexicanization of mining and of the CMC, in contrast, did not use economic coercion and preserved the participation of foreign investors. Although not as totalizing, Mexicanization did change the ownership structure of the mining industry in favor of Mexican interests.

Assessing the achievement of national sovereignty, then, would require asking whose sovereignty was achieved and whose interests were defined as national ones. If national interests are defined as a function of elite interests, then the achievement of national sovereignty through Mexicanization emerges as an adequate assessment of the historical events of 1971. If national sovereignty is defined as the achievement of popular interests, then such a claim is considerably weaker.

One of the most oft-told narratives about the Mexican Revolution espouses the progressive nature of the 1917 Constitution. But, hidden within its structure is a fairly conservative notion: the working class would be subordinate to the nation. Splitting the protections of workers and the sovereignty over 
resources, fundamentally weakened the former relative to the latter. Despite its institutional representation within the Mexican state, the working class itself possessed no sovereignty. The inclusion of workers' protections in the 1917 Constitution was a critical improvement essential to advancing the interests of labor in Mexico. Yet the progressive document imposed a social hierarchy in which workers were subordinate to the Mexican nation whose interests were predominantly defined by elites. This constitutional division of labor and natural resources ensured that labor was a factor of production that could be controlled and deployed according to national interests.

In this dissertation, I wanted to interrogate some of the fundamental assumptions by which people exist and operate in the world. Epistemological assumptions related to identity, social roles, facts, truth, and the reliability of one's senses, to name just a few examples, are often unspoken, unwritten, and unexamined. When I approached this project, I wanted to know about the fundamental assumptions concerning economic life and how economic norms are established, normalized, and perpetuated. The field of economics and economic understanding in general has succeeded in separating human life from economic life. Notions such as "homo economicus" too easily dismiss the social and cultural complexities of the economic world. Moreover, this perspective neglects the historical contingency of economic practices and the historical efforts by interested groups to impose economic norms. 
Culture too, often, emerges as an autonomous sphere of human life, often diametrically opposed to economic life. In this study, I consider the two definitively interrelated: culture is an intrinsic element of economic life and economic life is indelibly infused with culture. Works of cultural history have pursued economic issues, but these often concentrate on outward expressions of culture and perpetuate the notion that culture exists apart from the economic sphere. This study operates from the premise that economic activity is cultural activity. Engagement with natural resources through work requires cultural intervention because the materiality of the natural world does not possess intrinsic economic utility. Instead, this is the result of historical process and cultural manipulation in order to see such materials as resources to be shaped, molded, sold, and exchanged for another abstraction. Because economics is bound with politics, culture is also an intrinsic element of political economy. In capitalist societies, culture in the form of myth becomes necessary because the economic relationships revolve around exploitation, inequality, and hierarchy in the determination of who produces and who acquires the product of labor.

In this dissertation, I pursue these assumptions related to economic life in Mexico by analyzing the concept of national sovereignty. In contrast to a typical cultural history, the study examined sources that might be traditionally regarded as more appropriate for labor, political, or even economic history. This effort stems from a significant problem in trying to analyze the fundamental structures of economic life: the mineworkers of Cananea did not spend their spare time producing documents about their working lives. Based on the available 
resources, I focused on national sovereignty as a concept to gain insight into economic life. By analyzing national sovereignty from a cultural vantage point, I was able to examine the long-term structures of political economy, particularly, the relationships among key factors of production: land and labor.

I examined national sovereignty as a cultural matrix of modern industrial society in 20th century Mexico. This cultural matrix arranges and legitimizes the arrangement of the factors of production, labor and land, thus providing a framework for capital accumulation. In the schema offered by revolutionary nationalism, work and the exploitation of natural resources occurs for the benefit of the Mexican people, with the nation acting as the dominant reference. The state, representing the will of the people, asserts national sovereignty to advance the social well-being of the Mexican people. This arrangement provided a means for the state to assert control over natural resources, incorporate the working class into the national makeup, and provide a legitimate authority in the form of the nation.

National sovereignty embodied cultural ideals related to work and natural resources that originally represented a paradigm of economic life different from capitalism. National sovereignty indicated the possession and control of natural resources by the Mexican nation to be exploited for the benefit of the Mexican people. As national patrimony, the natural resources belonged to the Mexican people and were theoretically inalienable from them. Mineworkers in Cananea expected national control of the $\mathrm{CMC}$ to give them greater control over their labor. While work in the mines became a source of livelihood, it was also 
regarded as an activity with intrinsic value. Work was more than a means to get a paycheck and the source of the company's financial well-being, it was a means of self-realization for workers and a way to achieve the social goals of a nation forged by the Mexican Revolution.

At the same time, Mexican national sovereignty was defined and articulated within the context of global market capitalism. With mature capitalism, the social aspects of natural resources and work tend to disappear. In this context, the natural world possesses no intrinsic value other than as an economic resource to be exploited. Work bears no intrinsic value and becomes merely a commodity. The value of work is centered on production, efficiency, and profits economic indicators. Social issues and social consequences of work become an afterthought. Work is performed solely for the paycheck; social enrichment emerges as a coincidence or an afterthought. Mexican national sovereignty provided an alternate paradigm of economic life with respect to natural resources and work but its position within the larger global economy meant that copper mining at the Compañía Minera de Cananea had to adapt accordingly. The company's privatization and the state's attack against labor in Cananea in the late 1980s, demonstrate the victory of capitalism and market discourses, the elimination of social considerations, and the elimination of any alternate modes of economic life.

After the sale of the Compañía Minera de Cananea to Grupo Mexico in 1990, the equilibrium between the working class and the nation was never repaired. There were notable strikes from November 1998 to February 1999. An 
explosion killing 65 miners at the Pastas de Conchas coalmine in the state of Coahuila, also owned by Grupo Mexico, led to a three-year strike in Cananea from 2007 to $2010 .^{1}$ As in 1989 , these strikes were ended by threats of armed intervention and actual violence through the intervention of federal and state police. ${ }^{2}$ In 2012, the passage of a new federal Labor Law solidified the Mexican state's position against labor, taking away many labor victories and weakening the remainder including the right to form unions and the right to strike. ${ }^{3}$ In Cananea, history remains an ongoing and dynamic process and there is always the possibility labor can strike back. For the time being, though, at least in the mineral sector labor is not a driving force.

\footnotetext{
${ }^{1}$ David Bacon, "Mexican Miners' Strike for Life," The American Prospect (October 1, 2007), http://prospect.org/article/mexican-miners-strike-life (accessed June 7, 2016).

${ }^{2}$ Anne Fischel and Lin Nelson, "The Assault on Labor in Cananea, Mexico," Dollars and Sense, no. 290 (September/October 2010), http://dollarsandsense.org/archives/2010/0910fischelnelson.html (accessed June 7, 2016).

3 Juan Luis Sariego, "La interminable huelga de los mineros mexicanos de Cananea: ¿El final de un régimen laboral?" Amérique Latine Histoire et Mémoire 26 (December 2013): 2.
} 


\section{REFERENCES}

\section{Archives}

Archivo General de la Nación

Archivo Histórico de Nacional Financiera

Archivo Genderal del Estado de Sonora

Cananea Consolidated Copper Co. Records. Manuscripts Department. Arizona Historical Society. Tucson, AZ.

\section{Newspapers}

1906: semanario: órgano oficial de la Sec. 65 del S.I.T.M.M.S.R.M. Cananea, Son.: Sección 65 del Sindicato Minero Nacional, 1900.

Avance

Comercio Exterior

Diario Oficial de la Nación

El Día

El Economista

Excélsior

Financial Times

El Financiero

Heraldo de Cananea

El Heraldo de Mexico

El Imparcial

El Informador

La Jornada 
Los Angeles Times

El Nacional

New York Times

Novedades

El Nuevo Sonorense

Ovaciones

El Popular

La Prensa

Revista Comercio Exterior

El Sol de Mexico

Solidaridad

El Sonorense

Últimas Noticias

El Universal

Unomásuno

Wall Street Journal

\section{Primary Sources}

Abrams, Philip. "Notes on the Difficulty of Studying the State." Journal of Historical Sociology 1, no. 1 (1977/1978): 58-89.

Aguirre, Manuel J. Cananea: Las garras del Imperialismo en las entrañas de México. México, D.F.: Libro Mex Editores, 1958. 
Arellano Zavaleta, Manuel. Huelga de Cananea: 1906. México, D.F.: Comisión nacional editorial, 1976.

Avila Camacho, Manuel. Informe del Presidente Manuel Avila Camacho. México, D.F.: Centro de Documentación, Información y Análisis, 2006.

Baca Calderón, Esteban. Cananea. México: SEP-Conasupo, 1981.

Baca Calderón, Esteban. Juicio sobre la guerra del Yaqui y génesis de la huelga de Cananea. México, D.F.: Centro de Estudios Históricos del Movimiento Obrero Mexicano, 1975.

Cárdenas, Lázaro. Informe del Presidente Lázaro Cárdenas. México, D.F.: Centro de Documentación, Información y Análisis, 2006.

Compañia Minera de Cananea, S.A. Cananea y la revolución mexicana. Cananea: Compañía Minera de Cananea, 1987.

Compania Minera de Cananea, S.A. Compañía Minera de Cananea. Cananea: The Company, 1970.

Compañía Minera de Cananea. “Obras de Ampliación, 1973-1976." N.p.: n.p., 1976.

"Constitución Política de los Estados Unidos Mexicanos que Reforma la de 5 de Febrero del 1857," Diario Oficial 5, no. 30. February 5, 1917. 149-161.

Diario de los Debates de la Cámara de los Diputados del Congreso de los Estados Unidos Mexicanos

Diario de los Debates de la Cámara de los Senadores del Congreso de los Estados Unidos Mexicanos

Díaz Cárdenas, León. Cananea, primer brote del sindicalismo en México. México: Centro de Estudios Históricos del Movimiento Obrero Mexicano, 1976.

"Documents and Legislation Concerning the "Chileanization" of Anaconda's Chile Exploration Company." International Legal Materials 9, no. 5 (Sept. 1970): 921-974.

Echeverría A., Luis. "Primer Informe de Gobierno." In Seis Informes de Gobierno. Estados Unidos Mexicanos: Secretaría de la Presidencia, Direccíon General de Documentación e Informe Presidencial, n.d. 
http://www.biblioteca.tv/artman2/uploads/1971.pdf (accessed October 31, 2017).

Echeverría A., Luis. "Segundo Informe de Gobierno." In Seis Informes de Gobierno. Estados Unidos Mexicanos: Secretaría de la Presidencia, Direccíon General de Documentación e Informe Presidencial, n.d. http://www.biblioteca.tv/artman2/uploads/1972.pdf (accessed October 31, 2017).

Echeverría A., Luis. "Tercer Informe de Gobierno." In Seis Informes de Gobierno. Estados Unidos Mexicanos: Secretaría de la Presidencia, Direccíon General de Documentación e Informe Presidencial, n.d. http://www.biblioteca.tv/artman2/uploads/1973.pdf (accessed October 31, 2017).

Echeverría A., Luis. "Quinto Informe de Gobierno." In Seis Informes de Gobierno. Estados Unidos Mexicanos: Secretaría de la Presidencia, Direccíon General de Documentación e Informe Presidencial, n.d. http://www.biblioteca.tv/artman2/uploads/1975.pdf (accessed October 31, 2017).

Galindo, Magdalena. "El movimiento obrero en el sexenio echeverrista." Investigación Económica 4 (1977): 97-127.

González Cortés, Daniel. Cananea. México, D.F.: Compañia Minera de Cananea, 1985.

González Ramírez, Manuel. La huelga de Cananea. México, D.F.: Fondo de Cultura Económica. Fuentas Para la Historia de la Revolución Mexicana, III, 1956.

Hernández y Lazo, Begoña. Huelga de Cananea. México, D.F.: Comisión Nacional para las Celebraciones del 175 Aniversario de la Independencia Nacional y 75 Aniversario de la Revolución Mexicana, 1985.

La Botz, Dan. The Crisis of Mexican Labor. New York: Praeger, 1992.

La huelga de Cananea: tres monografías; contribución de los alumnos del primer curso de civismo, grupo "G" de la escuela secundaria núm. 6 , a la celebración del 1[grad] de mayo. México, D.F.: Tall. Gráf. de la Nación, 1936.

Leal, Juan Felipe. "The Mexican State: 1915-1973, A Historical Interpretation," Latin American Perspectives 2, no. 2, (Summer, 1975), 48-63. 
López Mateos, Adolfo. "El Lic. Adolfo López Mateos, al abrir el Congreso sus sesiones ordinarias, el $1^{\circ}$ de septiembre de 1960." In Informe del Presidente Adolfo López Mateos. N.p.: n.p., n.d. http://www.biblioteca.tv/artman2/uploads/1960.pdf (accessed October 31, 2017).

López Mateos, Adolfo. "El Lic. Adolfo López Mateos, al abrir el Congreso sus sesiones ordinarias, el $1^{\circ}$ de septiembre de 1961." In Informe del Presidente Adolfo López Mateos. N.p.: n.p., n.d. http://www.biblioteca.tv/artman2/uploads/1961.pdf (accessed October 31, 2017).

López Mateo, Adolfo. "El Lic. Adolfo López Mateos, al abrir el Congreso sus sesiones ordinarias, el $1^{\circ}$ de septiembre de 1964." In Informe del Presidente Adolfo López Mateos. N.p.: n.p., n.d. http://www.biblioteca.tv/artman2/uploads/1964a.pdf (accessed October 31, 2017).

Lozano Rocha, Erasmo. Monografía sobre el atraso de 50 años de Cananea: criticas y comentarios. Hermosillo, Sonora: Imparcolor, 1990.

Medina Hoyos, Francisco. Cananea: cuna de la Revolución Mexicana, en el cincuentenario de la primera gran huelga proletaria de México. México, D.F.: CTM, 1956.

México. Las huelgas de Cananea y Rio Blanco, 1906-1907. México, D.F.: Universidad Nacional Autónoma de México, 1983.

Meyer, Eugenia, Cynthia Rading, Martha Rocha, and Guadalupe Villa. La Lucha obrera en Cananea, 1906. México, D.F.: Secretaría del Trabajo y Previsión Social, 1980.

Molina Roqueñi, Felipe, Plácido Ríos, and Manuel Arellano Zavaleta. Huelga de Cananea, 1906. México, D.F.: PRI, Comisión Nacional Editorial, 1976.

Morales Tapia, Jesus. Los campos mineros de Cananea. México, D.F.: Compañía Minera de Cananea, 1985.

Oszlak, Oscar. "The Historical Formation of the State in Latin America: Some Theoretical and Methodological Guidelines for Its Study." Latin American Research Review 16, no. 2. 1981): 3-32.

Otis, Margarita. La ratonera: comentarios sobre Compañía Minera de la Cananea, 1971-1989. Cananea, México: Paula Publishers, 1990. 
Parodi, Enriqueta de. Mineros: la huelga de Cananea. N.p.: n.p., 1960.

Rubio Cubillas, Armando E. Huelga de obreros en Cananea. Hermosillo, Son., México: Imparcolor, 1990.

Ruiz Cortines, Adolfo. "El Sr. Adolfo Ruiz Cortines, al abrir el Congreso sus sesiones ordinarias, el $1^{\circ}$ de septiembre de 1957." In Informe del Presidente Adolfo Ruiz Cortines. N.p.: n.p., 1957. http://www.biblioteca.tv/artman2/uploads/1957.pdf (accessed October 31, 2017).

Salinas de Gortari, Carlos. "Primer Informe de Gobierno." N.p.: n.p., 1989. http://www.biblioteca.tv/artman2/uploads/salinas1informe.pdf (accessed October 31, 2017).

Salinas de Gortari, Carlos "Segudo Informe de Gobierno." Revista Comercio Exterior (November 1990): 1098-1113.

Salinas de Gortari, Carlos "Tercer Informe de Gobierno." Revista Comercio Exterior (November 1, 1991): 1069-1084.

Salinas de Gortari, Carlos. "Cuarto Informe de Gobierno." N.p.: n.p., 1992. http://www.biblioteca.tv/artman2/uploads/4informe.pdf (accessed October 31, 2017).

Sayeg Helú, Jorge. Las huelgas de Cananea y Río Blanco. México, D.F.: Patronato de Instituto Nacional de Estudios Históricos de la Revolución Mexicana, 1980.

Secretaría de Gobernación. "Decreto que reforme los párrafos cuarto, quinto, sexto y séptimo, fracción I del artículo 27 y los artículos 42 y 43 de la Constitución Política de los Estados Unidos Mexicanos," Diario Oficial, 238, no. 16. January 20, 1960. 1-3.

Secretaría de Gobernación. "Ley Reglamentaria del Artículo 27 Constitucional en materia de explotación y aprovechamiento de recursos minerales," Diario Oficial, 244, no. 31. February 6, 1961. 1-16.

Secretaría del Patrimonio Nacional. "Reglamento de la Ley Reglamentaría del Artículo 27 Constitucional en Materia de Explotación y Aprovechamiento de Recursos Minerales," Diario Oficial, 250, no. 49. February 28, 1962. 132. 
Sosa Ballesteros, Julio. Cananea: un pueblo que jamás morirá. Ciudad Centenaria - Álbum Fotográfico, 1901-2001. Cananea: Julio Sosa Ballesteros, Cronista Oficial de la Ciudad, 2001.

Tapia Quijada, César. Apuntes sobre la huelga de Cananea. Hermosillo: Universidad de Sonora, 1956.

Torrance, Robert F. Manuscripts Collection. Arizona Historical Society, Tuscon, Arizona, University of Arizona.

Trejo Delarbe, Raúl, and Aníbal Yanez. "The Mexican Labor Movement: 19171975." Latin American Perspectives 3, no. 1, Imperialism and the Working Class in Latin America (Winter, 1976): 133-153.

Trueba Lara, José Luis. Cananea, 1906. Sonora: Gobierno del Estado de Sonora, 1989.

Trueba Lara, José Luis. Crónica de una venta anunciada. Simposio de Historia y Antropología de Sonora. Hermosillo, Son.: Instituto de Investigaciones Históricas, Universidad de Sonora, 1991.

Trueba Lara, José Luis. Voces de la mina: seis textos sobre Cananea. Hermosillo, Son.: Programa Cultural de las Fronteras, 1988.

Urías, Homero. "iQuién controla la mineria mexicana?" Comercio Exterior 30 (September 1980): 949-965.

Valencia Ortega, Ismael. Cananea. Hermosillo, Son.: INAH-SEP, Centro Regional del Noroeste, 1984.

\section{Secondary Sources}

Acle Tomasini, Alfredo, and Juan Manuel Vega Hutchison. La empresa pública: Desde fuera, desde dentro. México, D.F.: Instituto Nacional de Administración Publica, Editorial Limusa, 1986.

Aguilar Camín, Héctor, and Lorenzo Meyer. In the Shadow of the Mexican Revolution: Contemporary Mexican History, 1910-1989. Translated by Luis Alberto Fierro. Austin: University of Texas Press, 1993.

Aguilar Camín, Héctor. La Revolución Sonorense, 1910-1914. México, D.F.: INAH, 1975. 
Aitken, Rob, Nikki Craske, Gareth A. Jones, and David E. Stansfield. Dismantling the Mexican State? Hampshire, U.K.: Macmillan Press, 1996.

Alexander, Jeffrey, C. "Market as Narrative and Character: For a Cultural Sociology of Economic Life." Journal of Cultural Economy 4, no. 4 (November 2011): 477-488.

Anaconda. This is Anaconda. New York: Anaconda, 1960.

Anderson, Rodney D. Outcasts in Their Own Land: Mexican Industrial Workers, 1906-1911. DeKalb: Northern Illinois University Press, 1976.

Anglade, Christian, and Carlos Fortín. The State and Capital Accumulation in Latin America: Volume One - Brazil, Chile, Mexico. London: Macmillan, 1985.

Arcangeli, Alessandro. Cultural History: A Concise Introduction. New York: Routledge, 2012.

Arellano Rendón, Francisco. El subsuelo mexicano: patrimonio nacional. México: [s.n.], 1970.

Arés, Mathieu. "El estado empresario: Nacional Financiera durante la industrialización por sustitución de importaciones (1934-1994)." Foro Internacional 188 (vol. 47, no. 2 (April-June 2007): 201-243.

Arrighi, Giovanni. The Long Twentieth Century. London: Verso, 1994.

Ashby, Joe. Organized Labor and the Mexican Revolution under Lázaro Cárdenas. Chapel Hill: University of North Carolina, 1967.

Aspe, Pedro. El camino de México hacia la modernización. México, D.F.: Fondo de Cultura Económica, 1994.

Aubey, Robert T. Nacional Financiera and Mexican Industry; A Study of the Financial Relationship between the Government and the Private Sector of Mexico. Los Angeles: UCLA, 1966.

Babb, Sarah. Managing Mexico: Economists from Nationalism to Neoliberalism. Princeton, NJ: Princeton University Press, 2001.

Bacon, David. "Mexican Miners' Strike for Life." The American Prospect (October 1, 2007), http://prospect.org/article/mexican-miners-strike-life (accessed June 7,2016$)$. 
Banco Nacional de México. Banco Nacional de México: su historia, 1884-2004. México, D.F.: Banamex, 2004.

Bantjes, Adrian A. As If Jesus Walked on Earth: Cardenismo, Sonora, and the Mexican Revolution. Wilmington, D.E.: Scholarly Resources, 1998.

Barbero, Maria Ines. "Business History in Latin America: A Historiographical Perspective." Business History Review 82, no. 3 (2008): 555-575.

Bartra, Roger. Blood, Ink, and Culture: Miseries and Splendors of the PostMexican Condition. Durham: Duke University Press, 2002.

Basave Kunhardt, Jorge. Los grupos de capital financiero en Mexico (19741995). México, D.F.: El Caballito/IIE/UNAM, 1996.

Basurto, Jorge. "The Late Populism of Luis Echeverría." In Latin American Populism in Comparative Perspective, edited by Michael L. Conniff, 93111. Albuquerque: University of New Mexico Press, 1982.

Baughman, James P. "Recent Trends in the Business History of Latin America." The Business History Review 39, no. 4, Special Latin American Issue (Winter, 1965): 425-438.

Becerra González, María. Derecho Minero de México y Vocabulario con Definición de Conceptos Jurídicos-Mineros. México, D.F.: Editorial Limusa-Wiley, 1963.

Becerra González, Maria. Principios de la Constitución Mexicana de 1917: relacionados con el subsuelo, antecedents doctrinales y legislativos, principios fundamentales contenidos en la constitución en su versión original y cambios operados después de 1917 en el mismo texto constitucional. México, D.F.: Universidad Nacional Autónoma de México, 1967.

Benjamin, Thomas. La Revolución: Mexico's Great Revolution as Memory, Myth \& History. Austin: University of Texas Press, 2000.

Bennett, Douglas C., and Kenneth Sharpe. "The State as Banker and Entrepreneur: The Last-Resort Character of the Mexican State's Economic Intervention, 1917-1976." Comparative Politics 12, no. 2 (1980): 165-189.

Benson, Peter, and Stuart Kirsch. "Capitalism and the Politics of Resignation." Current Anthropology 51, no. 4 (August 2010): 459-486. 
Bensusán, Graciela, and Kevin J. Middlebrook. Organized Labour and Politics in Mexico: Changes, Continuities, and Contradictions. London: Institute for the Study of the Americas, University of London, 2012.

Bergquist, Charles. Labor in Latin America: Comparative Essays on Chile, Argentina, Venezuela, and Colombia. Stanford: Stanford University Press, 1986.

Bernstein, Marvin D. The Mexican Mining Industry,1890-1950: A Study of the Interaction of Politics, Economics, and Technology. Albany: State University of New York Press, 1965.

Bernstein, Marvin. "Colonel William C. Green and the Cananea Copper Bubble." Bulletin of the Business Historical Society (December 1952): 179-198.

Besserer, Federico, Victoria Novelo, and Juan Luis Sariego. El sindicalismo minero en México, 1900-1952. México, D.F.: Ediciones Era, 1983.

Besserer, F., J. Díaz, and R. Santana. "Formacion y consolidacion del sindicalismo minero en cananea." Revista Mexicana De Sociología 42, no. 4 (1980): 1321-1353.

Biersak, Aletta, and Lynn Hunt, eds. The New Cultural History. Berkeley: University of California Press, 1989.

Blair, Calvin. "Nacional Financiera: Entrepreneurship in a Mixed Economy." In Public Policy and Private Enterprise in Mexico, edited by Raymond Vernon, 193-240. Cambridge, Mass.: Harvard University Press, 1964.

Bonnell, Victoria E., and Lynn Hunt, eds. Beyond the Cultural Turn: New Directions in the Study of Society and Culture. Berkeley: University of California Press, 1999.

Borek, Theodore B. "Evaluating a Developing Institution: Mexicanization of Mining," Arizona Law Review 13, no. 3 (1971): 673-702.

Braudel, Fernand. The Perspective of the World. Volume 3 of Civilization and Capitalism, 15th-18th Century. Translated by Sian Reynolds. Berkeley: University of California Press, 1992.

Braudel, Fernand. The Wheels of Commerce. Volume 3 of Civilization and Capitalism, 15th-18th Century. Translated by Sian Reynolds. Berkeley: University of California Press, 1992. 
Brown, Jonathan. Oil and Revolution in Mexico. Berkeley: University of California, 1993.

Brown, Jonathan C. Workers' Control in Latin America, 1930-1979. Chapel Hill: University of North Carolina Press, 1997.

Brown, John, and Alan Knight, eds. The Mexican Petroleum Industry in the Twentieth Century. Austin: University of Texas Press, 1992.

Browning, Anne. "Mexican Mineral Policy Changes and Their Impact on the Lives of Cananea Copper Miners, 1960-1990." In IV Congreso internacional de historia de la minería, edited by Inés Herrera Canales y Jesús Franco Ibarra, 1-16. CD-ROM. México, D.F.: Dirección de Estudios Históricos - Instituto Nacional de Antropologia e Historia, 2000.

Browning-Aiken, Anne. "The Transformation of Mexican Copper Miners: The Dynamics of Social Agency and Mineral Policy as Economic Development Tools." PhD diss., University of Arizona, 2000.

Browning, David S. "Historic Basis of Mining Law," Inter-American Law Review 7 , no. 1 (January - July 1965): 1-31.

Brown, Kendall W. A History of Mining in Latin America. Albuquerque: University of New Mexico Press, 2012.

Bucheli, Marcelo. Bananas and Business: The United Fruit Company in Colombia, 1899-2000. New York: New York University Press, 2005.

Bulmer-Thomas, Victor. The Economic History of Latin America Since Independence. 3rd Edition. Cambridge: Cambridge University Press, 2014.

Burgin, Angus. The Great Persuasion: Reinventing Free Markets since the Depression. Cambridge, Mass.: Harvard University Press, 2012.

Burke, Peter. "Strengths and Weaknesses of Cultural History." In Cultural History 1, no. 1 (2012): 1-13.

Byrne, Sister Martin. "Cananea Consolidated Copper Company from Nationalization to Privatization: 1972-1991. International Journal of Public Administration 23, nos. 5-8 (2000): 563-577.

Cabello Rosales, Maria Alejandra. La intermediación y estructura financiera de NAFINSA, 1974-1981. México, D.F.: Universidad Nacional Autonoma de Mexico, Facultad de Contaduria y Administracion, 1983. 
Camp, Roderic A. Entrepreneurs and Politics in Twentieth-Century Mexico. New York: Oxford University Press, 1989.

Cárdenas, Enrique, José Antonio Ocampo, and Rosemary Thorp, eds. An Economic History of Twentieth-Century Latin America. Houndsmills, Basingstoke, Hampshire, U.K.: Palgrave, 2000.

Cárdenas, Nicolás. Empresas y trabajadores en la gran minería mexicana, 19001929. México, D.F.: Instituto Nacional de Estudios Históricos de la Revolución Mexicana, 1998.

Cárdenas García, Nicolás. "La huelga de Cananea en 1906: una reinterpretación." Estudios Sociológicos 16, no. 46, (enero/abril 1998): 117-146.

Cardoso, Ciro, Flamarion Santana, Francisco G. Hermosillo, and Salvador Hernández. De la dictadura porfirista a los tiempos libertarios. México, D.F.: Siglo Veintiuno Editores, 1985.

Carmona Amoros, Salvador. La economía mexicana y el nacionalismo Revolucionario. México, D.F.: Ediciones "El Caballito," 1974.

Carrillo Castro, Alejandro, and Sergio Garcia Ramírez. Las empresas públicas en México. México, D.F.: Miguel Ángel Porrúa, 1983.

Carroll, William K., and Meindert Fennema. "Is There a Transnational Business Community." International Sociology 17, no. 3 (2002): 393-419.

Catálogos del Archivo Histórico de Compañía Minera de Cananea. Cananea, Son.: Centro Cultural Minera de Cananea, 1988.

Centeno, Miguel Angel. Democracy with Reason: Technocratic Revolution in Mexico. University Park: Pennsylvania State University Press, 1994.

Chong, Alberto, and Florencio López-de-Silanes, eds. Privatization in Latin America: Myths and Reality. Palo Alto, Calif.: Stanford Economics and Finance; Washington, D.C.: World Bank, 2005.

Cline, Howard F. Mexico: Revolution to Evolution, 1940-1960. New York: Oxford University Press, 1962.

Cochoy, Frank, Martin Giraudeau, and Liz McFall. "Performativity, Economics and Politics." Journal of Cultural Economy 3, No. 2, (July 2010): 139-146. 
Cockcroft, James D. Intellectual Precursors of the Mexican Revolution. Austin: University of Texas Press, 1968.

Cockcroft, James D. Mexico's Hope. An Encounter with Politics and History. New York: Monthly Review Press, 1998.

Collier, Ruth B. The Contradictory Alliance: State-Labor Relations and Regime Change in Mexico. Berkeley: International and Area Studies, University of California, Berkeley, 1992.

Collier, Simon, and William R. Sater. A History of Chile, 1808-1994. Cambridge: Cambridge University Press, 1996.

Concheira Bórquez, Elvira. El gran acuerdo: gobierno y empresarios en la modernización salinista. México, D.F.: Ediciones Era, 1996.

Concheira, Elvira, Antonio Gutierrez, and Juan Manuel Fragosa. El poder de la gran burgesia. México, D.F.: Ediciones de Cultura Popular, 1979.

Conniff, Michael L., ed. Populism in Latin America. Tuscaloosa: University of Alabama, 1999.

Contreras, Oscar F. and Miguel Angel Ramírez Sánchez. "La Disputa por la Flexibilidad Laboral: El Caso de Cananea." El Colegio de México Boletin Editorial 45 (1992): 11-19.

Contreras Montellano, Oscar F. La minería en Sonora: modernización industrial y fuerza de trabajo. México, D.F.: Área de Estudios sobre Historia y Sociedad-El Colegio de Sonora, 1986.

Contreras Montellano, Oscar F., ed. Cananea: tradición y modernidad en una mina histórica. México, D.F.: Colegio de Sonora, 1998.

Cordera, Rolando, Raúl Trejo Delarbre, and Juan Enrique Vega. México--el reclamo democrático: homenaje a Carlos Pereyra. México, D.F.: Siglo Veintiuno Editores, 1988.

Cordero, Salvador, and Rafael Santín. Los grupos industriales: Una nueva organización económica en México. México, D.F.: Colegio de México, 1977.

Corneja Murrieta, Gerardo, ed. Historia General de Sonora V: Historia Contemporánea de Sonora, 1929-1984. Hermosillo: Gobierno del Estado de Sonora, 1985. 
Coronil, Fernando. "Foreword." In Close Encounters of Empire: Writing the Cultural History of U.S.-Latin American Relations. Edited by Gilbert M. Joseph, Catherine C. Le Grand, and Ricardo D. Salvatore. ix-xii. Durham and London: Duke University Press, 1998.

Coronil, Fernando. The Magical State: Nature, Money, and Modernity in Venezuela. Chicago: University of Chicago Press, 1997.

Cosio Villegas, Daniel. Historia moderna de México. México, D.F.: Editorial Hermes, 1955.

Costa, Emília Viotti da. The Brazilian Empire: Myths and Histories. Chicago: University of Chicago, 1985.

Cronon, William. Nature's Metropolis: Chicago and the Great West. New York: W.W. Norton, 1991.

Cypher, James M. State and Capital in Mexico: Development Policy Since 1940. Boulder, Colo.: Westview Press, 1990.

Cypher, James, and Raúl Delgado Wise. Mexico's Economic Dilemma: The Developmental Failure of Neoliberalism: A Contemporary Case Study of the Globalization Process. Lanham: Rowman \& Littlefield Publishers, 2010.

Deans-Smith, Susan, and Gilbert M. Joseph. "The Arena of Dispute." The Hispanic American Historical Review 79, no. 2, Special Issue: Mexico's New Cultural History: Una Lucha Libre (May, 1999): 203-209.

Delgado Wise, Raúl, and Rubén Del Pozo Mendoza. "Mexicanization, Privatization, and Large Mining Capital in Mexico." Latin American Perspectives 32 , no 4 . (July 2005): 65-86.

Díaz y Díaz, Martín. "El régimen jurídico ambiental del subsuelo en México." In Pemex: ambiente y energía: los retos del futuro. 35-55. México, D.F.: Instituto de Investigaciones Jurídicas, Universidad Nacional Autónoma de México, Petróleos Mexicanos, 1995.

Dornbusch, Rudiger and Sebastian Edwards, eds. The Macroeconomics of Populism in Latin America. Chicago: University of Chicago Press, 1991.

Doyle, Don H. and Marco Antonio Pamplona, eds. Nationalism in the New World. Athens: University of Georgia Press, 2006. 
Epstein, Edward, ed. Labour Autonomy and the State in Latin America. Boston: Unwin Hyman, 1989.

Erfani, Julie A. The Paradox of the Mexican State: Rereading Sovereignty from Independence to NAFTA. Boulder, Colo.: Lynne Riener, 1995.

Escobar, Arturo. Encountering Development: The Making and Unmaking of the Third World. Princeton: Princeton University Press, 1995.

Ferry, Elizabeth E. Not Ours Alone: Patrimony, Value, and Community in Contemporary Mexico. New York: Columbia University Press, 2005.

Finn, Janet L. Tracing the Veins Of Copper, Culture, and Community from Butte to Chuquicamata. Berkeley: University of California Press, 1998.

Fischel, Anne, and Lin Nelson. "The Assault on Labor in Cananea, Mexico." Dollars and Sense, no. 290 (September/October 2010), http://dollarsandsense.org/archives/2010/0910fischelnelson.html (accessed June 7, 2016).

Fisk, Catherine L. and Robert W. Gordon, "“"'Law As. ..”: Theory and Method in Legal History." UC Irvine Law Review, no. 3 (2011): 519-542.

Fitzgerald, E. V. K. "The State and Capital Accumulation in Mexico." Journal of Latin American Studies 10, no. 2 (1978): 263-282.

Florescano, Enrique. National Narratives in Mexico: A History. Translated by Nancy T. Hancock. Norman: University of Oklahoma Press, 2006.

Foucault, Michel. "The Order of Discourse." In Untying the Text: A PostStructuralist Reader, edited by Robert Young, 51-78. Boston: Routledge, 1981.

Frazer, Chris. Bandit Nation: A History of Outlaws and Cultural Struggle in Mexico, 1810-1920. Lincoln: University of Nebraska Press, 2006.

French, William. A Peaceful and Working People: Manners, Morals, and Class Formation in Northern Mexico. Albuquerque: University of New Mexico Press, 1996.

Galindo, Magdalena. "El movimiento obrero en el sexenio echeverrista." Investigación Económica 4 (1977): 97-127.

en Gallo, Ruben. Mexican Modernity: The Avant-Garde and the Technological Revolution. Cambridge, Mass.: MIT Press, 2005. 
Gasca Zamora, J. "Fuentes para el estudio de las empresas paraestatales de México." Comercio Exterior 39, no. 2 (February 1989): 151-175.

Gauss, Susan M. Made in Mexico: Regions, Nation, and the State in the Rise of Mexican Industrialism, 1920s-1940s. University Park: Pennsylvania State University, 2010.

García Márquez, Enrique. Análisis del Sindicato Nacional de Trabajadores Mineros, Metalúrgicos y Similares de la República Mexicana (1970-1980). México, D.F.: Universidad Autónoma Metropolitana/Iztapalapa, 1989.

Garrido, Celso. "El liderazgo de las grandes empresas industriales mexicanas." In Grandes empresas y grupos industriales latinoamericanos, edited by Wilson Peres, 397-472. México, D.F.: Siglo XXI/CEPAL, 1998.

Gee, James Paul. An Introduction to Discourse Analysis: Theory and Method. 3rd Edition. New York: Routledge, Taylor and Francis, 2011.

Gillingham, Paul, and Benjamin T. Smith. "Introduction: The Paradoxes of Revolution." In Dictablanda: Politics, Work, and Culture in Mexico, 19381968, edited by Paul Gillingham and Benjamin T. Smith, 1-43. Durham: Duke University Press, 2014.

Gilly, Adolfo. The Mexican Revolution. Translated by Patrick Camiller. London: Verso Editions and NLB, 1983.

Giménez Cacho, Luis Emilio. "La fundación del sindicato minero-metalúrgico." In Minero-metalúrgicos, vol. 2, 7-38. México, D.F.: GV Editores, 1987.

Girvan, Norman. "Economic Nationalism." Daedalus 104, no. 4, The Oil Crisis: In Perspective (Fall, 1975): 145-158.

Glade, William, ed. Privatization of Public Enterprises in Latin America. San Francisco: ICS Press, 1991.

Glade, William P. and Charles W. Anderson. The Political Economy of Mexico. Madison: University of Wisconsin Press, 1968.

Gonzales, Michael J. "United States Copper Companies, the State, and Labour Conflict in Mexico, 1900-1910." Journal of Latin American Studies 26, no. 3 (October 1994): 651-681. 
Gonzales, Michael J. 'U.S. Copper Companies, the Mine Workers' Movement, and the Mexican Revolution, 1910-1920." The Hispanic American Historical Review 76, no. 3 (August 1996): 503-534.

González Gómez, Marco Antonio. La política económica neoliberal en México (1982-2000). México, D.F.: Quinto Sol, 2009.

Grandin, Greg. Empire's Workshop: Latin America, the United States, and the Rise of the New Imperialism. New York: Metropolitan Books, 2006.

Grayson, George W. The Politics of Mexican Oil. Pittsburgh: University of Pittsburgh, 1980.

Greaves, Thomas, and William Culver, eds. Miners and Mining in the Americas. Manchester: Manchester University Press, 1985.

Green, Duncan. Silent Revolutionaries: The Rise of Market Economics in Latin America. London: Casssell/Latin America Bureau, 1995.

Haber, Stephen. "Anything Goes: Mexico's "New Cultural History."' Hispanic American Historical Review 79, no. 2 (May 1999): 309-330.

Hall, Linda B. Oil, Banks, and Politics: The United States and Postrevolutionary Mexico, 1917-1924. Austin: University of Texas Press, 1995.

Hamilton, Nora. The Limits of State Autonomy: Post-Revolutionary Mexico. Princeton: Princeton University, 1982.

Hamilton, Nora. Mexico: Political, Social, and Economic Evolution. New York: Oxford University Press, 2011.

Hamnett, Brian R. A Concise History of Mexico. 2nd Edition. Cambridge: Cambridge University Press, 2006.

Hart, John M. Anarchism and the Mexican Working Class, 1860-1931. Austin: The University of Texas Press, 1978.

Hart, John. Revolutionary Mexico. The Coming and Process of the Mexican Revolution. Berkeley: University of California, 1987.

Herrera Canales, Inés, ed. La minería mexicana de la colonia al siglo XX. México, D.F.: Instituto Mora, 1998. 
Hinds, Harold E. and Charles M. Tatum. Not Just for Children: The Mexican Comic Book in the Late 1960s and 1970s. Westport, Conn.: Greenwood Press, 1992.

Hobsbawm, E.J. Nations and Nationalism Since 1780: Programme, Myth, Reality. Cambridge: Cambridge University Press, 1992.

Hobsbawm, E.J. "Introduction: Inventing Traditions." In The Invention of Tradition, edited by Eric Hobsbawm \& Terence Ranger, 1-14. Cambridge: Cambridge University Press, 1983.

Hodges, Donald C. and Ross Gandy. Mexico and the End of the Revolution. Westport, Conn.: Praeger, 2002.

Holmes, Christopher. "Introduction: A Post-Polanyian Political Economy for Our Times." Economy and Society 43, no. 4 (November 2014): 525-540.

Hoshino, Taeko. Industrialization and Private Enterprises in Mexico. Chiba: Institute of Developing Economies-Japan External Trade Organization, 2001.

Hyde, Charles. Copper for America: The United States Copper Industry from Colonial Times to the 1990s. Tucson: University of Arizona Press, 1998.

Ibarra M., Jorge Luis, José Luis Moreno V., and Leopoldo Santos R. "Cananea: Resistencias regionales a la política de modernización. Revista de El Colegio de Sonora, Rev. Col. Sonora 2, no. 2, (1990): 133-171.

Izquierdo, Rafael. Política hacendaria del desarrollo establizador, 1958-1970. México, D.F.: Colegio de México, 1995.

Jones, Geoffrey. Multinationals and Global Capitalism: From the Nineteenth to the Twenty-First Century. Oxford, New York: Oxford University Press, 2005.

Jones, Geoffrey G. and Jonathan Zeitlin. "Introduction." In The Oxford Handbook of Business History, edited by Geoffrey G. Jones and Jonathan Zeitlin. Oxford: Oxford University Press, 2010.

Joseph, Gilbert M. and Daniel Nugent eds. Everyday Forms of State Formation: Revolution and the Negotiation of Rule in Modern Mexico. Durham, NC: Duke University Press, 1994. 
Joseph, Gilbert M., and Jürgen Buchenau. Mexico's Once and Future Revolution: Social Upheaval and the Challenge of Rule since the Late Nineteenth Century. Durham: Duke University Press, 2013.

Joseph, Gilbert M. Reclaiming the Political in Latin American History: Essays from the North. Durham: Duke University Press, 2001.

Joseph, Gilbert M., Anne Rubenstein, and Eric Zolov, eds. Fragments of a Golden Age: The Politics of Culture in Mexico since 1940. Durham: Duke University Press, 2001.

Kalmo, Hent, and Quentin Skinner, eds. Sovereignty in Fragments: The Past, Present and Future of a Contested Concept. Cambridge: Cambridge University Press, 2010.

Kentor, Jeffrey. "The Growth of Transnational Corporate Networks, 1962 to 1998." Journal of World-Systems Research 11, no. 2 (2005): 262-286.

Kiddle, Amelia M. and María L.O. Muñoz. Populism in Twentieth Century Mexico: The Presidencies of Lázaro Cárdenas and Luis Echeverría. Tucson: University of Arizona Press, 2010.

Kirsch, Stuart. Mining Capitalism: The Relationship between Corporations and their Critics. Oakland: University of California Press, 2014.

Kleinberg, Remonda Bensabar. Strategic Alliances and Other Deals: StateBusiness Relations and Economic Reform in Mexico. Durham: Carolina Academic Press, 1999.

Klubock, Thomas. Contested Communities: Class, Gender, and Politics in Chile's El Teniente Copper Mine, 1904-1951. Durham: Duke University Press, 1998.

Knight, Alan. The Mexican Revolution. 2 volumes. Lincoln: University of Nebraska Press, 1986.

Knight, Alan. "The Myth of the Mexican Revolution." Past and Present, no. 209 (Nov. 2010): 223-273.

Knight, Alan. "Peasants into Patriots: Thoughts on the Making of the Mexican Nation." Mexican Studies/Estudios Mexicanos 10, no. 1 (Winter 1994): 135-161. 
Koppes, Clayton R. "The Good Neighbor Policy and the Nationalization of Mexican Oil: A Reinterpretation." The Journal of American History 69, no. 1 (Jun., 1982): 62-81.

Labastida, Julio, ed. Grupos económicos y organizaciones empresariales en México." México, D.F.: Biblioteca Iberoamericana, Alianza Mexicana, UNAM, 1986.

La Botz, Dan. The Crisis of Mexican Labor. New York: Praeger, 1992.

Levy, Daniel, and Gabriel Székely. Mexico: Paradoxes of Stability and Change. Boulder, Colo.: Westview Press, 1987.

Lomnitz, Claudio. Deep Mexico, Silent Mexico: An Anthropology of Nationalism. Minneapolis: University of Minnesota Press, 2002.

López González, Pedro. Un precursor social llamado: Esteban Baca Calderón. México: Comunicación Optima, 2008.

Lustig, Nora. Mexico: The Remaking of an Economy. Washington, DC: The Brookings Institution, 1992.

MacKenzie, Donald. Material Markets: How Economic Agents Are Constructed. Oxford: Oxford University Press, 2009.

MacKenzie, Donald, Daniel Beunza, Yuval Millo, and Juan Pablo PardoGuerra. "Drilling Through The Allegheny Mountains: Liquidity, Materiality and High-Frequency Trading." Journal of Cultural Economy 5, no. 3, (August 2012): 279-296.

MacKenzie, Donald, Fabian Muniesa, and Lucia Siu, eds. Do Economists Make Markets? On the Performativity of Economics. Princeton: Princeton University Press, 2007.

MacLeod, Dag. Downsizing the State: Privatization and the Limits of Neoliberal Reform in Mexico. University Park: Pennsylvania State University Press, 2004.

Magdoff, Henry. The Age of Imperialism: The Economics of U.S. Foreign Policy. New York: Monthly Review Press, 1969.

Marcosson, Isaac. Anaconda. New York: Dodd, Mead, 1976. 
Marichal, Carlos. "Banking History and Archives in Latin America." The Business History Review 82, no. 3, A Special Issue on Business in Latin America (Autumn, 2008): 585-602.

Maurer, Noel. "The Empire Struck Back: Sanctions and Compensation in the Mexican Oil Expropriation of 1938." The Journal of Economic History 71, no. 3 (September 2011).

Maxfield, Sylvia, and Ricardo Anzadúa Montoya, eds. Government and Private Sector in Contemporary Mexico. La Jolla: Center for U.S.-Mexican Studies, University of California, San Diego, 1987.

McCaffery, Peter Gabriel, and Ben Marsden, eds. The Cultural History Reader. London: Routledge, 2014.

Meyer, Lorenzo. Mexico and the United States in the Oil Controversy, 19161942. Austin: University of Texas Press, 1977.

Mezger, Dorothea. Copper in the World Economy. Translated by Pete Burgess. New York and London: Monthly Review, 1980.

Middlebrook, Kevin J. The Paradox of Revolution: Labor, the State, and Authoritarianism in Mexico. Baltimore: John Hopkins University Press, 1995.

Middlebrook, Kevin, ed. Unions, Workers, and the State in Mexico. La Jolla: Center for U.S.-Mexican Studies, University of California, San Diego.

Millán, René. Los empresarios ante el estado y la sociedad. México, D.F.: Siglo Veintiuno, 1988.

Miller, Rory. "Latin American Business History and Varieties of Capitalism." Business History Review 84, no. 4 (Winter, 2010): 653-657.

Mills, Sara. Discourse. London: Routledge, 2004.

Mora, Felipe, and Victor Manuel Reynoso. Modernización legislacion laboral en el noreste de México. Hermosillo: El Colegio de Sonora, 1990.

Morales Tapia, Jesús. Los campos mineros de Cananea. México, D.F.: Compañía Minera de Cananea, 1985.

Moreira Camacho, Carlos. El capital financiero en México y la globalizacion: Limites y contradicciones. México, D.F.: ERA/IIE/UNAM, 1998. 
Moreno, Julio. Yankee Don't Go Home! Mexican Nationalism, American Business Culture, and the Shaping of Modern Mexico, 1920-1950. Chapel Hill:

University of North Carolina Press, 2003.

Moreno-Brid, Juan Carlos, and Jaime Ros. Development and Growth in the Mexican Economy: A Historical Perspective. Oxford: Oxford University Press, 2009.

Morineau, Oscar. Los derechos reales y el subsuelo en Mexico. México, D.F.: Fondo de Cultura Económica, 1948.

Morris, Stephen D. "Reforming the Nation: Mexican Nationalism in Context." Journal of Latin American Studies 31, No. 2 (May, 1999): 363-397.

Morton, Adam D. Revolution and State in Modern Mexico: The Political Economy of Uneven Development. Lanham, MD: Rowman and Littlefield Publishers, 2011.

Morton, Paula E. Tortillas: A Cultural History. Albuquerque: University of New Mexico Press, 2014.

Mosk, Sanford A. Industrial Revolution in Mexico. Berkeley: University of California Press, 1950.

Nacional Financiera, Medio Sigo de Banca de Desarrollo. Testimonio de sus Directores Generales. México, D.F.: Nacional Financiera, 1985.

Nash, June. We Eat the Mines and the Mines Eat Us: Dependency and Exploitation in Bolivian Tin Mines. New York: Columbia University Press, 1979.

Navin, Thomas R. Copper Mining and Management. Tuscon: University of Arizona Press, 1978.

Noriega Elio, Cecilia, ed. El nacionalismo en México. Michoacán: El Colegio de Michoacán, 1992.

O'Brien, Thomas. The Century of U.S. Capitalism in Latin America. Albuquerque: University of New Mexico Press, 1999.

O'Brien, Thomas. The Revolutionary Mission: American Enterprise in Latin America, 1900-1945. Cambridge: Cambridge University Press, 1999. 
O'Malley, Irene V. The Myth of the Revolution: Hero Cults and the Institutionalization of the Mexican State, 1920-1940. New York: Greenwood Press, 1986.

Otero, Gerardo, ed. Mexico in Transition: Neoliberal Globalism, the State, and Civil Society. London: Zed Books, 2004.

Otis, Margarita. La ratonera: comentarios sobre Compañía Minera de la Cananea, 1971-1989. Cananea: Paula Publishers, 1990.

O'Toole, Gavin. The Reinvention of Mexico: National Ideology in a Neoliberal Era. Liverpool: Liverpool University Press, 2010.

Pavilack, Jody. Mining for the Nation: The Politics of Chile's Coal Communities From the Popular Front to the Cold War. University Park: Pennsylvania State University, 1991.

Perzabal, Carlos. Acumulación capitalista dependiente y subordinada. El caso de México, 1940-1978. México, D.F.: Siglo XXI, 1979.

Petras, James and Henry Veltmeyer. Globalization Unmasked: Imperialism in the 21st Century. Toronto: Zed Books/Fernwood Publishing Company, 2001.

Petras, James F., Henry Veltmeyer, and Daniel Azpiazu. Las privatizaciones y la desnacionalización de América Latina. Buenos Aires: Prometeo Libros, 2004.

Piccato, Pablo. City of Suspects: Crime in Mexico City, 1900-1931. Durham: Duke University Press, 2001.

Pletcher, David M. Rails, Mines, and Progress: Seven American Promoters in Mexico, 1867-1911. Ithaca: Cornell University Press, 1958.

Polanyi, Karl. The Great Transformation. Boston: Beacon Press, 1957.

Poster, M. Cultural History and Postmodernity: Disciplinary Readings and Challenges. New York: Columbia University Press, 1997.

Przeworksi, Joanne F. The Decline of the Copper Industry in Chile and the Entrance of North American Capital, 1870-1916. New York: Arno Press, 1980.

Ramírez, Miguel D. Development Banking in Mexico: The Case of the Nacional Financiera, S.A. Wesport, Conn.: Praeger, 1986. 
Ramírez, Miguel D. Mexico's Economic Crisis: Its Origins and Consequences. Wesport, Conn.: Praeger, 1986.

Ramírez Sánchez, Miguel Ángel. Trabajo y relaciones laborales en una transición prolongada el caso de Mexicana de Cananea, antes Compañia Minera de Cananea. Hermosillo: M. A. Ramírez Sánchez, 1996.

Randall, Robert W. "Mexico's Pre-Revolutionary Reckoning with Railroads." The Americas 42, no. 1 (Jul., 1985): 1-28.

Reber, Vera. "Archival Sources for Latin American Business History." The Business History Review 59, no. 4, Business in Latin America (Winter, 1985): 670-679.

Reygadas, Luis. Proceso de trabajo y acción obrera: historia sindical de los mineros de Nueva Rosita, 1929-1979. México D.F.: Instituto Nacional de Antropología e Historia, Escuela Nacional de Antropología e Historia, 1988.

Rey Romay, Benito. La ofensiva empresarial contra la intervención del estado. México, D.F.: Siglo Veintiuno, 1984.

Rivera Ríos, Miguel A., and Pedro Gómez Sánchez. "México: Acumulación de capital y crisis en la década del setenta." Teoría y Política 1, no. 2 (October-December 1980): 73-120.

Robinson, William I. Latin America and Global Capitalism: A Critical Globalization Perspective. Baltimore: Johns Hopkins University Press, 2008.

Rogozinsky, J. La Privatización de Empresas Paraestatales: Una Visión de la Modernización. México, D.F.: Fondo de Cultura Económica, 1996.

Romero Gil, Juan Manuel. La minería en el noroeste de México: utopía y realidad, 1850-1910. México: Universidad de Sonora, Plaza y Valdés Editores, 2001.

Rosenberg, Emily. Financial Missionaries: The Politics and Culture of Dollar Diplomacy, 1900-1930. Cambridge, Mass.: Harvard University Press, 1999.

Roxborough, lan. Unions and Politics in Mexico: The Case of the Automobile Industry. Cambridge: Cambridge University Press, 1984. 
Ruiz de Moreno, Norma Yolanda. Derecho minero: historia y procedimientos. Hermosillo, Son.: N.Y. Ruiz de Moreno, 1999.

Ruiz, Ramón Eduardo. Labor and the Ambivalent Revolutionaries: Mexico, 19111923. Baltimore: Johns Hopkins University Press, 1976.

Ruiz, Ramon Eduardo. Mexico: Why a Few are Rich and the People Poor. Berkeley: University of California Press, 2010.

Ruiz, Ramón Eduardo. The People of Sonora and Yankee Capitalists. Tuscon: University of Arizona Press, 1988.

Salas, Carlos. "Social Structures of Accumulation and the Condition of the Working Class in Mexico." In Contemporary Capitalism and Its Crises: Social Structure of Accumulation Theory for the 21st Century, edited by Terrence McDonough, Michal Reich, David M. Kotz, 286-308. Cambridge, Cambridge University Press, 2010.

Sallaz, Jeffrey J. Labor, Economy, and Society. Cambridge, U.K.: Polity Press, 2013.

Salvatore, Ricardo. "The Normalization of Economic Life: Representations of the Economy in Golden Age Buenos Aires, 1890-1913." Hispanic American Historical Review 81, no. 1 (February 2001): 1-44.

Sanchez, Manuel, and Rossana Corona, eds. Privatization in Latin America. Washington, D.C.: Inter-American Development Bank, 1993.

Santiago, Myrna I. The Ecology of Oil: Environment, Labor, and the Mexican Revolution, 1900-1938. Cambridge: Cambridge University Press, 2006,.

Sariego, Juan Luis. Enclaves y minerales en el norte de México. Historia social de los mineros de Cananea y Nueva Rosita, 1900-1970. México, D.F.: Ediciones de la Casa Chata, 1988.

Sariego, Juan Luis, Luis Reygadas, Miguel Ángel Gómez, and Javier Farrera. El estado y la minería mexicana: política, trabajo y sociedad durante el siglo xx. México, D.F.: Fondo de Cultura Económica, 1988.

Sariego, Juan Luis, and Raúl Santana Paucar. "Transición tecnológica y resistencia obrera en la minería mexicana." Cuadernos Políticos 31 (January - March 1982): 17-27.

Sariego, Juan Luis. "La interminable huelga de los mineros mexicanos de Cananea:¿El final de un régimen laboral?," Amérique Latine Histoire 
et Mémoire 26 (December 2013),

https://journals.openedition.org/alhim/4789\#text (accessed November 7, 2017).

Sariego, J.L. "La reconversion industrial en la mineria cananense." Nueva Antropología 9, no. 32 (1987): 9-24.

Schell, Jr. William. "Emiliano Zapata and the Old Regime: Myth, Memory, and Method." Mexican Studies/Estudios Mexicanos 25, no. 2 (Summer 2009): 327-365.

Schlefer, Jonathan. Palace Politics: How the Ruling Party Brought Crisis to Mexico. Austin: University of Texas Press, 2008.

Schmidt, Henry C. The Roots of Lo Mexicano: Self and Society in Mexican Thought, 1900-1934. College Station: Texas A\&M University Press, 1978.

Sepúlveda Amor, Bernardo, Olga Pellicer de Brody, and Lorenzo Meyer. Las Empresas Transnacionales en México." México, D.F.: Colegio de México, 1974.

Serrano, Mónica, ed. Mexico: Assessing Neo-Liberal Reform. London: Institute of Latin American Studies, 1997.

Servin, Elisa, ed. Del nacionalismo al neoliberalismo, 1940-1994. México, D.F.: Fondo de Cultura Económica, 2010.

Sewell, William. Logics of History: Social Theory and Social Transformation. Chicago: University of Chicago, 2005.

Sherman, John. The Mexican Right: The End of Revolutionary Reform. Westport, Conn.: Praeger, 1997.

Sigmund, P. E. Multinationals in Latin America: The Politics of Nationalization. Madison: University of Wisconsin Press, 1980.

Silva Rodriguez, Juan Manuel. "Mineros y Minerales en Crisis: La Lucha Continúa. Miradas al Sujeto Histórico en las Huelgas de Cananea, Sonora, 1906-2007." Ph.D. diss., Centro de Investigaciones y Estudios Superiores en Antropología Social, 2011.

Sklair, Leslie. The Transnational Capitalist Class. Oxford: Blackwell Publishers, 2001. 
Sklansky. Jeffrey. "The Elusive Sovereign: New Intellectual and Social Histories of Capitalism," Modern Intellectual History 9, no. 1 (April 2012): 242. (233248.

Smith, Peter H. "Mexico since 1946: Dynamics of an Authoritarian Regime," in Mexico since Independence, edited by Leslie Bethell, 321-396. Cambridge: Cambridge University Press, 1991.

Smith, Robert F. The United States and Revolutionary Nationalism in Mexico, 1916-1932. Chicago: University of Chicago Press, 1972.

Smith, David A., Dorothy J. Solinger, and Steven C. Topik. States and Sovereignty in the Global Economy. London: Routledge, 2002.

Socolow, Susan Migden. "Putting the "Cult" in Culture." Hispanic American Historical Review 79, no. 2 (May 1999):

Sonnichsen, Charles L. Colonel Greene and the Copper Skyrocket : The Spectacular Rise and Fall of William Cornell Greene Copper King, Cattle Baron and Promoter. N.p.: Arcadia Publishing, 1974.

Sotelo Valencia, Adrián. México (Re)cargado: Dependencia, neoliberalismo y crisis. México, D.F.: UNAM, 2014.

Spalding, Hobart J. Organized Labor in Latin America. New York: New York University Press, 1977.

Story, Dale. Industry, the State, and Public Policy in Mexico. Austin: University of Texas Press, 1986.

Story, Dale. The Mexican Ruling Party: Stability and Authority. New York: Praeger, 1986.

Szmrecsanyi, Tamás, and Steven Topik. "Business History in Latin America." Enterprise \& Society 5, no. 2 (June 2004): 179-186.

Thorp, Rosemary. Progress, Poverty, and Exclusion: An Economic History of Latin America in the Twentieth Century. Washington, DC: Inter-American Development Bank, 1998.

Tidball, Eugene C. "What Ever Happened to the Anaconda Company?" Montana 47, no. 2 (1997): 60-68.

Tomlins, Christopher, and John Comaroff. "“Law As. ..": Theory and Practice in Legal History." UC Irvine Law Review, no. 3 (2011): 1039-1079. 
Turner, Frederick C. The Dynamic of Mexican Nationalism. Chapel Hill: University of North Carolina Press, 1968.

van der Pijl, Kees. "The History of Class Struggle: From Original Accumulation to Neoliberalism." Monthly Review 49, no. 1 (1997): 28-44.

van der Pijl, Kees. "Capital and the State System: A Class Act." Cambridge Review of International Affairs 20, no. 4 (December 2007):

Van Young, Eric. "The New Cultural History Comes to Old Mexico." Hispanic American Historical Review 79, no. 2 (May 1999): 211-247.

Van Young, Eric. The Other Rebellion: Popular Violence, Ideology, and the Mexican Struggle for Independence, 1810-1821. Stanford: Stanford University Press, 2001.

Vaughn, Mary Kay, and Stephen Lewis, eds. The Eagle and the Virgin: Nation and Cultural Revolution in Mexico, 1920-1940. Durham: Duke University Press, 2005.

Verdery, Katherine. The Vanishing Hectare: Property and Value in Postsocialist Transylvania. Ithaca: Cornell University Press, 2003.

Vergara, Angela. Copper Workers, International Business, and Domestic Politics in Cold War Chile. University Park: Pennsylvania State University, 2008.

Vernon, Raymond. The Dilemma of Mexico's Development: The Roles of the Private and Public Sectors. Cambridge, Mass.: Harvard University Press, 1963.

Vidal. G. Grandes empresas, economía y poder en México. México, D.F.: Plaza y Valdes and UNAM, 2000.

Villa M., Rosa Olivia. Nacional Financiera: Banco de fomento del desarrollo económica de México. México, D.F.: Nacional Financiera, 1976.

Wallace Hall, Robert B. La dinámica del sector minero en México, 1877-1970. México, D.F.: El Colegio de México, 1972.

Weaver, Thomas, James B. Greenberg, William L. Alexander, and Anne Browning-Aiken, eds. Neoliberalism and Commodity Production in Mexico. Boulder, Colo.: University Press of Colorado, 2012. 
Whitacker, Arthur P. and David C. Jordan. Nationalism in Contemporary Latin America. New York: Free Press, 1966.

Whiting, Van R. The Political Economy of Foreign Investment in Mexico: Nationalism, Liberalism, and Constraints on Choice. Baltimore: Johns Hopkins University Press, 1992.

Wilkins, Mira. The Emergence of Multinational Enterprise: American Business Abroad from the Colonial Era to 1914. Cambridge, Mass.: Harvard University Press, 1970.

Wilkins, Mira. The Maturing of Multinational Enterprise: American Business Abroad from 1914 to 1970. Cambridge, Mass.: Harvard University Press, 1974.

Williams, Mark Eric. Market Reforms in Mexico: Coalitions, Institutions, and the Politics of Policy Change. Lanham, Md: Rowman \& Littlefield Publishers, 2001.

Woog, Carlos Arriol. Los empresarios y el estado, 1970-1982. México: Miguel Angel Porrúa, 1988.

Wright, Winthrop R. British-owned Railways in Argentina: Their Effect on Economic Nationalism, 1854-1948. Austin: University of Texas Press, 1974.

Zakim, Michael and Gary J. Kornblith. "Introduction." In Capitalism Takes Command: The Social Transformation of Nineteenth-Century America, edited by Michael Zakim and Gary J. Kornblith, 1-12. Chicago: University of Chicago Press, 2012).

Zapata, Francisco. Tiempos neoliberales en México. México: Colegio de México, 2005. 


\section{VITA \\ DOYLE L. PERDUE \\ Born in San Antonio, Texas}

ACADEMIC HISTORY

2003-2008

B.A. History, Spanish

Appalachian State University

Boone, North Carolina

2009-2011

M.A. History

University of North Carolina at Wilmington

Wilmington, North Carolina

2012-2017

Graduate Teaching Assistant

Florida International University

Miami, Florida

\section{PUBLICATIONS AND PRESENTATIONS}

Paper Presentation, "Extracting Nature: Perceptions of the Environment in Land, Labor, and Law in Cananea, Mexico, 1960-1990," Florida International University Graduate Student Conference (April 4, 2014).

Cashman Award, Best MA Thesis, "Subversion of the Revolutionary Impulse: The Influence of Recuperation on the Situationist International, 19571972," University of North Carolina at Wilmington (May 2012). 